\title{
LAND USE AND WATER USE IN THE ANTELOPE VALLEY, CALIFORNIA
}

By WILLIAM E. TEMPLIN, STEVEN P. PHILLIPS, DANIEL E. CHERRY, MYRNA L. DEBORTOLI, and OTHERS

U.S. GEOLOGICAL SURVEY

WATER-RESOURCES INVESTIGATIONS REPORT 94-4208

Prepared in cooperation with the

ANTELOPE VALLEY WATER GROUP

$$
\frac{\text { ำ }}{\stackrel{N}{N}}
$$




\title{
U.S. DEPARTMENT OF THE INTERIOR BRUCE BABBITT, Secretary
}

\author{
U.S. GEOLOGICAL SURVEY \\ GORDON P. EATON, Director
}

Any use of trade, product, or firm names in this publication is for descriptive purposes only and does not imply endorsement by the U.S. Government.

For sale by the U.S. Geological Survey

Earth Science Information Center

Open-File Reports Section

Box 25286, MS 517

Denver Federal Center

Denver, CO 80225

For additional information write to:

District Chief

U.S. Geological Survey

Federal Building, Room W-2233

2800 Cottage Way

Sacramento, CA 95825 


\section{CONTENTS}

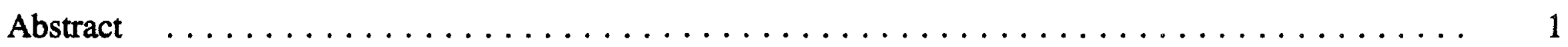

Introduction $\ldots \ldots \ldots \ldots \ldots \ldots \ldots \ldots \ldots \ldots \ldots \ldots \ldots \ldots \ldots \ldots \ldots \ldots \ldots \ldots \ldots \ldots, 1$

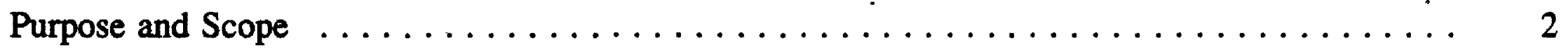

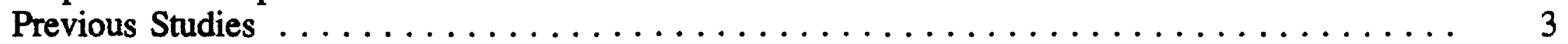

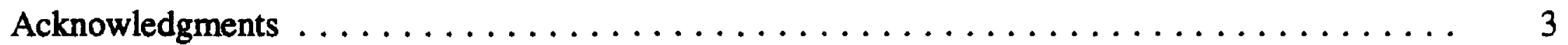

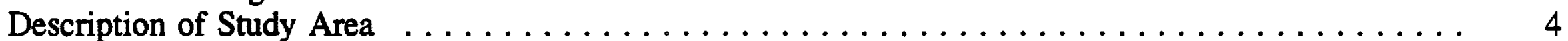

Land Use by Templin W.E., Cherry, D.E., Haltom, T.C., and McPherson, K.R. . . . . . . . . 6

Land-Use Classification for National Resource Appraisal, U.S. Geological Survey . . . . . . . . 10

Land-Use Classification for Statewide Planning, California Department of Water Resources . . . 10

Land-Use Classification for Documenting Changes of Prime Farmland to Urban Use,

California Department of Conservation, Farmland Mapping Program ............ 12

Land-use Classification for Regional Planning, Los Angeles County Department of

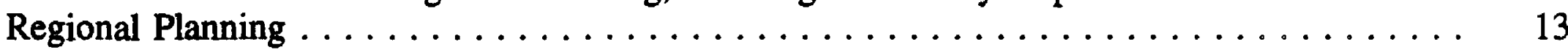

Water Use by Templin, W.E., Cherry, D.E., Phillips, S.P., and Haltom, T.C. . . . . . . . . . . 14

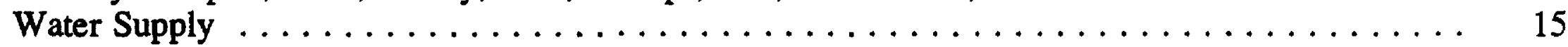

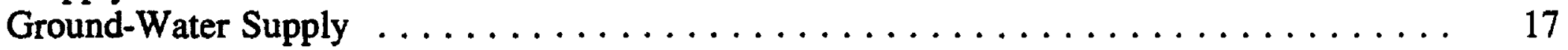

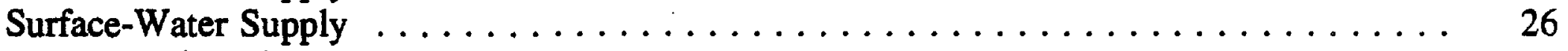

Local Surface-Water Resources $\ldots \ldots \ldots \ldots \ldots \ldots \ldots \ldots \ldots \ldots \ldots \ldots \ldots \ldots \ldots, 26$

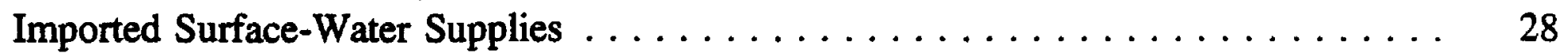

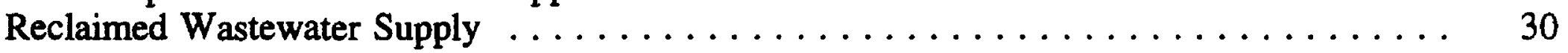

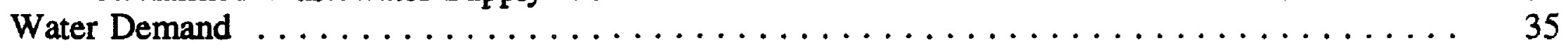

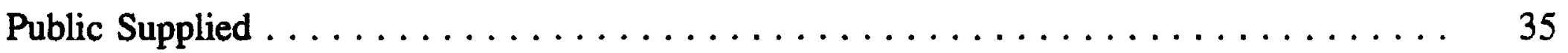

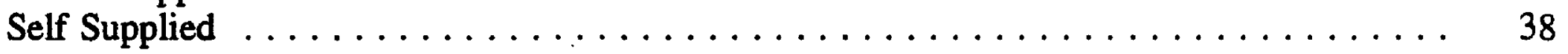

Water-Demand Forecasts by Templin, W.E., Mrozek, C.A., and Phillips, S.P. . . . . . . . 40

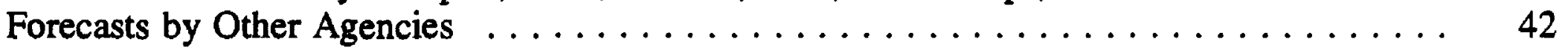

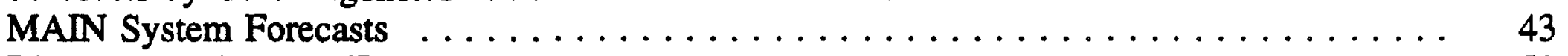

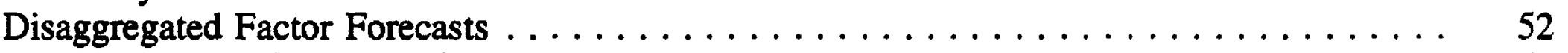

Forecasts for Military Installations $\ldots \ldots \ldots \ldots \ldots \ldots \ldots \ldots \ldots \ldots \ldots \ldots \ldots \ldots \ldots \ldots \ldots \ldots$

Data-Base Development and Annual Update Procedure $\ldots \ldots \ldots \ldots \ldots \ldots \ldots \ldots \ldots \ldots, 62$

Water-Resources Management Considerations $\ldots \ldots \ldots \ldots \ldots \ldots \ldots \ldots \ldots \ldots \ldots, 63$

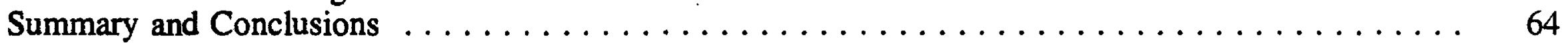

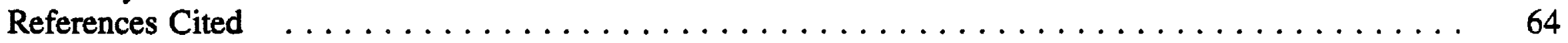

\section{FIGURES}

1. Map showing location of the Antelope Valley, California $\ldots \ldots \ldots \ldots \ldots \ldots \ldots \ldots$

2. Graph showing annual precipitation for the Leona Valley, Palmdale, and
Lancaster in the Antelope Valley $\ldots \ldots \ldots \ldots \ldots \ldots \ldots \ldots \ldots \ldots \ldots \ldots$

3. Graph showing population trends and projections for the Antelope Valley, 1960-2020 . . . . 6

4. Map showing land use in the Antelope Valley, $1973-77 \ldots \ldots \ldots \ldots \ldots \ldots \ldots . \ldots . \ldots . \ldots$

5. Map showing land use by crop type in the Antelope Valley for 1987 and $1992 \ldots \ldots \ldots \ldots \ldots 10$

6. Graph showing surveyed, estimated, and projected land use for irrigated acreage for

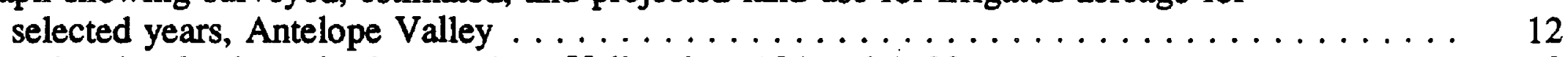

7. Map showing land use in the Antelope Valley for 1984 and $1990 \ldots \ldots \ldots \ldots \ldots \ldots \ldots$

8. Graph showing total water supplies for the Antelope Valley for 1947-91 from the data base developed for this study

9. Graph showing historical published estimates of ground-water pumpage for the Antelope Valley 
10. Graph showing ground-water pumpage from data base developed for this

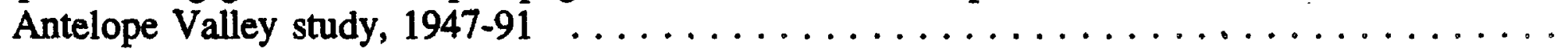

11. Map showing locations of wells in the Antelope Valley . . . . . . . . . . . . . . . . . . . 25

12. Map showing water-district boundaries in the Antelope Valley . . . . . . . . . . . . . 27

13. Graph showing surface-water diversions in Antelope Valley reported to the California State Water Resources Control Board, Division of Water Rights, 1947-91 . . . . . . . . . . . . 28

14. Map showing locations of surface-water reservoirs and other selected water bodies in the Antelope Valley

15-19. Graphs showing:

15. Imported water supplies for the Antelope Valley $\ldots \ldots \ldots \ldots \ldots \ldots \ldots \ldots \ldots \ldots$

16. Wastewater influent and reuse in the Antelope Valley ................. 33

17. Annual withdrawals, by source, and seasonal water deliveries, by month, to meet demands for the Palmdale Water District . . . . . . . . . . . . . . . .

18. Historical and predicted alfalfa acreages and historical electrical costs in the Antelope Valley . . . . . . . . . . . . . . . . . . . . . . . . .

19. Water-demand projections for the Antelope Valley made in 1980 and 1990 to the year 2020

1. Irrigated and nonirrigated land use by year and crop type $\ldots \ldots \ldots \ldots \ldots \ldots \ldots$

2. Water supplies and demands in the Antelope Valley, with historical and recent projections to 2020

3. Selected water-use information by water supplier and water-supply sources summarized from data bases created for Antelope Valley, 1989-91

4. Estimates of annual ground-water pumpage in the Antelope Valley, 1919-91

5. Capacities and locations of surface-water reservoirs in the Antelope Valley

6. Entitlements and actual deliveries of water imported to the Antelope Valley from the

California Aqueduct

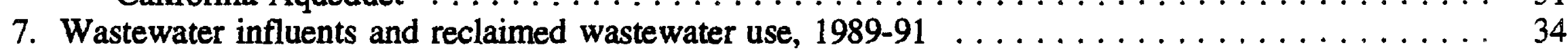

8. Public-supplied and self-supplied water demands in Antelope Valley by water supplier and source, 1989-91

9. Irrigation water use and irrigated acreage in the Antelope Valley, $1989 \ldots \ldots \ldots \ldots \ldots \ldots$

10. Data requirements for the MWD_MAIN base year 1980 .

11. Data requirements by forecast method for MWD_MAIN forecast years 1984, 1987, 1990, 2000, and 2010 for Lancaster and Palmdale . . . . . . . . . . . . . . . . . . . .

12. Water-demand forecast for the Antelope Valley and the cities of Lancaster and Palmdale,

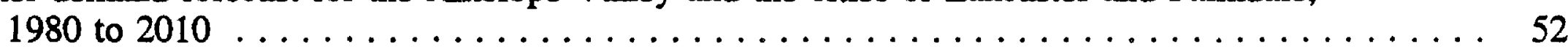

13. Employment data for the Antelope Valley by Standard Industrial Code $\ldots \ldots \ldots \ldots \ldots \ldots$

14. Median income distribution for the Antelope Valley $\ldots \ldots \ldots \ldots \ldots \ldots \ldots \ldots \ldots \ldots$

15. Housing statistics for single-family housing in the Antelope Valley . . . . . . . . . . . 59

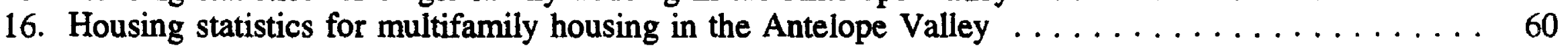

17. Antelope Valley population projections as reported by various agencies . . . . . . . . . . 61

18. Water-use information for public water suppliers in Antelope Valley by water-supply

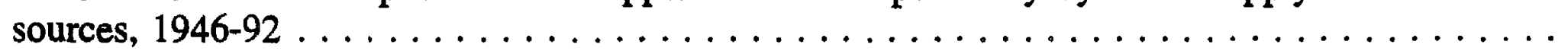

19. Water-use information for self-supplied water users in Antelope Valley by water-supply sources, $1946-92$ 


\section{CONVERSION FACTORS AND VERTICAL DATUM}

\section{Conversion Factors}

\begin{tabular}{rcl}
\hline Multiply & \multicolumn{1}{c}{ By } & To obtain \\
acre & 0.4047 & hectare \\
acre-foot (acre-ft) & 1,234 & cubic meter \\
acre-foot per year (acre-ft/yr) & 1,234 & cubic meter per year \\
acre-foot per acre (acre-ft/acre) & 3,048 & cubic meter per hectare \\
foot (ft) & 0.3048 & meter \\
gallon (gal) & 3.785 & liter \\
gallon per day (gal/d) & 0.003785 & cubic meter per day \\
inch (in.) & 25.4 & millimeter \\
inch per year (in/yr) & 25.4 & millimeter per year \\
mile (mi) & 1.609 & kilometer \\
square mile (mi $\left.{ }^{2}\right)$ & 259.0 & hectare \\
& 2.590 & square kilometer \\
\hline
\end{tabular}

Temperature is given in degrees Fahrenheit $\left({ }^{\circ} \mathrm{F}\right)$, which can be converted to degrees Celsius $\left({ }^{\circ} \mathrm{C}\right)$ by the following equation:

$$
\text { Temp }{ }^{\circ} \mathrm{C}=5 / 9\left({ }^{\circ} \mathrm{F}\right)-32 \text {. }
$$

\section{Vertical Datum}

Sea level: In this report, "sea level" refers to the National Geodetic Vertical Datum of 1929-a geodetic datum derived from a general adjustment of the first-order level nets of the United States and Canada, formerly called Sea Level Datum of 1929. 


\title{
LAND USE AND WATER USE IN THE
}

\section{ANTELOPE VALLEY, CALIFORNIA}

\author{
By William E. Templin, Steven P. Phillips, Daniel E. Cherry, Myrna L. DeBortoli, and others
}

\section{Abstract}

Urban land use and water use in the Antelope Valley, California, have increased significantly since development of the valley began in the late 1800 's. Ground water has been a major source of water in this area because of limited local surface-water resources. Ground-water pumpage is reported to have increased from about 29,000 acre-feet in 1919 to about 400,000 acre-feet in the 1950's. Completion of the California Aqueduct to this area in the early 1970's conveyed water from the Sacramento-San Joaquin Delta, about 400 miles to the north. Declines in groundwater levels and increased costs of electrical power in the 1970's resulted in a reduction in the quantity of ground water that was pumped annually for irrigation uses. Total annual reported ground-water pumpage decreased to a low of about 53,200 acre-feet in 1983 and increased to about 91,700 acre-feet in 1991 as a result of rapid urban development and the 1987-92 drought. This increased urban development, in combination with several years of drought, renewed concern about a possible return to extensive depletion of ground-water storage and increased land subsidence.

Increased water demands are expected to continue as a result of increased urban development. Water-demand forecasts in 1980 for the Antelope Valley indicated that total annual water demand by 2020 was expected to be about 250,000 acre-feet, with agricultural demand being about 65 percent of this total. In 1990 , total water demand was projected to be about 175,000 acre-feet by 2010; however, agricultural water demand was expected to account for only 37 percent of the total demand. New and existing land- and water-use data were collected and compiled during
1992-93 to identify present and historical land and water uses. In 1993, preliminary forecasts for total water demand by 2010 ranged from about 127,500 to 329,000 acre-feet. These wide-ranging estimates indicate that forecasts can change with time as factors that affect water demand change and different forecasting methods are used. The forecasts using the MWD_MAIN (Metropolitan Water District of Southern California Municipal and Industrial Needs) water-demand forecasting system yielded the largest estimates of water demand. These forecasts were based on projections of population growth and other socioeconomic variables. Initial forecasts using the MWD_MAIN forecasting system commonly are considered "interim" or preliminary. Available historical and future socioeconomic data required for the forecasting system are limited for this area. Decisions on local water-resources demand management may be made by members of the Antelope Valley Water Group and other interested parties based on this report, other studies, their best judgement, and cumulative knowledge of local conditions. Potential water-resource management actions in the Antelope Valley include (1) increasing artificial ground-water recharge when excess local runoff (or imported water supplies) are available; (2) implementing water-conservation best-management practices; and (3) optimizing ground-water pumpage throughout the basin.

\section{INTRODUCTION}

Reported water use in the part of Antelope Valley in Los Angeles County, California, peaked in 1956, when agriculture was the primary water use and ground water the primary water source. Historical pumpage data for the part of Kern 
County in Antelope Valley is severely limited, but we can assume a similar peak for the entire Antelope Valley. Rapid ground-water-level declines and associated land subsidence were consequences of extensive ground-water use. In the 1970's, increased pumping lifts because of declining ground-water levels and increased electrical costs resulted in decreases in irrigated agriculture and related agricultural water use. The decrease in irrigated agriculture and the importation of surface water to the Antelope Valley have reduced demands on local ground-water supplies to about one-third of the demand that existed 40 years ago. However, increased stress is again being placed on local ground-water resources by continued concentration of pumping in expanding urban areas and several consecutive years of drought. Information on rainfall and runoff and estimates of ground-water recharge indicate that more water continues to be pumped annually than replenishes the ground-water resource.

In 1992, the sixth year of drought, concern about the consequences of long-term declines in ground-water levels, present and future availability of surface-water, and the potential for additional land-subsidence-related damages resulted in a cooperative agreement between the U.S. Geological Survey and the newly formed Antelope Valley Water Group (AVWG) to provide information needed to manage the water resources in the area. Funds contributed by the U.S. Geological Survey's National Water Use Information Program and the Federal/State Cooperative Program were pooled with funds contributed by the following Antelope Valley Water Group members: Los Angeles County Department of Public Works; Antelope Valley-East Kern Water Agency; city of Palmdale; city of Lancaster; Palmdale Water District; Rosamond Community Services District; and Antelope Valley United Water Purveyors.

The goals of the preliminary geohydrologic study of the Antelope Valley were to (1) estimate historical water supplies and uses and future water demands, (2) determine the magnitude and extent of land subsidence, and (3) prepare detailed study plans for evaluating the hydrogeologic environment and for developing ground-water-flow and resourceoptimization models for the Antelope Valley. This report addresses the first of these goals which was met in this land- and water-use study by (1) identifying and reviewing previous work, (2) compiling and creating data bases from local, regional, State, and Federal water agencies using data on ground-water withdrawals, deliveries, releases, or returns to surface- or ground-water sources, (3) determining the adequacy of the data bases, (4) addressing the inadequacies of these data bases by locating additional data and estimating other unaccounted for water uses, (5) establishing a plan for continuing to improve the data bases over time, and (6) providing forecasts of future local water demands for the area.

The objectives of this study of water-use in the Antelope Valley relate well to the goals for wateruse information recognized by the Congress of the United States in 1977 when they directed the U.S. Geological Survey to establish data bases to meet this need throughout the Nation. This study represents a continuation of the national cooperative water-use studies that began in 1978, which includes the comprehensive and systematic collection, storage, analysis, and dissemination of water-use information. Statistics on water use have long been valuable for effective management, planning, and development of the Nation's water resources. These statistics provide information necessary to identify and resolve critical water problems related to the environment, resource allocations, and water quality.

\section{Purpose and Scope}

This report presents estimates of historical water supply and use and estimates of future water demands that are needed for effective management of the water resources of the Antelope Valley. The study area includes the parts of Los Angeles, Kern, and San Bernardino Counties that make up the Antelope Valley. Examples of land use are described because knowledge of current and historical land use is an integral part of understanding water use in this area. Historical, current, and future land-use trends can indicate similar water-use trends because of the close relation between these two natural-resource uses. Irrigated acreage is widely used for estimating agricultural water use.

This report includes a survey of local land use and water use for the period of record (early 1900's to 1993), options for data-base maintenance, and improvements in the historical data base. Existing information on land use, water-supply sources, water-use estimates, and water-demand forecasts for the Antelope Valley was collected and evaluated. Water-supply sources identified during this study 
are ground water, local surface water (including stormwater runoff), imported surface water, and reclaimed wastewater. Both public-supplied and self-supplied water uses were identified. The sources of this information were local water suppliers, regional and statewide data bases, and estimates made from various socioeconomic and demographic variables. The reliability of the estimates of historical, current, and future water use for Antelope Valley presented in this report was evaluated by comparing all of the above related information.

\section{Previous Studies}

One of the earliest investigations of groundwater supplies in the Antelope Valley was documented by Johnson (1911) as part of a series of reports published by the U.S. Geological Survey for Southern California areas during that period. Johnson identified 353 active wells in the valley that were completed as early as 1885 , most of which were flowing wells that tapped artesian aquifers. The development of irrigation in the Antelope Vailey was described by Ewing (1945).

A study by Snyder (1955, p. viii) addressed the economic and social problems arising from the dependence on ground water in the Antelope Valley. In particular, the study focused on the "mining" of ground water in the semiarid, hydrologically self-contained valley. The study called attention to the highly variable but small volume of recharge to the aquifer system and addressed economic and social forces that could affect balancing recharge and discharge before the ground-water storage was depleted. Snyder determined that there was "no simple solution" to the ground-watermanagement problem but suggested that the following actions could be taken: (1) education to change crop patterns and water application, (2) local zoning ordinances to limit and reduce ground-water pumpage, (3) legislation of State ground-water laws, and (4) importation of surface water.

A report by the Califomia Department of Public Works (1955) described water conditions in the Antelope Valley on the basis of data available at that time. This report documented that the highest estimated ground-water pumpage during 1 year in the Antelope Valley was about 480,000 acre-ft and occurred in 1953. Total irrigated acreage was estimated to be 73,600 acres with alfalfa accounting for 62,100 acres.
The first phase of a study on water management by the California Department of Water Resources, local agencies, and the U.S. Geological Survey produced the first ground-water-flow model for the Antelope Valley (Durbin, 1978, p. 49). The second phase of that study used the model to evaluate the possible results of various water-management alternatives. This phase was documented in a report by the California Department of Water Resources (1980). The report included the results of a survey of water supply and demand for the Antelope Valley, which was used to develop plans for coordinated use of the various available water supplies (ground water, imported water, local surface water, and reclaimed wastewater) for 1975 to 2020 . Present and historical population projections for the Antelope Valley for the year 2000 have ranged from a low of 106,000 to a high of 476,000 . The population was projected to grow from 94,000 in 1975 to 320,000 by 2020 (California Department of Water Resources, 1980). Irrigated acreage also could not be projected reliably and, therefore, was held constant at the 1975 level (35,000 acres). Since 1980, additional water-supply and demand estimates for the Antelope Valley have been provided by the California Department of Water Resources $(1987,1988,1990 \mathrm{a}, 1990 \mathrm{~b}, 1991 \mathrm{~b}$, and 1993a).

Law Environmental (1991) presented a report on available data for the Los Angeles County part of the Antelope Valley and concluded, as did Snyder (1955), that a combination of best-management practices could improve ground-water conditions in the area.

\section{Acknowledgments}

The authors wish to acknowledge the assistance of many water district personnel in the Antelope Valley, but especially the active leaders of the water community who make up the Antelope Valley Water Group, for their foresight, cooperation, and input throughout this project. We also would like to recognize the assistance of Vern T. Knoop, David Inouye, and Glenn I. Bergquist, California Department of Water Resources; Javier Minjares, Southern California Association of Governments; and Gregory Poseley, California Department of Conservation, for supplying their land-use and water-use information for the study area and for their cooperation on comparing land-use maps from various sources with their maps and the supporting aerial photography. We also appreciate the advice 
and assistance of Eva Opitz, Planning Management Consultants, Ltd., and Shane Chapman, Metropolitan Water District of Southern California, in this initial application of the MWD_MAIN system for forecasting urban water demands in the Antelope Valley.

\section{DESCRIPTION OF STUDY AREA}

Antelope Valley is in the southwestern part of the Mojave Desert in southern California (fig. 1). Most of the valley is in Los Angeles County and Kern County, and a small part of the eastern valley is in San Bernardino County. The valley is triangular in shape and lies between the San Andreas Fault on the southwest and the Garlock Fault on the northwest. The study area is about $2,400 \mathrm{mi}^{2}$. The land-surface elevation in the study area ranges from about 2,300 to $3,500 \mathrm{ft}$ above sea level. Native vegetation includes Joshua trees, saltbrush, mesquite, sagebrush, creosote bush, and other highdesert plants.

The valley is semiarid, receiving an average of less than $10 \mathrm{in}$. of precipitation annually on the valley floor and more than 12 in. of precipitation in the surrounding mountains (Rantz, 1969). Precipitation totals for 1928-91 for the Leona Valley, Palmdale, and Lancaster (fig. 2) indicate the annual variability and regional differences in the Antelope Valley. Annual and regional variations in precipitation are important to the annual variations in applied water required for crop production and

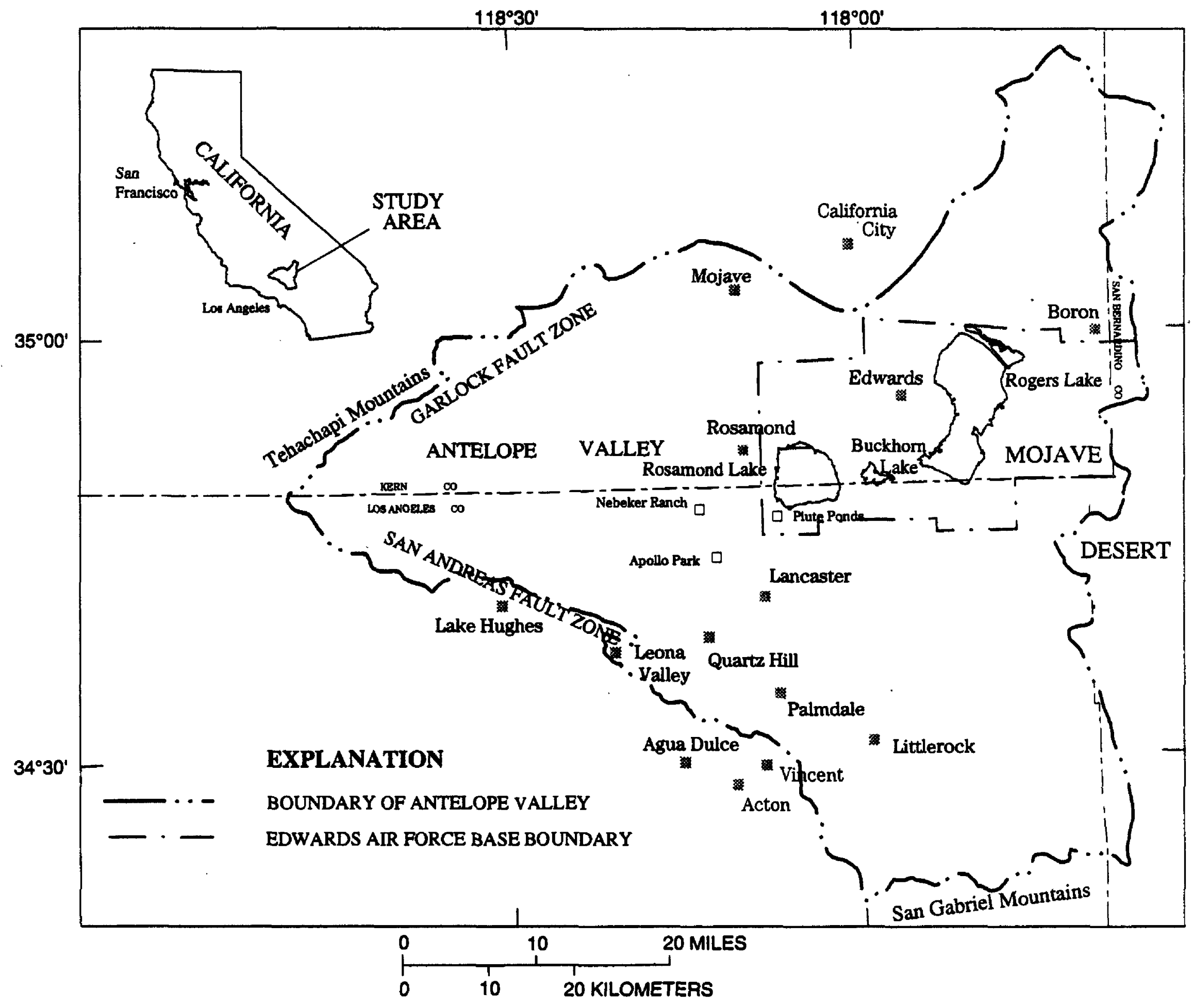

Figure 1. Location of the Antelope Valley, California. 


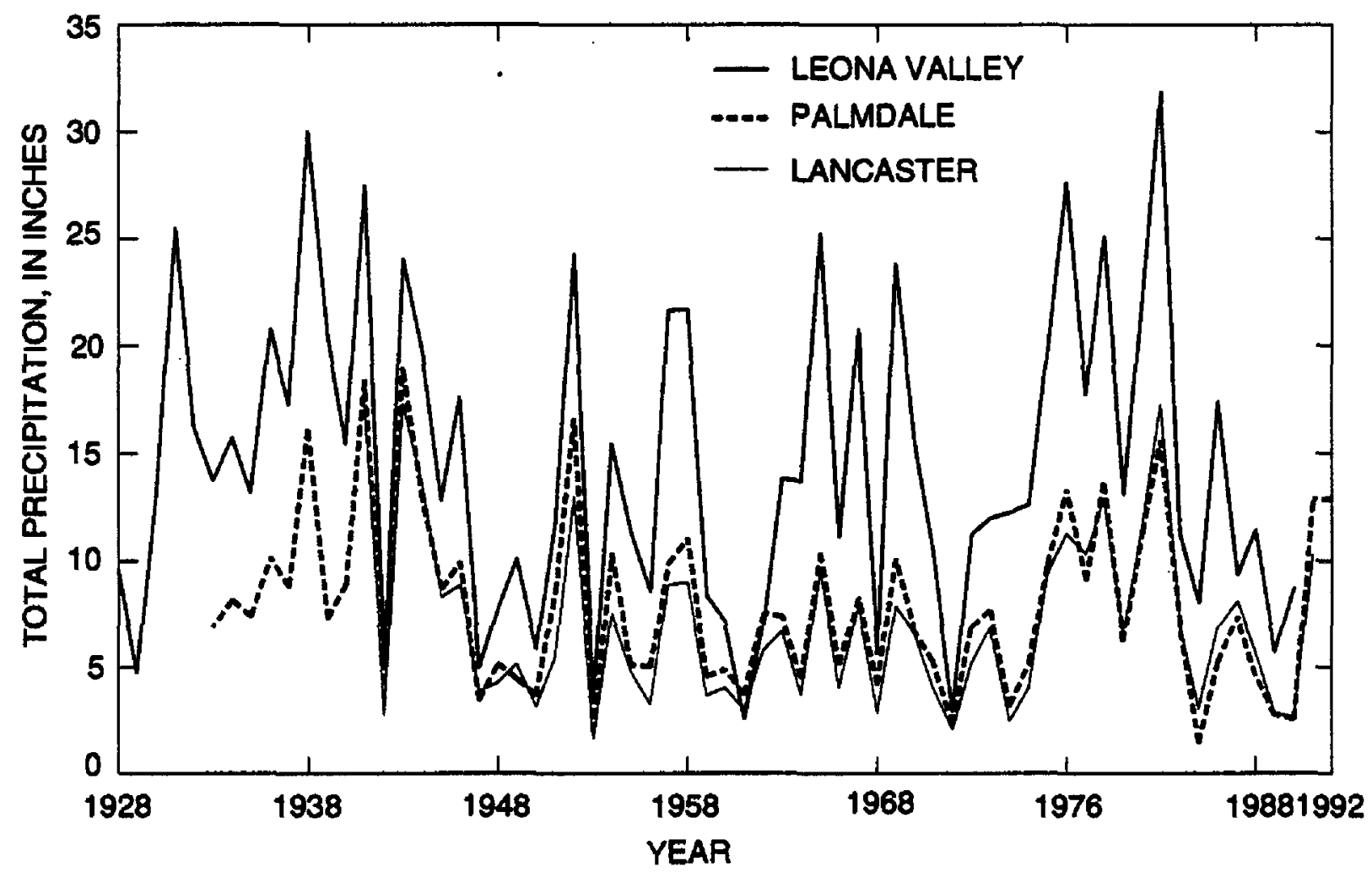

Figure 2. Annual precipitation for the Leona Valley, Palmdale, and Lancaster in the Antelope Valley (Joel Guay, U.S. Geological Survey, written commun., 1993.)

urban landscape maintenance. Rainfall records indicate that runoff sometimes may be available that could be retained and used for artificial groundwater recharge. Eighty percent of the mean annual precipitation, including some snow, falls in winter. The mean summer temperature is $78^{\circ} \mathrm{F}$ and mean daily summer temperatures range from 63 to $93^{\circ} \mathrm{F}$. The mean winter temperature is $45^{\circ} \mathrm{F}$ and mean daily winter temperatures range from 34 to $57^{\circ} \mathrm{F}$. The growing season is primarily from April through October (Duell, 1987).

Actual populations in 1980 and 1990 and the forecasted population for 2010 for the valley are $124,350,260,400$, and 690,000 , respectively (Dolores Lykins, California Department of Finance, written commun., 1993). Actual populations in 1980 and 1990 and projected populations for 2010 for the following communities are

$\begin{array}{lrrr}\text { Lancaster } & \underline{1980} & \underline{1990} & \underline{\underline{2010}} \\ \text { Palmdale } & 12,277 & 54,291 & 212,140 \\ \text { Edwards Air } & & & 226,425 \\ \quad \text { Force Base } & 8,554 & 7,423 & 7,671 \\ \text { Rosamond } & 2,869 & 5,467 & 23,372 \\ \text { Mojave } & 2,886 & 1,944 & 8,737 \\ \text { Boron } & \underline{2,815} & \underline{2,903} & \underline{3,071} \\ & 7 \overline{7,428} & 169,748 & 48 \underline{1,416} \\ & 62 \% \text { of } & 65 \% \text { of } & 70 \% \text { of } \\ & 124,350 & 260,400 & 690,000\end{array}$

These six communities represent 62,65 , and 70 percent of the population of the Antelope Valley in 1980, 1990, and 2010, respectively. Actual and forecasted population trends and distributions between 1960 and 2010 suggest potential for increasing localized stress on the water resources from urban growth in the valley. The range in population projections (fig. 3 ) indicates inaccuracies that are inherent in the process of attempting to forecast future socioeconomic conditions. Population forecasts are as variable now as they were in 1976. The population forecasts for a study by the California Department of Water Resources (1980) were considered the best available at that time. Projections made in 1976 for 1990 were about 30 percent lower than actual populations. The projected population for the Antelope Valley for the year 2000 by the California Department of Finance (1993) is 25 percent higher than the population projected by Alfred Gobar and Associates (1993). Many variables presently (1994) cannot be predicted with accuracy, including national and local economics and construction of major transportation facilities (for example, a proposed international airport at Palmdale and a proposed high-speed rail line through Palmdale). Various population forecasts are presented in this report to show the range in estimates of population growth that presently (1994) exists.

California City, Acton, Agua Dulce, Vincent, and Lake Hughes are outside the boundary defined as the Antelope Valley but are within the Antelope Valley-East Kern Water Agency service area. Demand for water outside the Antelope Valley may decrease the availability of imported water for the Antelope Valley water users. Growth plans for these communities are an important consideration in terms of future availability of imported water. For example, actual populations in 1980 and 1990 and forecasted population for 2010 for California City are 7,$384 ; 15,075$; and 36,185 , respectively, indicating a significant increase in future water demand. 


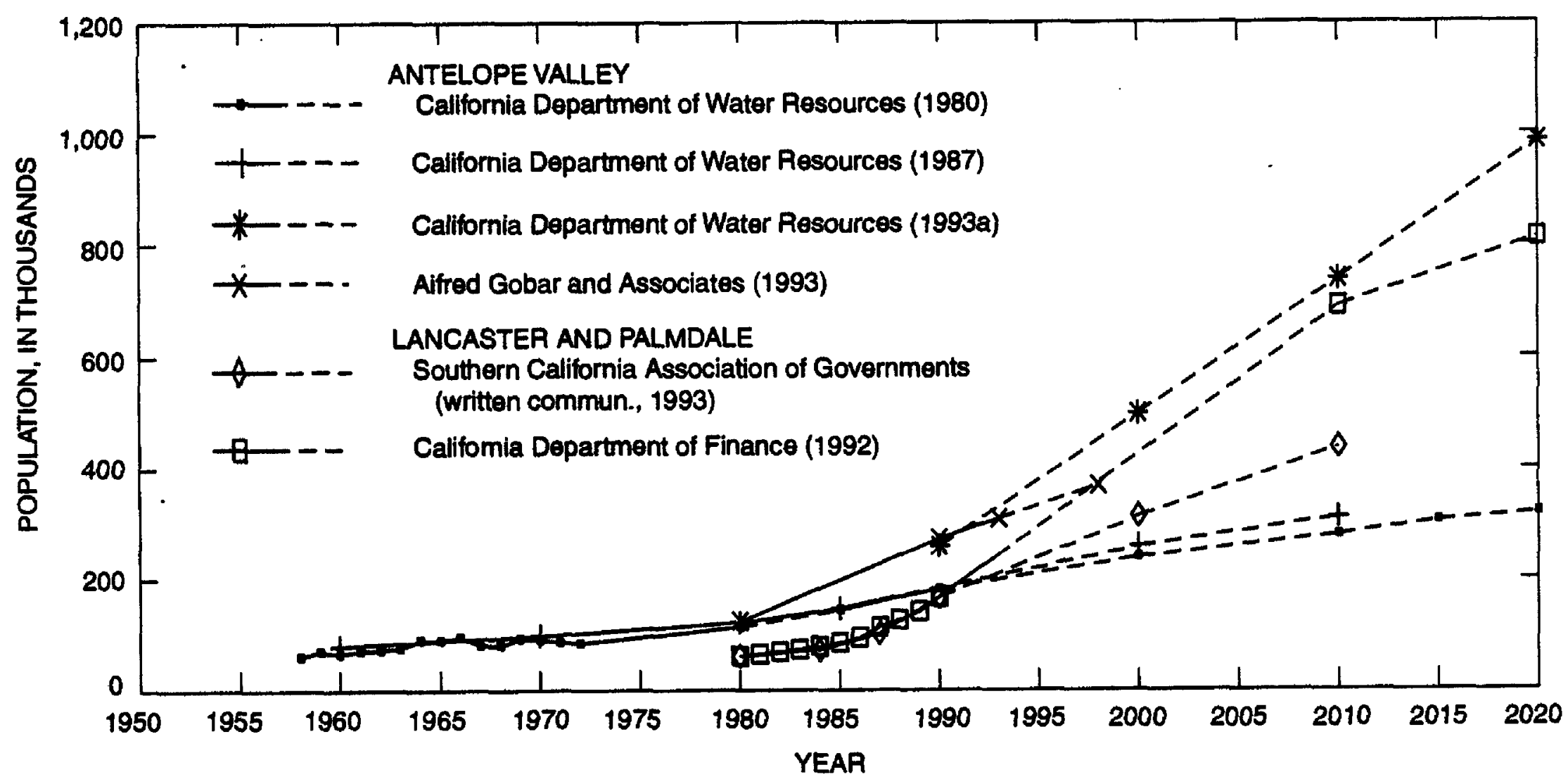

Figure 3. Population trends and projections (dashed part of lines) for the Antelope Valley, 1960-2020.

\section{LAND USE}

Water use in the Antelope Valley varies directly with land use. Historically, this valley was developed primarily around alfalfa farming and the aerospace industry. Water use required for production of crops is related directly to the acreage of land irrigated, crop-water requirements, irrigation methods practiced, and other factors such as effective precipitation, soil-salt leaching requirements, and soil conditions. As agricultural land use has decreased, agricultural water use similarly has decreased, and as urban land use has increased, urban water use also has increased. The net change has been a decrease in water use since the 1950's.

The change in land use from agricultural to urban is reflected in the land-use information for 1973-92 (figs. 4-7). Large cropland and pasture areas shown in the land-use map for the mid-1970's (fig. 4) represent about 35,000 acres, less than half of the 73,000 acres irrigated in the early 1950's (fig. 6, table 1). Similar reductions in water use have been observed (California Department of Public Works, 1955; California Department of Water Resources, 1980 ). By 1987, irrigated land had decreased from 73,000 to 15,762 (22 percent) acres and by 1992 it had decreased to 12,854 (18 percent) acres (fig. 5). Land-use maps for 1984 and 1990 (fig. 7) confirm these trends, showing a decrease in prime farmland (12 percent) and an increase in residential and other urban acreage (46 percent). Land-use planning for urban expansion is emphasized in additional mapping of future planned conditions done in 1990 by the Los Angeles County Department of Regional Planning (not available for inclusion in this report). This mapping indicates that increased urban land use is expected and that similar increases in water use can be anticipated.

Land-use mapping can be done at various levels of detail as described by Anderson and others (1976, p. 7). They defined four levels of land-use mapping on the basis of the source and resolution of remotely sensed data. Resolution is the detail that can be shown on a map and is dependent on altitude and scale. The following description of a multilevel land-use and land-cover classification system helps in understanding these variations. Level I and Level III land-use data for the Antelope Valley are presented in this report.

Classification level Typical data characteristics

$\begin{array}{cl}\text { I } & \text { Satellite-imagery data } \\ \text { II } & \text { High-altitude data taken at } \\ \text { altitudes greater than } 40,000 \\ \text { ft above land surface (less } \\ \text { than } 1: 80,000 \text { scale) } \\ \text { III } \\ \text { Medium-altitude data taken at } \\ \text { altitude between } 10,000 \text { and } \\ 40,000 \mathrm{ft} \text { above land surface } \\ \\ \text { (1:20,000 to } 1: 80,000 \mathrm{scale}) \\ \text { IV } \quad \text { aw-altitude data taken at } \\ \text { altitude below } 10,000 \mathrm{ft} \\ \text { above land surface (more } \\ \text { than } 1: 20,000 \text { scale). }\end{array}$


Table 1. Irrigated and nonirrigated land use by year and crop type

[See footnotes for sources used. Acreage by crop type may not always provide total irrigated acreage when some data were not available. --, no data available]

\begin{tabular}{|c|c|c|c|c|c|c|c|c|}
\hline \multirow[b]{2}{*}{ Year } & \multicolumn{6}{|c|}{ Irrigated land use by crop type, in acres } & \multicolumn{2}{|c|}{ Total, in acres } \\
\hline & Alfalfa & $\begin{array}{l}\text { Pasture } \\
\text { and turf }\end{array}$ & Grain & $\begin{array}{l}\text { Field } \\
\text { crops }\end{array}$ & Truck & $\begin{array}{l}\text { Deciduous } \\
\text { trees/vines }\end{array}$ & Irrigated & $\begin{array}{c}\text { Non- } \\
\text { irrigated }\end{array}$ \\
\hline \multicolumn{9}{|c|}{ Los Angeles County part of Antelope Valley } \\
\hline 1940 & 26,600 & -- & 100 & -- & 400 & 2,183 & 29,283 & 49,552 \\
\hline 1941 & 26,600 & -- & 100 & -- & 400 & 2,222 & 29,322 & 51,292 \\
\hline 1942 & 26,600 & -- & 100 & -- & 400 & 2,239 & 29,339 & 47,109 \\
\hline 1943 & 25,600 & -- & 100 & -- & 400 & 2,150 & 28,250 & 46,075 \\
\hline 1944 & 26,600 & -. & 100 & -- & 380 & 2,035 & 29,115 & 45,795 \\
\hline 1945 & 30,200 & -- & 100 & -- & 475 & 1,870 & 32,645 & 48,025 \\
\hline 1946 & 33,100 & -- & 100 & -- & 1,035 & 1,902 & 36,137 & 48,425 \\
\hline 1947 & 36,730 & 252 & 100 & -- & 953 & 2,032 & 40,067 & 53,860 \\
\hline 1948 & 37,320 & 456 & 100 & 420 & 1,287 & 2,057 & 41,640 & 54,820 \\
\hline 1949 & 39,035 & 85 & 100 & 760 & 625 & 2,242 & 42,847 & 57,740 \\
\hline 1950 & 34,125 & 91 & 100 & 2,720 & 716 & 2,260 & 40,012 & 55,092 \\
\hline 1951 & 34,945 & 1,341 & 100 & 3,890 & 915 & 2,342 & 43,533 & 9,332 \\
\hline 1952 & 36,550 & 1,380 & 100 & 4,100 & 585 & 2,224 & 44,939 & 54,074 \\
\hline 1953 & 37,900 & 2,330 & 100 & 4,300 & 770 & 2,299 & 47,699 & 50,582 \\
\hline \multicolumn{9}{|c|}{ Antelope Valley, total } \\
\hline$\overline{1910^{2}}$ & 2,500 & - & -- & $\overline{--}$ & -- & 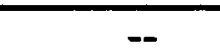 & -- & $\overline{--}$ \\
\hline $1912^{2}$ & -- & -- & -- & -- & -- & -- & 4,629 & -- \\
\hline $1916^{2}$ & -- & -- & -- & -- & -- & -- & 10,000 & -- \\
\hline $1919^{2}$ & 7,155 & -- & -- & -- & -- & 4,655 & 11,810 & -- \\
\hline $1920^{2}$ & 7,400 & -- & - & -- & -- & 4,900 & 12,300 & -- \\
\hline $1922^{2}$ & 7,000 & -- & - & -- & -- & 4,700 & -- & -- \\
\hline $1924^{2}$ & 12,000 & -- & -- & -- & -- & 4,780 & 16,780 & -- \\
\hline $1929^{2}$ & 25,000 & $\cdots$ & -- & -- & -- & -- & -. & -- \\
\hline $1930^{2}$ & 22,000 & -- & -- & -- & -- & -- & -- & -- \\
\hline $1931^{2}$ & 21,700 & -- & -- & -- & -- & -. & -- & -- \\
\hline $1934^{2}$ & 15,317 & -- & -- & -- & -- & -- & 23,800 & -- \\
\hline $1935^{2}$ & 16,000 & -- & -- & -- & -- & -- & -- & -- \\
\hline $1938^{2}$ & 23,000 & -- & -- & -- & -- & -- & -- & -- \\
\hline $1940^{2}$ & 24,202 & 1,113 & -- & -- & -- & 1,950 & -- & -- \\
\hline $1945^{2}$ & 29,600 & 5,850 & -- & -- & -- & 1,870 & 37,320 & -- \\
\hline $1949^{3}$ & 62,100 & 100 & 4,200 & 200 & 100. & 4,500 & 71,200 & 88,470 \\
\hline $1950^{2}$ & 38,525 & 13,022 & - & - & - & 2,375 & 53,922 & -- \\
\hline $1959^{3}$ & - & -- & -- & - & - & -. & 50,000 & -- \\
\hline $1975^{3}$ & -- & -- & -- & -- & -- & -- & 35,000 & -- \\
\hline $1987^{4}$ & 8,810 & 1,050 & 1,330 & 60 & 2,380 & 2,000 & 15,630 & -- \\
\hline $1987^{5}$ & 8,624 & 1,246 & 1,290 & 15 & 2,511 & 2,076 & 15,762 & -- \\
\hline $1988^{6}$ & 9,000 & 700 & 400 & 200 & 3,000 & 2,000 & 15,300 & -- \\
\hline $1992^{7}$ & 6,124 & 955 & 835 & 32 & 2,645 & 2,263 & 12,854 & -- \\
\hline \multicolumn{9}{|c|}{ Antelope Valley, projected } \\
\hline 2000 & 500 & 100 & $\overline{0}$ & 50 & 200 & 1,350 & 82,200 & -- \\
\hline 2010 & 0 & 0 & 0 & 20 & 0 & 1,200 & ${ }^{8} 1,220$ & -- \\
\hline 2020 & 0 & 0 & 0 & 0 & 0 & 900 & ${ }^{8} 900$ & -. \\
\hline
\end{tabular}

${ }^{1} 1940-53$ (California Department of Public Works, 1955, p. 18).

${ }^{2}$ Snyder (1955, p. 161-162).

${ }^{3} 1949$ (California Department of Public Works, 1955, p. 16); 1959 and 1975 (California Department of Water

Resources, 1980, p. 12).

${ }^{4}$ California Department of Water Resources (1990b, p. 39).

${ }^{5}$ U.S. Geological Survey data bases, May 1994. Original quadrangle data used in California Department of Water Resources (1990b) were digitized for this study.

${ }^{6}$ California Department of Water Resources (1990a).

${ }^{7}$ U.S. Geological Survey data bases, May 1994.

${ }^{8}$ Preliminary projected total irrigated acreages in California Department of Water Resources (1993a, v. 2, p. 261) were rounded off to 2,000 acres in the year 2000;1,000 acres in the year 2010; and 1,000 acres in the year 2020 . 


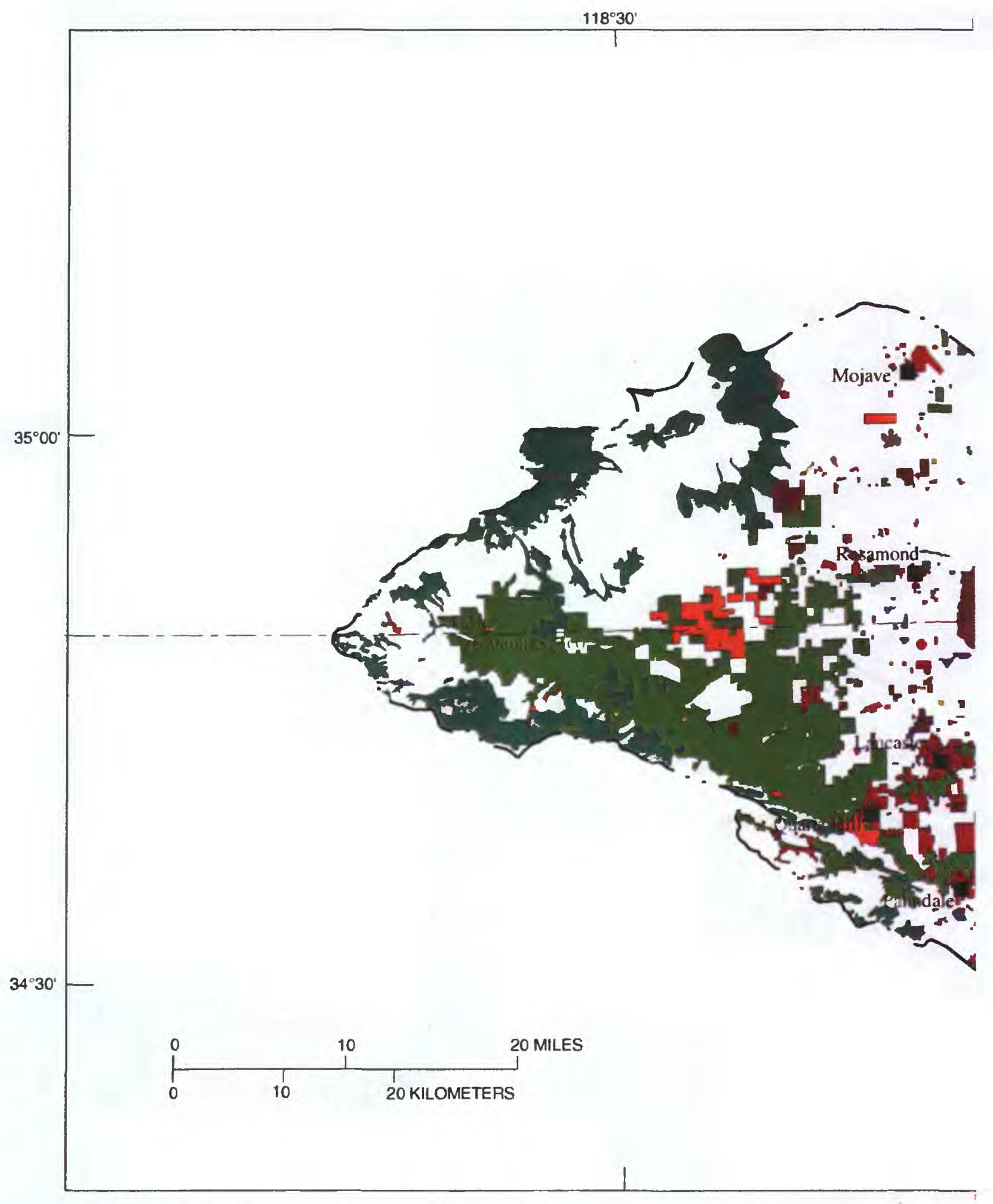

Figure 4. Land use in the Antelope Valley, 1973-77. 


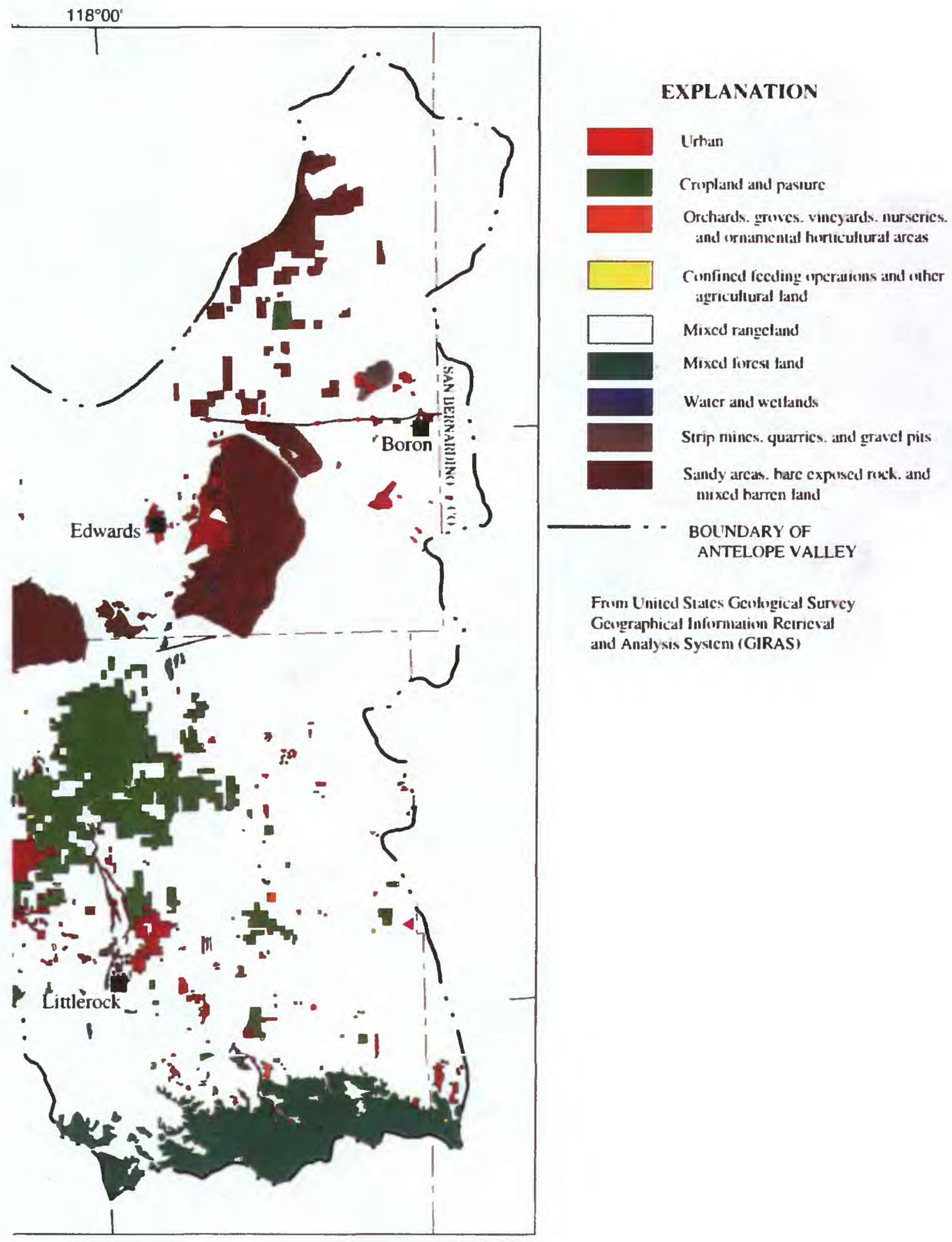




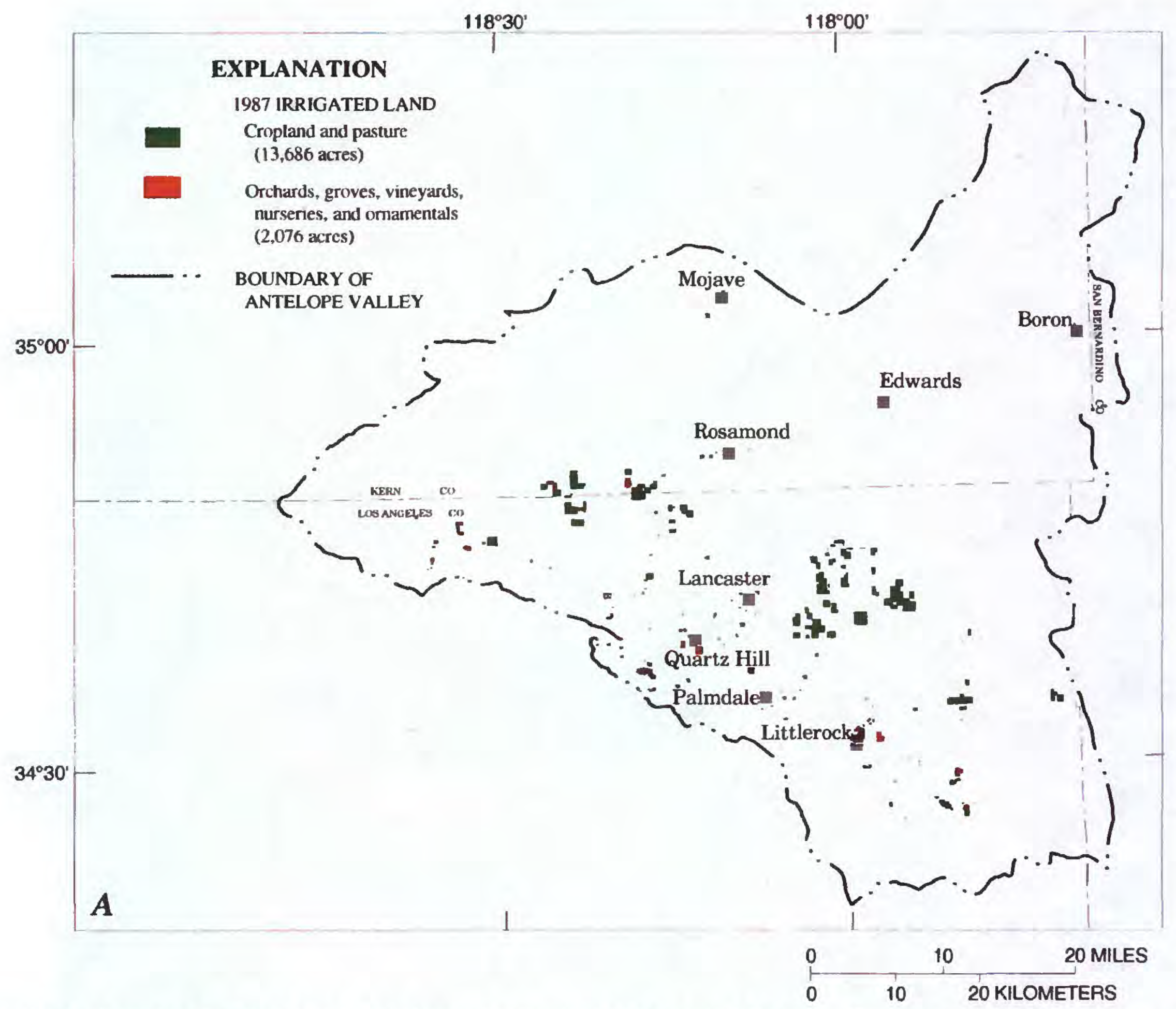

Figure 5. Land use by crop type in the Antelope Valley for A 1987 and B 1992. (Sources: California Department of Water Resources and U.S. Geological Survey data bases.)

\section{Land-Use Classification for National Resource Appraisal, U.S. Geological Survey}

Land-use mapping by the U.S. Geological Survey using the Geographic Information Retrieval and Analysis System (GIRAS) for national resource appraisal (fig. 4) is an example of Level I of the land-use classification system. Anderson and others (1976) describe this large-scale, nationwide mapping $(1: 100,000$ or $1: 250,000$ scale) and the various uses of these maps. For water-use purposes, this level of mapping can indicate the types of water use in any area mapped in the nation; comparison with subsequent maps can show land-use changes - and resulting water-use changes-over time. This mapping also shows an example of what can be done with satellite imagery. Because of the relatively low resolution of the high-altitude imagery, emphasis is given to generalized land-use classifications. Irrigated land use in the Antelope Valley in 1975 (35,000 acres) was less than one-half of irrigated land use reported for the valley in 1949 (71,200 acres) (table 1). Urban land use in 1973-77 (fig. 4) is small compared with urban use in 1984 and 1990 (fig. 7).

\section{Land-Use Classification for Statewide Planning, California Department of Water Resources}

Level III of the land-use classification system is used statewide by the California Department of Water Resources to estimate water use for planning for future growth and for water management. One example of Level III land-use mapping for the Antelope Valley is the statewide mapping of urban 


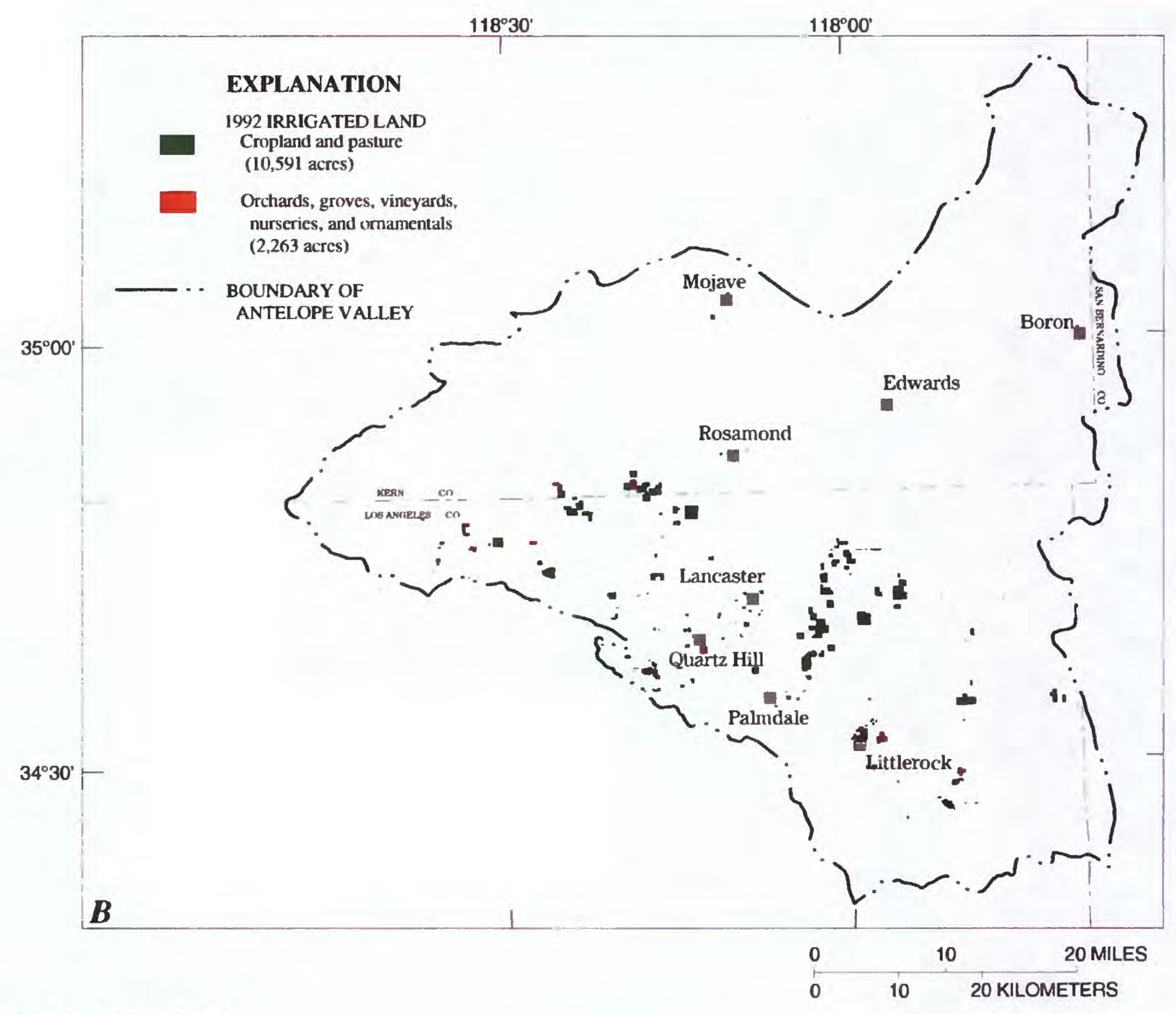

Figure 5.--Continued

lands, native vegetation, and irrigated and nonirrigated agricultural land done periodically by the California Department of Water Resources, Land and Water Use Sections (fig. 5). This mapping is done using aerial photography on 1:24,000 scale and 7.5-minute U.S. Geological Survey topographic quadrangle base maps and then is field verified with site visits. Emphasis is given to agricultural land use, which is required to estimate water use on the basis of acreages of irrigated crops and crop-water demands. Although the acreages and types of crops grown in the valley during the period of record have changed with time, alfalfa continues to be the primary crop (table 1). Crop diversity and total irrigated acreage has decreased greatly since the 1950 's.

This method of land-use mapping has been used by the California Department of Water Resources to estimate water use in the Antelope Valley for more than 40 years. In 1949, 71,200 acres were reported to have been irrigated in the Antelope Valley. Irrigated acreage decreased to $35,000,15,762$, and 12,854 acres by 1975,1987 , and 1992 , respectively (table 1). Land-use surveys in Antelope Valley were done in 1958, 1961, 1972, and 1987 (California Department of Water Resources, 1958; $1965 ; 1974 ; 1990$ b, p. 39). Some small differences in total acreages of crop types were noted during this study (table 1) when land-use maps done for 1987 by the California Department of Water Resources (1990b) were digitized for this study. These differences may be due to the accuracy limitations of the "cut and weigh" methods that historically have been used to estimate irrigated acreage or may be due to interpretations of land-use boundaries during digitizing. A survey of land use in the area done in 1992 as part of this study 


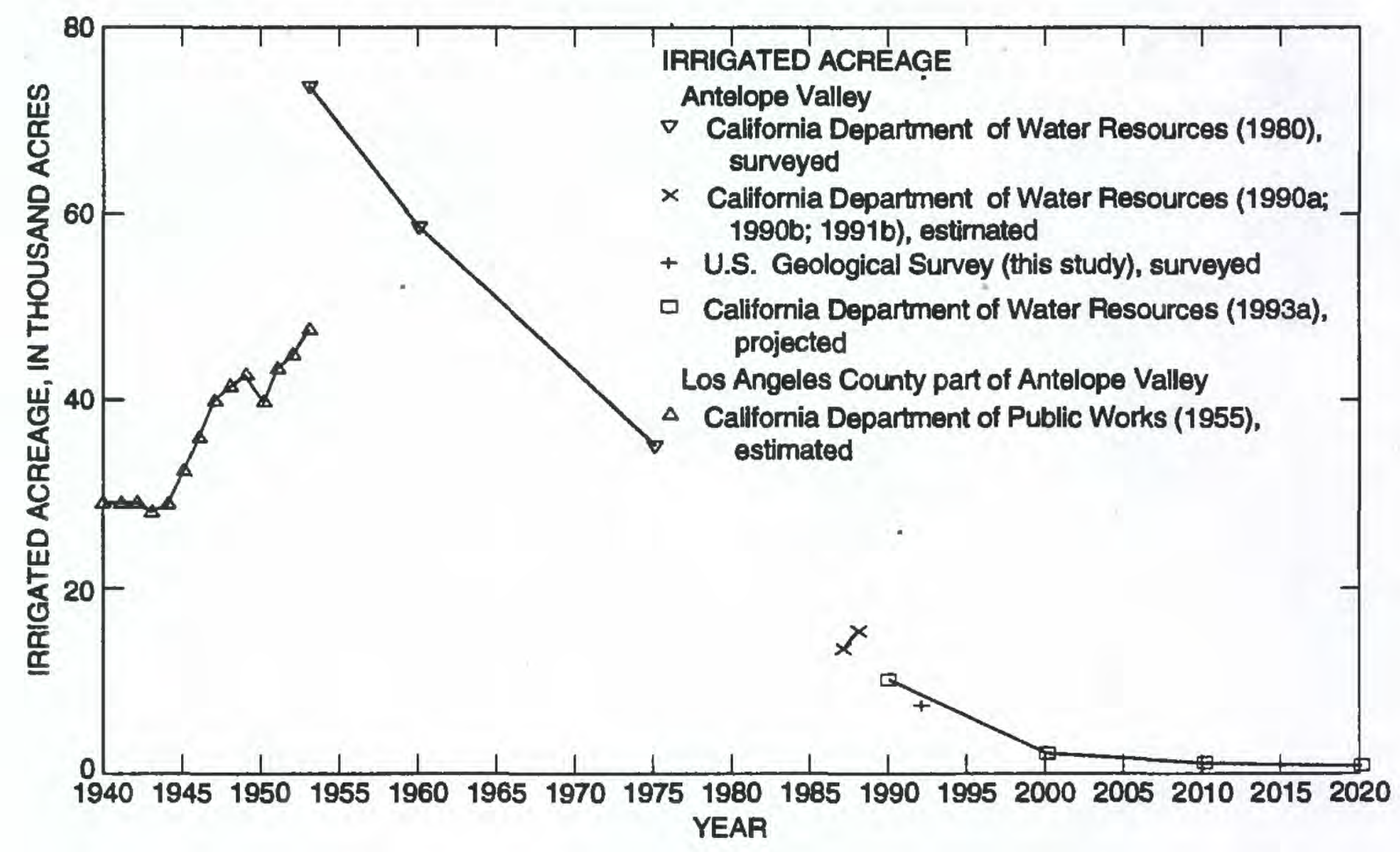

Figure 6. Surveyed, estimated, and projected land use for irrigated acreage for selected years, Antelope Valley.

indicates that cropland (primarily alfalfa) and pasture accounted for 10,591 acres of irrigated acreage (a decrease from 13,686 acres in 1987) and orchards and vineyards accounted for the remainder of the irrigated acreage, 2,263 acres (an increase from 2,076 acres in 1987). In 1987, irrigated turf areas, such as golf courses and playgrounds, accounted for 775 acres in the Antelope Valley. By 1992, irrigated turf areas increased to 895 acres and included a commercial turf farm.

Projections by the California Department of Water Resources (1993a, p. 261) for irrigated acreage in the Antelope Valley indicate a decrease in total irrigated acreage to about 2,000 acres by the year 2000; 1,000 acres by 2010; and remaining at about 1,000 acres by 2020 (table 1). These projections for irrigated acreages may be low even if we assume that no surface water or ground water will be used for irrigation by 2020 . In 1990, 3,587 acre-ft of reclaimed wastewater was used for irrigation in the Antelope Valley. At 6 acre-ft/acre, almost 600 acres of alfalfa could have been irrigated. Assuming that the population increases as projected and that the present limited conservation actions continue, two or three times as much wastewater could be available for irrigation. By 2020 , 1,200 to 1,800 acres could be irrigated using only reclaimed wastewater. In addition, increased use of efficient irrigation methods, such as drip irrigation, could result in increased acreage of crops that can be drip irrigated.

\section{Land-Use Classification for Documenting Changes of Prime Farmland to Urban Use, California Department of Conservation, Farmland Mapping Program}

The California Department of Conservation, Farmland Mapping Program uses Level III of the land-use classification system to document changes of prime farmland to urban use. A significant change in agricultural and urban land use occurred in the Antelope Valley between 1984 and 1990 (fig. 7). Land use for 1984 was mapped only for the Los Angeles and San Bernardino County parts of the Antelope Valley. The Kern County part of Antelope Valley was mapped for 1990 . These maps show the changes in prime farmland and residential urban use. In the Los Angeles County part of the study area, urban land has expanded about 46 percent (from 26,259 to 38,422 acres) and agricultural land has decreased about 13 percent (from 55,389 to 48,933 acres) between 1984 and 1990 in the Antelope Valley, as determined from digitized maps for this study. Water use, which is related to land use, changes with changes in 


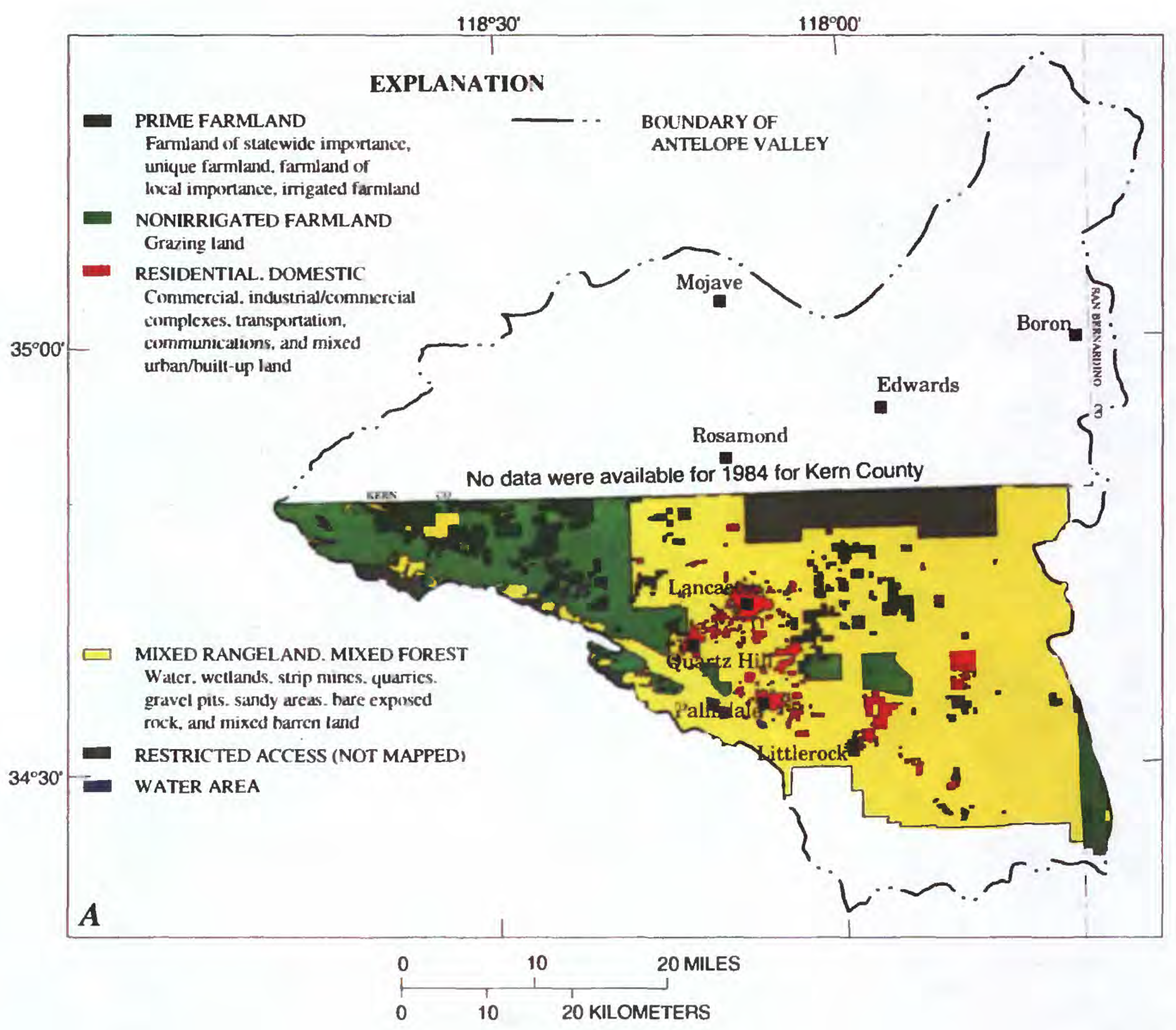

Figure 7. Land use in the Antelope Valley for A 1984 and B 1990. (Sources: California Department of Conservation, Farmland Mapping Program.)

irrigated acreage and urban land use. Therefore, changes in land use can be used to verify changes in water use for the same periods of time.

\section{Land-Use Classification for Regional Planning, Los Angeles County Department of Regional Planning}

A final example of Level III land-use mapping was done by the Los Angeles County Department of Regional Planning in cooperation with a consor- tium of southern California agencies for part of the Antelope Valley. In 1990, they mapped the Los Angeles County part of the study area and presently are working on an update for 1993. Aerial Information Systems (1992) modified the land-use classification system by Anderson and others (1976) to identify subgroups in greater detail. For example, the classification system by Anderson and others (1976) was further divided into classifications of single-family residential and multifamily residential with population densities also specified. These maps can be used to interpret the effects of 


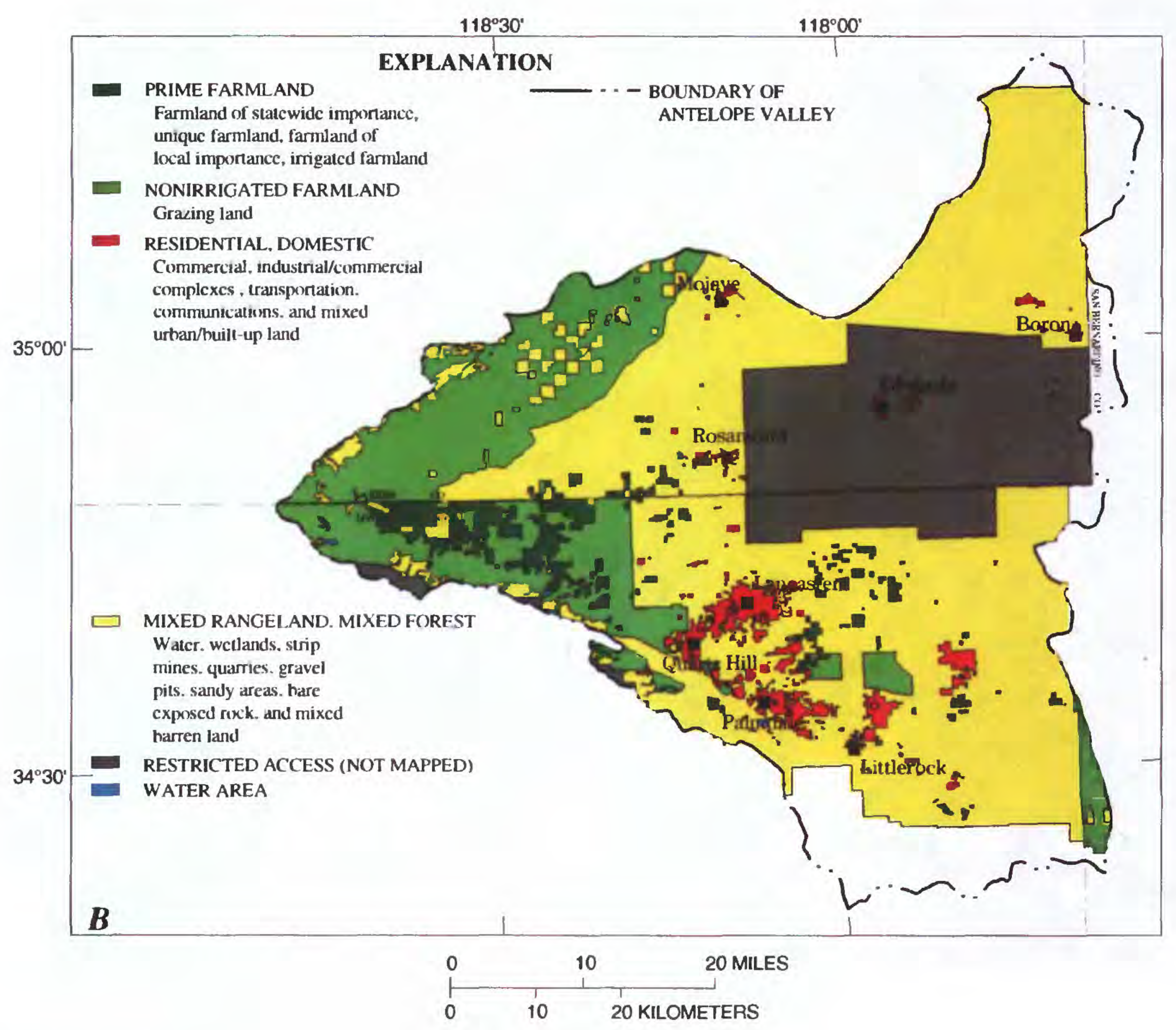

Figure 7. Continued.

concentrated urban growth in areas of natural ground-water recharge. For example, these maps could help future studies because the conversion of native vegetation areas to urban areas can have dramatic negative effects on recharge rates, groundwater quality, and localized stress on the aquifer. This classification system was modified by Los Angeles County Department of Regional Planning to emphasize urban land use. These maps were not available for inclusion in this report but are now available at the office of the Los Angeles County Department of Regional Planning. These maps may be available for use in digital form in the future to help anticipate and reduce effects on local groundwater levels and related land subsidence.

\section{WATER USE}

An evaluation of water use requires information related to water supply and demand. In U.S. Geological Survey reports, the meaning of the term "water use" has expanded over the years from initially meaning only supply, represented as withdrawals of water, to now include supply and demand, represented by (1) withdrawals from sources of water supplies, (2) deliveries to meet water demands by various categories of water use, (3) releases from points of use, and (4) returns to surface- and ground-water supply sources. For the purposes of this study, water supply is the water available from each water-supply source, such as 
ground water, surface water, imported water, and reclaimed wastewater, that is used to meet demands. Water demand is the volume of water required to meet the needs of irrigation, industrial, domestic, commercial and other water users. Ground-water pumpage is the quantity of water withdrawn from ground-water-supply sources to meet water demands. Data are not always available for all types of water use; thus programs need to be developed to collect these data. Presently (1994) in California, water conservation, or "demand management," also is considered a water-supply source. Water demand in the Antelope Valley historically has been discussed in two general categories, agricultural and municipal, which generally equate to self-supplied and publicsupplied demands in this report.

Water demand can be estimated from land use. Changes in land use can help provide an understanding of shifts in water sources and relative locations of stress on regional ground-water resources. Such changes can provide an indication of where we can expect resultant changes in ground-water pumpage and water levels. Understanding the relation between shifting land uses and stress on local aquifers can be used to help optimize the management of ground water by distributing pumping to minimize declines in ground-water levels in any specific area.

\section{Water Supply}

In an attempt to validate previously published water-supply and demand information, a data base was created for this study using data reported by water suppliers. Historical water-supply information for the Antelope Valley was obtained by reviewing available published literature. Previous work indicates that since development of the Antelope Valley in the late 1800's ground water has been the primary water-supply source. Total water supplies for the Antelope Valley estimated by the Califormia Department of Water Resources (1980, p. 17; 1990a; and 1991b) were about 192,600 acre-ft in 1975, 168,000 acre-ft in $1980,152,000$ acre-ft in 1985, and 118,000 acre-ft in 1988 and 1989 (table 2). Recent projections (table 2) by the Califormia Department of Water Resources indicate that imported surface water is expected to become the primary water source for Antelope Valley by 2010.
Values in table 2 come from several different reports and were estimated in different ways. For example, estimates of "total water supply" by the California Department of Water Resources for 1975 and by the U.S. Geological Survey for 1989, 1990, and 1991 equal "total applied" demands, thus accounting for supply sources for all water demands. However, the California Department of Water Resources estimates of "total water supply" equal the "net water demands" for 1980, 1985, 1988 , and 1989. The additional water supply that is required to meet "total applied demands" may be recycled water or it may be returning to the primary producing aquifers as ground-water recharge. For example, in 1988, that recharge would have been 19,000 acre-ft $(137,000$ acre- $f t$ minus 118,000 acre$\mathrm{ft})$. Therefore, in 1988, total ground-water withdrawals may have been 88,000 acre-ft $(69,000$ acre-ft plus 19,000 acre-ft) and in 1989 total ground-water withdrawals would have been 79,000 acre-ft $(53,000$ acre-ft plus 26,000 acre-ft). Further descriptions of "net" water demand and "total applied" water are in the discussion of ground-water supply later in this report.

The following is an overview of water-supply data reported by water suppliers in the Antelope Valley compiled for this study (fig. 8). This study relied on available data reported by or to various public agencies. Many inherent inaccuracies in reported water use have been identified by previous studies in other states (Kenny, 1986; Holland and Baker, 1993). This study, however, serves as a first step toward improving the reliability of water-use information for the Antelope Valley by documenting the limitations of the existing data. Specific information on the sources of the data and related discussions on each data base follow this overview of water supply. Estimates of total water supply (mostly from ground water) for the Antelope Valley in 1953 were as high as 480,000 acre-ft (California Department of Public Works, 1955). Water supplies available for use in the Antelope Valley (Los Angeles County part only) reportedly peaked in 1956 at about 270,000 acre-ft and then decreased until 1972, with total reported water supplies used that year about 100,000 acre-ft (fig. 8). Annual total reported water-supply use increased to nearly 150,000 acre-ft in 1978, with increased imported water into the Antelope Valley. Between 1981-83, annual total reported use of available water supplies decreased dramatically, reaching a low of about 90,000 acre-ft/yr. An 
Table 2. Water supplies and demands in the Antelope Valley, with historical and recent projections to 2020

[Imported water represents water purchased from California State Water Project contractors by water suppliers within this study-area boundary for the Antelope Valley. -., no data available]

\begin{tabular}{|c|c|c|c|c|c|c|c|c|c|c|}
\hline \multirow[b]{2}{*}{ Year } & \multicolumn{5}{|c|}{ Water-supply source, in acre-feet per year } & \multicolumn{5}{|c|}{ Water demands, in acre-feet per year } \\
\hline & $\begin{array}{l}\text { Ground } \\
\text { water }\end{array}$ & $\begin{array}{l}\text { Local } \\
\text { surface } \\
\text { water }\end{array}$ & $\begin{array}{l}\text { Imported } \\
\text { water }\end{array}$ & $\begin{array}{l}\text { Reclaimed } \\
\text { waste- } \\
\text { water }\end{array}$ & Total & $\begin{array}{l}\text { Agri- } \\
\text { culture }\end{array}$ & $\begin{array}{l}\text { Municipal } \\
\text { and } \\
\text { industrial } \\
\text { losses }\end{array}$ & $\begin{array}{l}\text { Recreation, } \\
\text { energy, and } \\
\text { convey- } \\
\text { ance losses }\end{array}$ & $\begin{array}{l}\text { Total } \\
\text { applied } \\
\text { (or gross) }\end{array}$ & Net \\
\hline$\overline{1949-50^{1}}$ & -- & - & -- & -- & $\ldots$ & 221,900 & 3,700 & -. & -. & 225,600 \\
\hline $1953^{1}$ & 0,000 & -- & -- & .- & -- & -- & .. & _- & _. & 240,000 \\
\hline $1975^{2}$ & 178,700 & -. & - & -- & 192,600 & 166,300 & 26,300 & -- & 192,600 & -- \\
\hline $1980^{3}$ & 82,000 & 4,000 & 78,000 & 4,000 & 168,000 & 205,000 & 40,000 & 1,000 & 246,000 & 168,000 \\
\hline $1985^{3}$ & 103,000 & 4,000 & 41,000 & 4,000 & 152,000 & 115 & 47,000 & 5,000 & 167,000 & 152,000 \\
\hline $1988^{4}$ & 69,000 & 4,000 & 41,000 & 4.000 & 118.000 & & 62,000 & 5,000 & 137,000 & 118,000 \\
\hline $1989^{5}$ & 53,000 & 4,000 & 55,000 & 6,000 & 118,000 & 49 , & 90,000 & 5,000 & 144,000 & 118,000 \\
\hline $1989^{6}$ & 71,018 & 4,318 & ${ }^{7} 50,405$ & ${ }^{8} 4,835$ & 130,576 & 48,843 & 81,733 & -- & 130,576 & -. \\
\hline 199 & 66,707 & 2,165 & 753,087 & ${ }^{8} 6,038$ & 127,997 & & 82,200 & -- & & .- \\
\hline & 1,743 & 669 & 27,396 & & 127 & 35,279 & 92,082 & -- & 127,361 & -- \\
\hline \multicolumn{11}{|c|}{ Historical Projections } \\
\hline$\overline{2000}$ & -- & -- & $\because$ & - & 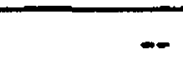 & 1 & 133,400 & - & 29 & - \\
\hline & -. & - & -- & -- & -- & 165,000 & 90,000 & -- & 255,000 & - \\
\hline \multicolumn{11}{|c|}{ Recent Projections by California Department of Water Resources } \\
\hline 2 &, 000 & 4,000 & 87,000 & 7,000 & 145,000 & 64,000 & 104,000 & 7,000 & & 145,000 \\
\hline & & 5.000 & 000 & & 127.000 & & 115,000 & & & 127,000 \\
\hline & 50,000 & 5,000 & 108,000 & 2,000 & 165,000 & 4,000 & 153,000 & 8,000 & 246,000 & 165,000 \\
\hline
\end{tabular}

${ }^{1}$ California Department of Public Works, (1955, p. 20 and 23).

${ }^{2}$ California Department of Water Resources (1980, p. 11 - 16).

${ }^{3}$ California Department of Water Resources (1988, p. 37).

${ }^{4}$ California Department of Water Resources (1990a, p. 21).

${ }^{5}$ California Department of Water Resources (1991b p. 19).

${ }^{6}$ U.S. Geological Survey water-use data bases, May 1994.

7The volumes reported for State Water Project imports include only that part of the delivery to the contractors in the Antelope Valley that was delivered to water users in the Antelope Valley defined in this study. Antelope Valley-East Kern Water Agency supplies water to water users in communities outside of the study-area boundary.

${ }^{8}$ This number is the sum of reclaimed wastewater that was used for agricultural irrigation, wetlands maintenence, and recreational water uses.

${ }^{9}$ This number is the sum of ground water pumped by public suppliers (45,208 acre-feet), self suppliers for their own use (30,877 acre-feet), and self suppliers who sold water to Antelope Valley-East Kern Water Agency to supplement State Water Project imports that were not received because of the drought (15,658 acre-feet).

${ }^{10}$ California Department of Water Resources (Verne Knoop, written commun., preliminary data for Bulletin 160-93, 1993). Total applied water demand for 2010 and 2020 from California Department of Water Resources (1993a, p. 260 and 263).

aberration during data recordation created an artificially low annual total for reported use of water supplies in 1988. Since then, annual total reported use of water supplies peaked in 1989 at 130,000 acre- $\mathrm{ft}$ and then declined slightly to about 128,000 in 1990 and 127,000 acre-ft in 1991 (fig. 8).

A comparison of the data base developed for this study with published information indicates differences in total reported annual water use between 10 percent and 35 percent. For example, total reported water use from this data base for the Antelope Valley was 130,576 acre-ft in 1989 (tables 2 and 3); the California Department of Water Resources $(1991$, p. 19) reported that total water use was about 118,000 acre-ft (table 2). This comparison indicates a need for coordination of water-use data from individuals and agencies at all levels of government. This coordination already has begun for the Antelope Valley with the completion of this study and the development of the data base that is continuing through the efforts of the Antelope 


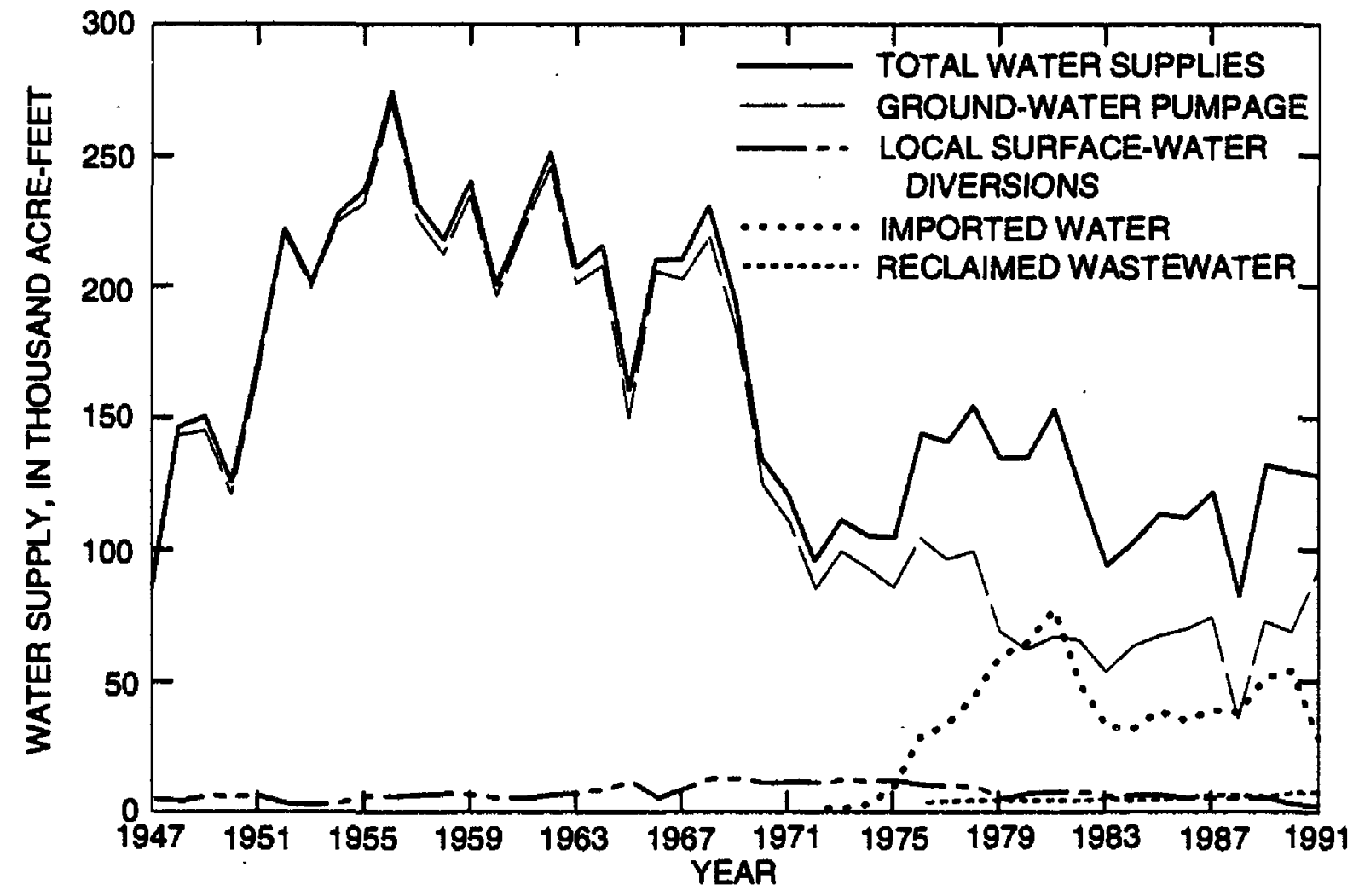

Figure 8. Total water supplies for the Antelope Valley for 1947-91 from the data base developed for this study. Historical ground-water pumpage data were available primarily for the Los Angeles County part of the valley; therefore, these estimates of total water supplies are low. useable ground-water-storage capacity and of remaining total ground-water storage is needed for the Antelope Valley.

Use of available groundwater supplies from aquifers typically is quantified as withdrawals from groundwater sources (also referred to as ground-water pumpage). The period of record for ground-water pumpage, compiled for this report from various published sources, starts in 1919 and continues through 1990 (fig. 9, table 4). Estimates of groundwater pumpage in 1951, which were based on records of electrical power use and consumptive use, ranged from about 400,000 acre-ft (gross) to 149,000 acre-ft (net)
Valley Water Group. Since 1991, coordination of water-use information also has begun statewide through efforts of the U.S. Geological Survey and the California Department of Water Resources. A statewide interagency water-use coordination committee was formed. The committee has four actively working subcommittees that deal with the coordination and improvement of information on land use, ground-water use, urban water use, and agricultural water use. Similar groups could be formed in the Antelope Valley to help improve information sharing and increase information reliability and completeness.

\section{Ground-Water Supply}

Historically, the ground-water-storage capacity for the Antelope Valley was estimated to be 68 million acre-ft; in 1975, total ground water remaining in storage was estimated to be 55 million acre-ft (California Department of Water Resources, 1980, p. 25). Snyder (1955) estimated that ground water, available in storage in 1954, would last 35 to 65 years, depending on the rate of growth in the area. Useable storage was estimated to be 20 million acre-ft on the basis of 1980 data (California Department of Water Resources 1993a, table 4-2). An updated (possibly more accurate) estimate of
(Snyder, 1955, p. 64). Snyder (1955, p. 68) described net pumpage to be the consumptive-use part of the total applied water. He assumed irrigation efficiency to be about 50 percent; thus 149,000 acre-ft net is equal to 298,000 acre-ft gross. More water may actually have been consumptively used than Snyder assumed because much of the water he assumed was recharging ground water may have been retained in the unsaturated zones above the useable ground water. Ground-water-quality data (Duell, 1987) also support the idea that Snyder's consumptive-use estimate may have been low because the data do not indicate increased salinity following the peak irrigation years. Increased salinity would be expected if about 50 percent of the applied water actually were recharging the aquifer.

Ground-water pumpage values from the California State Water Resources Control Board (State Board) for the late 1940's and early 1950's are much lower than those estimated by Snyder (1955). In 1951, for example, the California State Water Resources Control Board estimated that ground-water pumpage was about 165,000 acre-ft compared with about 400,000 acre-ft estimated by Snyder (1955). This large discrepancy probably is a result of significant underreporting of water use to the State Board at that time and the fact that Kern County was not included in the State Board data base. 
Tabie 3. Selected water-use Information by water suppller and water-supply sources summarized from data bases created for Antelope Valley, 1989-91

[Imported water represents water purchased from State Water Project contractors by water suppliers within this study-area boundary for the Antelope Valley]

\begin{tabular}{|c|c|c|c|c|c|}
\hline \multirow[b]{2}{*}{ Water supplier } & \multicolumn{4}{|c|}{ Water-supply source, in acre-feet per year } & \multirow[b]{2}{*}{$\begin{array}{l}\text { Total } \\
\text { water } \\
\text { supply }\end{array}$} \\
\hline & $\begin{array}{l}\text { Ground } \\
\text { water }\end{array}$ & $\begin{array}{c}\text { Local } \\
\text { surface } \\
\text { water }\end{array}$ & $\begin{array}{l}\text { Imported } \\
\text { water }\end{array}$ & $\begin{array}{l}\text { Reclaimed } \\
\text { waste- } \\
\text { water }\end{array}$ & \\
\hline \multicolumn{6}{|c|}{1989} \\
\hline $\begin{array}{l}\text { Public supplied } \\
\text { Self supplied }\end{array}$ & $\begin{array}{l}43,098 \\
27,920\end{array}$ & $\begin{array}{l}1,191 \\
3,127\end{array}$ & $\begin{array}{l}32,609 \\
17,796\end{array}$ & $\begin{array}{r}4,835 \\
0\end{array}$ & $\begin{array}{l}81,733 \\
48,843\end{array}$ \\
\hline Total & 71,018 & 4,318 & 50,405 & 4,835 & 130,576 \\
\hline \multicolumn{6}{|c|}{1990} \\
\hline $\begin{array}{l}\text { Public supplied } \\
\text { Self supplied }\end{array}$ & $\begin{array}{l}39,400 \\
27,307\end{array}$ & $\begin{array}{r}46 \\
2,119\end{array}$ & $\begin{array}{l}36,716 \\
16,371 \\
\end{array}$ & $\begin{array}{r}6,038 \\
0 \\
\end{array}$ & $\begin{array}{l}82,200 \\
45,797 \\
\end{array}$ \\
\hline Total & 66,707 & 2,165 & 53,087 & 6,038 & 127,997 \\
\hline \multicolumn{6}{|c|}{1991} \\
\hline $\begin{array}{l}\text { Public supplied } \\
\text { Self supplied }\end{array}$ & $\begin{array}{r}45,208 \\
146,535 \\
\end{array}$ & $\begin{array}{r}36 \\
1,633 \\
\end{array}$ & $\begin{array}{r}24,627 \\
2,769 \\
\end{array}$ & $\begin{array}{r}6,553 \\
0 \\
\end{array}$ & $\begin{array}{l}76,424 \\
50,937 \\
\end{array}$ \\
\hline Total & 91,743 & 1,669 & 27,396 & 6,553 & 127,361 \\
\hline
\end{tabular}

'In 1991, 15,658 acre-feet of ground water was pumped by private well owners included in our self-supplied data bases. This water was sold to Antelope Valley-East Kern Water Agency (see footnote 2). To avoid double accounting in this table, this volume is included in the ground-water column for "Self-supplied water" because it came from ground-water supplies. In table 8 of this report, the 15,658 acre-feet in 1991 is shown in the column for "Imported water" because that table emphasizes water use.

${ }^{2}$ For 1991 , this number is lower by 15,658 acre-feet than is reported in table 8 because this table emphasizes water-supply sources; in table 8, emphases is on the location of the water used. In 1991, water was pumped from self-supplied wells and sold to the Antelope Valley-East Kern Water Agency to supplement shortages in deliveries to public water suppliers because of the drought.

Water supplies obtained from ground-water sources also have been estimated by the California Department of Public Works (1955, p. 20; California Department of Water Resources, 1980, p. $17 ; 1990 \mathrm{a} ; 1991 \mathrm{~b})$ at about 480,000 acre-ft in $1953 ; 178,700$ acre-ft in $1975 ; 58,000$ acre-ft in 1980 and 1985; 69,000 acre-ft in 1988; and 53,000 acre-ft in 1989 (table 4).

Some problems were identified when we compared published estimates of ground-water pumpage from various sources with reported ground-water pumpage. These problems include

(1) differences in reported volumes of pumpage;

(2) variations in the interpretation of the area within the Antelope Valley boundaries; (3) periods of missing data and data that show no variation from one year to the next, and (4) comparison of water supplies for a larger area than was used for estimating water demands.
Several solutions were implemented for this study to minimize these problems. One solution was development of a common base map that delineated the most widely accepted border for the drainage basin for the Antelope Valley. This basin boundary compares well with the boundaries used by Bloyd (1967), Duell (1987), and the California Department of Water Resources. However, the boundary used by Durbin (1978) differs substantially from all other studies of the valley because it was based on the assumption (for modeling purposes) that no flow crosses a fault along the northern boundary of the study area. Totals for water supply and demand from these studies with similar boundaries should compare well with the totals in this report; totals from Durbin (1978), however, could be expected to be lower.

A second solution implemented to minimize problems with the published aggregated pumpage 


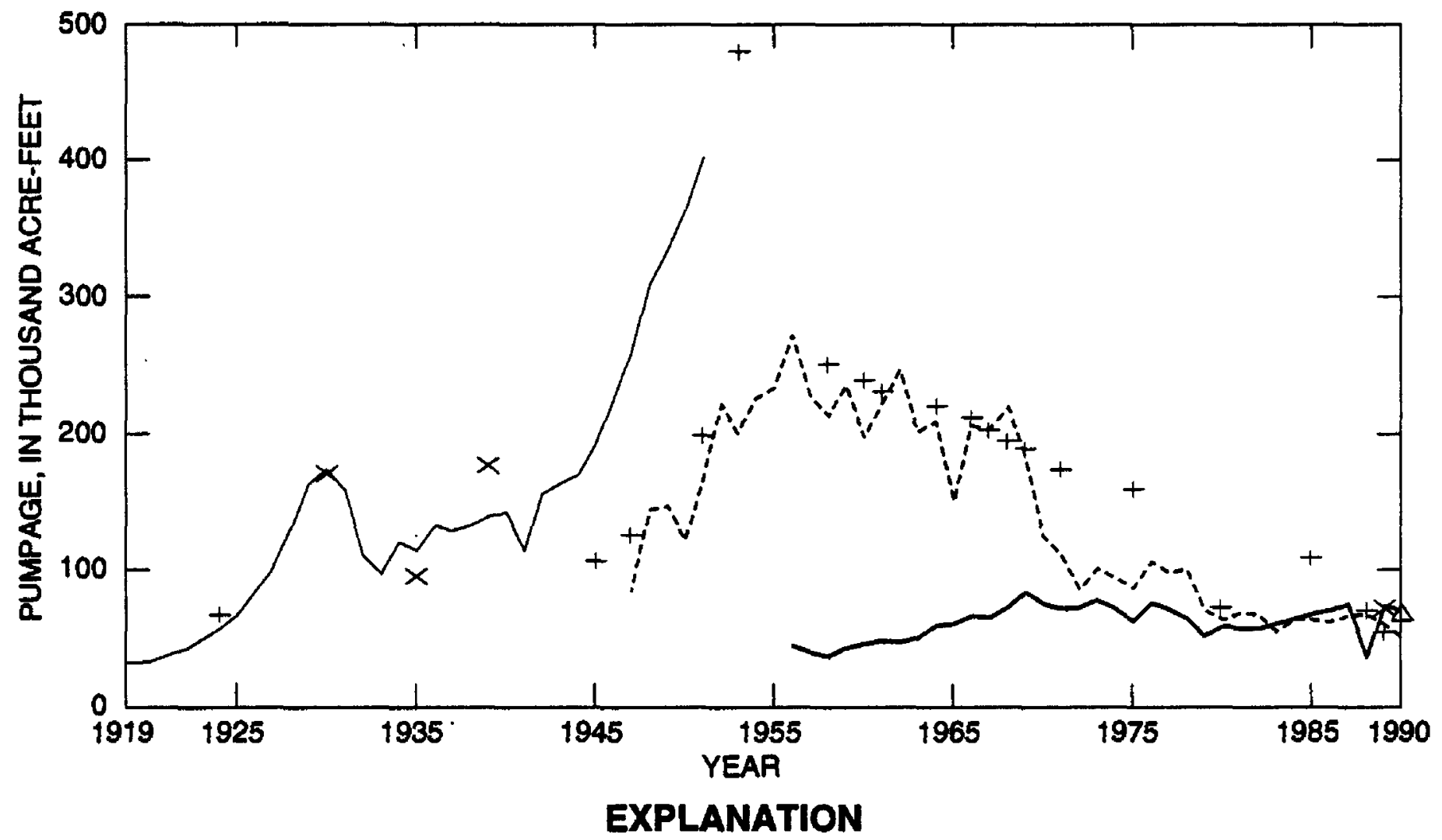

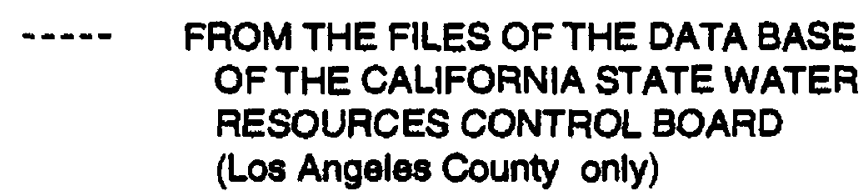

- LAW ENVIRONMENTAL (1991)

SNYDER (1955, p. 62, 64, and 165) $+\quad$ CALIFORNIA DEPARTMENT OF PUBLIC WORKS (1955, p. 28); CALIFORNIA DEPARTMENT OF WATER RESOURCES (1980; 1990a; 1991b)

$\times \quad$ MANN (1989)

$\triangle \quad$ ANTELOPE VALLEY UNITED WATER PURVEYORS (written commun., 1991)

Figure 9. Historical published estimates of grourid-water pumpage for the Antelope Valley.

data in the study area was to develop a computerized ground-water pumpage data base categorized by water user and by method of supply (either self supplied or public supplied). Users who supply their own water are classified as self-supplied users; users who are supplied by a government or private entity are classified as public-supplied water users. This ground-water pumpage data base includes partial data for 1946-92, but because the data are severely limited for 1946 and 1992, 1947 to 1991 was used as the period of record (fig. 10). In 1987, the quantity of water withdrawn by public suppliers exceeded the quantity withdrawn by self suppliers for the first time (fig. 10), indicating that municipal use of ground water had begun to exceed agricultural use. A summary of the data base for 1989-91 indicates ground-water pumpage accounted for 71,$018 ; 66,707$; and 91,743 acre-ft in 1989, 1990, and 1991, respectively (table 3 ). Although the ground-water pumpage data base from the California State Water Resources Control Board is limited to wells in the Los Angeles County and San Bernardino parts of the Antelope Valley, it is the best data available for use in developing a complete data base for ground-water pumpage from wells.
The data base used for this study was developed using the original data reported by well owners to the State Board, augmented by pumpage records of individual public water suppliers, as well as water sources and uses reported to the California Department of Water Resources. Land-use information and power-consumption data often can be used to assure the completeness of a ground-water data base. In the Antelope Valley, indications of urban and agricultural land-use information (from all sources in this report) compared favorably with our data base. Power-consumption data could not be used to estimate pumpage for comparison because the locations of the power meters were not available. Additional improvements in estimates of historical agricultural water demand may still be possible using land-use and power-consumption data. However, these improvements could require a substantial investment of time and resources.

Total reported ground-water pumpage for the Los Angeles County part of the Antelope Valley peaked in 1956 at about 270,000 acre-ft (fig. 8). This peak was followed by a gradual decrease in pumpage until 1968, with reported pumpage only 


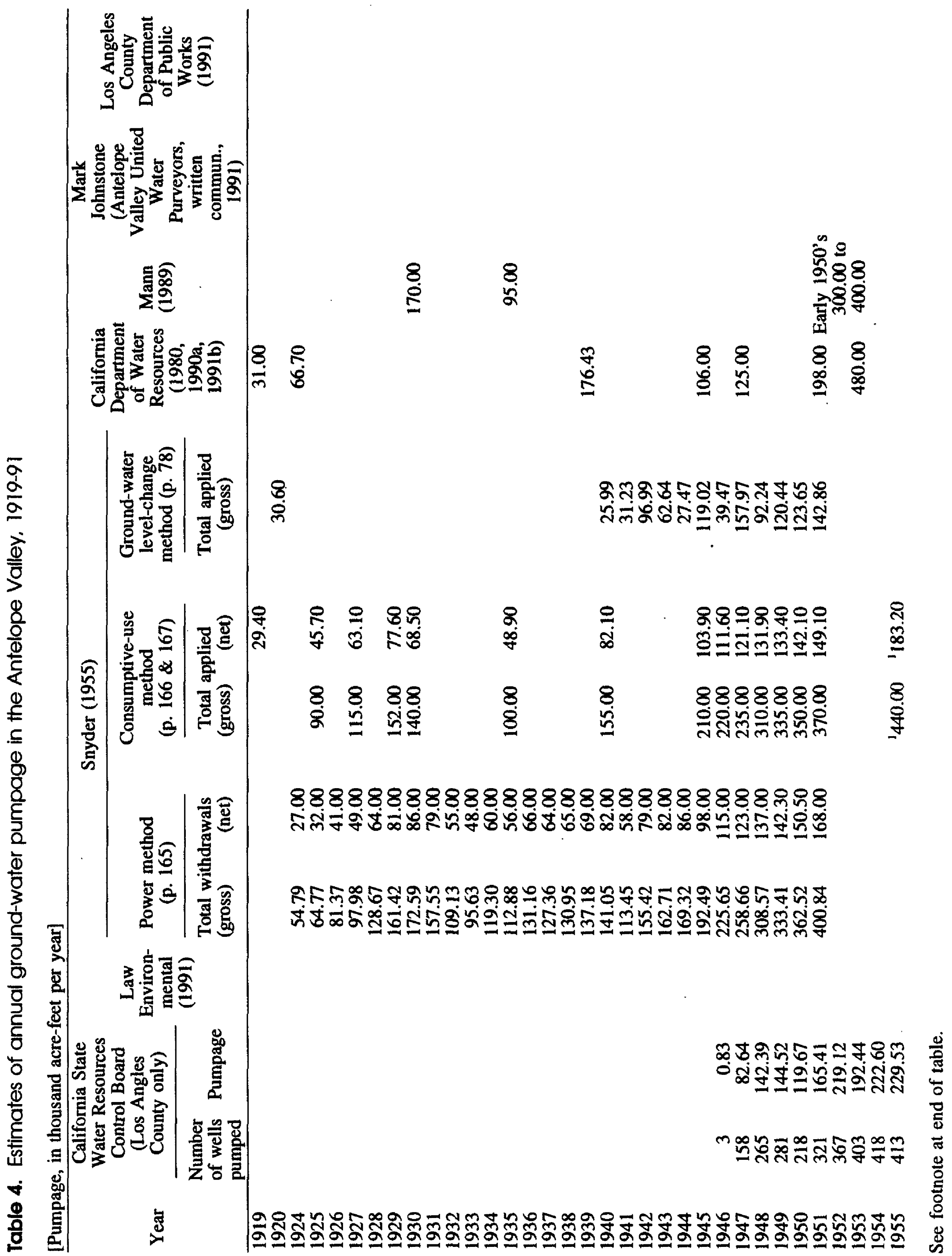




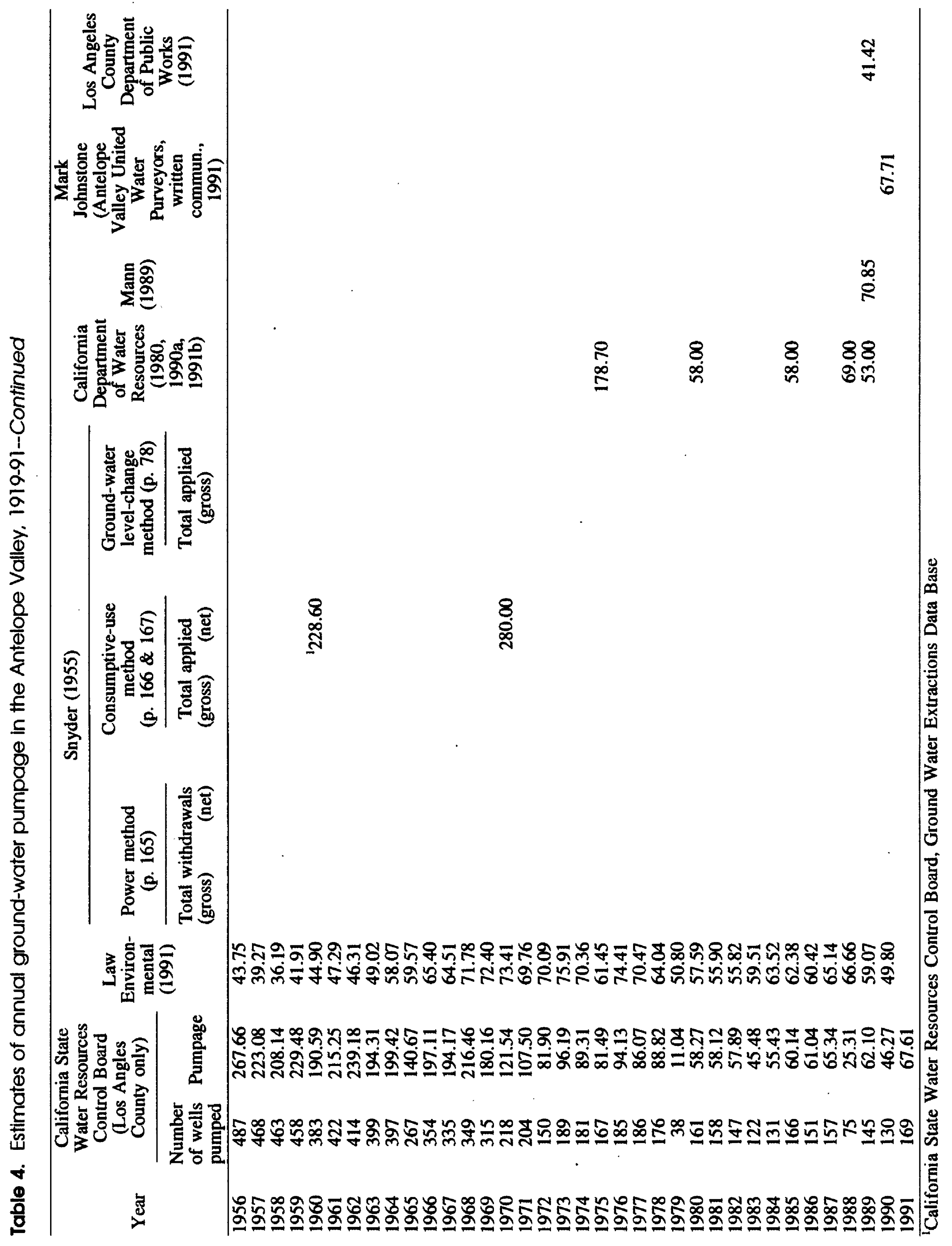




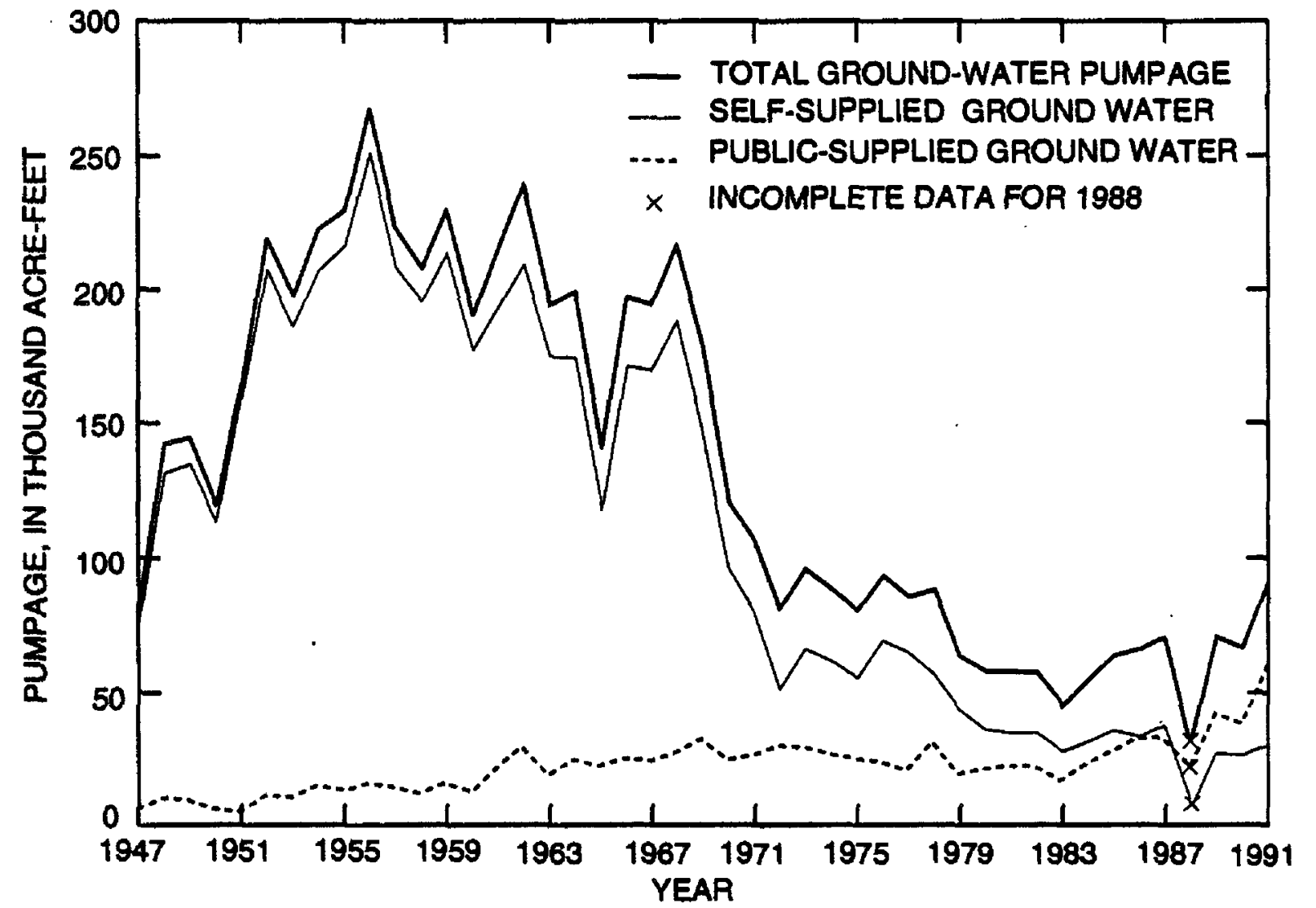

Figure 10. Ground-water pumpage from data base developed for this Antelope Valley study, 1947-91.

about 219,000 acre-ft. Between 1968-72, reported pumpage decreased dramatically, reaching a low of about 85,000 acre-ft/yr just before imported water from the State Water Project became available. The decrease in ground-water pumpage then became more gradual, reaching a low of about 53,200 acre$\mathrm{ft}$ in 1983. Since 1983, reported pumpage has increased. In recent years, which were characterized by rapid urban growth and drought, between 50 and 90 percent of total annual water demands in the Antelope Valley was from ground-water pumpage. In 1991, when little imported water was available, total pumpage was about 91,743 acre-ft.

The first year for which reported ground-water pumpage data acquired for the Kern County part of this study area was 1947 for Edwards Air Force Base, 1989 for Mojave and Rosamond, and 1958 for the Boron area. The lack of reported pumpage data for Kern County represents a significant omission in estimated pumpage, particularly for the 1950's and 1960's.

Edwards Air Force Base, the town of Mojave, and the U.S. Borax and Chemical Corporation account for most of the ground water presently. (1994) used in the Kern County part of the Antelope Valley. Reported pumpage (table 18 at back of report) at Edwards Air Force Base increased from about 600 acre-ft in 1947 to about
6,700 acre-ft in 1965 and remained at about 6,000 acre$\mathrm{ft} / \mathrm{yr}$ until 1967. Pumpage data is missing for the period 1968 through 1975 (R.F. Weston, Inc., 1986; 1988). Between 1976 and 1990, annual pumpage at Edwards Air Force Base decreased from about 6,300 acre-ft to about 5,330 acre-ft (table 18 at back of report). In 1991 and 1992, reported pumpage decreased further to 3,700 and 3,400 acre-ft/yr, respectively. Mojave accounted for about 1,200 to 1,300 acre$\mathrm{ft} / \mathrm{yr}$ of pumpage during 1989-91. Annual pumpage for U.S. Borax and Chemical Corporation peaked at about 3,000 acre-ft in 1977 and decreased to about 1,200 acre-ft by 1991 , partly due to use of imported water from the State Water Project.

Comparisons between published annual historical water use for the Antelope Valley (Califomia Department of Water Resources, 1991b) and the data base developed for this study indicate the following differences. Reported withdrawals from ground-water supplies for 1989 were 53,000 acre-ft compared with 71,018 acre-ft in our data base (tables 2 and 4). These results indicate that the total for ground-water withdrawals contained in the data base for this study are 34 percent higher than the published net for ground-water withdrawals. Data compiled for 1991 show that ground-water use increased 29 percent to 91,743 acre-ft in just 2 years, indicating that dramatic changes in water use can occur in a short period of time. There is a great potential for error if close attention is not paid to (1) annual monitoring of available water-supply information and (2) quality assurance of pumpage reported by users to the State Board.

Presently (1994), estimates of total ground-water pumpage included in the data base developed for this study are low because our data base is still incomplete for some water users and for some years throughout the period of record. Historically, not all users are included in the State Board data base for every year; as a result, totals from our data base are low. Data are severely limited for Kern County water users for much of the period of record. Data 
were found as part of our augmentation of the State Board's data base for some water users in the Kern County part of the Antelope Valley. Data obtained from the State Board's computer files included only reported pumpage from wells in four California counties: Los Angeles, San Bernardino, Ventura, and Riverside. However, only Los Angeles and San Bernardino County wells within the study area were retained from the original data base extracted for the Antelope Valley.

The lack of reported ground-water pumpage data for Kern County for earlier years represents significant errors or omissions in estimates of historical ground-water pumpage. To help reduce these errors, Kern County pumpage can be estimated on the basis of irrigated acreage if we assume that the water requirements of crops planted in Kern County were similar to crops planted in Los Angeles County. Using crop acreages for the parts of Kern County and Los Angeles County within our study area in 1953 (table 1) and reported self-supplied ground-water pumpage in Los Angeles County during 1953 (fig. 10), we estimated total ground-water pumpage for the entire Antelope Valley for 1953. Using this method, our estimate of total ground-water pumpage for the Antelope Valley during 1953 increased from the reported 192,000 to 308,000 acre-ft. Using this correction factor, based on the 1953 data and the peak groundwater pumpage reported for the Los Angeles County part of the Antelope Valley (267,660 acre$\mathrm{ft}$, table 4), total ground-water pumpage for the entire Antelope Valley was estimated to have been about 429,000 acre- $\mathrm{ft}$ in 1956. This valleywide pumpage estimate is consistent with previous estimates of 400,000 acre- $\mathrm{ft} / \mathrm{yr}$ by Snyder (1955) and 480,000 acre-ft/yr by the California Department of Public Works (1955, p. 20).

\section{Pumpage totals for wells in the Los Angeles} County part of the study area do not appear to have been reported by registered well owners for every year that ground water probably was pumped. The incompleteness of the data base is caused, in part, by the State-imposed deadline of June 30 for reporting ground-water pumpage totals. Pumpage data from Recordation Notices received by the State Water Resources Control Board that were postmarked after that date were not entered for some years. Commonly, these data are kept in the State hard-copy files and we have entered them into our data base; but, for at least 1 year (1988) late reports were returned to the well owners and thus were not readily available. The effects of incomplete data can be seen on figure 10. Methods used to estimate pumpage also can influence the reliability of these estimates. For example, information pertaining to the methods that were used by each well owner to estimate their reported pumpage is noted on some of the completed Recordation Notice forms. We used this information as an indication of the accuracy of the pumpage estimates for some of the reporting water users. Some users report the methods they use to estimate their pumpage, but most users do not. For quality assurance, verification that the methods used for reported ground-water pumpage are appropriate and used accurately still needs to be done. Our observation that identical amounts of pumpage have been reported year after year by some wells owners indicates the need for closer quality assurance.

Estimates of ground-water pumpage included in the original State Board data base also may be inflated in some cases because well owners have anticipated the potential to use this data base to establish generous future water rights. In various parts of the Nation, such as Kansas (Kenny, 1986, p. 3), it is a common practice for water users to overestimate rather than underestimate their reported water use to establish future water rights.

Commonly, this is done to establish a higher record of water use than actually might have occurred. However, ground-water pumpage estimates that might be represented by overreporting are not expected to approximate the ground-water pumpage that is historically absent for the Kern County area. Therefore, total ground-water pumpage in our data base is expected to be low.

The same methods used to estimate groundwater pumpage commonly are used to estimate water demand (table 4). Four methods for estimating pumpage have been used in the Antelope Valley: the power method, the consumptive-use method, the ground-water-level change method, and the flow-totalizing meter method. Pumpage between 1919-51 was estimated by Snyder (1955) using the first three methods. Snyder (1955) concluded that the power and consumptive-use methods were reliable, but results from the groundwater-level change method should be rejected because there were not enough wells in the waterlevel network to provide reliable results. For 1950, Snyder's (1955) estimates were about 362,000 acreft using the power method and about 350,000 acre$\mathrm{ft}$ using the consumptive-use method. In comparison, pumpage reported to the California State Water Resources Control Board for 1950 was about 
120,000 acre-ft (some of which was reported from metered municipal wells). The disparity in these numbers probably is because of extensive underreporting at that time and the lack of recordation data for Kern County.

The strengths and weaknesses of the power, consumptive-use, and ground-water-level change methods are well documented by Snyder (1955). Although Snyder (1955) rejected the groundwater-level change method, this method may be more reliable now (1994) than it was at the time of Snyder's study because more wells are monitored for water-level changes now than were monitored during the study by Snyder. However, a detailed statistical network analysis is needed to determine the adequacy of the existing network for the objective of estimating net ground-water pumpage. Use of the power method can result in an underestimate of ground-water pumpage if only electrical power is used because many of the wells may be powered by diesel or other fuels. Lack of available information on pump efficiencies and depths to water when wells are pumping also limits the accuracy of pumpage estimates using this method. Weakness in the consumptive-use method occurs because other uses of water, such as for weed control, leaching soil salts, frost protection and preirrigation to moisten dry soils, are not considered. Acreage data, irrigation efficiency, crop-water demands and applied water for each crop type usually are not available for all crops every year. When using the consumptive-use method, inaccuracies in estimates of annual water use are generated when the data used in making these estimates are not updated annually. This method also may produce high estimates if deficit irrigation is practiced as we noticed in our land-use study in the Antelope Valley in 1992

Confusion between "applied" water and "net" water can occur when estimates of total withdrawal are made using the consumptive-use method. Typically, the difference between "applied" water and "net" water is the amount of water that is applied that exceeds the amount of water required to meet the demand of the water user at the point of use. More water must be withdrawn from whatever sources are available than is required to meet the historical demand for any specific use at the point of use because no delivery system, water-supply system, irrigation application system, toilet, or most any kind of water-use system is 100 percent efficient. "Net" water use also can be described as that part of applied water that is consumptively used (evaporated or evapotranspired) or irrecoverably lost from the distribution system and agricultural return flow or treated municipal wastewater outflow (California Department of Water Resources, 1993a, p. 141).

To understand the meaning of "net" water demand, it is necessary to comprehend that not all of the water applied to a field or lawn can be used by the vegetation or absorbed by the soil. This excess water can become irrigation return flows, runoff from lawns, returns to sewers, or contributions to moisture-deficient soil. How much of this excess water actually goes to each of these uses is difficult to quantify. However, if the consumptive-use method is to be used to estimate total withdrawals from available water sources (surface water, ground water, or reclaimed water), some educated guesses must be made for each of these additional uses of water. Annual and seasonal variations in irrigation efficiency, effective precipitation, and crop-water demand because of wind and temperature variations also limit the accuracy of the consumptive-use method. Metering usually is considered the most reliable method for estimating water use (including ground-water pumpage); but, if the meters are not well maintained or installed correctly, even this method can be unreliable. One of the most effective approaches for improving estimates of water use for any area is to identify all major water users, expand the knowledge about the available methods of water-use estimation, and enhance the availability of the data needed to make the estimations.

One of the most significant limitations of this study is the lack of knowledge about the total number of wells that have pumped ground water each year in the valley. Many wells were abandoned because of casing failure owing to land subsidence and because of the decreases in agricultural activity. A comparison between historical land-use maps and the distribution of wells was used to help verify the completeness of our data base for years when maps were available. Sitespecific locations, which can be plotted using a computer, are not available for all wells in our pumpage data base. However, site-specific locations are available for many wells included in the U.S. Geological Survey Ground Water Site Inventory data base (fig. 11). This data base indicates that there have been at least 3,723 different wells in the study area at some point in time; however, the number of wells that were active in any given year is not known. Annual land-use 


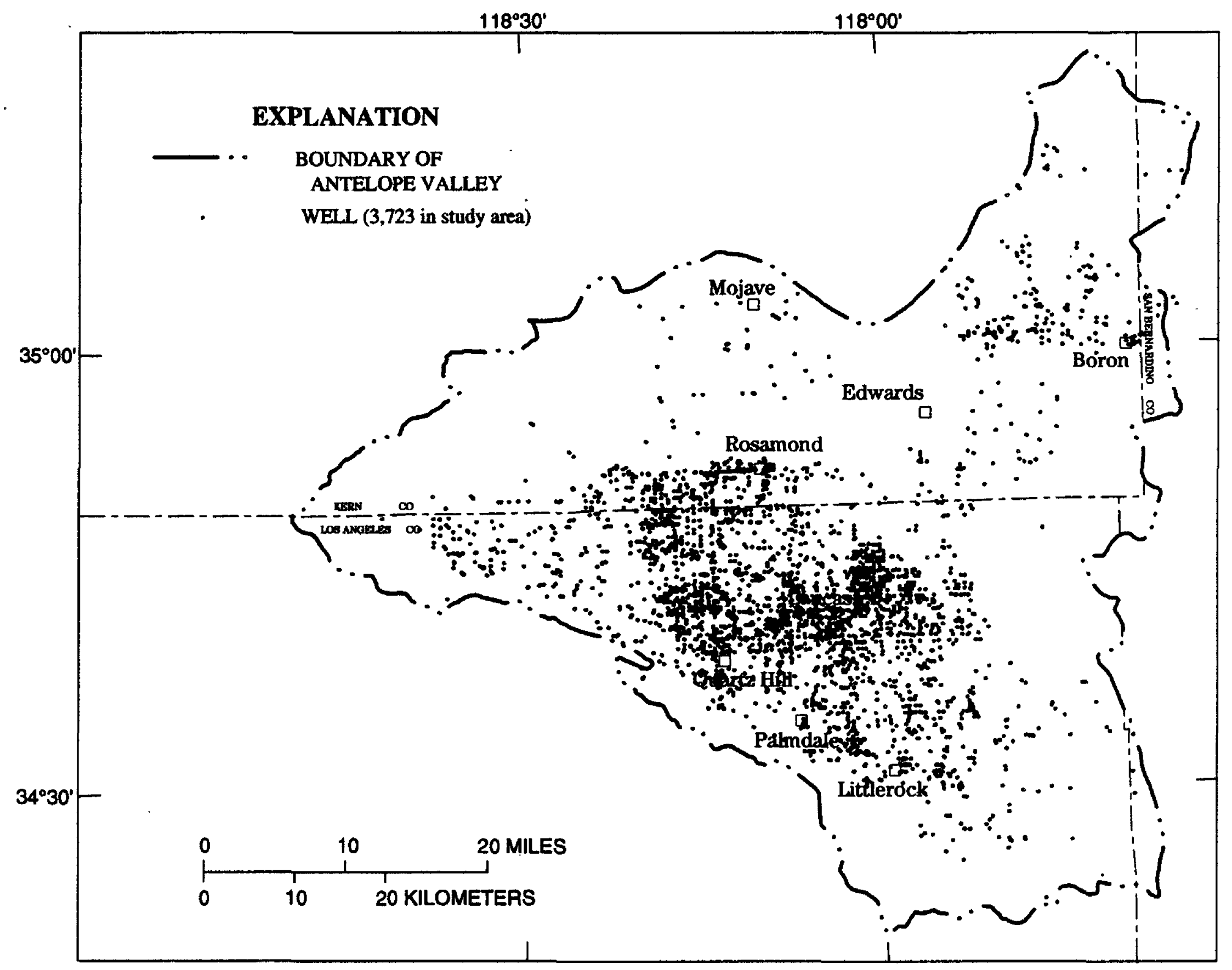

Figure 11. Locations of wells in the Antelope Valley. (Source: U.S. Geological Survey, Ground Water Site Inventory Data Base in WATSTORE.)

maps (or remotely sensed images), a detailed canvas of wells, and historical records of power use (if such information exists) could be valuable in determining the number of wells that were actively pumping each year.

Annual ground-water pumpage has been reported to the California State Water Resources Control Board for only 906 individual wells from 1947 through 1991. The highest total annual pumpage was about 268,000 acre-ft in 1956 for 487 wellsthe most wells reported for any single year (table 4 , fig. 9). All 487 wells were in the Los Angeles County part of the Antelope Valley. Owners of wells in Kern County are not required to report pumpage to the California State Water Resources Control Board. A complete data base of all active wells, with site-specific locations and metered monthly pumpage, is needed.
Since 1980, annual pumpage for about 100 to 200 wells has been reported to the California State Water Resources Control Board. On the basis of the U.S. Geological Survey Ground Water Site Inventory data base (fig. 11), there were many more wells that could have been active in the Antelope Valley than the 906 wells for which some of the annual pumpage was reported to the California State Water Resources Control Board for 1946-91.

Comparison between water-district boundaries (fig. 12) and recent land-use information (fig. $5 B$ ) indicates that self-supplied water use in 1992 may be minimal in the Kern County part of the Antelope Valley. Therefore, the self-supplied water users whose water came from wells in 1992 in the Kern County part of the study area may not account for much water use. 


\section{EXPLANATION FOR FIGURE 12}

\begin{tabular}{|c|c|}
\hline $\begin{array}{l}\text { ANTEL } \\
\text { DISTRI } \\
\text { MAP N }\end{array}$ & $\begin{array}{l}\text { E VALLEY WATER } \\
\text { LOCATIONS } \\
\text { IBER }\end{array}$ \\
\hline 1 & 16th Street West Tract \\
\hline 2 & Antelope Park Mutual Water Company \\
\hline 3 & Antelope Valley Water Company, Lancaster District \\
\hline 4 & Antelope Valley Water Company, Leona Valley District \\
\hline 5 & Averydale Mutual Water Company \\
\hline 6 & Baxter Mutual Water Company \\
\hline 7 & Boron Community Services District \\
\hline 8 & Brierwood Mobile Home Estates \\
\hline 9 & Edwards Air Force Base Water Service Area \\
\hline 10 & El Dorado Mutual Water Company \\
\hline 11 & Evergreen Water Company \\
\hline 12 & Hidden Valley Mntual \\
\hline 13 & Los Angeles County Waterworks District, Number 4 \\
\hline 14 & Los Angeles County Waterworks District, Number 24 \\
\hline 15 & Los Angeles County Waterworks District, Number 27 \\
\hline 16 & Los Angeles County Waterworks District, Number 33 \\
\hline 17 & Los Angeles County Waterworks District, Number 34 \\
\hline 18 & Los Angeles County Waterworks District, Number 35 \\
\hline 19 & Los Angeles County Waterworks District, Number $38 \mathrm{I}$ \\
\hline
\end{tabular}

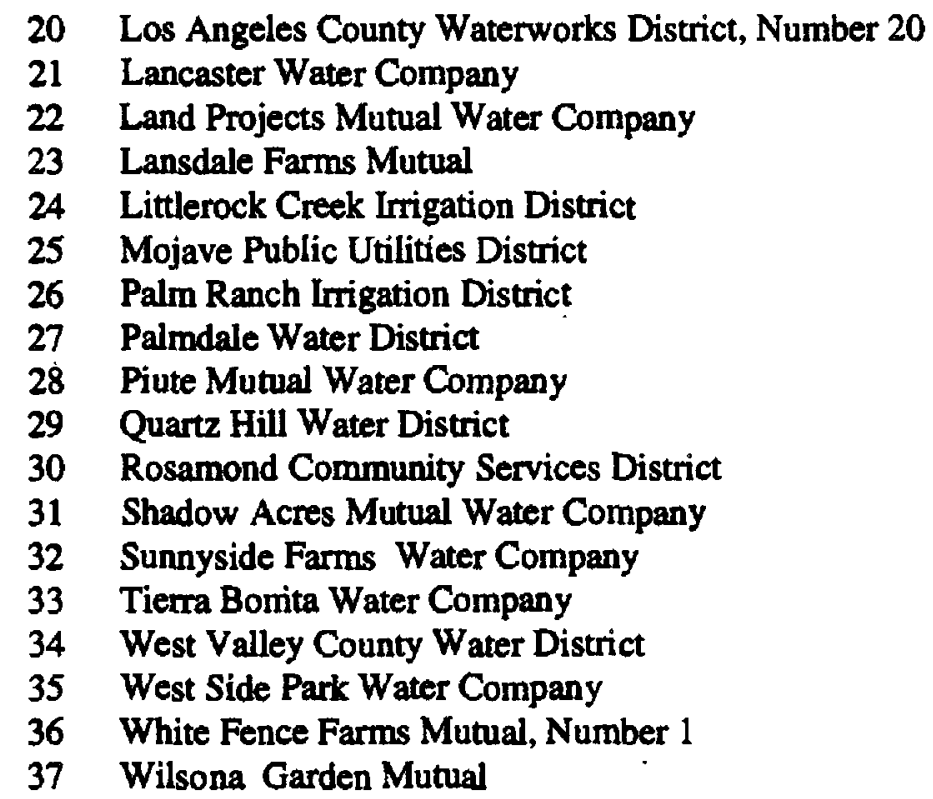

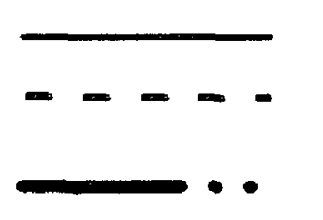

CALIFORNIA AQUEDUCT

ANTELOPE VALLEY-EAST KERN

DELIVERY SYSTEM

BOUNDARY OF ANTELOPE VALLEY

\section{Surface-Water Suppiy}

\section{Locai Surface-Water Resources}

The close association between rainfall and runoff allows the use of rainfall to help review runoff conditions that have been experienced locally. Flow in the streams that enter the Antelope Valley are heavily influenced by rainfall and other related precipitation (such as snowfall in the higher elevations). The following discussion of local precipitation characteristics provides clues that are useful in understanding natural runoff that is available locally.

Mean annual precipitation in the valley was calculated using rainfall records available at the time of the study by Rantz (1969). These records indicate that precipitation rates are more than 12 in/yr in the surrounding mountains along the southern boundary of the study area and as low as about $5 \mathrm{in} / \mathrm{yr}$ along the northern boundary. Precipitation maps vary significantly in appearance depending on the period of record and the number of rainfall gages used, as well as the variation in rainfall distribution (Templin and Schluter, 1990, p. 34). A more recent report on mean annual precipitation
(Blodgett and Nasseri, 1993, p. 11) confirms these areas with similar high and low precipitation rates, but indicates that mean annual precipitation ranges from 24 in. (in the mountains in the southeastern part of the study area) to less than 5 in. (near the northeastern border of the valley). Precipitation often is concentrated in localized areas (Blodgett and Nasseri, 1993, p. 11). Knowledge of these localized precipitation patterns can be used to enhance the capture and use of local runoff. Improvement in the collection of data for localized precipipitation trends, and the associated runoff in streams, can provide local water-resource managers the information needed to make decisions. These decisions include design of drainage facilities and improvements in diversion and impoundment facilities in this moisture-deficient area.

Historically, surface-water sources have contributed only a small part of the water supplies used in the Antelope Valley. Reported diversions from surface-water sources peaked in 1968 and totaled almost 12,000 acre-ft but have since decreased to about 2,165 acre-ft in 1990, probably because of drought (fig. 13). Surface-water diversions can be expected to follow rainfall trends. Records of annual total diversions from surface-water sources 


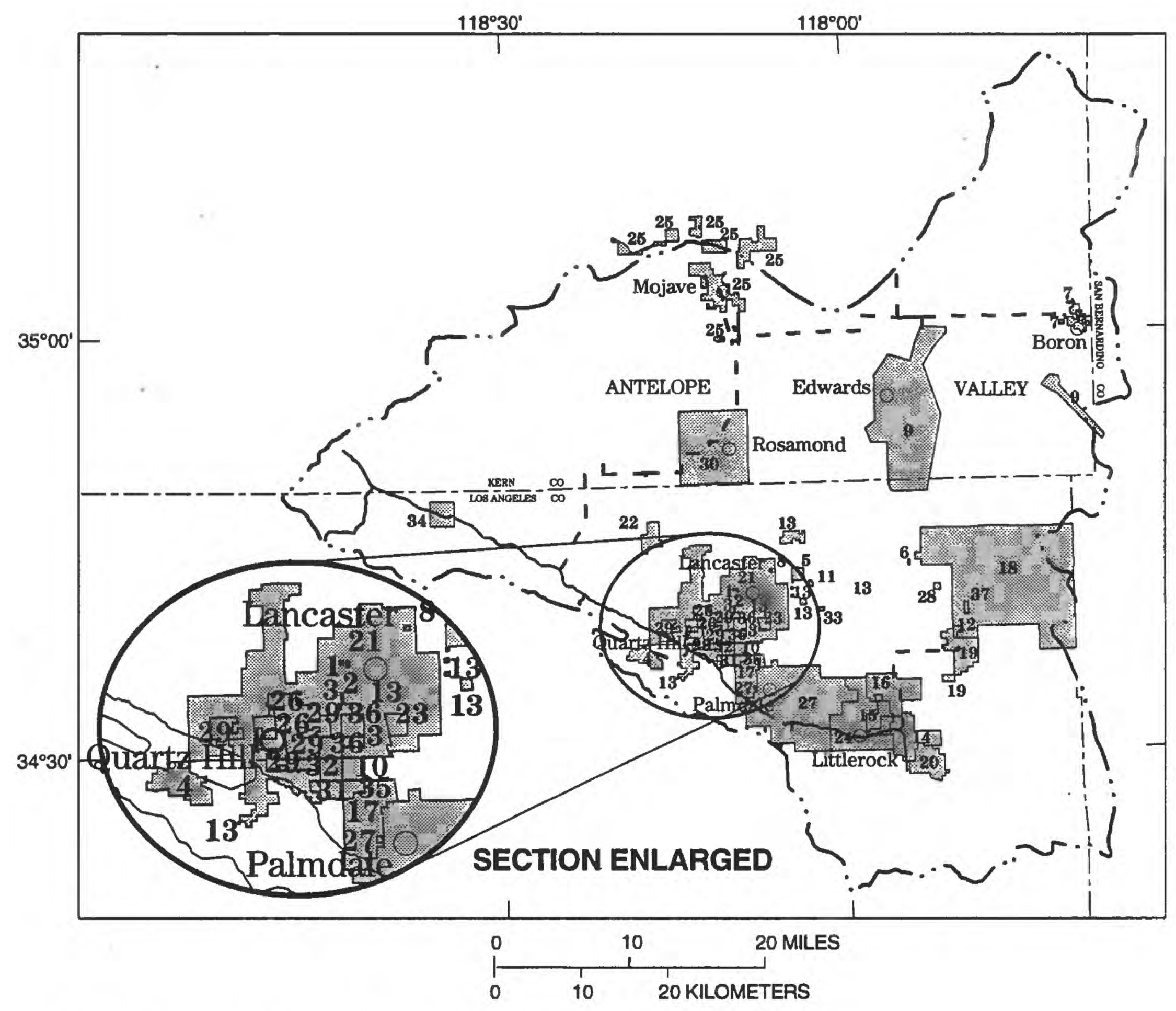

Figure 12. Water-district boundaries in the Antelope Valley.

reported to the California State Water Resources

Control Board, Division of Water Rights, indicate that self-supplied water users withdraw about twice as much water as public suppliers (fig. 13). Comparisons between surface-water diversions over time and precipitation records for various gages in the area (fig. 2) can help assure that the records of reported surface-water diversions are reasonable. Surface-water diversions need to be accounted for when estimating ground-water recharge using stream-discharge data.

In the Antelope Valley, only a few surface-water storage facilities (table 5, fig. 14) retain local runoff for later use. This marginal amount of storage capacity can accommodate only a limited amount of water. Storage of local runoff or imported water could be increased if more facilities were available or if existing facilities had greater storage capacities. These storage facilities could act as additional recharge facilities or as temporary storage for nearby artificial recharge operations to enhance management of water resources in the Antelope Valley. Other surface-water bodies are shown on figure 14 and on the land-use map for 1973-76 (fig. 4) that might have been used for storage of runoff.

Stormwater runoff is a resource that has potential for greater use in the Antelope Valley. Stormwater drains from the surrounding hillsides onto the alluvial fans and flashes down washes until it reaches the valley floor where it ponds on relatively impervious clayey materials until it evaporates. This runoff from intense, short-duration storms represents a resource that is not highly utilized and is difficult to control, as evidenced by 


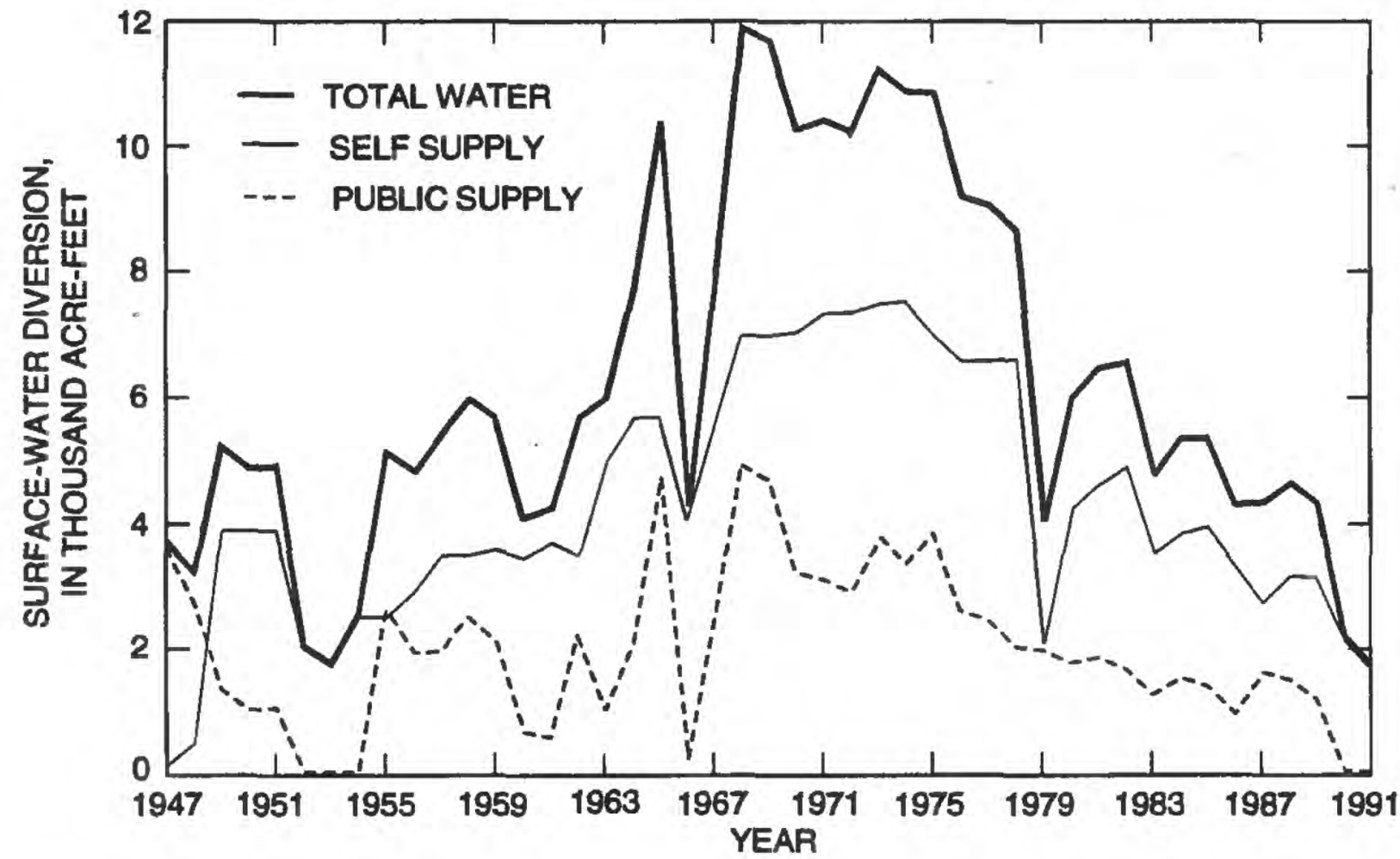

Figure 13. Surface-water diversions in Antelope Valley reported to the California State Water Resources Control Board, Division of Water Rights, 1947-91.

the resulting washes that frequently erode roads in the valley. Some runoff is captured in storm retention reservoirs or withdrawn from streams and from wells adjacent to coarse streambeds. Additional retention facilities could be designed to detain storm runoff to enhance aquifer recharge. Some recharge may be entering the aquifer, but much of it seems to evaporate without providing its maximum potential use.

Preservation of natural recharge areas (such as stream channels and permeable alluvial fans) is an important consideration in the Antelope Valley. Durbin (1978) estimated that 80 percent of total recharge in the valley could be attributed to runoff from the San Gabriel Mountains, primarily from Big Rock and Little Rock Creeks. The upper parts of the alluvial fans associated with these creeks are the primary recharge zones in the valley. Urban encroachment on areas of natural recharge may decrease recharge to the aquifer as pervious areas decrease and natural channels are altered for flood protection.

\section{Imported Surface-Water Supplles}

Imported surface water arrived in the Antelope Valley in 1972, when water was first delivered from the Sacramento-San Joaquin Delta, about $\mathbf{4 0 0} \mathrm{mi}$ to the north, through the California Aqueduct to the
Littlerock Creek Irrigation District and the Antelope Valley-East Kern Water Agency. Imported water supplies peaked in 1981 at about 77,000 acre-ft (table 6). Since then, imported supplies typically have averaged about 37,000 acre$\mathrm{ft} / \mathrm{yr}$, consistently much less than the planned entitlements from the State Water Project. Palmdale Water District first received imported water in 1985. Deliveries of imported water generally have resulted in reduced stress on the ground-water system and have supplemented local water resources for about 20 years. During the 20-year record of imported deliveries, the water delivered to these water agencies seldom has approached the planned entitlement. Part of this difference is due to local water agencies requesting less than their annual entitlement. On the basis of this record and the likelihood of further reductions in exports from the Sacramento-San Joaquin Delta because of the recent endangered species legislation, reliability of water deliveries from the State Water Project is suspect. In addition, part of the imported water received by the Antelope Valley-East Kern Water Agency is delivered to users outside the Antelope Valley. These demands for water from communities outside the valley, such as California City, are expected to increase because of plans for substantial growth. These increasing demands (from outside communities) on the limited supplies imported into the Antelope Valley are equivalent to reducing imported water available for use within the valley.

Discrepancies between entitlements from the State Water Project and actual deliveries (fig. 15) indicate that imported water is not always available when it is needed in the Antelope Valley. A comparison of deliveries projected in 1977 and in 1991 (fig. $15 B$ ) indicates a delay of more than 20 years to reach planned entitlements. This delay probably is due to delays in the planned completion of addittional reservoirs as part of the State Water Project.

Actual deliveries for 1977-92 (California Department of Water Resources, 1991a) typically 
Table 5. Capacities and locations of surface-water reservoirs in the Antelope Valley

[Reservoir capacity, in acre-feet]

\begin{tabular}{|c|c|c|c|c|c|c|}
\hline \multicolumn{3}{|c|}{ Reservoir } & \multicolumn{3}{|c|}{ Location } & \multirow{2}{*}{$\begin{array}{l}\text { Location } \\
\text { No. } \\
\text { (fig. 14) }\end{array}$} \\
\hline Capacity & Name & Owner & $\begin{array}{l}\text { Township/ } \\
\text { range }\end{array}$ & Section & $\begin{array}{l}\text { Latitude/ } \\
\text { longitude }\end{array}$ & \\
\hline \multicolumn{7}{|c|}{ Kern County } \\
\hline 4,375 & Boron Tails Pond 5 & $\begin{array}{l}\text { U.S. Borax and } \\
\text { Chemical Corporation }\end{array}$ & $11 \mathrm{~N} / 8 \mathrm{~W}-$ & 15 & $\begin{array}{l}35^{\circ} 03^{\prime} 18^{\prime \prime \prime} / \\
117^{\circ} 42^{\prime} 36^{\prime \prime}\end{array}$ & 1 \\
\hline 1,480 & Boron Tails Pond & $\begin{array}{l}\text { U.S. Borax and } \\
\text { Chemical Corporation }\end{array}$ & $11 N / 8 W-$ & 15 & $\begin{array}{l}35^{\circ} 02^{\prime} 36^{\prime \prime \prime} / \\
117^{\circ} 43^{\prime} 12^{\prime \prime}\end{array}$ & 2 \\
\hline 2,235 & Boron Tails Pond 6 & $\begin{array}{l}\text { U.S. Borax and } \\
\text { Chemical Corporation }\end{array}$ & $11 \mathrm{~N} / 8 \mathrm{~W}$ - & 21 & $\begin{array}{l}35^{\circ} 03^{\prime} 00^{\prime \prime \prime} \\
117^{\circ} 42^{\prime} 36^{\prime \prime}\end{array}$ & 3 \\
\hline 242 & $\begin{array}{l}\text { Borax Solar } \\
\text { evaporation pond }\end{array}$ & $\begin{array}{l}\text { U.S. Borax and } \\
\text { Chemical Corporation }\end{array}$ & $11 N / 8 W-$ & 21 & $\begin{array}{l}35^{\circ} 02^{\prime} 18^{\prime \prime} / \\
117^{\circ} 44^{\prime} 06^{\prime \prime}\end{array}$ & 4 \\
\hline 17 & $\begin{array}{l}\text { Edwards Air Force } \\
\text { Base recreation } \\
\text { dam }\end{array}$ & $\begin{array}{l}\text { U.S. Air Force, } \\
\text { Edwards Air Force Base }\end{array}$ & 9N/7W- & 24 & $\begin{array}{l}34^{\circ} 56^{\prime} 24^{\prime \prime \prime} \\
117^{\circ} 40^{\prime} 59^{\prime \prime}\end{array}$ & 10 \\
\hline 8,349 & (Subtotal) & & & & & \\
\hline \multicolumn{7}{|c|}{ Los Angeles County } \\
\hline $0\left({ }^{1} 7,507\right)$ & Fairmont & City of Los Angeles & $7 \mathrm{~N} / 15 \mathrm{~W}$ & 12 & $\begin{array}{l}34^{\circ} 41^{\prime} 12^{\prime \prime \prime} / \\
118^{\circ} 25^{\prime} 37^{\prime \prime}\end{array}$ & 5 \\
\hline 4,200 & Lake Palmdale & Palmdale Water District & $5 \mathrm{~N} / 12 \mathrm{~W}$ & 3 & $\begin{array}{l}34^{\circ} 31^{\prime} 36^{\prime \prime \prime} \\
118^{\circ} 06^{\prime} 54^{\prime \prime}\end{array}$ & 6 \\
\hline $900\left({ }^{2} 2,700\right)$ & Littlerock & $\begin{array}{l}\text { Littlerock Creek Irrigation } \\
\text { District and Palmdale } \\
\text { Water District }\end{array}$ & $5 \mathrm{~N} / 11 \mathrm{~W}-$ & 27 & $\begin{array}{l}34^{\circ} 29^{\prime} 06^{\prime \prime \prime} / \\
118^{\circ} 01^{\prime} 19^{\prime \prime}\end{array}$ & 7 \\
\hline 493 & Fairmont No. 2 & City of Los Angeles & $7 \mathrm{~N} / 15 \mathrm{~W}$ & 11 & $\begin{array}{l}34^{\circ} 42^{\prime} 18^{\prime \prime} / \\
118^{\circ} 26^{\prime} 06^{\prime \prime}\end{array}$ & 8 \\
\hline 106 & $\begin{array}{r}\text { Pearblossom } \\
\text { Spill basin }\end{array}$ & $\begin{array}{l}\text { California Department of } \\
\text { Water Resources }\end{array}$ & $5 \mathrm{~N} / 10 \mathrm{~W}-$ & 15 & $\begin{array}{l}34^{\circ} 31^{\prime} 12^{\prime \prime \prime} / \\
117^{\circ} 55^{\prime} 12^{\prime}\end{array}$ & 9 \\
\hline 5,699 & \multicolumn{6}{|c|}{ Subtotal (of the original 15,006 ) } \\
\hline 14,048 & \multicolumn{6}{|c|}{ Total (of the original 23,355 ) } \\
\hline
\end{tabular}

\footnotetext{
${ }^{1}$ Fairmont and Fairmont No. 2 Reservoirs are located along the Los Angeles Aqueduct in the Price Canyon drainage basin. Fairmont Reservoir was completed in 1912 but was taken out of operation in 1982 because of a fault running through the main dam. Fairmont No. 2 replaced Fairmont Reservoir but stores only a fraction of its the original capacity.

${ }^{2}$ Reservoir capacity for Littlerock Reservoir is 2,700 acre-feet which is the design capacity. Actual storage capacity was reduced legislatively by the California Department of Water Resources, Division of Dam Safety, to about 900 acre-feet. Construction plans indicate that completion of a new reservoir in 1994 will increase the useable capacity of Littlerock Reservoir to 3,472 acre-feet.
}

were from 25 to 50 percent of the deliveries projected by the California Department of Water Resources (1977) (fig. 15). The California Department of Water Resources (Paul Dabbs, California Department of Water Resources, written commun., August 1993) analyzed the reliability of imported water supplies for various scenarios that might influence the availability of water for export from the Sacramento-San Joaquin Delta area. On the basis of assumptions made for the various scenarios, results of these analyses indicate a 20 - to 60 -percent likelihood that deliveries will be at or above projected deliveries.

During wet years, even with the present facilities of the State Water Project, more water may be available to water contractors, such as Antelope Valley-East Kern Water Agency, Palmdale Water District, and Littlerock Creek Irrigation District, than is contracted to be delivered. The differences 


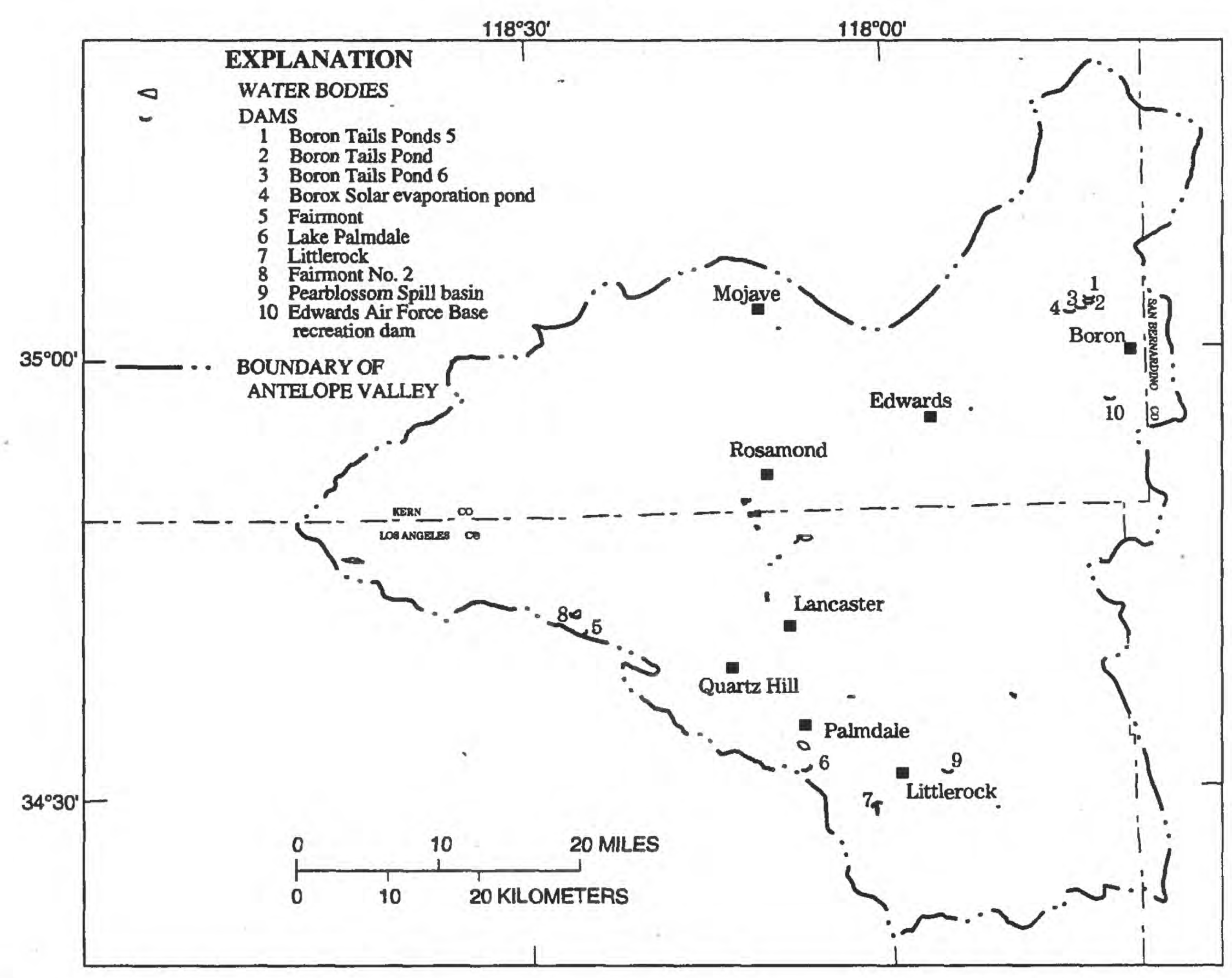

Figure 14. Locations of surface-water reservoirs and other selected water bodies in the Antelope Valley.

between entitlements and deliveries then can be narrowed if more water is requested by these local agencies and placed in storage through artificial recharge.

\section{Reclaimed Wastewater Supply}

Reclaimed wastewater is becoming an important source of water in Antelope Valley. Reclaimed wastewater supplies have increased dramatically as the population and treatment capacities have grown (fig. 16A). In 1985, influents to wastewater treatment facilities from the cities of Lancaster and Palmdale and for Edwards Air Force Base were 6,161 , and 3,394 , and 1,457 acre-ft, respectively, for a combined total of about 11,000 acre- $\mathrm{ft}$, or about 90 percent of total treated sewage $(12,229$ acre-ft; fig. 16B) for all wastewater facilities in the valley. By 1990, the total influent treated by these same three communities had increased to 19,123 acre-ft, which was 92 percent of the total wastewater influent to all Antelope Valley facilities (20,873 acre-ft; table 7). In 1990 , only about 55 percent $(11,483$ acre-ft) of the influent was accounted for by various uses (table 7 ). If all meters on the influents to wastewater facilities were operating properly, the balance probably evaporated from wastewater-treatment ponds or could be accounted for in sewage sludge solids (fig. 16B). In 1990, the Lancaster and Palmdale facilities accounted for 84 percent of the total influent to wastewater-treatment plants in the Antelope Valley. Our data base (fig. $16 B$ ) is limited to data from these two plants for all years except 1985 and 1990, which is why total influent is higher in 1985 and 1990.

In 1990, most reclaimed wastewater was disposed of to land surfaces $(5,445$ acre-ft). Volumes disposed to land surfaces primarily evaporate, but 
Table 6. Entitlements and actual dellveries of water imported to the Antelope Valley from the California Aqueduct

[Entitlement and delivery in acre-feet]

\begin{tabular}{|c|c|c|c|c|c|c|c|c|c|}
\hline \multirow[b]{2}{*}{ Year } & \multicolumn{3}{|c|}{$\begin{array}{c}\text { Antelope Valley- } \\
\text { East Kern Water Agency }\end{array}$} & \multicolumn{2}{|c|}{$\begin{array}{l}\text { Littlerock Creek } \\
\text { Irrigation District }\end{array}$} & \multicolumn{2}{|c|}{$\begin{array}{c}\text { Palmdale } \\
\text { Water District }\end{array}$} & \multirow{2}{*}{$\begin{array}{c}\text { Total }^{1} \\
\text { deliveries } \\
\text { Antelope } \\
\text { Valley } \\
\text { agencies } \\
(\mathrm{h}=\mathrm{b}+\mathrm{e}+\mathrm{g})\end{array}$} & \multirow{2}{*}{$\begin{array}{c}\text { Total } \\
\text { deliveries } \\
\text { Antelope } \\
\text { Valley } \\
\text { (defined in } \\
\text { this study) } \\
(\mathrm{i}=\mathrm{c}+\mathrm{e}+\mathrm{g})\end{array}$} \\
\hline & $\begin{array}{l}\text { Entitle- } \\
\text { ment } \\
\text { (a) }\end{array}$ & $\begin{array}{l}\text { Delivery } \\
\text { (b) }\end{array}$ & $\begin{array}{l}\text { Antelope } \\
\text { Valley } \\
\text { deliveries } \\
\text { (c) }\end{array}$ & $\begin{array}{l}\text { Entitle- } \\
\text { ment } \\
\text { (d) }\end{array}$ & $\begin{array}{l}\text { Delivery } \\
\text { (e) }\end{array}$ & $\begin{array}{l}\text { Entitle- } \\
\text { ment } \\
\text { (f) }\end{array}$ & $\begin{array}{l}\text { Delivery } \\
\text { (g) }\end{array}$ & & \\
\hline 1972 & 20,000 & 53 & 0 & 170 & 338 & 1,620 & $\overline{0}$ & 391 & 338 \\
\hline 1973 & 25,000 & 20 & 0 & 290 & 290 & 2,940 & 0 & 310 & 290 \\
\hline 1974 & 30,000 & 1,259 & 1,259 & 400 & 400 & 4,260 & 0 & 1,659 & 1,659 \\
\hline 1975 & 35,000 & 8,068 & 8,068 & 520 & 520 & 5,580 & 0 & 8,588 & 8,588 \\
\hline 1976 & 44,000 & 27,782 & 27,295 & 640 & 589 & 6,900 & 0 & 28,371 & 27,884 \\
\hline 1977 & 50,000 & 11,202 & 32,147 & 730 & 111 & 8,220 & 0 & 11,313 & 32,258 \\
\hline 1978 & 57,000 & 44,137 & 42,997 & 920 & 208 & 9,340 & 0 & 44,345 & 43,205 \\
\hline 1979 & 63,000 & 60,493 & 58,701 & 1,040 & 133 & 10,260 & 0 & 60,626 & 58,834 \\
\hline 1980 & 69,200 & 72,407 & 66,522 & 1,150 & 191 & 11,180 & 0 & 72,598 & 66,713 \\
\hline 1981 & 75,000 & 79,375 & 75,480 & 1,270 & 1,270 & 11,700 & 0 & 80,645 & 76,750 \\
\hline 1982 & 81,300 & 50,291 & 47,789 & 1,380 & 0 & 12,320 & 0 & 50,291 & 47,789 \\
\hline 1983 & 87,700 & 32,961 & 31,878 & 1,500 & 38 & 12,940 & 0 & 32,999 & 31,916 \\
\hline 1984 & ${ }^{2} 35,000$ & 32,662 & 31.727 & 1.610 & 1 & 13,560 & 0 & 32,663 & 31,728 \\
\hline 1985 & ${ }^{2} 40,000$ & 37,064 & 36,111 & 1,730 & 0 & 14,180 & 1,558 & 38,622 & 37,669 \\
\hline 1986 & ${ }^{2} 42,000$ & 32,449 & 30,946 & 1,840 & 163 & 14,800 & 3,096 & 35,708 & 34,205 \\
\hline 1987 & ${ }^{2} 44,000$ & 34,094 & 31,782 & 1,960 & 1,080 & 15,420 & 5,379 & 40,553 & 38,241 \\
\hline 1988 & ${ }^{2} 46,000$ & 34,079 & 34,828 & 2,070 & 419 & 16,040 & 1,770 & 36,268 & 37,017 \\
\hline 1989 & 125,700 & 45,280 & 40,428 & 2,190 & 971 & 16,660 & 9,009 & 55,260 & 50,408 \\
\hline 1990 & 132,100 & 47,209 & 43,164 & 2,300 & 1,747 & 17,300 & 8,608 & 57,564 & 53,519 \\
\hline 1991 & 138,400 & 22,992 & 4,355 & 2,300 & 858 & 17,300 & ${ }^{1} 6,525$ & 30,375 & 11,738 \\
\hline 1992 & 138,400 & 31,937 & 28,607 & 2,300 & 0 & 17,300 & 4,007 & 35,944 & 32,614 \\
\hline 1993 & 138,400 & & & 2,300 & & 17,300 & & & \\
\hline 2020 & 138,400 & & & 2,300 & & 17,300 & & & \\
\hline 2025 & 138,400 & & & 2,300 & & 17,300 & & & \\
\hline
\end{tabular}

'Sources: California Department of Water Resources (1991a, p. 268 and 280) and written communications from Antelope Valley-East Kern Water Agency, Littlerock Creek Irrigation District, and Palmdale Water District. The entitlements and deliveries shown in this table are from California Department of Water Resources (1991a).

Discrepancies exist between deliveries reported by California Department of Water Resources and the individual agencies for the same years. For example, in 1991, Antelope Valley-East Kern Water Agency indicates their deliveries from the State Water Project totaled 7,263 acre-feet, and Palmdale Water District reported 3,925 acre-feet. The most striking discrepancy is shown in 1977 where (b) 11,202 acre-feet was reported by the California Department of Water Resources and (c) 32,147 acre-feet was reported by Antelope Valley-East Kern Water Agency.

${ }^{2}$ Entitlements for 1984-88 from California Department of Water Resources Bulletin 132-85 (1985) were modified from what had been reported in Bulletin 132-81. The numbers shown in this table are from Bulletin 132-91, which have been unchanged since Bulletin 132-85. Bulletin 132-81 showed 1984, 1985, 1986, 1987, and 1988 entitlements for Antelope Valley-East Kern Water Agency to be 94,$000 ; 100,400 ; 106,700 ; 113,000$; and 119,400 acre-feet, respectively.

also may recharge ground water, evapotranspire through native vegetation, and may compact moisture-deficient soils. Additional monitoring of ground-water levels and quality in the vicinity of this disposal area would be helpful in determining how much ground-water recharge is actually occurring. Wastewater also was used for agricultural irrigation $(3,587$ acre- $\mathrm{ft})$ and wetlands $(2,451$ acre-ft) (table 7; fig. $16 \mathrm{~B}$ ). Nearly 100 percent of the reclaimed wastewater for agricultural irrigation in 1990 was used at the Nebeker Ranch to grow alfalfa and sudan grass. In 1990, 2,451 acre-ft of 

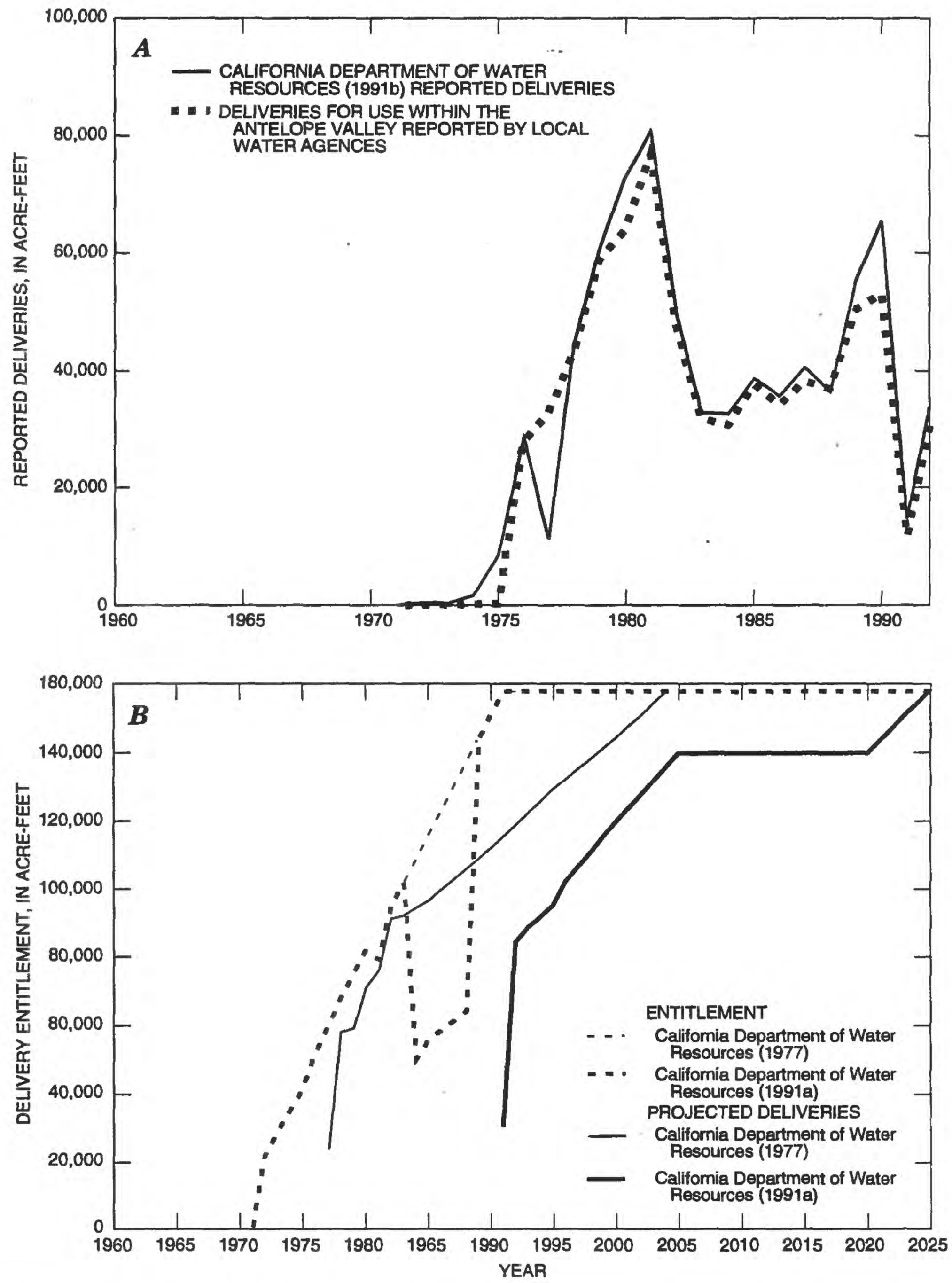

Figure 15. Imported water supplies for the Antelope Valley. A, Reported deliveries. $B$, Entitlements and deliveries projected in 1977 and 1991. 


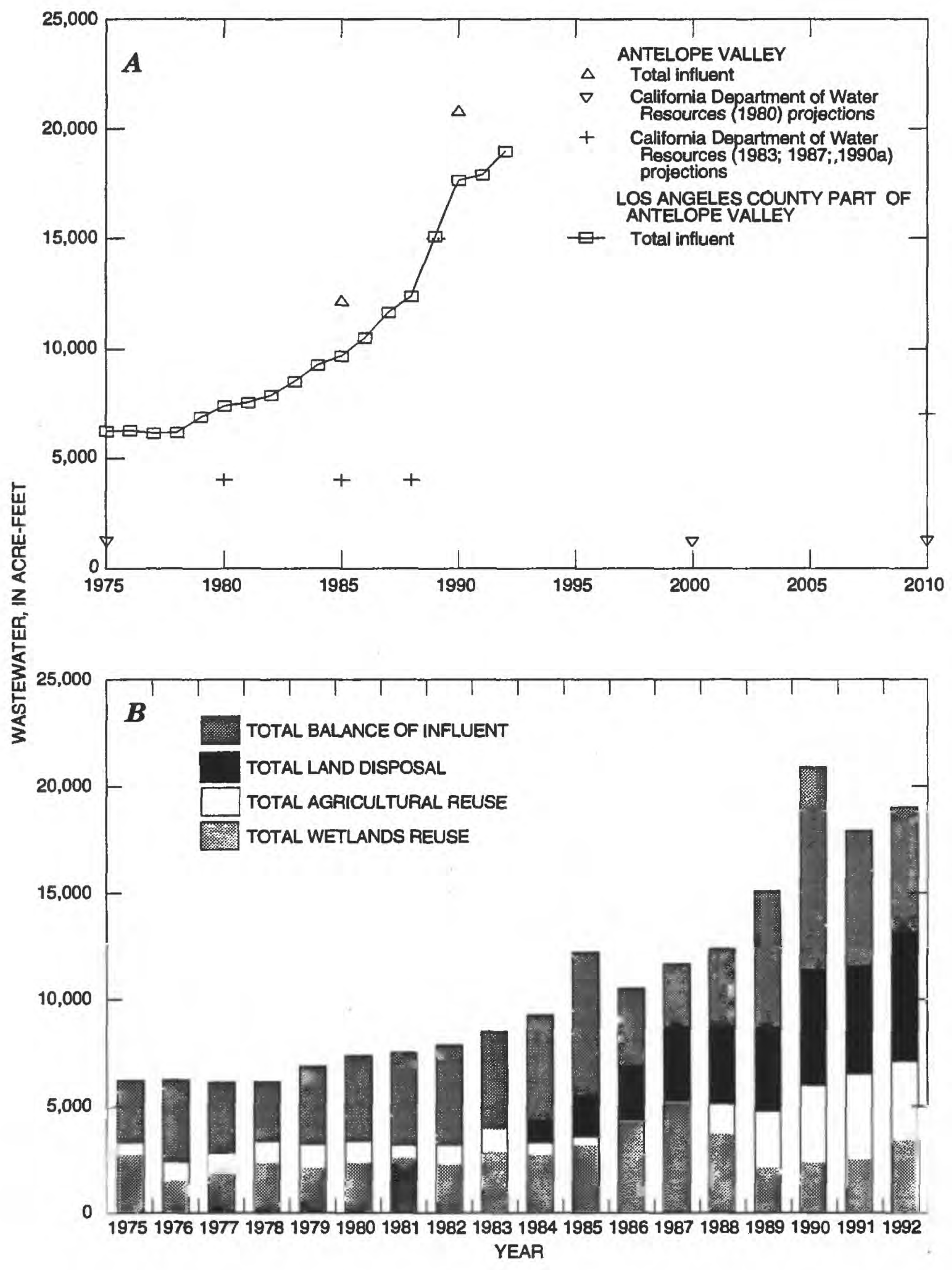

Figure 16. Wastewater $\boldsymbol{A}$ influent and $\boldsymbol{B}$ reuse in the Antelope Valley. (Sources: David Lambert, Los Angeles County Sanitation Districts, written commun., 1993, and U.S. Geological Survey data base, October 15, 1993.) 
Table 7. Wastewater influents and reclaimed wastewater use, 1989-91

[Influent and reclaimed wastewater, in acre-feet per year]

Facility name

Influent

Reclaimed wastewater use

\begin{tabular}{|c|c|c|c|}
\hline $\begin{array}{l}\text { Agricultural } \\
\text { irrigation }\end{array}$ & Wetlands & $\begin{array}{l}\text { Land } \\
\text { disposal }\end{array}$ & $\begin{array}{l}\text { Balance ot } \\
\text { influent }\end{array}$ \\
\hline
\end{tabular}

1989

Edwards Air Force Base Wastewater Treatment Facility . . . .

Rosamond Wastewater Treatment Facility ...........

Mojave Wastewater Treatment Facility ............

Mojave Airport Facility . . . . . . . . . . . . .

Boron Wastewater Treatment Facility .............

Desert Lake Community Services District Wastewater

Treatment Facility ................... 0

Edwards Air Force Base Missile Test Site

Wastewater Treatment Facility...$\ldots \ldots \ldots \ldots \ldots .0$

Edwards Air Force Base North Base Research

Wastewater Treatment Facility ............... 0

Lancaster Wastewater Treatment Facility .......... 8,625

Palmdale Water Reclamation Plant ........... 6,475

Air Force Plant 42 Wastewater Treatment Facility ...... 0

Boron Federal Prison Wastewater Treatment Facility ......

$\begin{array}{ll}0 & 0 \\ 0 & 0 \\ 0 & 0 \\ 0 & 0 \\ 0 & 0\end{array}$

$0 \quad 0$

$0 \begin{array}{lll}0 & 0 \\ 0 & 0\end{array}$

0

0

0

$0 \quad 0$

0

0

2,671

29

0

0

15,100

2,700

2,135

3,965

6,300

\section{0}

Edwards Air Force Base Wastewater Treatment Facility . . . . 1,670

Rosamond Wastewater Treatment Facility . . . . . . . 762

Mojave Wastewater Treatment Facility ........... 381

Mojave Airport Facility . . . . . . . . . . . . . . 99

Boron Wastewater Treatment Facility ............ 90

Desert Lake Community Services District Wastewater

Treatment Facility ................. 86

Edwards Air Force Base Missile Test Site

Wastewater Treatment Facility ............... 45

Edwards Air Force Base North Base Research

Wastewater Treatment Facility .............. 7

Lancaster Wastewater Treatment Facility $\ldots \ldots \ldots \ldots \ldots \ldots .9 . \ldots \ldots$

Palmdale Water Reclamation Plant ........... 8,155

Air Force Plant 42 Wastewater Treatment Facility ........ 8, 213

Boron Federal Prison Wastewater Treatment Facility ..... 67

Total

20,873

0
3,572
15
0
0

0
2,135

0
35

0

0

0

0

0

0

0
0
0
0
0

0

0

0

0

0

3,965

3,819

0

2,481

0

0

0

To91

Edwards Air Force Base Wastewater Treatment Facility . . . .

Rosamond Wastewater Treatment Facility . . . . . . . . .

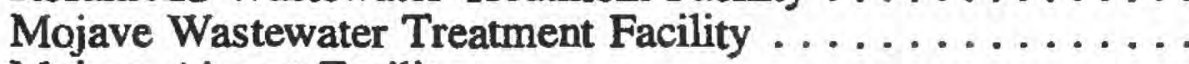

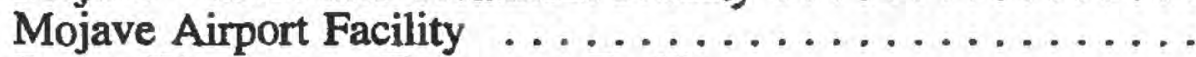

Boron Wastewater Treatment Facility .............

Desert Lake Community Service District Wastewater

Treatment Facility .................... 0

Edwards Air Force Base Missile Test Site

Wastewater Treatment Facility...$\ldots \ldots \ldots \ldots \ldots .0$

3,587

0
0
0
0
0

0

0

0

0

0

(2)

$\begin{array}{lr}0 & 1,670 \\ 0 & 762 \\ 0 & 381 \\ 0 & 99 \\ 0 & 90\end{array}$

6

0

0

86

50

0

0

45

Edwards Air Force Base North Base Research

Wastewater Treatment Facility $\ldots . . \ldots \ldots \ldots \ldots . . .6$

Lancaster Wastewater Treatment Facility . . . . . . . 9,073

Palmdale Water Reclamation Plant ............. 8,827

Air Force Plant 42 Wastewater Treatment Facility .......

Boron Federal Prison Wastewater Treatment Facility .......

827
0

0

0
0

0

0

0

0

0

0

0

0

0
2,451
0
0
0

0
0
5,445
0
0

3,275

2,695

213

67

Total . . . . . . . . . . . . . . . . 17,900

0
3,894
91
0
0

\section{2,451}

5,445

9,390

7
5
5
3
67
790


reclaimed wastewater was used for the wetlands, of which about 2,266 acre- $\mathrm{ft}$ was delivered to Piute Pond (a manmade wetland) and about 185 acre-ft was delivered to a pond at Apollo Park. The reclaimed wastewater that went to Nebeker Ranch and the Piute Pond had undergone secondary treatment processes. The wastewater for the Apollo Park pond underwent a third level of treatment with an alum mixture to remove suspended particles.

\section{Water Demand}

From the 1950 's to the late 1980 's, water demands consistently decreased with decreasing irrigated acreage. Irrigation water demands in 1975 totaled 166,300 acre- $\mathrm{ft}$ in the Antelope Valley, whereas municipal water demands totaled only 26,300 acre-ft (table 2) for a population of about 95,000 (California Department of Water Resources, 1980 , p. 11-16). In 1984, rapid growth in population resulted in a rapid increase in urban water demands. By 1990, the population of the Antelope Valley had increased to 260,400 and continues to grow, but at a decreasing rate compared with the previous 5 years. Most reported urban water demands presently (1994) are met by public suppliers. Unreported self-supplied water also could be contributing to urban water demands and creating a significant stress on local ground-water resources. Public-supplied water accounted for 59 percent $(39,400$ acre- $\mathrm{ft})$ of reported demands (66,707 acre-ft) on ground-water supplies and 64 percent $(82,200$ acre-ft) of total reported water demands $(127,997$ acre-ft) in 1990 (table 8). Of the top 10 water suppliers in the Antelope Valley in 1990, 6 were public water suppliers and 4 were self-supplied agricultural water users (table 8 ).

\section{Public Supplied}

For purposes of this report, public-supplied water use is representative of municipal uses for the Antelope Valley. In 1990, public-supplied water was about 82,200 acre-ft compared with about 81,773 acre-ft in 1989 and 92,082 acre-ft $(76,173$ acre-ft plus the 15,658 acre-ft supplied by Antelope Valley-East Kern Water Agency from self-supplied ground-water pumpage) in 1991 (tables 2 and 8). In 1991, for the first time in local history, selfsupplied water users pumped about 15,658 acre- $\mathrm{ft}$ of ground water and sold it to the Antelope ValleyEast Kern Water Agency to help meet the municipal needs of public water suppliers. This 15,658 acre-ft of ground water was used to replace reductions of imported water caused by the drought. Only since
1986 have total reported public-supplied water demands exceeded self-supplied water demands in the Antelope Valley (tables 18 and 19 at back of report). This trend is attributed to the growth in urban land use and the decrease in irrigated agriculture. The top five public suppliers accounted for 82 percent, 84 percent, and 68 percent of the total public water supplied in 1989,1990 , and 1991 , respectively (table 8 ).

The total estimated population served by public suppliers in 1990 in the Antelope Valley was 212,142 based on data compiled for this study. The total population of the valley in 1990 from U.S. Bureau of the Census records was 260,400 (Vern T. Knoop, California Department of Water Resources, written commun., 1993). The population not served by public suppliers was assumed to be self supplied or supplied by small public water companies for which estimates of the population served were not available. Of the 119 licensed public water suppliers in the Antelope Valley (Gary Silverman, U.S. Environmental Protection Agency, written commun., 1991), the top 10 public suppliers accounted for 86 percent of the total water supplied and 88 percent of the total ground water pumped by public suppliers during 1989-91 (table 8).

Water deliveries from public suppliers are voluntarily reported annually to the California Department of Water Resources by most water agencies statewide. However, in 1990, only 26 of the 119 licensed public water suppliers in the Antelope Valley responded to the State's annual "Water Utility Statistics" survey; some of the largest water suppliers were not represented. Responses to the Water Utility Statistics survey for 1990 indicated that the primary use of public-supplied water in Antelope Valley was for domestic purposes, with relatively small amounts used for industrial purposes. Responses also indicated that public-supplied irrigation water generally was applied to landscaping, golf courses, and other publicly owned areas but not to irrigated crops. Other reported public-supplied water included water unaccounted for as losses between production and delivery. Typically, losses include water lost when flushing fire hydrants and fighting fires, system leaks, and irrigation of some public parks and other facilities where water use is not metered.

Many public water suppliers in the Los Angeles County part of the Antelope Valley report their ground-water pumpage and surface-water diversions to the California State Water Resources Control Board. Several water agencies provided additional water-use records for the Antelope Valley. The 
Table 8. Publlc-supplied and self-supplied water demands in Antelope. Valley by water supplier and source, 1989-91

[Imported water represents water purchased from State Water Project contractors by water suppliers within the study area boundary for the Antelope Valley]

\begin{tabular}{cccccc}
\hline Water supplier & \multicolumn{4}{c}{ Water-supply source, in acre-foot per year } & Total \\
\cline { 2 - 6 } & $\begin{array}{c}\text { Ground } \\
\text { water }\end{array}$ & $\begin{array}{c}\text { Local } \\
\text { surface } \\
\text { water }\end{array}$ & $\begin{array}{c}\text { Imported } \\
\text { water }\end{array}$ & $\begin{array}{c}\text { Reclaimed } \\
\text { wastewater }\end{array}$ & $\begin{array}{c}\text { Tater } \\
\text { deman }\end{array}$ \\
\hline
\end{tabular}

\section{9}

Public supplied:

Los Angeles County Water Works Districts ........

Palmdale Water District ..................

Edwards Air Force Base ..................

Lancaster Wastewater Treatment Facility. .........

Littlerock Creek Irrigation District $\ldots \ldots \ldots \ldots \ldots$

Quartz Hill Water District ...............

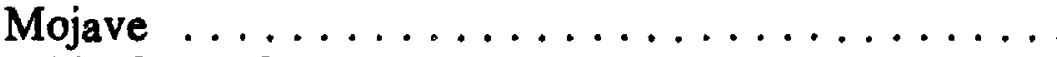

White Fence Farms . . . . . . . . . . . . . . .

.

Palmdale Wastewater Treatment Facility $\ldots \ldots \ldots \ldots$.

All others..............

Total public-supplied water demand

16,619
10,002
5,096
0
1,593
1,661
1,322
368
775
0
5,662

$\overline{43,098}$

7,179

6,914

3,888

2,670

$\mathrm{R}$ and $\mathrm{M}$ Ranch, Inc. . . . . . . . . . . . .

Beery, Ray . . . . . . . . . . . . . . .

Kelly Ranch . . . . . . . . . . . . . . .

Biscaichipy Ranch $\ldots \ldots \ldots \ldots \ldots \ldots \ldots$

Lake, Twyla and Larry $\ldots \ldots \ldots \ldots \ldots \ldots \ldots$

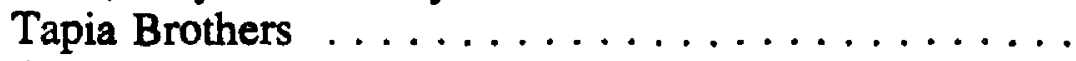

Cameo Ranching Co. . . . . . . . . . . . . . .

Other suppliers

Total self-supplied water demand

Total water supplies
0

0

2,058

0

5,211

$\overline{27,920}$

$\overline{71,018}$

\begin{tabular}{rr}
0 & 17,626 \\
0 & 9,009 \\
0 & 0 \\
0 & 0 \\
1,145 & 971 \\
0 & 1,369 \\
0 & 401 \\
0 & 891 \\
0 & 159 \\
0 & 0 \\
46 & 2,183 \\
\hline 1,191 & 32,609
\end{tabular}

\begin{tabular}{rr}
0 & 34,245 \\
0 & 19,011 \\
0 & 5,096 \\
4,806 & 4,806 \\
0 & 3,709 \\
0 & 3,030 \\
0 & 1,723 \\
0 & 1,259 \\
0 & 934 \\
29 & 29 \\
0 & 7,891 \\
\hline 4,835 & 81,733
\end{tabular}

4,83

7,179

6,914

6,799

2,670

2,189

2,166

2,104

2,058

1,707

1,707

0

6,719

3,127

$\overline{17,796}$

$\overline{3,127}$

$\overline{4,318}$

$\overline{50,405}$

$\overline{4,835} \quad \overline{130,576}$

\section{0}

Public supplied:

Los Angeles County Water Works Districts . . . . . . 14,052

Palmdale Water District . . . . . . . . . . . . . . . . . 10,209

Edwards Air Force Base . . . . . . . . . . . . . $\quad 5,690$

Lancaster Wastewater Treatment Facility .........

Littlerock Creek Irrigation District $\ldots \ldots \ldots \ldots \ldots$.

Quartz Hill Water District .............

Mojave ....................

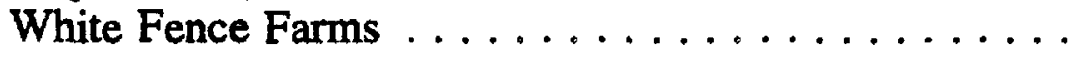

Rosamond Community Services District ........

Palmdale Wastewater Treatment Facility ........

All others

\section{0,917}

8,608

0

r.747

1,950

288

775

498

0

1,933

46

$\overline{36,716}$
34,969

18,817

5,690

6,023

3,273

3,140

1,574

1,563

1,278

15

5,858 
Table 8. Public-supplled and self-supplled water demands in Antelope Valley by water supplier and source, 1989-91-Continued

\begin{tabular}{|c|c|c|c|c|c|}
\hline \multirow[b]{2}{*}{ Water supplier } & \multicolumn{4}{|c|}{ Water-supply source, in acre-foot per year } & \multirow[b]{2}{*}{$\begin{array}{r}\text { Total } \\
\text { water } \\
\text { demand }\end{array}$} \\
\hline & $\begin{array}{c}\text { Ground } \\
\text { water }\end{array}$ & $\begin{array}{c}\text { Local } \\
\text { surface } \\
\text { water }\end{array}$ & $\begin{array}{l}\text { Imported } \\
\text { water }\end{array}$ & $\begin{array}{l}\text { Reclaimed } \\
\text { wastewater }\end{array}$ & \\
\hline \multicolumn{6}{|c|}{ 1990--Continued } \\
\hline 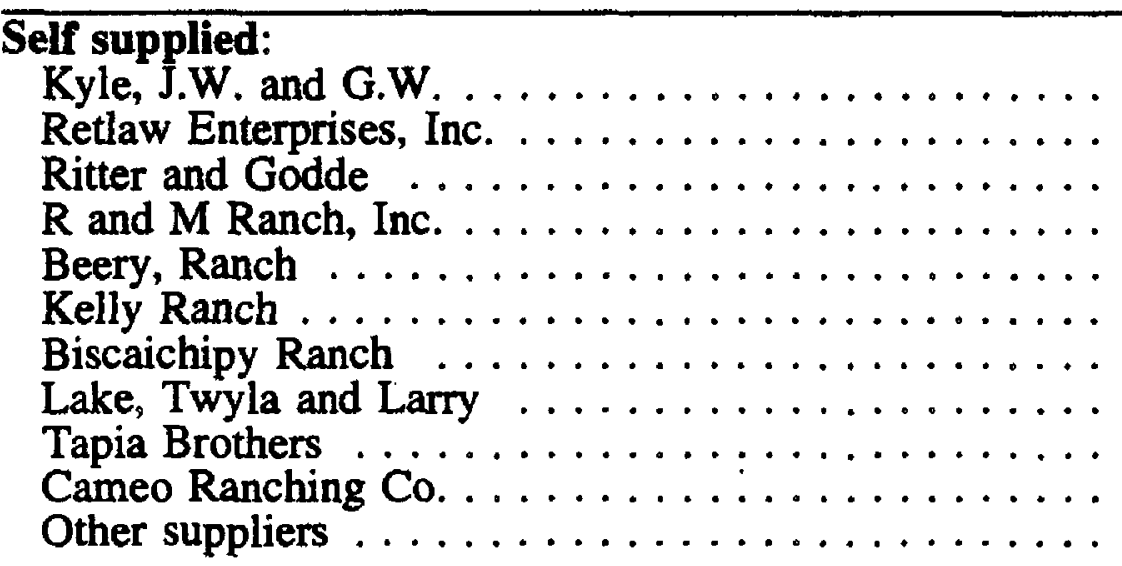 & $\begin{array}{r}6,928 \\
6,904 \\
3,162 \\
2,785 \\
0 \\
0 \\
0 \\
2,052 \\
0 \\
1,365 \\
4,111\end{array}$ & $\begin{array}{r}0 \\
0 \\
0 \\
0 \\
0 \\
0 \\
0 \\
0 \\
0 \\
0 \\
2,119\end{array}$ & $\begin{array}{r}0 \\
0 \\
3,843 \\
0 \\
2,099 \\
1,708 \\
2,437 \\
0 \\
1,294 \\
0 \\
4,990\end{array}$ & $\begin{array}{l}0 \\
0 \\
0 \\
0 \\
0 \\
0 \\
0 \\
0 \\
0 \\
0 \\
0\end{array}$ & $\begin{array}{r}6,928 \\
6,904 \\
7,005 \\
2,785 \\
2,099 \\
2,052 \\
2,437 \\
1,708 \\
1,294 \\
1,365 \\
11,220\end{array}$ \\
\hline Total self-supplied water demand & $\overline{27,307}$ & $\overline{2,119}$ & $\overline{16, \overline{371}}$ & $\overline{0}$ & 45,797 \\
\hline Total water supplies & $\overline{66,707}$ & $\overline{2,165}$ & $\overline{53,087}$ & $\overline{6,038}$ & $\overline{127,997}$ \\
\hline \multicolumn{6}{|c|}{1991} \\
\hline 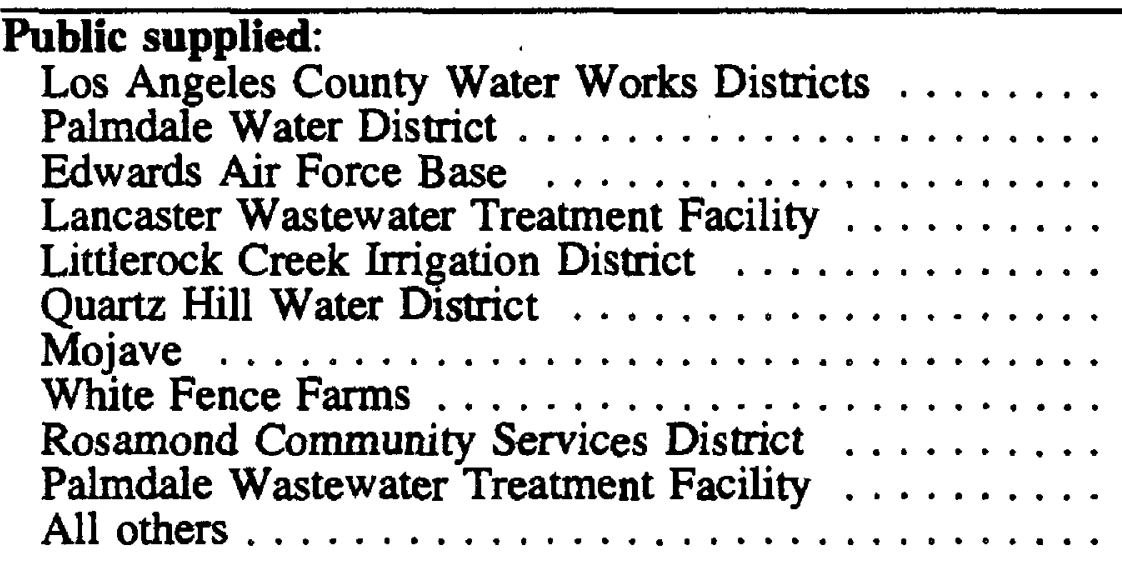 & $\begin{array}{r}17,093 \\
12,720 \\
3,920 \\
0 \\
1,991 \\
1,311 \\
1,214 \\
456 \\
1,235 \\
0 \\
5,269\end{array}$ & $\begin{array}{l}0 \\
0 \\
0 \\
0 \\
0 \\
0 \\
0 \\
0 \\
0 \\
0 \\
36\end{array}$ & $\begin{array}{r}12,940 \\
6,525 \\
0 \\
0 \\
858 \\
1,543 \\
468 \\
482 \\
535 \\
0 \\
16,934\end{array}$ & $\begin{array}{r}0 \\
0 \\
0 \\
6,462 \\
0 \\
0 \\
0 \\
0 \\
0 \\
91 \\
0\end{array}$ & $\begin{array}{r}30,033 \\
19,245 \\
3,920 \\
6,462 \\
2,849 \\
2,854 \\
1,682 \\
938 \\
1,770 \\
91 \\
22,239\end{array}$ \\
\hline Total public-supplied water demand & $\overline{45,208}$ & $\overline{36}$ & $\longdiv { 4 0 , 2 8 5 }$ & $\overline{6,553}$ & $\overline{92,082}$ \\
\hline 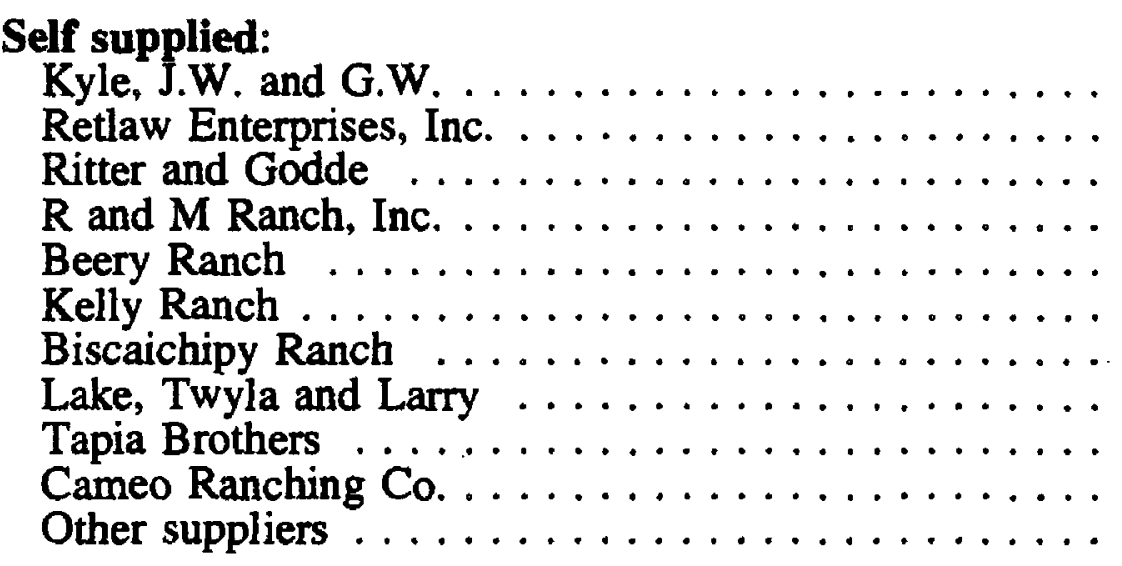 & $\begin{array}{r}7,294 \\
6,914 \\
6,083 \\
2,780 \\
0 \\
0 \\
0 \\
12 \\
0 \\
1,248 \\
6,546\end{array}$ & $\begin{array}{r}0 \\
0 \\
0 \\
0 \\
0 \\
0 \\
0 \\
0 \\
0 \\
0 \\
1,633\end{array}$ & $\begin{array}{r}0 \\
0 \\
0 \\
0 \\
0 \\
0 \\
0 \\
0 \\
0 \\
0 \\
2,769\end{array}$ & $\begin{array}{l}0 \\
0 \\
0 \\
0 \\
0 \\
0 \\
0 \\
0 \\
0 \\
0 \\
0\end{array}$ & $\begin{array}{r}7,294 \\
6,914 \\
6,083 \\
2,780 \\
0 \\
0 \\
0 \\
12 \\
0 \\
1,248 \\
10,948\end{array}$ \\
\hline Total self-supplied water demand & $\sqrt{30,877}$ & $\overline{1,633}$ & $\overline{2,769}$ & $\overline{0}$ & $\overline{35,279}$ \\
\hline Total water supplies & $\sqrt{76,085}$ & $\overline{1,669}$ & $\longdiv { 4 3 , 0 5 4 }$ & $\overline{6,553}$ & $\overline{127,361}$ \\
\hline
\end{tabular}

${ }^{1}$ The volume of imported water use in 1991 is 15,658 acre-feet higher than the volume of imported water shown in table 4; the volume of ground-water use is 15,658 acre-feet lower than the volume of ground-water use shown in table 4. If this water had been used by the owners of these privately owned wells, it would have been considered a self-supplied use. However, in 1991, 15,658 acre-feet of ground water was transferred from self-suppliers to a wholesale water supplier (Antelope Valley-East Kern Water Agency), who in turn sold the water to public suppliers, who delivered the water to their urban water-use customers. This water use is accounted for under imported water for public-supplied users because the ground water was combined with imported water by Antelope Valley-East Kern Water Agency; it was not determined how much ground water and how much imported water went to each public water supplier. Total ground-water pumpage in 1991 sold to Antelope Valley-East Kern Water Agency for deliveries by public suppliers was 91,284 acre-feet; 44,749 acre-feet public supplied; 30,877 acre-feet self supplied; and 15,658 acre-feet self supplied. 
Palmdale Water District maintains computerized data bases of water supplies and deliveries. Annual and seasonal deliveries of public-supplied water in the Antelope Valley have increased dramatically as shown in the data base for Palmdale Water District (fig. 17).

\section{Self Supplled}

Self-supplied water use represents primarily agricultural uses for the Antelope Valley because other reported self-supplied demands are small. Total reported self-supplied water (table 8) was 48,843 acre-ft in $1989,45,797$ acre-ft in 1990, and 35,279 acre-ft in 1991. The top 10 self-supplied water users accounted for 71 percent of the reported total self-supplied water demands and 82 percent of the ground water pumped by self-suppliers in 1989-91. In 1991, for the first time in local history, self-supplied water users pumped about 15,658 acre-ft of ground water and sold it to the Antelope Valley-East Kern Water Agency to help meet the municipal needs of public water suppliers. This 15,658 acre-ft of ground water was used to replace reductions of imported water that were a result of the drought.

The completeness of our self-supplied data base was checked by comparing 1987 and 1992 irrigated acreages with site-specific locations for water delivery identified by the Antelope Valley-East Kern Water Agency. This comparison indicated that most of the land irrigated in the Kern County area probably used water received from the Antelope Valley-East Kern Water Agency, so selfsupplied water use in Kern County might have been minimal.

Our estimate of the annual total water demand for self-supplied domestic water users from all water sources was about 20,000 acre-ft for 1990 . This estimate was based on a unit-use coefficient of 400 gal per capita per day, similar to the unit-use coefficient for local public-supplied per capita use rates reported to the California Department of Water Resources 1990 Urban Water Status Survey. The population estimate for self-supplied domestic water users was 48,258 for 1990 . This population estimate was determined using the difference between population from the 1990 census (California Department of Water Resources, 1993b) for Antelope Valley and the population served by public water suppliers (for which estimates of the population served were available). Part of this water demand probably was accounted for in the reports of water-rights licensees for surface-water and ground-water pumpage for the Los Angeles County part of the study area as reported to the State Water Resources Control Board. To avoid double accounting, this estimate of domestic selfsupplied water demand was not added to the total reported in table 8 , which could mean that a small amount of self-supplied water use may not be accounted for in our data base. If the per capita use rate for self-supplied domestic water users is actually about $200 \mathrm{gal} / \mathrm{d}$ or even the 55 to $75 \mathrm{gal} / \mathrm{d}$ used by the California State Water Resources Control Board (1977, p. 22) in establishing water rights, the unaccounted for water use would be even less. A complete survey of all active wells and mandatory reporting of all ground-water pumpage would improve estimates of self-supplied water use.

Estimates of self-supplied industrial water use can be made using "unit-use coefficients" for the number of employees reported by local Boards of Trade or Chambers of Commerce for the area within each Standard Industrial Classification code grouping. However, because of potential inaccuracies associated with the "unit-use coefficient" method for estimating industrial water-use, only reported data were used. Unreported use was assumed to be minimal. Some self-supplied wateruse information for the Antelope Valley came from industries that responded to questionnaires sent out as part of a statewide industrial survey done in cooperation with the California Department of Water Resources in 1992. Additional information on self-supplied industrial water use came from industrial well owners in the Los Angeles County part of the study area who report their pumpage to the California State Water Resources Control Board as part of their ground-water extraction ordinance.

Many well owners in the Los Angeles County part of the Antelope Valley, who report their pumpage to the California State Water Resources Control Board as part of the ground-water extraction ordinance, are self-supplied irrigation water users. Irrigation was the most frequently cited water use by those who reported self-supplied pumpage in 1990. Land-use information was used to check the completeness of the reported irrigation information.

Total agricultural water use in the Antelope Valley has been estimated using the "consumptiveuse method" on the basis of irrigated acreage, evapotranspiration of applied water, and irrigation 

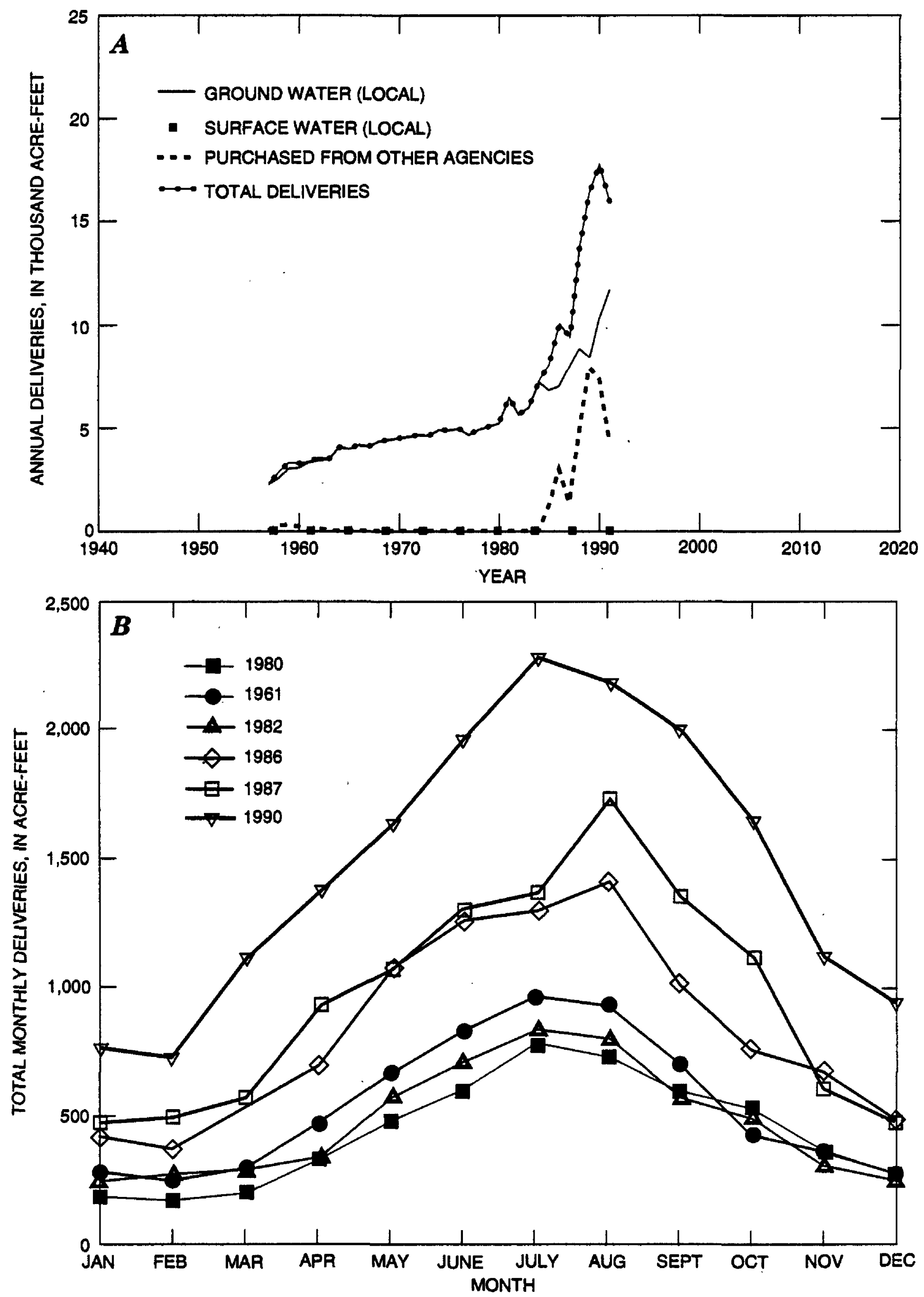

Figure 17. Annual withdrawals by $\mathbf{A}$, source and $\boldsymbol{B}$, seasonal water deliveries, by month, to meet demands for the Palmdale Water District. 
Table 9. Irrigation water use and Irrigated acreage in the Antelope Valley, 1989

[Source: Verne Knoop, California Department of Water Resources (written commun., 1991). Units: applied water and evapotranspiration of applied water are in acre-feet per year; unit evapotranspiration and unit applied water are in acre-feet per acre; irrigation efficiencies are decimal fractions used to estimate applied water following the formula (acres $x$ unit) evapotranspiration of applied water divided by irrigation efficiency. acre-ft/acre, acre-feet per acre; acre-ft, acrefeet]

\begin{tabular}{|c|c|c|c|c|c|c|}
\hline Crop & $\begin{array}{l}\text { Irrigated } \\
\text { acreage }\end{array}$ & $\begin{array}{c}\text { Unit } \\
\text { evapotrans- } \\
\text { piration of } \\
\text { applied water } \\
\text { (acre-ft/acre) }\end{array}$ & $\begin{array}{c}\text { Evapotrans- } \\
\text { piration } \\
\text { of applied } \\
\text { water } \\
\text { (acre-ft) }\end{array}$ & $\begin{array}{c}\text { Unit } \\
\text { applied } \\
\text { water } \\
\text { (acre-ft/acre) }\end{array}$ & $\begin{array}{l}\text { Irrigation } \\
\text { efficiency }\end{array}$ & $\begin{array}{c}\text { Applied } \\
\text { water } \\
\text { (acre-ft) }\end{array}$ \\
\hline Alfalfa & 9,050 & 4.3 & 38,915 & 5.5 & 0.78 & 49,891 \\
\hline Pasture & 660 & 4.3 & 2,838 & 5.5 & .78 & 3,638 \\
\hline Grain & 420 & .2 & 84 & 1.0 & .20 & 420 \\
\hline Corn & 50 & 1.7 & 85 & 2.7 & .62 & 137 \\
\hline Other field & 150 & 2.2 & 330 & 3.5 & .62 & 532 \\
\hline Other truck & 3,040 & 1.5 & 4,560 & 2.5 & .61 & 7,475 \\
\hline Deciduous & 1,970 & 2.6 & 5,122 & 3.8 & .68 & 7,532 \\
\hline Vineyard & 30 & 2.5 & 75 & 3.3 & .75 & 100 \\
\hline Total & $\overline{15,370}$ & & $\overline{52,009}$ & & & $\overline{69,725}$ \\
\hline
\end{tabular}

efficiency for several years (table 2). An example of this method is provided to show how an estimate was made for 1989 irrigation water use in Antelope Valley (table 9). The preliminary estimate of 1989 irrigation water use shown (table 9) indicates 52,000 acre- $\mathrm{ft}$ of water would have been demanded by the 15,370 acres of crops estimated to have been grown in the valley. The final estimate of 49,000 acre-ft of agricultural demand (table 2) for 1989 means that some changes were made in the data presented in table 9. This variation in estimates can provide an indication of the range in reliability that we might expect from the consumptive-use estimate. For comparison, our data base for all self-supplied water users in the Antelope Valley in 1989 (mainly agricultural irrigation water users) has a reported 48,843 acre-ft of water used (table 3 ). This comparison of estimated uses with reported uses indicates that our data base probably accounts for most of the irrigation water use that occurred in 1989. However, the only way to be certain that all water use is accounted for each year would be to establish routine data collection, monitoring, and analysis. There could be substantial error when comparing estimates based on "consumptive" or "net" water use with a combination of reported uses from various sources that represents "gross" water use, or total withdrawals. This error could be as large as 25 percent, the difference between the applied water estimate, 69,725 acre-ft, and the evapotranspiration of applied water, 52,009 acre- $\mathrm{ft}$ (table 9).
Water used for mining is commonly self supplied. Some local mining companies in the Antelope Valley voluntarily provided data on their water use for this study. However, the volumes they reported are insignificant when compared with irrigation water use in the area, accounting for only about 2 percent of the total self-supplied water use. Total annual water use for mining reported in 1990 for the Antelope Valley was 1,150 acre-ft, which includes both public-supplied and self-supplied water. For 1990, the largest reported user of water for mining was the U.S. Borax and Chemical Corporation at 178 acre-ft (146.5 acre-ft of ground water and 31.4 acre-ft of imported surface water purchased from Antelope Valley-East Kem Water Agency). For all uses (domestic, commercial, industrial, and mining) in 1990, the U.S. Borax and Chemical Corporation reported a total use of 1,682 acre-ft of ground water and 865 acre-ft of imported surface water from Antelope Valley-East Kern Water Agency (table 18 at back of report).

\section{Water-Demand Forecasts}

The difficulty of making valid predictions, projections, or forecasts is readily evident. For example, the unpredictable nature of weather often is apparent in our daily lives, especially when forecasts are made for more than a few days into the future. Water managers, however, need to anticipate water needs for years and even decades 


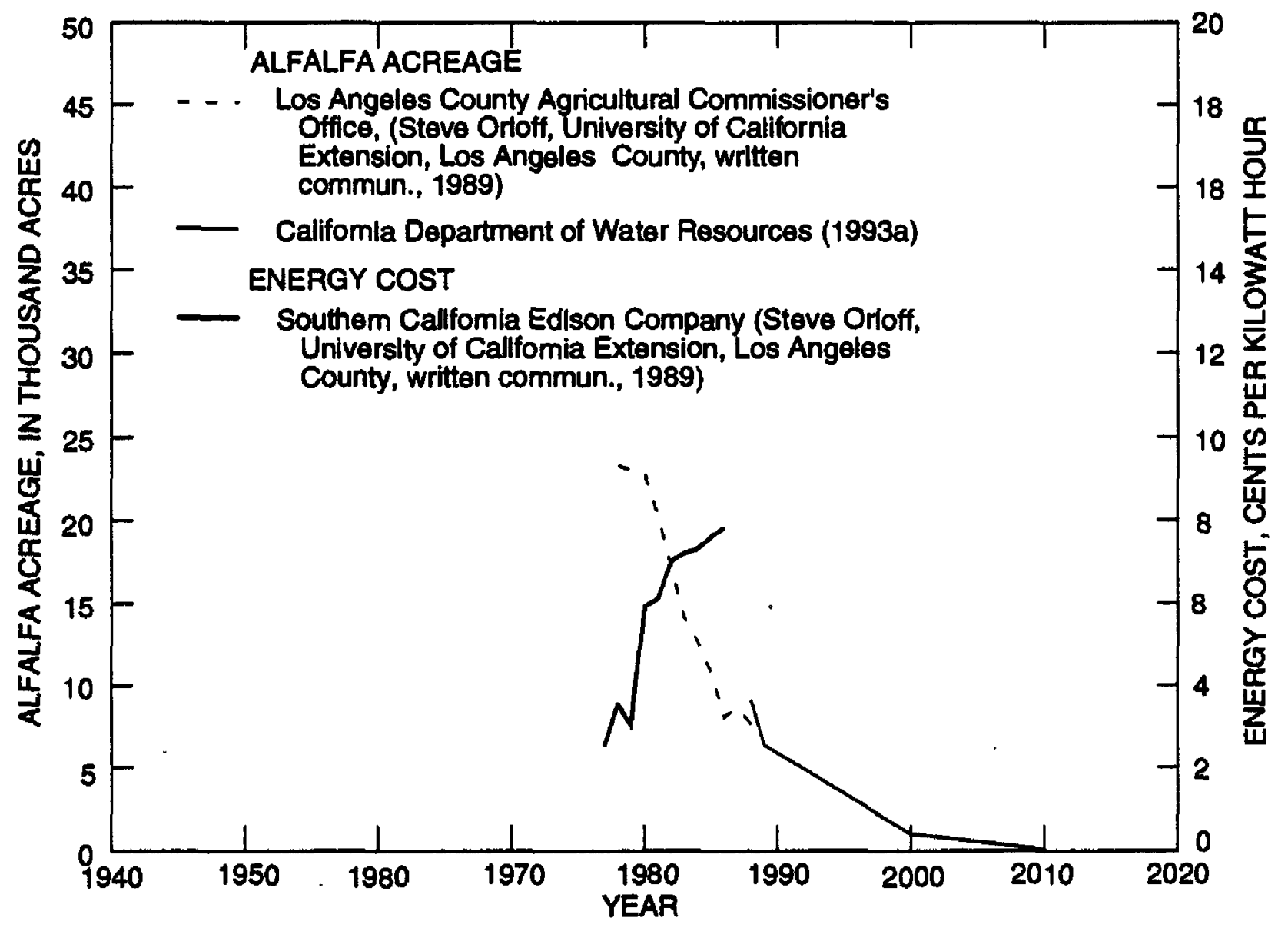

Figure 18. Historical and predicted alfalfa acreages and historical electrical costs in the Antelope Valley.

into the future. To help plan for these future needs, they look to various tools and approaches to provide some information. An essential component of water-resources planning is the water-use forecast, an estimate of the amount of water that will be used at future points in time. Although water-use forecasts help structure debate over water-policy issues, they generally are inaccurate (U.S. Geological Survey, 1990, p. 7) because underlying factors that determine future water use are likely to change in unpredictable ways. Despite the likelihood that long-term projections will prove inaccurate, forecasts still are integral to the process of waterresource planning.

Methods of water-demand forecasting commonly used in the study area, as well as in other areas within and outside of the State of California, are reviewed in this report. The first water-demand forecast specifically for the Antelope Valley was made by the California Department of Water Resources (1980, p. 11) on the basis of information available in 1975 . The forecasters recognized that many factors probably would make the accuracy of their estimate short lived. In 1975, several projections for irrigated land use for the Antelope Valley were made by various agencies with each projection being significantly different. Because of the uncertainty in the projection of irrigated land use, the 1975 acreage was kept constant through the year 2020. Agricultural land use decreased steadily from the mid-1950's to the early 1970's as a result of urban encroachment, increasing water costs, and rising land values (California Department of Water Resources, 1980, p. 11). By 1972, agricultural land use had increased slightly as a result of increasing crop prices and deliveries of imported water for agricultural users by the Antelope Valley-East Kern Water Agency. However, the availability of imported water for agricultural users was expected to decrease sharply in 1983 [which it did (table 6)] when renewal of the State Water Project energy contracts would increase the cost of the imported water. The California Department of Water Resources (1980, p. 14) projected a constant agricultural water demand of about 166,250 acre- $\mathrm{ft} / \mathrm{yr}$ (table 2).

Instead of remaining constant, agricultural water demand has decreased to about 35,279 acre- $\mathrm{ft}$ as of 1991 (tables 2 and 8). Because of the decreasing trend in irrigated acreage during the past few years, a simple projection approach can indicate future agricultural water demands on the basis of historical information of increasing electrical costs and decreasing alfalfa acreages (fig. 18). Unless changes in the value of alfalfa or the cost of electricity occur, this method indicates that less ground water will be pumped for alfalfa irrigation. Reclaimed wastewater, however, may continue to be 

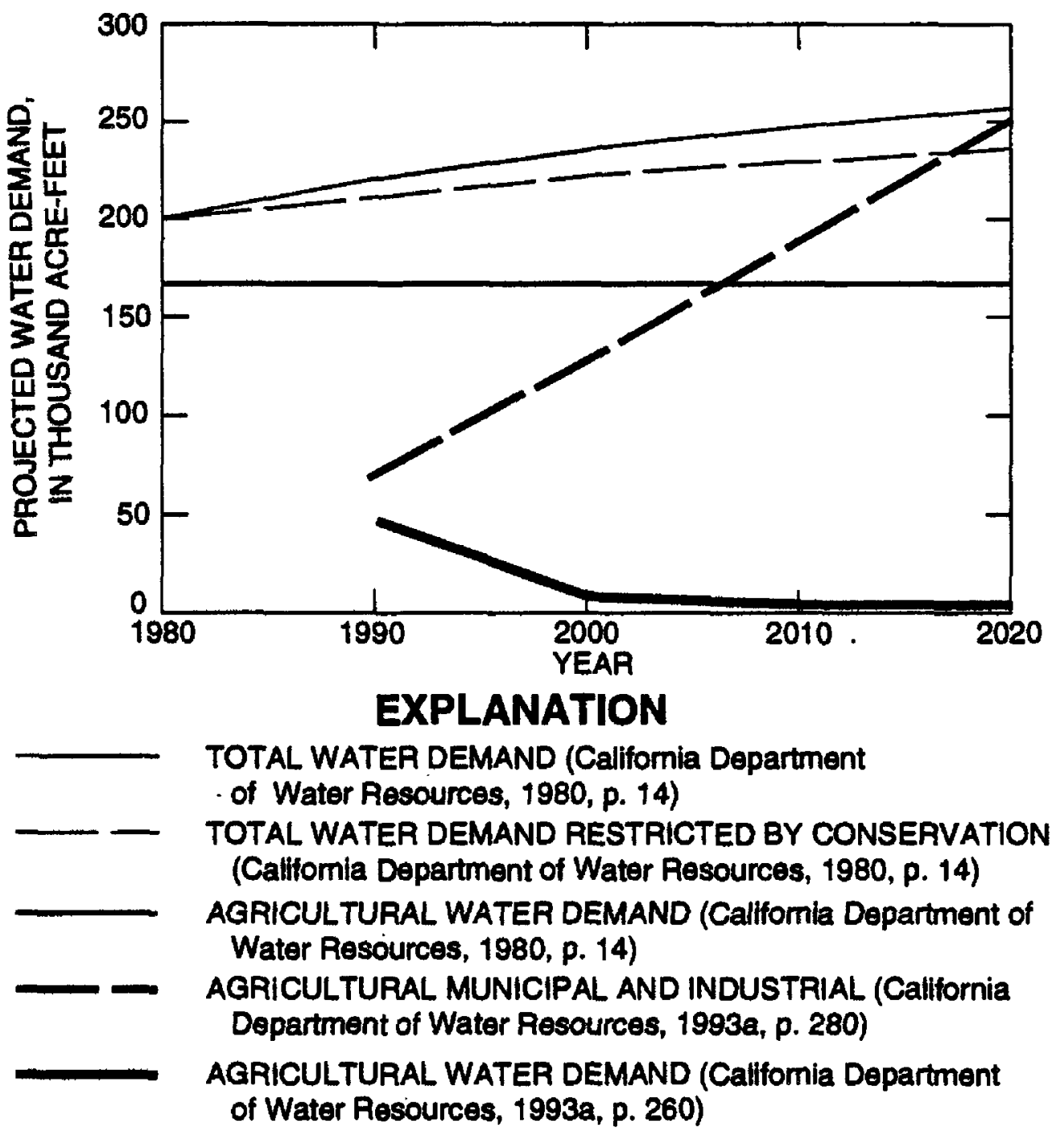

Figure 19. Water-demand projections for the Antelope Valley made in 1980 and 1990 to the year 2020. Total water demands projected in 1980 by the Dapartment of Water Resources included agricultural, municipal, and industrial demands.

a source of water supply for alfalfa in the study area and probably will increase in the future.

Statewide forecasts, or projections, for water supplies and water demands have been made for sources of water supply and types of water use by the California Department of Water Resources since 1966. These forecasts were updated in 1970, 1974, 1983,1987 , and 1993 at a statewide level

(California Department of Water Resources, 1983, p. $19 ; 1987$, p. 18,1993 , v. 2, p. 260). Earlier forecasts (1966, 1970, and 1974) as well as the most recent forecast (1993) were made to the year 2020. The 1983 and 1987 updates were extended only to the year 2010 because of increased concern about the uncertain future of the agricultural economy and the population growth. Since 1983, these forecasts have been made for regions termed "planning subareas." The Antelope Valley is considered a "planning subarea." Basinwide forecasts made in 1980 and 1993 are available for this study area (fig. 19). The most recent projections for urban water demand for the Antelope Valley are 122,000 to 126,000 acre-ft for 2000 ;
180,000 to 186,000 acre-ft for 2010 ; and 243,000 to 250,000 acre-ft for 2020 (California Department of Water Resources, 1993a, p. 260).

According to Cameron and others (1993, p. 1), the methods used by the California Department of Water Resources to make basinwide forecasts for water demand have been "based entirely upon non-stochastic point estimates of base unit use for each category of water use, fractional reduction in unit use in that category, and the population affected by each conservation measure." Deficiencies in this method have been recognized that can create misleading implications of a much greater degree of accuracy than the available information allows (Cameron and others, 1993, p. 1). These deficiencies include the lack of validationverification procedures and confidence limits. Beginning with the 1998 forecasts, a simulation approach is planned to "succinctly convey the consequences of the stochastic nature of all of the ingredients." The many vagaries of demographics, weather, technology, and economics make forecasts so uncertain that this uncertainty needs to be understood. Further, there are wide bands of error on each side of any forecast, and these bands increase as forecasts reach farther into the future.

Water demands are expected to increase with continued urban development in the valley. Forecasting, or predicting future water demands, is of interest to those who are responsible for ensuring that sufficient water is available for the area. Forecasts can be based on projections of population growth, increases in numbers of water meters being installed, changes in acreages of land use, and through the use of many other socioeconomic variables.

\section{Forecasts by Other Agencies}

Planning forecasts for Los Angeles County Water Works Districts in the Antelope Valley were identified during our study (Henry Roedeger, Los Angeles County Department of Public Works. Lancaster, written commun., 1992). These forecasts used growth projections of 5 to 6 percent per year (obtained from planning departments of local 
communities) and annual increases.in the number of meters in each of their districts to estimate the total number of meters projected to be in use by 1998 . This method of forecasting is less complex than the methods used by the Califormia Department of Water Resources and the Metropolitan Water District of Southern California, but doesn't really estimate water demand. These predictions also are for a relatively short period-about 5

years-compared with projections by the California Department of Water Resources, which are for about 30 or 40 years.

Water-demand forecasts for Littlerock Creek Irrigation District were included in a report by Suzuki (1987, p. 4-14a and 4-14b). These forecasts indicated water demand was expected to follow population growth (about 4 percent per year). By 2010 , population was projected to be about 5,000 and water demand was forecasted to be about 2,000 acre-ft/yr (1.6 acre-ft/yr for a family of four), with water demand doubling between 1990 and 2010 . By the year 2040, population was forecasted to be about 15,000 and water demand about 4,500 acre$\mathrm{ft} / \mathrm{yr}$ (1.2 acre- $\mathrm{ft} / \mathrm{yr}$ for a family of four), indicating a decreased rate of use per person. No explanation was provided to describe the method used or the reasons behind these expectations for water-demand reductions for a family of four, but it may be assumed to be a result of conservation and reductions of irrigated orchard acreage within the district.

\section{MAiN System Forecasts}

The most sophisticated method identified in this study for forecasting urban water demands is the MAIN system. The IWR_MAIN Water Use Forecasting System is a computerized planning tool for estimating present and future water demands (Davis and others, 1991, p. I-1). The system is a collection of data intensive, econometric regression models that can be used to make detailed forecasts of water demand. The IWR_MAIN system was developed by Planning and Management Consultants, Ltd., under contract to the U.S. Army Corps of Engineers and has been modified specifically for the Metropolitan Water District of Southern California (MWD_MAIN). MAIN is an acronym for Municipal And Industrial Needs; IWR is an acronym for the Institute of Water Resources of the U.S. Army Corps of Engineers (located at Ft. Belvoir, Virginia), and MWD is for the Metropolitan Water District of Southern California. These systems are intended for use in estimating and forecasting public-supplied water demands for municipal and industrial needs but not for irrigation or self-supplied municipal and industrial needs.

One of the most challenging problems to users of this system occurs when trying to convert available census data into the data required by the MAIN model (Thompson and others, 1993, p. 425). Many assumptions and adjustments can be required that may be highly speculative or inaccurate. The MAIN model can be used with varying amounts of input data for a base year (1980 in this case), but has a minimum requirement of four variables: population, employment (by Standard Industrial Code-SIC), income, and total number of housing units for each of two housing categories (single family and multifamily; table 10). Forecasts and projections can be made with a relatively small amount of information using the "internal" growth models contained within the MAIN systems (table 11). A coefficient library, internal to the MWD_MAIN system, contains default information that can be combined with baseline information to make forecasts. The advantages of using the defaults are that the system requires a relatively small amount of information, scenarios can be changed, and the user can make "what if" comparisons with relative ease. The primary disadvantage of relying on these default coefficients is that the results may not be an accurate representation of the modeled area.

Projections can be modified to produce an "external forecast" using data outside the MWD_MAIN system, which is provided by the user. This method can produce greater accuracy for a given area or water district. The primary advantage of external forecasting is that customized study-area forecasts can be developed that are potentially very accurate when good data are available. The MAIN systems also are valuable for their use in analyzing various future scenarios. The primary disadvantages of external forecasting are (1) the system is data intensive and (2) good data can be expensive and time consuming to obtain.

The MAIN system of models, though complex, provides the user with a wide variety of capabilities. Data-manipulation capabilities are numerous, with many options for disaggregating or aggregating data into sectors of water use. Water-pricing, income, and population data are taken into account, as well as seasonal climatic changes. Once a basic model is developed, the MAIN system can simulate 
Table 10. Data requirements for the MWD_MAIN base year 1980

[Explanation of Symbols: CCI, Composite Construction Index; SIC, Standard Industrial Code; \$/Kgal, dollar per thousand gallons; gal/d, gallon per day; gal/d/unit, gallon per day per unit; --, no data available]

Sources of data:

Population:

Lancaster and Palmdale: City of Lancaster (1993); Southern California Association of Governments (1993).

Antelope Valley: California Department of Water Resources (1980, 1993b).

Income:

Lancaster and Palmdale: Southern California Association of Governments (1993).

Antelope Valley: Alfred Gobar and Associates (1993). All income estimates for 2000 and 2010 derived from a 6-percent increase every 10 years based on Planning and Management Consultants, Ltd., income projections for Los Angeles County. All income values reported in 1980 dollars.

Employment:

Lancaster: U.S. Department of Commerce (1980).

Palmdale: Pete Eskis, California Employment Development Department (written commun., 1993).

Lancaster and Palmdale: Southern California Association of Governments (1993).

Antelope Valley: Sum of employment totals for Lancaster, Palmdale, and Kern County for 1975; sum of Los Angeles and Kern County employment totals from Southern California Association of Governments (1993) and Kern County Council of Governments (1990).

Temperature and Rainfall: National Oceanic and Atmospheric Administration (1991).

Composite Construction Index: Eva Opitz, Planning and Management Consultants, Ltd. (oral commun., 1993).

Housing, total number of housing units:

Lancaster and Palmdale (single family and multifamily): Southern California Association of Governments (1993).

Antelope Valley: Alfred Gobar and Associates (1993).

Distribution of housing throughout the value ranges for single-family and multifamily housing: U.S. Department of Commerce (1980).

Number of persons per household:

Lancaster and Palmdale: U.S. Department of Commerce (1970, 1980, 1990).

Antelope Valley: Alfred Gobar and Associates (1993).

Water rates:

Lancaster and Antelope Valley: Ramon Gonzales, Los Angeles County Department of Public Works (written commun., 1993).

Palmdale and Antelope Valley: Tammy Lucas, Palmdale Water District (oral commun., 1993).

\begin{tabular}{|c|c|c|c|c|c|c|c|}
\hline Data requirements & 1975 & 1980 & 1984 & 1987 & 1990 & 2000 & 2010 \\
\hline \multicolumn{8}{|c|}{ LANCASTER } \\
\hline \multirow{2}{*}{\multicolumn{8}{|c|}{ Required data }} \\
\hline & & & & & & & Municipal \\
\hline Base year & -- & 1980 & -- & -- & -- & -- & -. \\
\hline Total population & -. & 48,103 & 53,827 & 68,063 & 97,291 & 152,279 & 212,140 \\
\hline Median income & .- & 24,499 & 25,013 & 20,943 & 25,046 & 26,549 & 28,142 \\
\hline Total employment & 15,516 & 14,808 & 15,195 & 23,240 & 42,039 & 63,217 & 83,320 \\
\hline $\mathrm{CCl}$ or alternate $\mathrm{CCl}$ & -- & 143.3 & .. & -- & -- & -- & -- \\
\hline Rainfall, in inches & -- & 5.7 & -- & -- & -- & -- & -- \\
\hline Maximum summer temperature & _- & 107 & -- & -- & -- & -- & -- \\
\hline Cooling degree days & -- & 1,635 & -- & -- & -- & -- & -- \\
\hline \multicolumn{8}{|l|}{ Residential } \\
\hline Multifamily, housing by value range & -- & $\left({ }^{1}\right)$ & -- & -- & -- & _- & -- \\
\hline Multifamily, persons per unit & -. & 4.1 & .- & .- & -- & .- & -- \\
\hline Multifamily, winter rate $(\$ / \mathrm{Kgal})$ & -- & .44 & -- & -- & -- & -- & -- \\
\hline Multifamily, summer rate (\$/Kgal) & -- & .44 & _. & .- & .- & .. & \\
\hline Single family, housing by range & -- & $\left({ }^{1}\right)$ & -- & -- & -- & -- & -- \\
\hline Single family, persons per unit & -- & 2.4 & -- & -- & -- & -- & -- \\
\hline Single family, winter rate ( $\$ / \mathrm{Kgal}$ ) & -- & .56 & -- & -- & -- & -- & -- \\
\hline Single family, summer rate $(\$ / \mathrm{Kgal})$ & -- & .56 & _- & -- & -- & -- & -- \\
\hline
\end{tabular}

See footnotes at end of table. 
Table 10. Data requirements for the MWD_MAIN base year 1980-Continued

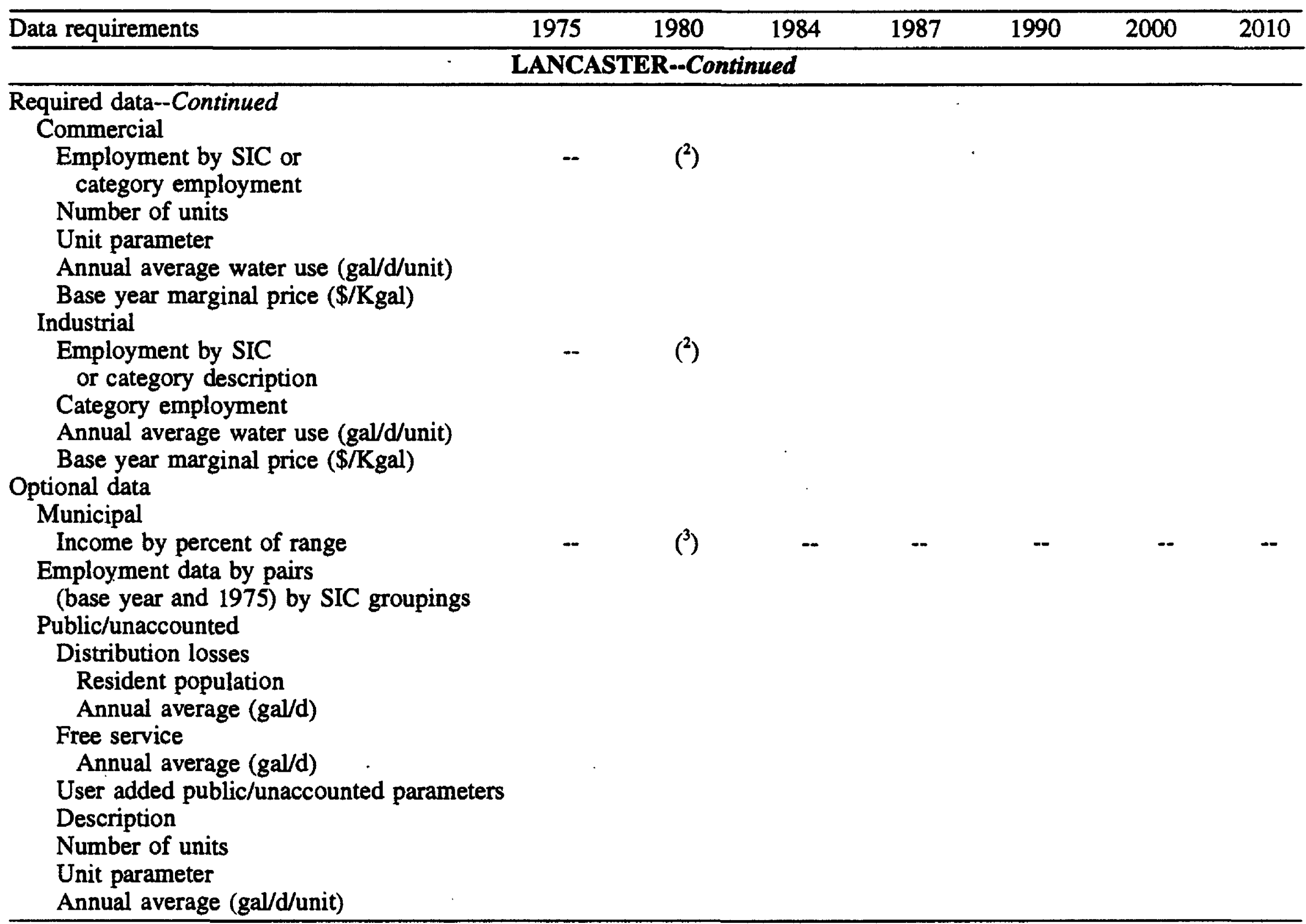

\section{PALMDALE}

Required data

Municipal

Base year

Total population

Median income

Total employment

CCI or alternate CCI

Rainfall, in inches

Maximum summer temperature

Cooling degree days

Residential

Multifamily, housing by value range

Multifamily, persons per unit

Multifamily, winter rate (\$/Kgal)

Multifamily, summer rate (\$/Kgal)

Single family, housing by range

Single family, persons per unit

Single family, winter rate $(\$ / \mathrm{Kgal})$

Single family, summer rate $(\$ / \mathrm{Kgal})$

\begin{tabular}{|c|c|c|c|c|c|c|}
\hline -- & 1980 & - & - & - & -- & 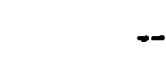 \\
\hline -- & 12,287 & 17,711 & 33,103 & 68,842 & 161,200 & 226,425 \\
\hline -- & 21,838 & 20,363 & 18,398 & 27,386 & 29,029 & 30,771 \\
\hline 5,358 & 7,081 & 6,400 & 10,000 & 16,075 & 34,104 & 51,621 \\
\hline-- & 143.3 & -- & -- & -- & -- & -- \\
\hline-- & 5.8 & - & -- & -- & -- & -- \\
\hline -- & 107 & .. & -- & -- & -- & $\cdots$ \\
\hline -- & 1,635 & -. & -- & -- & -- & -- \\
\hline-- & (l) & -- & -- & -- & -- & -- \\
\hline-- & 2.03 & -- & -- & -- & - & -- \\
\hline$\cdots$ & .53 & -- & -- & -- & -- & - \\
\hline-- & .53 & - & -- & -- & -- & - \\
\hline-- & $\left({ }^{1}\right)$ & -- & - & - & -- & 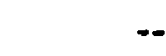 \\
\hline-- & 2.44 & -- & -- & -- & -- & -- \\
\hline-- & .53 & - & - & - & -- & . \\
\hline-- & .53 & -- & - & -- & - & -- \\
\hline
\end{tabular}

Footnotes at end of table. 
Table 10. Data requirements for the MWD_MAIN base year 1980-Continued

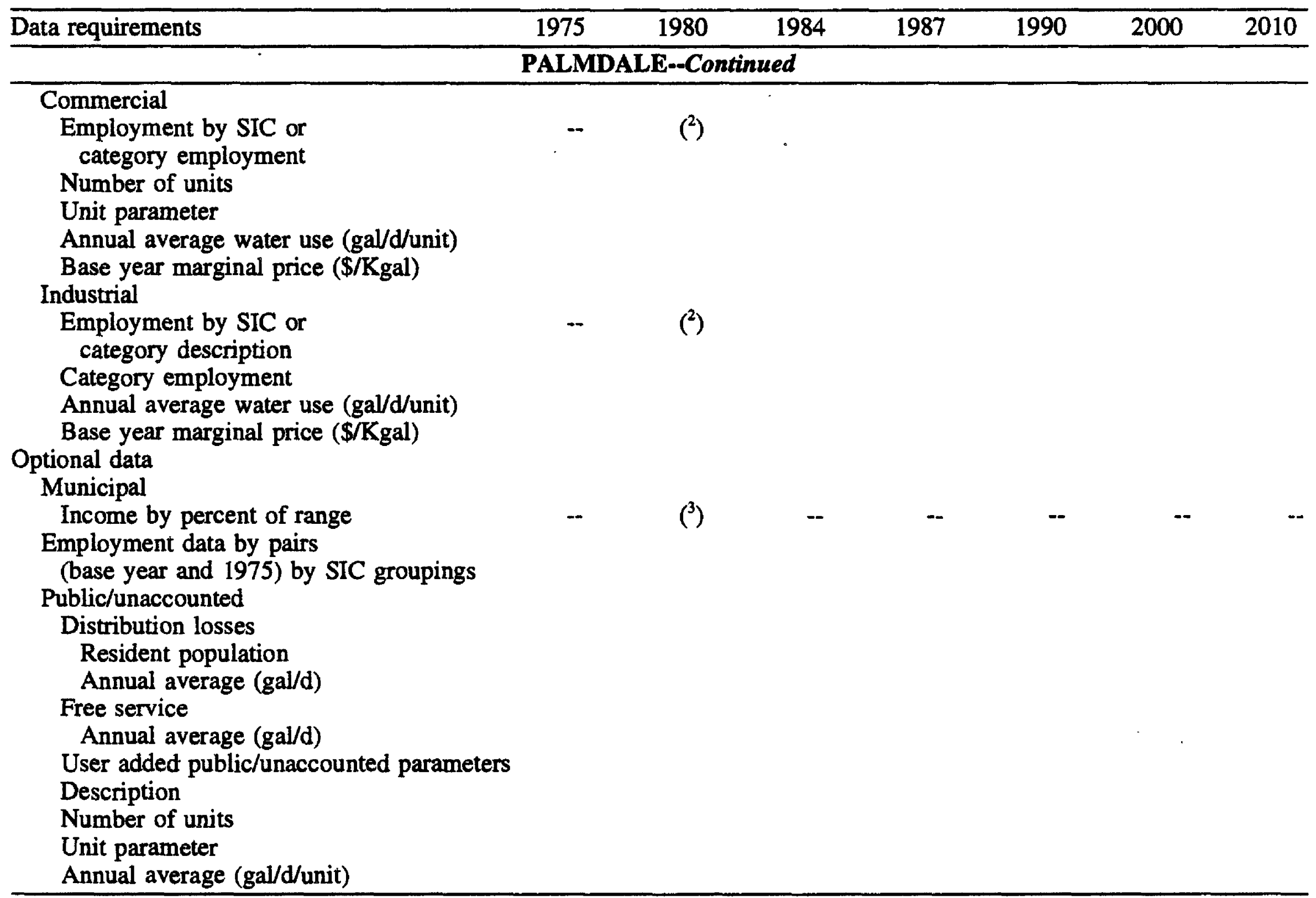

(using Lancaster housing value range distribution, weather information, and water rates)

\begin{tabular}{|c|c|c|c|c|c|c|c|}
\hline \\
\hline \multicolumn{8}{|l|}{ Municipal } \\
\hline Base year & -. & 1980 & -- & -. & -- & -- & -. \\
\hline Total population & -. & 124,350 & -- & -- & 260,400 & 504,600 & 690,000 \\
\hline Median income & -- & 21,790 & -- & -- & 25,268 & 26,784 & 28,391 \\
\hline Total employment & 50,051 & 58,865 & -- & -- & 143,564 & 472,877 & 347,200 \\
\hline $\mathrm{CCI}$ or alternate $\mathrm{CCI}$ & -. & 143.3 & -- & .- & ... & -- & -- \\
\hline Rainfall, in inches & -- & 5.7 & -- & -- & .- & -- & -- \\
\hline Maximum summer temperature & -- & 107 & -- & - & -- & -- & -- \\
\hline Cooling degree days & - & 1,635 & -- & -- & -- & .- & -- \\
\hline \multicolumn{8}{|l|}{ Residential } \\
\hline Multifamily, housing by value range & - & $\left({ }^{1}\right)$ & -- & -- & -- & -- & -- \\
\hline Multifamily, persons per unit & _- & 2.79 & -- & .- & .- & -- & -- \\
\hline Multifamily, winter rate (\$/Kgal) & -- & .44 & -- & -- & -- & -- & \\
\hline Multifamily, summer rate (\$/Kgal) & -. & .44 & -- & -- & -- & -- & \\
\hline Single family, housing by range & -- & (') & -- & -- & -- & -- & -- \\
\hline Single family, persons per unit & -- & 2.79 & -- & -- & -- & -- & -- \\
\hline Single family, winter rate ( $\$ / \mathrm{Kgal})$ & -- & .56 & -- & -- & -- & -- & \\
\hline Single family, summer rate (\$/Kgal) & -- & .56 & -- & -- & -- & _- & \\
\hline
\end{tabular}

Footnotes at end of table. 
Tabie 10. Data requirements for the MWD_MAIN base year 1980-Continued

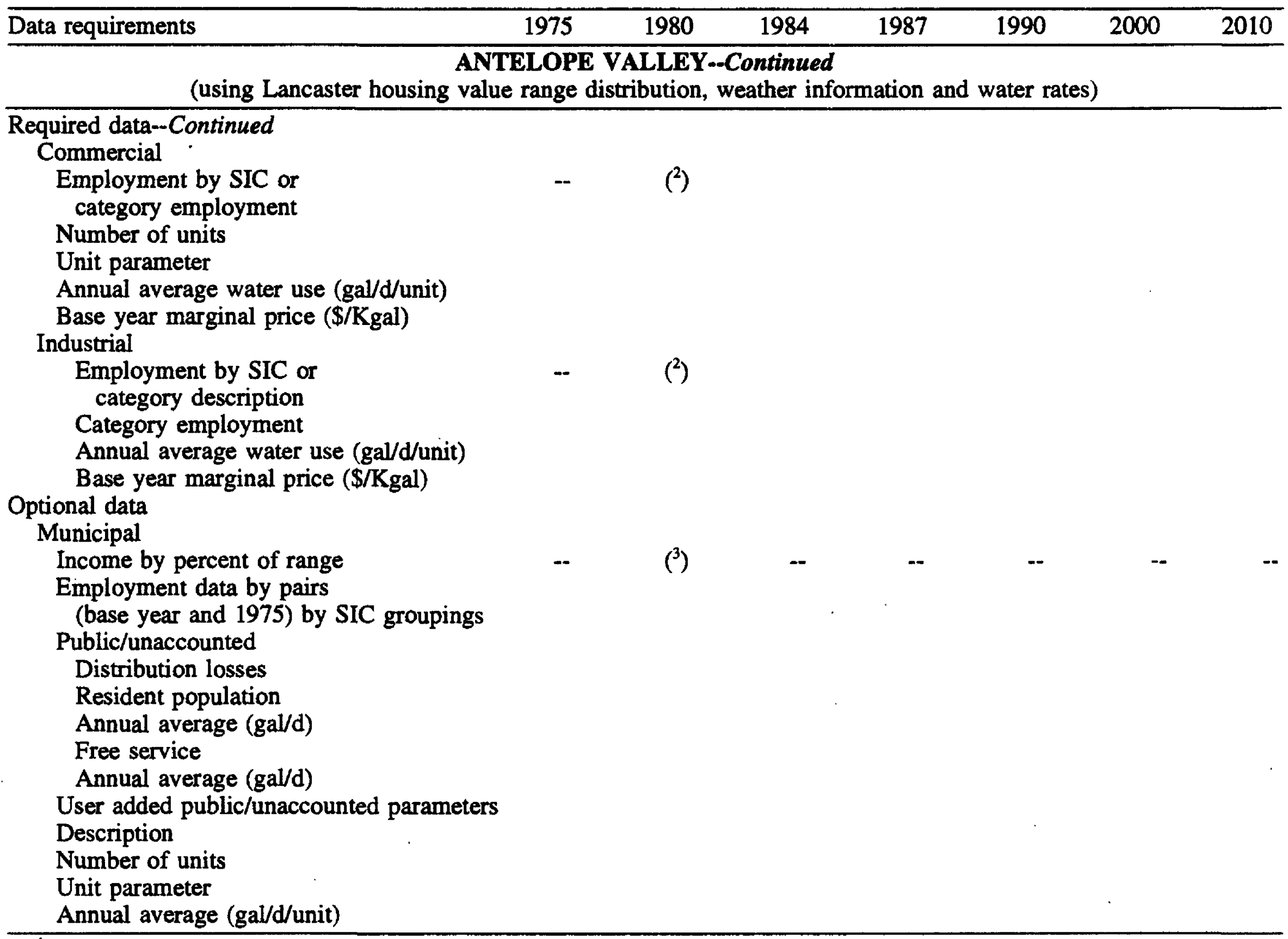

'See tables 15 and 16.

${ }^{2}$ See table 13.

${ }^{3}$ See table 14.

conservation measures. Restricted-use demand forecasts were made for Lancaster, Palmdale, and the Antelope Valley on the basis that the same "best-management practices" for water-demand reduction were used for Antelope Valley as were used in Perris Valley, a similar desert area in California (Metropolitan Water District of Southern California, 1993). These model runs were produced only for reference because no "best-management practices" have been adopted for the study area.

Attempts to forecast water demands for the Antelope Valley area were made using information available for the cities of Lancaster and Palmdale (tables 10 and 11) for which water demand was forecasted through the year 2010 (table 12).

Preliminary calibration and verification indicate that sufficient socioeconomic data presently (1994) are not available for the Antelope Valley to use the current forecasts from the MAIN system without extreme caution. Data are limited for employment (table 13), median income distributions (table 14), and housing statistics for single family (table 15) and multifamily (table 16) housing units.

Population data are available (table 17), but often are contradictory for the same year from different sources. Of the three forecasts made using the MAIN model, the Lancaster simulation contained the highest quality socioeconomic data available. The forecasts presented in table 12 indicate that the 
Table 11. Data requirements by forecast method for MWD_MAiN forecast years 1984, 1987, 1990, 2000, and 2010 for Lancaster and Palmdale

[SIC, Standard Industrial Code; --, no data available]

\section{Sources of data:}

\section{Population:}

Antelope Valley: Marla Hambright, California Department of Water Resources (written commun., 1993).

Lancaster and Palmdale: City of Lancaster (1993); Javier Minjares, Southern California Association of Governments (written commun., 1993).

\section{Employment:}

Antelope Valley Board of Trade (1993); Javier Minjares, Southern California Association of Governments (written commun., 1993); Kern County Council of Governments (1991).

\section{Income:}

Antelope Valley: Alfred Gobar and Associates (1993); Eva Opitz, Planning and Management Consultants, Ltd. (oral commun., 1993).

Lancaster and Palmdale: Javier Minjares, Southern California Association of Governments (written commun., 1993);

\section{Housing:} Kern County Council of Governments (1991).

Antelope Valley: Alfred Gobar and Associates (1993).

Lancaster and Palmdale: Javier Minjares, Southern California Association of Governments (written commun., 1993); U.S. Department of Commerce (1990).

\begin{tabular}{lrrrrr}
\hline Data requirements by type of forecast method & 1984 & 1987 & 1990 & 2000 & 2010 \\
\hline & LANCASTER & & & & \\
\hline & & & & & \\
Internal growth & 53,827 & 68,063 & 97,291 & 152,279 & 212,140 \\
$\quad$ Required data & 24,013 & 20,943 & 25,046 & 26,549 & 28,142 \\
$\quad$ Total population & 15,195 & 23,240 & 42,039 & 63,217 & 83,320 \\
$\quad$ Median income & 19,690 & 25,160 & 32,899 & 48,721 & 70,267 \\
$\quad$ Total employment & -- & -- & -- & -- & -- \\
Optional data & -- & -- & $(1)$ & -- & --
\end{tabular}

Extrapolation of data for historical data base year must be entered for sector(s) to be generated and historical data must be entered.

\section{Required data \\ Residential}

Historical years

Housing by subgroup

Single family

Multifamily

Housing, by value range

Commercial $^{2}$

Historical years

Employment by SIC

Industrial $\left({ }^{2}\right)$

(Must have base year data to use)

Historical years

Employment by SIC

(Must have base year data to use)

Optional data

Public/unaccounted

Enter historical population for distribution

Losses/free service for years specified

May enter historical parameter values for historical years chosen
Historical forecast option not used for this study

See footnotes at end of table. 
Table 11. Data requirements by forecast method for MWD_MAIN forecast years 1984, 1987, 1990, 2000. and 2010, for Lancaster and Palmade--Continued

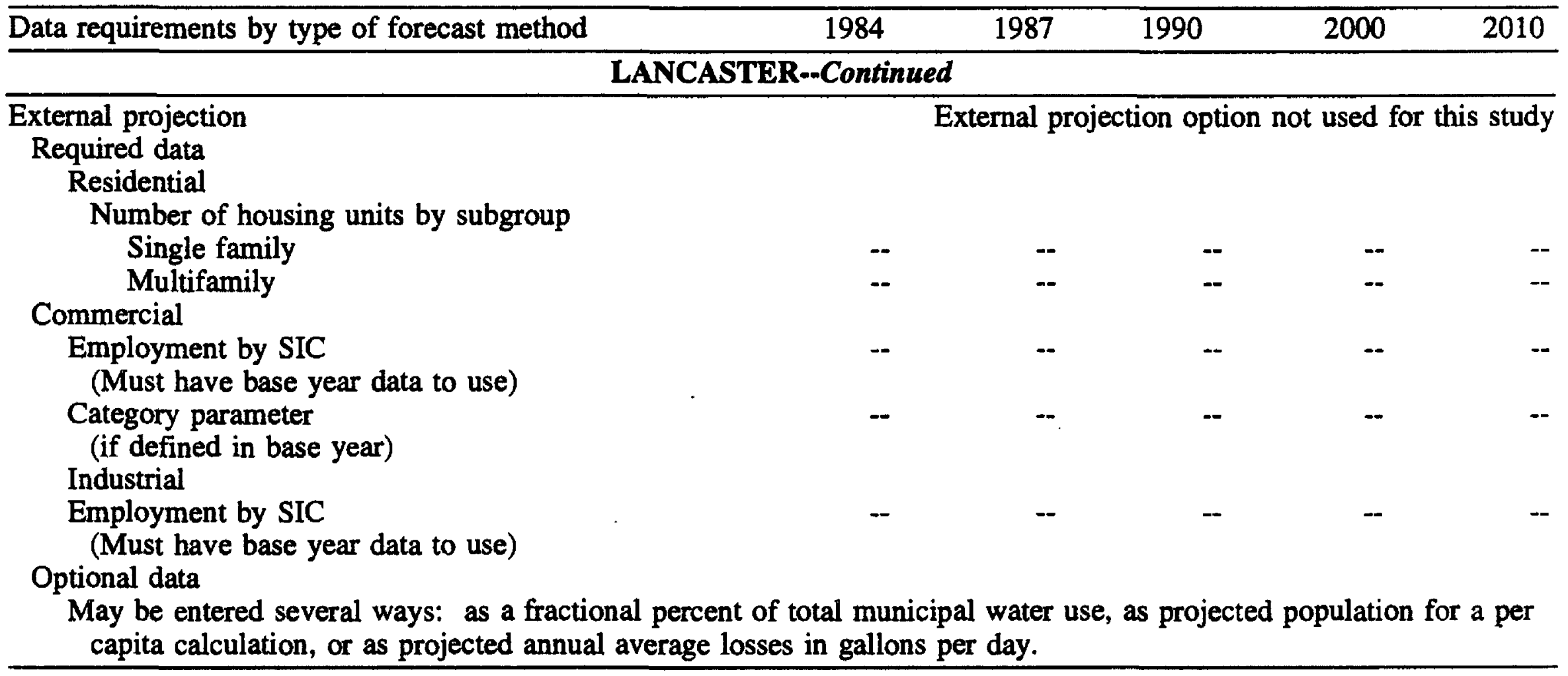

\section{PALMDALE}

\begin{tabular}{lrrrrr}
\hline Internal growth & & & & & \\
Required data & 17,711 & 33,103 & 68,842 & 161,200 & 226,425 \\
Total population & 20,363 & 18,398 & 27,386 & 29,029 & 30,771 \\
Median income & 6,400 & 10,000 & 16,075 & 34,104 & 51,621 \\
$\quad$ Total employment & & & & & \\
Optional data & 6,499 & 12,232 & 21,950 & 47,863 & 70,473 \\
$\quad$ Number of households & -- & -- & -- & -- & - \\
Percent household income groups & - & -- & $($ ) & -- & --
\end{tabular}

\section{Extrapolation of historical data}

Base year data must have been entered for sector(s) to be generated.

Must enter at least 2 historical years.

\section{Required data \\ Residential}

Historical forecast option not used for this study

Historical years

Housing by subgroup

Single family

Multifamily

Housing by value range

Commercial $^{2}$

Historical years

Employment by SIC

Industrial ${ }^{2}$

(Must have base year data to use)

Historical years

Employment by SIC

(Must have base year data to use)

Optional data

Public/unaccounted

Enter historical population for distribution

Losses/free service for years specified

May enter historical parameter values for historical years chosen

See footnotes at end of table. 
Table 11. Data requirements by forecast method for MWD_MAIN forecast years 1984, 1987, 1990, 2000. and 2010, for Lancaster and Paimdaie--Continued

\begin{tabular}{|c|c|c|c|c|c|}
\hline Data requirements by type of forecast method & 1984 & 1987 & 1990 & 2000 & 2010 \\
\hline \multicolumn{6}{|c|}{ PALMDALE-.Continued } \\
\hline External projection & \multicolumn{5}{|c|}{ External projection option not used for this study } \\
\hline \multirow{2}{*}{\multicolumn{6}{|c|}{ Required data }} \\
\hline \multicolumn{2}{|l|}{ Residential } & & & & \\
\hline \multicolumn{6}{|l|}{ Number of housing units by subgroup } \\
\hline Single family & -- & -- & -- & .- & -. \\
\hline Multifamily & -. & -- & -- & -- & - \\
\hline \multicolumn{6}{|l|}{ Commercial } \\
\hline $\begin{array}{l}\text { Employment by SIC } \\
\text { (Must have base year data to use) }\end{array}$ & -- & -- & -- & -- & -- \\
\hline $\begin{array}{l}\text { Category parameter } \\
\text { (if defined in base year) }\end{array}$ & -- & -- & -- & -- & -- \\
\hline \multicolumn{6}{|l|}{ Industrial } \\
\hline $\begin{array}{l}\text { Employment by SIC } \\
\text { (Must have base year data to use) }\end{array}$ & -- & -- & -- & -- & -- \\
\hline \multicolumn{6}{|l|}{ Optional data } \\
\hline \multicolumn{6}{|c|}{$\begin{array}{l}\text { May be entered several ways: as a fractional percent of total municipal water use, as projected population for a per } \\
\text { capita calculation, or as projected annual average losses in gallons per day. }\end{array}$} \\
\hline \multicolumn{6}{|c|}{ ANTELOPE VALLEY } \\
\hline \multicolumn{6}{|l|}{ Internal growth } \\
\hline \multicolumn{6}{|l|}{ Required data } \\
\hline Total population & -- & -- & 260,400 & 504,600 & 690,000 \\
\hline Median income & -- & -- & 25,268 & 26,784 & 28,391 \\
\hline Total employment & -- & -- & 143,564 & 472,877 & 347,200 \\
\hline \multicolumn{6}{|l|}{ Optional data } \\
\hline Number of households & -- & -- & 134,983 & 237,377 & 364,060 \\
\hline Percent household income groups & -- & -- & -- & -- & -- \\
\hline Employment by SIC & -- & -- & $\left({ }^{1}\right)$ & -- & -- \\
\hline
\end{tabular}

\section{Extrapolation of historical data}

Base year data must have been entered for sector(s) to be generated.

Must enter at least 2 historical years.

\section{Required data \\ Residential}

Historical years

Housing by subgroup

Single family

Multifamily

Housing by value range

Commercial ${ }^{2}$

Historical years

Employment by SIC

(Must have base year data to use)

Industrial $^{2}$

Historical years

Employment by SIC

(Must have base year data to use)

Optional data

Public/unaccounted

Enter historical population for distribution

Losses/free service for years specified

May enter historical parameter values for historical years chosen

See footnotes at end of table.
Historical forecast option not used for this study

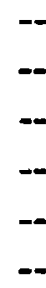

-
--
-
-

$-$

$-$

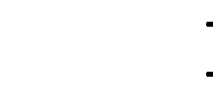


Table 11. Data requirements by forecast method for MWD_MAIN forecast years 1984, 1987, 1990, 2000 , and 2010, for Lancaster and Palmdale-Continued

\begin{tabular}{|c|c|c|c|c|c|}
\hline Data requirements by type of forecast method & 1984 & 1987 & 1990 & 2000 & 2010 \\
\hline \multicolumn{6}{|c|}{ ANTELOPE VALLEY--Continued } \\
\hline External Projection & \multirow{2}{*}{\multicolumn{5}{|c|}{ External projection option not used for this study }} \\
\hline \multicolumn{3}{|l|}{ Required data } & & & \\
\hline \multicolumn{6}{|l|}{ Residential } \\
\hline \multicolumn{6}{|l|}{ Number of housing units by subgroup } \\
\hline Single family & .- & -- & -- & _- & -- \\
\hline Multifamily & -- & -- & -- & -- & - \\
\hline \multicolumn{6}{|l|}{ Commercial } \\
\hline $\begin{array}{l}\text { Employment by SIC } \\
\text { (Must have base year data to use) }\end{array}$ & \multicolumn{4}{|c|}{ (Must have base year data to use) } & -- \\
\hline \multicolumn{5}{|l|}{ (if defined in base year) } & -- \\
\hline \multicolumn{6}{|l|}{ Industrial } \\
\hline \multicolumn{6}{|l|}{ (Must have base year data to use) } \\
\hline \multicolumn{6}{|l|}{ Optional data } \\
\hline $\begin{array}{l}\text { May be entered several ways: as a fract } \\
\text { capita calculation, or as projected annu }\end{array}$ & $1 \mathrm{mur}$ & $\begin{array}{l}\text { ipal water } \\
\text { per day. }\end{array}$ & proj & ulati & a per \\
\hline
\end{tabular}

${ }^{1}$ See table 13.

${ }^{2}$ Must have base year information for this option.

reported water demands for 1990 account for about 70 to 77 percent of the simulated water demands forecasted under unrestricted and restricted scenarios. However, none of the water suppliers in the study area have adopted "best-management practices" for water conservation that were used in simulating our restricted water-demand projections. The differences between our present simulated and reported water demands for 1990 are expected to decrease as input data for the model systems are improved and as accuracy increases in accounting for actual water demands for Lancaster, Palmdale, and the entire Antelope Valley.

Assuming that growth in water demand and projected socioeconomic variables for Lancaster are representative of the Antelope Valley, total urban water demand in the Antelope Valley is projected (using the MAIN system) to increase from about 77,168 acre-ft (actual) in 1990 (table 12 and table 18 at back of report) to about 329,000 acre-ft in 2010 (table 12). More conservative projections can be derived using the ratios of increase in urban demand forecasted (table 12) between 1990 and 2010 for Lancaster or Palmdale. The ratio of increase for Lancaster is 2.08 , determined from a reported water demand of 32,430 acre-ft in 1990 and a forecasted water demand of 67,490 acre-ft in 2010. The ratio of increase for Palmdale is 2.50 , determined from a reported water demand of 23,950 acre-ft in 1990 and a forecasted water demand of 59,940 acre-ft in 2010. Using reported total water demand of 77,168 acre-ft/yr for all urban uses for the entire Antelope Valley in 1990 and these ratios, projected urban water demands for Lancaster and Palmdale would increase between 1990 and 2010 from 23,736 acre$f t$ to 49,371 acre- $f t$ for Lancaster, from 17,192 acre$\mathrm{ft}$ to 42,980 acre-ft for Palmdale, and from 77,168 acre-ft to between 160,500 and 192,920 acre- $\mathrm{ft}$ for the Antelope Valley. A more liberal projection for total demand for all urban uses can be derived by applying the ratio of increase between 1990 and 2010 for the entire Antelope Valley $(109,910$ in 1990 to about 329,000 , or 2.99 ). Using this projection, urban water demand would increase from 77,168 acre-ft in 1990 to 230,732 acre-ft/yr by 2010.

This wide range of projected water demand $(160,500$ to 329,000 acre- $\mathrm{ft})$ is indicative of the expected error associated with the present waterdemand forecasts made using socioeconomic data currently available for the Antelope Valley. Management of local water resources is expected to be decided by members of the Antelope Valley Water Group (and other interested parties) on the basis of these projections, their best judgement, and their understanding of local conditions. In addition to potentially significant errors in population projections and other model parameters, other factors can 
Table 12. Water-demand forecast for the Antelope Valley and the cities of Lancaster and Palmdale, 1980 to 2010

[Method used: These forecasts were developed using a version of the MWD_MAIN water-demand forecasting system supplied by the Metropolitan Water District of Southern California (1993) for the Perris Valley area. The Perris Valley system was modified to reflect conditions as they presently (1994) are known for the Antelope Valley. The assumption for the best-management practices are the same as were used for Perris Valley, California, by the Metropolitan Water District of southern California to create restricted-use estimates. This assumption was made because no best-management practices have been adopted in the Antelope Valley. USGS, U.S. Geological Survey; gal/d, gallons per day; acre-ft/yr, acre feet per year; $-\cdots$, no data available]

\begin{tabular}{|c|c|c|c|c|c|c|c|}
\hline \multirow{3}{*}{$\begin{array}{l}\text { System } \\
\text { run }\end{array}$} & \multirow{3}{*}{$\begin{array}{c}\text { Forecast } \\
\text { year }\end{array}$} & \multicolumn{4}{|c|}{ Annual water-demand forecast } & \multirow{2}{*}{\multicolumn{2}{|c|}{$\begin{array}{c}\text { Reported water demand } \\
\text { use (from table } 18 \\
\text { and USGS data base) }\end{array}$}} \\
\hline & & \multirow{2}{*}{\multicolumn{2}{|c|}{$\begin{array}{l}\text { Total unrestricted use } \\
\text { (gal/d) } \\
\text { (acre-ft/yr) }\end{array}$}} & \multicolumn{2}{|c|}{$\begin{array}{l}\text { Total restricted use } \\
(\mathrm{gal} / \mathrm{d}) \quad(\text { acre-ft/yr) }\end{array}$} & & \\
\hline & & & & & & (acre-ft/yr) & $\begin{array}{l}\text { (percent }{ }^{1} \\
\text { of forecast }\end{array}$ \\
\hline \multicolumn{8}{|c|}{ ANTELOPE VALLEY ${ }^{2}$} \\
\hline 1 & 1980 & 50,215 & 56,290 & 50,215 & 56,290 & 34,879 & 62 \\
\hline 2 & 1990 & 98,044 & 109,910 & 95,886 & 107,490 & 77,168 & $70 / 72$ \\
\hline 3 & 2000 & 236,179 & 264,760 & 225,638 & 252,940 & -- & $\ldots$ \\
\hline 4 & 2010 & 293,246 & 328,730 & 278,367 & 312,050 & -- & $\ldots$ \\
\hline \multicolumn{8}{|c|}{ LANCASTER } \\
\hline$\overline{1}$ & 1980 & 15,620 & 17,510 & 15,620 & 17,510 & 13,820 & 79 \\
\hline 2 & 1990 & 28,932 & 32,430 & 27,325 & 30,630 & 23,736 & $73 / 77$ \\
\hline 3 & 2000 & 43,192 & 48,420 & 39,283 & 44,040 & -- & 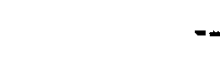 \\
\hline 4 & 2010 & 60,203 & 67,490 & 52,147 & 59,350 & -- & - \\
\hline \multicolumn{8}{|c|}{ PALMDALE } \\
\hline 1 & 1980 & 5,973 & 6,700 & 5,973 & 6,700 & 6,130 & 91 \\
\hline 2 & 1990 & 21,362 & 23,950 & 20,169 & 22,610 & 17,192 & $72 / 76$ \\
\hline 3 & 2000 & 37,812 & 42,390 & 34,546 & 38,730 & -- & .. \\
\hline 4 & 2010 & 53,467 & 59,940 & 47,137 & 52,840 & -- & -. \\
\hline
\end{tabular}

${ }^{1}$ Percent of forecasted demand that is accounted for in our data base (table 18). The difference between reported and forecasted could be due to incomplete reporting and/or unrefined forecast data for the Antelope Valley forecasts. Another potential source of error for the Lancaster and Palmdale forecasts occurs when determining the actual deliveries to each city by each water supplier when city and water boundaries are different.

${ }^{2}$ Housing values, water rates, and winter rainfall for Lancaster and the Antelope Valley.

affect future water demands, including construction of the proposed international airport and high-speed rail systems. Water-conservation options may be adopted along with other current best-management practices to help better manage future water demands in the Antelope Valley. Because estimated increases in water demand are relative to increases in population, most of the increase in water demand in the Antelope Valley is expected to be for urban uses. Population projections for 2010 show that the population, which was probably between 250,510 and 273,443 in 1990 according to available reports, could increase to 738,000 in 2010 and 986,000 by 2020 , which represent increases of 295 and 394 percent, respectively (table 17).

\section{Dlsaggregated Factor Forecasts}

An alternative approach to MAIN system forecasts, which may be more appropriate in areas of limited data availability such as the Antelope Valley, is the Disaggregated Factor Forecast (DFF) method. The DFF is a simplified version of the MAIN system which can provide a sectoralized result. This method reportedly could be used on a simple spreadsheet or with a hand-held calculator. Advantages of this method include simplicity, ease in use, and fewer data requirements; the primary disadvantage is a loss in accuracy. Because of the anticipated loss in accuracy, this method has not yet been applied in the Antelope Valley. However, 
Table 13. Employment data for the Antelope Valley by Standard industrial Code (SIC)

$[--$, no data available $]$

Sources of data:

Employment by Standard Industrial Code (SIC):

Southern California Association of Governments (1993); Pete Smith, Kern County Council of Governments (written commun., 1993).

Total employment:

Southern California Association of Governments (1993); Alfred Gobar and Associates (1993).

\begin{tabular}{|c|c|c|c|c|c|c|c|c|c|}
\hline \multirow{2}{*}{$\begin{array}{l}\text { Subcategory } \\
\text { (code and name) } \\
\text { or SIC }\end{array}$} & \multicolumn{3}{|c|}{ Lancaster } & \multicolumn{3}{|c|}{ Palmdale } & \multicolumn{3}{|c|}{ Los Angeles County } \\
\hline & 1975 & 1980 & 1990 & 1975 & 1980 & 1990 & 1975 & 1980 & 1990 \\
\hline$\overline{\text { C001 Miscellaneous }}$ & & & & & & & & & \\
\hline commercial & -- & 3,397 & 5,988 & -- & 1,019 & 2,371 & -- & 6,353 & 10,916 \\
\hline $\begin{array}{l}\text { C002 Vocational schools } \\
\text { C003 Miscellaneous }\end{array}$ & -- & 524 & 1,091 & -- & 120 & 272 & -- & 880 & 1,512 \\
\hline retail & -- & 1,908 & 4,054 & -- & 622 & 1,413 & -- & 3,767 & 6,473 \\
\hline $\begin{array}{l}\text { C004 Boarding houses } \\
\text { C005 Transoortation }\end{array}$ & -- & -- & -- & -- & 7 & 17 & -- & 17 & 30 \\
\hline $\begin{array}{l}\text { terminals } \\
\text { C006 Laundries }\end{array}$ & -- & -- & -- & -- & -- & -- & -- & 1 & 2 \\
\hline and cleaning & -- & 335 & 695 & -- & 132 & 300 & -- & 616 & 1,058 \\
\hline $\begin{array}{l}\text { C007 Power laundries } \\
\text { C008 Landscaping }\end{array}$ & - & - & -- & -- & 4 & 8 & -- & 5 & 8 \\
\hline $\begin{array}{l}\text { services } \\
\text { C009 Miscellaneous }\end{array}$ & -- & 51 & 171 & -- & 7 & 16 & - & 78 & 143 \\
\hline $\begin{array}{l}\text { wholesale } \\
\text { C010 Recreational }\end{array}$ & -- & 3,095 & 6,882 & -- & 885 & 2,011 & - & 6,002 & 10,312 \\
\hline $\begin{array}{l}\text { facilities } \\
\text { C011 Food and }\end{array}$ & -- & 4 & 8 & -- & 2 & 4 & - & 3 & 53 \\
\hline other retail & -- & 1,261 & 2,655 & -- & 414 & 942 & -- & 2,347 & 4,033 \\
\hline $\begin{array}{l}\text { C012 Art schools } \\
\text { C013 Hotels and }\end{array}$ & -- & 7 & 15 & - & 1 & 3 & -- & 10 & 18 \\
\hline $\begin{array}{l}\text { restaurants } \\
\text { C014 Electric and }\end{array}$ & - & 1,679 & 2,369 & - & 468 & 1,064 & -- & 2,169 & 3,727 \\
\hline $\begin{array}{l}\text { gas utilities } \\
\text { C015 Public }\end{array}$ & -- & 31 & 66 & -- & 54 & 122 & -- & 120 & 206 \\
\hline $\begin{array}{l}\text { administration } \\
\text { C016 Schools and }\end{array}$ & -- & 3,602 & 7,503 & -- & 4,446 & 10,151 & $\cdots$ & 5,923 & 10,177 \\
\hline universities & -- & 1,256 & 2,616 & -- & 4,400 & 10,000 & -- & 3,047 & 5,236 \\
\hline C017 Racetracks & -- & 1 & 3 & -- & 1 & 3. & -- & 3 & 6 \\
\hline $\begin{array}{l}\text { C018 Car washes } \\
\text { and laboratories }\end{array}$ & $=$ & & & & & & & & \\
\hline C019 Health services & - & $\begin{array}{l}122 \\
107\end{array}$ & $\begin{array}{l}253 \\
223\end{array}$ & $\because$ & $\begin{array}{l}12 \\
--\end{array}$ & $\begin{array}{l}27 \\
-.\end{array}$ & -- & $\begin{array}{l}191 \\
136\end{array}$ & $\begin{array}{l}329 \\
234\end{array}$ \\
\hline $\begin{array}{l}\text { C020 Medical offices } \\
\text { C021 Nursing }\end{array}$ & -- & 2,038 & 3,605 & -- & 134 & 304 &.- & 2,266 & 3,893 \\
\hline facilities & -- & 416 & 868 & -- & -- & -- & -- & 644 & 1,107 \\
\hline C022 Hospitals & -- & 1,279 & 2,644 & -- & 189 & 202 & -- & 1,680 & 2,866 \\
\hline C023 Botanical and & & & & & & & & & \\
\hline $\begin{array}{l}\text { zoological gardens } \\
\text { Manufacturing }\end{array}$ & -- & -- & -- & -- & -- & - & -- & -- & - \\
\hline 201 & -- & 2 & 4 & -- & -. & -. & -- & 2 & 4 \\
\hline 205 & -- & 5 & 10 & -- & 1 & 3 & -- & 8 & \\
\hline 208 & -- & 26 & 55 & -- & 7 & 15 & -- & 41 & 70 \\
\hline 209 & -- & 1 & 3 & -- & -- & -- & - & 2 & 3 \\
\hline 222 & -- & -- & -- & -- & -- & -- & - & - & -- \\
\hline 233 & -- & -- & -- & -- & -- & -- & -- & -- & - \\
\hline
\end{tabular}


Table 13. Employment data for the Antelope Valley by Standard Industrlal Code (SIC)-Continued

\begin{tabular}{|c|c|c|c|c|c|c|c|c|c|}
\hline \multirow{2}{*}{$\begin{array}{c}\text { Subcategory } \\
\text { (code and name) } \\
\text { or SIC }\end{array}$} & \multicolumn{3}{|c|}{ Lancaster } & \multicolumn{3}{|c|}{ Palmdale } & \multicolumn{3}{|c|}{ Los Angeles County } \\
\hline & 1975 & 1980 & 1990 & 1975 & 1980 & 1990 & 1975 & 1980 & 1990 \\
\hline \multicolumn{10}{|c|}{ Manufacturing--Continued } \\
\hline 239 & -- & 1 & 1 & -- & -- & -- & -- & 1 & 1 \\
\hline 242 & -- & 1 & 2 & -- & - & -- & -- & 25 & 47 \\
\hline 243 & -- & 10 & 19 & -- & 1 & 3 & -- & 12 & 22 \\
\hline 245 & -- & -- & -- & -- & -- & -- & -- & 18 & 35 \\
\hline 249 & -- & 5 & 10 & -- & -- & -- & -- & 8 & 14 \\
\hline 251 & -- & 18 & 38 & -- & -- & -- & -- & 22 & 38 \\
\hline 254 & -- & 2 & 5 & -- & 5 & 12 & -- & 12 & 20 \\
\hline 259 & -- & 14 & 29 & -- & -- & -- & -- & 20 & 35 \\
\hline 265 & -- & 27 & 56 & -- & 25 & 56 & - & 65 & 112 \\
\hline 271 & -- & 32 & 66 & -- & 93 & 212 & -- & 162 & 278 \\
\hline 272 & -- & 5 & 11 & -. & -- & -- & -- & 6 & 11 \\
\hline 273 & -- & -- & - & -- & 1 & 1 & -- & 2 & 3 \\
\hline 274 & .. & 26 & 55 & -- & -. & -- & .. & 32 & 55 \\
\hline 275 & -- & 52 & 108 & -- & 28 & 62 & -- & 105 & 171 \\
\hline 279 & -- & -- & -- & -- & -- & -- & -- & 2 & 3 \\
\hline 281 & -- & 1 & 2 & -- & -- & -- & -- & 1 & 2 \\
\hline 282 & -- & 1 & 2 & -- & -- & -- & -- & 1 & 2 \\
\hline 283 & -- & 1 & 3 & - & -- & -- & -- & 2 & 3 \\
\hline 286 & -- & -- & -- & -- & -- & -- & -- & 4 & 4 \\
\hline 289 & -- & -- & -- & - & -- & -- & - & -- & -- \\
\hline 291 & -- & -- & -- & -- & 3 & 6 & -- & 3 & 6 \\
\hline 306 & -- & -- & -- & -- & -- & -. & -- & 1 & 2 \\
\hline 308 & -- & 9 & 19 & -- & 5 & 12 & -- & 19 & 33 \\
\hline 323 & -- & 5 & 11 & -. & -- & -- & -- & 9 & 15 \\
\hline 324 & $\cdots$ & -- & -- & -- & -- & -- & - & 61 & 105 \\
\hline 325 & -- & 3 & 6 & - & -- & -- & -- & 3 & 6 \\
\hline 326 & -- & -- & -- & -- & 1 & 3 & - & 2 & 3 \\
\hline 327 & -- & 36 & 76 & -- & 26 & 60 & -- & 80 & 138 \\
\hline 328 & -- & 4 & 9 & -- & & -- & -- & -- & 5 \\
\hline 329 & -- & -- & -- & -- & -- & -- & -- & -- & -- \\
\hline 333 & -- & -- & - & -- & -- & .- & -- & .- & -- \\
\hline 336 & - & 11 & 22 & -. & -- & -- & -- & 13 & 22 \\
\hline 343 & - & -- & $\cdots$ & -- & -- & -- & -- & 87 & 150 \\
\hline 344 & - & 36 & 76 & -- & 12 & 27 & -- & 57 & 98 \\
\hline 345 & $\ldots$ & 1 & 3 & -- & -- & -- & -- & 13 & 21 \\
\hline 347 & $\cdots$ & 11 & 24 & -- & 6 & 14 & -- & 25 & 42 \\
\hline 348 & $\cdots$ & 1 & 2 & -- & .- & -- & -- & 1 & 2 \\
\hline 349 & - & -- & -- & -- & -- & -- & -- & -- & -. \\
\hline 351 & - & -- & -- & -- & 3 & 6 & -- & 3 & 6 \\
\hline 354 & - & 6 & 15 & - & 4 & 9 & -- & 20 & 34 \\
\hline 355 & -. & 1 & 1 & -- & 5 & 11 & -- & 9 & 15 \\
\hline 356 & - & 6 & 13 & -- & -- & -- & -- & 15 & 26 \\
\hline 358 & -- & 1 & 1 & -- & -- & $\cdots$ & -. & 5 & 9 \\
\hline 359 & -- & 32 & 66 & -- & 18 & 42 & -- & 159 & 258 \\
\hline 362 & -- & -- & -- & -- & 2 & 5 & -- & 19 & 34 \\
\hline 364 & -- & 3 & 7 & -- & -- & -- & -- & 4 & 7 \\
\hline 365 & -- & -- & -- & -- & -- & -- & -- & -- & -- \\
\hline 367 & -- & 11 & 23 & -- & 1 & 2 & -- & 14 & 25 \\
\hline
\end{tabular}


Table 13. Employment data for the Antelope Valley by Standard Industrial Code (SIC)-Continued

\begin{tabular}{|c|c|c|c|c|c|c|c|c|c|}
\hline \multirow{2}{*}{$\begin{array}{l}\text { Subcategory } \\
\text { (code and name) } \\
\text { or SIC }\end{array}$} & \multicolumn{3}{|c|}{ Lancaster } & \multicolumn{3}{|c|}{ Palmdale } & \multicolumn{3}{|c|}{ Los Angeles County } \\
\hline & 1975 & 1980 & 1990 & 1975 & 1980 & 1990 & 1975 & 1980 & 1990 \\
\hline \multicolumn{10}{|l|}{ Manufacturing--Continued } \\
\hline 369 & -- & 1 & 2 & -- & -- & -- & -- & 1 & 2 \\
\hline 371 & -- & 6 & 13 & -. & 3 & 7 & -- & 16 & 27 \\
\hline 372 & -- & 385 & 803 & -- & 95 & 216 & -- & 4,733 & 8,133 \\
\hline 373 & -- & -- & -- & -- & -- & -- & -- & 524 & 901 \\
\hline 375 & -- & -- & -- & -- & -- & -- & -- & -- & -- \\
\hline 381 & -. & -. & -- & -- & 3 & 6 & -- & 3 & 6 \\
\hline 382 & -- & 6 & 12 & -- & -- & -- & -- & 14 & 23 \\
\hline 386 & -- & 1 & 2 & -- & -- & -- & -- & 1 & 2 \\
\hline 387 & -- & -- & -- & -- & 3 & 7 & -- & 4 & 7 \\
\hline 391 & -- & 1 & 3 & -- & 1 & 2 & -- & 3 & 5 \\
\hline 393 & -- & 1 & 2 & -- & -- & -- & -- & 3 & 6 \\
\hline 394 & -- & 2 & 4 & -- & -- & -- & -- & -- & -- \\
\hline 395 & -- & 3 & 6 & -- & 1 & 1 & -- & 7 & 12 \\
\hline 399 & $\cdots$ & 148 & 340 & -- & 154 & 347 & - & 97 & 167 \\
\hline \multicolumn{10}{|l|}{ Total employment } \\
\hline by subcategory or SIC & -. & 22,074 & 43,749 & .. & 13,424 & 30,377 & -- & 42,839 & 73,625 \\
\hline Total employment & 15,516 & 14,808 & 42,039 & 5,358 & 7,081 & 16,075 & 42,055 & 50,500 & 131,715 \\
\hline \multirow{2}{*}{$\begin{array}{c}\text { Subcategory } \\
\text { (code and name) } \\
\text { or SIC }\end{array}$} & \multicolumn{4}{|c|}{ Kern County } & & \multicolumn{4}{|c|}{ Antelope Valley } \\
\hline & & & 1980 & 1990 & & 1975 & & 1980 & 1990 \\
\hline \multicolumn{10}{|l|}{$\overline{\text { C001 Miscellaneous }}$} \\
\hline commercial & & -- & 1,990 & 3,420 & & -- & & 8,253 & 14,336 \\
\hline CO02 Vocational schools & & -- & 73 & 125 & & -- & & 161 & 1,637 \\
\hline \multicolumn{10}{|l|}{ C003 Miscellaneous } \\
\hline retail & & -- & 222 & 382 & & -- & & 3,989 & 6,855 \\
\hline C004 Boarding houses & & -. & 3 & 6 & & -- & & 20 & 36 \\
\hline \multicolumn{10}{|l|}{ C005 Transportation } \\
\hline terminals & & - & 31 & 53 & & -- & & 32 & 55 \\
\hline \multicolumn{10}{|l|}{ C006 Laundries } \\
\hline and cleaning & & .. & 16 & 28 & & -- & & 632 & 1,086 \\
\hline C007 Power laundries & & -- & 7 & 12 & & -- & & 12 & 20 \\
\hline \multicolumn{10}{|l|}{ C008 Landscaping } \\
\hline services & & - & 2 & 3 & & -- & & 80 & 146 \\
\hline \multicolumn{10}{|l|}{ C009 Miscellaneous } \\
\hline wholesale & & -- & 194 & 334 & & -- & & 6,336 & 10,646 \\
\hline \multicolumn{10}{|l|}{ C010 Recreational } \\
\hline facilities & & -- & -- & -- & & -- & & 31 & 53 \\
\hline \multicolumn{10}{|l|}{ C011 Food and } \\
\hline other retail & & -- & 280 & 481 & & -- & & 2,627 & 4,514 \\
\hline C012 Art schools & & -- & -- & -- & & -- & & 10 & 18 \\
\hline \multicolumn{10}{|l|}{ C013 Hotels and } \\
\hline restaurants & & -- & 315 & 542 & & -- & & 2,484 & 4,269 \\
\hline \multicolumn{10}{|l|}{ C014 Electric and } \\
\hline $\begin{array}{l}\text { gas utulities } \\
\text { C015 Public }\end{array}$ & & -- & 38 & 66 & & - & & 158 & 272 \\
\hline $\begin{array}{l}\text { administration } \\
\text { C016 Schools and }\end{array}$ & & -- & 164 & 281 & & - & & 6,087 & 10,458 \\
\hline universities & & -- & 410 & 705 & & -- & & 3,457 & 5,941 \\
\hline C017 Racetracks & & -- & 1 & 2 & & -- & & 4 & 8 \\
\hline C018 Car washes & & & & & & & & & \\
\hline and laboratories & & -- & 17 & 29 & & -- & & 208 & 358 \\
\hline
\end{tabular}


Table 13. Employment data for the Antelope Valley by Standard Industrial Code (SIC)-Continued

\begin{tabular}{|c|c|c|c|c|c|c|}
\hline \multirow{2}{*}{$\begin{array}{c}\text { Subcategory } \\
\text { (code and name) } \\
\text { or SIC }\end{array}$} & \multicolumn{3}{|c|}{ Kern County } & \multicolumn{3}{|c|}{ Antelope Valley } \\
\hline & 1975 & 1980 & 1990 & 1975 & 1980 & 1990 \\
\hline C019 Health services & $\overline{-}$ & - & -- & -- & 136 & 234 \\
\hline C020 Medical offices & .. & 12 & 20 & .- & 2,278 & 3,913 \\
\hline \multicolumn{7}{|l|}{ C021 Nursing } \\
\hline facilities & -. & - & -- & .- & 644 & 1,107 \\
\hline C022 Hospitals & -- & -- & -- & -. & 1,680 & 2,866 \\
\hline C023 Botanical and & & & & & & \\
\hline zoological gardens & - & -- & -- & -- & -- & -- \\
\hline \multicolumn{7}{|l|}{ Manufacturing } \\
\hline 201 & -- & - & -- & -- & 2 & 4 \\
\hline 205 & -- & -- & -- & -- & 8 & 13 \\
\hline 208 & -- & - & - & -- & 41 & 70 \\
\hline 209 & -- & -- & -- & $\ldots$ & 2 & 3 \\
\hline 222 & -- & 6 & 10 & -- & 6 & 10 \\
\hline 233 & -. & 1 & 1 & -. & 1 & 1 \\
\hline 239 & -- & - & $\ldots$ & -. & 1 & 1 \\
\hline 242 & -- & -- & - & -- & 25 & 47 \\
\hline 243 & .- & 16 & 27 & -- & 32 & 50 \\
\hline 245 & -- & - & -- & -- & 18 & 35 \\
\hline 249 & -- & 2 & 3 & -- & 10 & 17 \\
\hline 251 & .- & $\ldots$ & -. & .- & 22 & 38 \\
\hline 254 & -- & -- & -- & -- & 12 & 20 \\
\hline 259 & -- & -- & .. & -.. & 20 & 35 \\
\hline 265 & -- & -- & -- & -- & 65 & 112 \\
\hline 271 & -- & 1 & 2 & -- & 163 & 280 \\
\hline 272 & -- & - & $=$ & - & 6 & 11 \\
\hline 273 & .. & -- & -- & -. & 2 & 3 \\
\hline 274 & -- & - & -- & -. & 32 & 55 \\
\hline 275 & -- & 2 & 3 & - & 107 & 183 \\
\hline 279 & -- & 1 & 1 & - & 3 & 4 \\
\hline 281 & -. & 582 & 1,000 & - & 583 & 1,002 \\
\hline 282 & -- & - & -. & $\ldots$ & 1 & 2 \\
\hline 283 & -- & $\cdots$ & .. & -- & 2 & 3 \\
\hline 286 & -- & -- & -- & -- & 4 & 4 \\
\hline 289 & -- & 2 & 3 & -- & 2 & 3 \\
\hline 291 & -- & - & .- & -- & 3 & 6 \\
\hline 306 & -- & -- & -- & -. & 1 & 2 \\
\hline 308 & -- & .. & -. & .. & 19 & 33 \\
\hline 323 & -- & - & -- & - & 9 & 15 \\
\hline 324 & -- & 99 & 170 & -. & 160 & 275 \\
\hline 325 & -- & -- & -- & -. & 3 & 6 \\
\hline 326 & -- & - & -. & -- & 2 & 3 \\
\hline 327 & -- & -- & -- & -.. & 80 & 138 \\
\hline 328 & .- & -- & .- & $\ldots$ & 5 & 8 \\
\hline 329 & ... & 12 & 20 & .. & 12 & 20 \\
\hline 333 & -- & 12 & 21 & .- & 12 & 21 \\
\hline 336 & -. & -- & -. & -- & 13 & 22 \\
\hline 343 & .- & -. & .- & -- & 87 & 150 \\
\hline 344 & -. & -. & -- & -. & 57 & 98 \\
\hline 345 & .. & .- & .- & .. & 13 & 21 \\
\hline 347 & -. & -. & .- & -.. & 25 & 42 \\
\hline
\end{tabular}


Table 13. Employment data for the Antelope Valley by Standard Industrial Code (SIC)-Continued

\begin{tabular}{|c|c|c|c|c|c|c|}
\hline \multirow{2}{*}{$\begin{array}{c}\text { Subcategory } \\
\text { (code and name) } \\
\text { or SIC }\end{array}$} & \multicolumn{3}{|c|}{ Kern County } & \multicolumn{3}{|c|}{ Antelope Valley } \\
\hline & 1975 & 1980 & 1990 & 1975 & 1980 & 1990 \\
\hline \multicolumn{7}{|l|}{ Manufacturing-Continued } \\
\hline 348 & .- & .- & $\ldots$ & -. & 1 & 2 \\
\hline 349 & -. & 3 & 5 & -- & 3 & 5 \\
\hline 351 & -- & -- & -- & -. & 3 & 6 \\
\hline 354 & -- & -- & -- & -- & 20 & 34 \\
\hline 355 & _- & -- & _- & -- & 9 & 15 \\
\hline 356 & -- & -- & -. & -. & 15 & 26 \\
\hline 358 & -- & -- & -. & -. & 5 & 9 \\
\hline 359 & -- & 57 & 98 & -. & 207 & 356 \\
\hline 362 & -- & - & -- & -- & 19 & 34 \\
\hline 364 & -- & - & -- & -- & 4 & 7 \\
\hline 365 & -- & 2 & 3 & -- & 2 & 3 \\
\hline 367 & _- & -- & -- & -- & 14 & 25 \\
\hline 369 & -- & 10 & 17 & -- & 11 & 19 \\
\hline 371 & -- & 43 & 74 & -- & 55 & 101 \\
\hline 372 & -- & 121 & 207 & -- & 4,854 & 8,340 \\
\hline 373 & -- & -- & -- & $\ldots$ & 524 & 901 \\
\hline 375 & -- & 2 & 4 & -- & 2 & 4 \\
\hline 381 & -- & -- & _- & -- & 3 & 6 \\
\hline 382 & -- & 29 & 50 & -- & 43 & 73 \\
\hline 386 & -- & - & - & -- & 1 & 2 \\
\hline 387 & -- & -- & -- & -- & 4 & 7 \\
\hline 391 & -- & - & -- & -- & 3 & 5 \\
\hline 393 & -- & -- & -- & -- & 3 & 6 \\
\hline 394 & -- & 47 & 80 & -- & 47 & 80 \\
\hline 395 & -- & - & -. & -- & 7 & 12 \\
\hline 399 & -- & -- & .. & -- & 97 & 167 \\
\hline \multicolumn{7}{|l|}{ Total employment } \\
\hline by subcategory or SIC & -. & 4,825 & 8,288 & - & 46,946 & 81,939 \\
\hline Total employment & 7,996 & 8,365 & 11,849 & 50,051 & 58,865 & 143,564 \\
\hline
\end{tabular}

now that interim forecasts have been made with the MAIN systems, it may be valuable during the next iteration of forecasting to see how close the estimate might be if this method is used.

\section{Forecasts for Military Installatlons}

The interim water-demand forecasts made in this report for the Antelope Valley using the MWD_MAIN system have included Edwards Air Force Base in the public-supplied category. This inclusion is justified because Edwards Air Force Base is a licensed public water supplier. However, water-demand forecasts for military installations are not adequate when using the MAIN system because MAIN requires Standard Industrial Classifications, which are not available for military base activities.
The need for water-supply planning at military installations resulted in the development of a specialized system called IWRAPS (Installation Water Resources and Planning System) that can produce water-demand forecasts for military installations during peacetime and mobilization scenarios. IWRAPS is based on parameters that are available for military bases, such as square footage of installations, weather, and irrigated acreage. This system was developed by Planning and Management Consultants, Ltd., under contract to the U.S. Army Corps of Engineers. IWRAPS is based on information that identifies areas of specific water use at a military installation by specific function, which is based on the mission of the installation. A new version of IWRAPS, developed specifically for air force bases, was successfully applied at Vandenberg Air Force Base in Santa Barbara 
Table 14. Median Income distribution for the Antelope Valley

$[--$, no data available $]$

Sources of data:

Income: Javier Minjares, Southern California Association of Governments (written commun., 1993) for Lancaster and

Palmdale incomes in 1980, 1984, 1987, and 1990; Alfred Gobar and Associates (1993) for Antelope Valley incomes in 1980 and 1990. Eva Opitz, Planning and Management Consultants, Ltd. (written commun., 1993) for 2000 and 2010.

Consumer Price Index, for the Los Angeles/Long Beach area, Frank Nion, Southern California Association of

Governments (written commun., 1993). All reported income figures were adjusted to 1980 dollar values using the

Consumer Price Index for the Los Angeles/Long Beach area (Javier Minjaries, Southern California Association of

Governments, written commun., 1993). Income forecasts were projected using a 6-percent increase per 10-year period,

which is consistent with income forecasts for Los Angeles County used in the MAIN systems from Metropolitan Water

District of Southern California (Eva Opitz, Planning and Management Consultants, Ltd., oral commun., 1993). Income

distributions for 1980, U.S. Department of Commerce (1980) for Lancaster and Palmdale and Alfred Gobar and

Associates (1993) for the Antelope Valley.

\begin{tabular}{lrrrr}
\hline \multirow{2}{*}{ Location } & $\begin{array}{c}\text { Median } \\
\text { income }\end{array}$ & \multicolumn{3}{c}{ Income, in percent } \\
\cline { 3 - 5 } & & $\$ 0-\$ 10,000$ & $\$ 10,000-\$ 20,000$ & $\$ 20,000-\$ 30,000$ \\
\hline Lancaster $\ldots \ldots \ldots \ldots \ldots \ldots$ & $\$ 24,499$ & 22 & 27 & 24 \\
Palmdale $\ldots \ldots \ldots \ldots \ldots$ & 21,838 & 26 & 26 & 25 \\
Antelope Valley . . $\ldots \ldots \ldots$ & 21,790 & 25 & 28.1 & 25.4
\end{tabular}

\section{Forecast years}

1984

Lancaster $\ldots \ldots \ldots \ldots \ldots \ldots \ldots \ldots \ldots$

Palmdale ........... 20,363

Antelope Valley .......... -..

Lancaster . . . . . . . . . . $\$ 20,943$

Palmdale . . . . . . . . . . . 18,398

Antelope Valley . . . . . . . .

--

$\ddot{--}$

1987

$\begin{array}{lr} & \\ & \\ \text { Lancaster } \ldots \ldots \ldots \ldots \ldots \ldots & \$ 25,046 \\ \text { Palmdale } \ldots \ldots \ldots \ldots \ldots \ldots & 27,386 \\ \text { Antelope Valley . . . . . . . } & 25,268\end{array}$

1990

Lancaster . . . . . . . . . . \$26,549

Palmdale . . . . . . . . . . . . 29,029

Antelope Valley . . . . . . . 26,784

26,784

2010

Lancaster . . . . . . . . . . \$28, 142

Palmdale . . . . . . . . . . . 30,771

Antelope Valley . . . . . . . . . 28,391

\begin{tabular}{lll}
- & -- & - \\
- & -- & - \\
- & -- & - \\
\hline
\end{tabular}


Table 15. Housing statistics for single-family housing in the Antelope Valley

Sources of data:

Housing by value ranges: U.S. Department of Commerce (1980).

Total single-family housing:

Lancaster and Palmdale: Javier Minjares, Southern California Association of Governments (written commun., 1993).

Antelope Valley: Alfred Gobar and Associates (1993).

Persons per household:

Lancaster and Palmdale: Persons per owner occupied total, U.S. Department of Commerce (1980, 1990).

Antelope Valley: Alfred Gobar and Associates (1993).

Forecast year projections:

Lancaster and Palmdale: Javier Minjares, Southern California Association of Governments (written commun., 1993).

\begin{tabular}{|c|c|c|c|c|}
\hline \multirow{3}{*}{$\begin{array}{l}\text { Value range } \\
\text { (in } \$ 100^{\prime} s \text { ) }\end{array}$} & \multicolumn{4}{|c|}{ Number of houses in each value range } \\
\hline & \multirow[b]{2}{*}{ Lancaster } & \multirow[b]{2}{*}{ Palmdale } & \multicolumn{2}{|c|}{ Antelope Valley } \\
\hline & & & $\begin{array}{l}\text { Forecast } 1 \\
\text { (Lancaster) }\end{array}$ & $\begin{array}{l}\text { Forecast } 2 \\
\text { (Palmdale) }\end{array}$ \\
\hline \multicolumn{5}{|c|}{ Base year 1980} \\
\hline - 99.99 & 59 & 4 & 235 & 94 \\
\hline $100.00-149.99$ & 69 & 16 & 273 & 303 \\
\hline $150.00-199.99$ & 137 & 42 & 538 & 505 \\
\hline $200.00-249.99$ & 227 & 74 & 894 & 1,334 \\
\hline $250.00-299.99$ & 189 & 41 & 742 & 742 \\
\hline $300.00-340.99$ & 314 & 54 & 1,232 & 973 \\
\hline $350.00-399.99$ & 304 & 105 & 1,192 & 1,880 \\
\hline $400.00-499.99$ & 1,330 & 414 & 5,216 & 7,329 \\
\hline $500.00-599.99$ & 2,973 & 834 & 11,645 & 13,403 \\
\hline $600.00-799.99$ & 5,249 & 1,164 & 20,553 & 13,404 \\
\hline $800.00-999.99$ & 2,089 & 277 & 8,179 & 13,454 \\
\hline $1,000.00-1,499.99$ & 1,202 & 106 & 4,707 & 1,903 \\
\hline $1,500.00-1,999.99$ & 190 & 36 & 696 & 511 \\
\hline $2,000.00-4,000.00$ & 62 & 19 & 245 & 511 \\
\hline Total $\ldots .$. & 14,394 & 3,186 & 56,347 & 56,346 \\
\hline Persons per household & 2.4 & 2.44 & 2.79 & 2.79 \\
\hline \multicolumn{5}{|c|}{ Forecast years 1984, 1987, 1990, 2000, and 2010} \\
\hline 1984 total & 15,950 & 4,147 & & \\
\hline 1987 total & 20,337 & 8,043 & & \\
\hline 1990 total & 23,882 & 16,760 & & \\
\hline 2000 total & 34,216 & 36,329 & & \\
\hline 2010 total & 47,845 & 51,666 & & \\
\hline
\end{tabular}

County, California. This system has a great deal of potential for application at Edwards Air Force Base in the Antelope Valley. When this system is implemented for Edwards Air Force Base, IWRAPS is expected to improve and enhance the overall water-demand forecast for the Antelope Valley. 
Table 16. Housing statistics for multifamily housing in the Antelope Valley

Sources of data:

Housing by value ranges: U.S. Department of Commerce $(1980,1990)$.

Total multifamily housing:

Lancaster and Palmdale: Javier Minjares, Southern California Association of Governments (written commun., 1993). Antelope Valley: Alfred Gobar and Associates (1993).

Persons per household:

Lancaster and Palmdale: Persons per renter occupied total, U.S. Department of Commerce (1980).

Antelope Valley: Alfred Gobar and Associates (1993).

Forecast year projections:

Lancaster and Palmdale: Javier Minjares, Southern California Association of Governments (written commun., 1993).

\begin{tabular}{|c|c|c|c|c|c|}
\hline \multirow{3}{*}{\multicolumn{2}{|c|}{$\begin{array}{l}\text { Value range } \\
\text { (in } \$ 100^{\prime} s \text { ) }\end{array}$}} & \multicolumn{4}{|c|}{ Number of houses in each value range } \\
\hline & & \multirow[b]{2}{*}{ Lancaster } & \multirow[b]{2}{*}{ Palmdale } & \multicolumn{2}{|c|}{ Antelope Valley } \\
\hline & & & & $\begin{array}{l}\text { Forecast } 1 \\
\text { (Lancaster) }\end{array}$ & $\begin{array}{l}\text { Forecast } 2 \\
\text { (Palmdale) }\end{array}$ \\
\hline \multicolumn{6}{|c|}{ Base year 1980} \\
\hline 0 & 119.99 & 68 & 64 & 266 & 493 \\
\hline 120.00 & 148.49 & 93 & 62 & 363 & 482 \\
\hline 148.50 & 223.49 & 199 & 78 & 776 & 611 \\
\hline 223.50 & 298.48 & 269 & 119 & 1,051 & 927 \\
\hline 298.49 & 373.48 & 449 & 213 & 1,753 & 1,654 \\
\hline 373.49 & 448.47 & .431 & 286 & 1,677 & 2,227 \\
\hline 448.48 & 523.47 & 428 & 269 & 1,671 & 2,087 \\
\hline 523.48 & 598.46 & 340 & 203 & 1,326 & 1,584 \\
\hline 598.47 & 700.00 & 640 & 169 & 2,495 & 1,313 \\
\hline Total & & 2,917 & 1,463 & 11,378 & 11,378 \\
\hline Persons & household & 4.1 & 2.03 & 2.79 & 2.79 \\
\hline \multicolumn{6}{|c|}{ Forecast years $1984,1987,1990,2000$, and 2010} \\
\hline 1984 to & & 3,740 & 2,352 & & \\
\hline 1987 to & & 4,823 & 4,189 & & \\
\hline 1990 to & & 9,017 & 5,191 & & \\
\hline 2000 to & & 14,505 & 11,534 & & \\
\hline 2010 to & & 22,422 & 18,807 & & \\
\hline
\end{tabular}


Table 17. Antelope Valley population projections as reported by various agencies

$[-$, no data available $]$

Sources of data:

AGA, Alfred Gobar and Associates (1993).

AV PSA, California Department of Water Resources (1980; 1993b) projections for the Antelope Valley Planning Subarea.

C, U.S. Department of Commerce $(1960 ; 1970 ; 1980 ; 1990)$.

DF, California Department of Finance (1992).

DWR, Marla Hambright, California Department of Water Resources (written commun., 1993).

EDC, Vern Lawson, Lancaster Economic Development Corporation (written commun., 1993).

KC, Kern County.

KCG, Kern County Council of Governments (1990).

LAC, Ramon Gonzales, Los Angeles County Department of Public Works (written commun., 1993).

SCAG, Southern California Association of Governments (1993).

\begin{tabular}{|c|c|c|c|c|c|c|c|c|}
\hline \multirow{2}{*}{ Year } & \multirow{2}{*}{ Source } & \multirow{2}{*}{ Lancaster } & \multirow{2}{*}{ Palmdale } & \multirow{2}{*}{$\begin{array}{c}\text { Antelope } \\
\text { Valley, } \\
\text { Kern } \\
\text { County } \\
\text { only }\end{array}$} & \multirow{2}{*}{$\begin{array}{c}\text { Antelope } \\
\text { Valley } \\
\text { total }\end{array}$} & \multirow{2}{*}{$\begin{array}{l}\text { Antelope } \\
\text { Valley } \\
\text { "Planning } \\
\text { Subarea" }\end{array}$} & \multicolumn{2}{|c|}{$\begin{array}{c}\text { Antelope Valley } \\
\text { "Detailed Analyses Units" }\end{array}$} \\
\hline & & & & & & & $\begin{array}{l}\text { Los Angeles } \\
\text { County }\end{array}$ & $\begin{array}{c}\text { Kern } \\
\text { County }\end{array}$ \\
\hline$\overline{1950}$ & EDC & 10,250 & - & $\overline{--}$ & 16,084 & - & $\overline{-}$ & \\
\hline 1960 & DWR & 26,012 & 11,522 & -- & -- & 79,640 & 62,620 & 17,020 \\
\hline 1960 & $\mathrm{C}$ & 26,012 & & .- & .- & 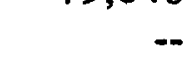 & -. & -- \\
\hline 1960 & EDC & 26,012 & 7,121 & -- & 68,170 & -. & -- & -- \\
\hline 1970 & $\mathrm{C}$ & 30,948 & - & -- & - & -- & -- & - \\
\hline 1970 & $\mathrm{DWR}^{1}$ & 38,582 & 8,511 & .- & .- & -- & .. & \\
\hline 1970 & DWR & 30,948 & 8,511 & -- & -- & 97,832 & 77,452 & 20,380 \\
\hline 1970 & EDC & 30,948 & & -- & 82,771 & - & - & -- \\
\hline 1970 & LAC & - & 8,511 & -- & - & -- & -- & -- \\
\hline 1972 & $\mathrm{DWR}^{1}$ & - & -- & - & -- & 99,100 & -- & -- \\
\hline 1975 & DWR & -- & -- & -- & 95,000 & -- & -. & \\
\hline 1975 & LAC & -- & 9,736 & -- & - & - & $\cdots$ & -- \\
\hline 1980 & C & 48,027 & 12,277 & -- & $\ldots$ & -. & -. & -. \\
\hline 1980 & $\mathrm{DF}$ & 48,027 & 12,277 & -- & -. & .- & -. & .. \\
\hline 1980 & DWR & 48,027 & 12,277 & -- & -- & ${ }^{2} 124,350$ & 103,200 & 21,150 \\
\hline 1980 & EDC & 48,027 & & -- & 111,294 & -- & -- & -- \\
\hline 1980 & $\mathrm{AGA}$ & 48,027 & 12,277 & -- & 122,879 & -- & -- & -- \\
\hline 1980 & SCAG & ${ }^{2} 48,103$ & ${ }^{2} 12,287$ & -- & - & -- & -- & -- \\
\hline 1980 & KCG & & & 12,124 & -- & - & -- & -- \\
\hline 1981 & $\mathrm{DF}$ & 50,065 & 13,629 & - & - & - & -- & - \\
\hline 1982 & $\mathrm{DF}$ & 52,646 & 15,515 & -- & -- & -- & -- & -- \\
\hline 1983 & $\mathrm{DF}$ & 54,859 & 17,368 & -- & -- & -- & -- & -- \\
\hline 1984 & $\mathrm{DF}$ & 57,852 & 19,911 & -- & -- & -- & -- & -- \\
\hline 1984 & SCAG & ${ }^{2} 53,827$ & ${ }^{2} 17,711$ & -- & -- & -- & -- & -- \\
\hline 1985 & $\mathrm{DF}$ & 60,866 & 23,593 & -- & -- & -- & -- & - \\
\hline 1986 & DF & 65,840 & 27,440 & -- & -- & -- & -. & -- \\
\hline 1987 & $\mathrm{DF}$ & 74,091 & 37,873 & -- & -- & -- & -. & -- \\
\hline 1987 & DWR $^{1}$ & 68,000 & 33,000 & & & 149,510 & & \\
\hline 1987 & SCAG & ${ }^{2} 68,063$ & ${ }^{2} 33,103$ & -- & -- & -- & -- & -- \\
\hline 1988 & $\mathrm{DF}$ & 81,135 & 44,494 & -- & -- & .- & - & -- \\
\hline
\end{tabular}

Footnotes at end of table. 
Table 17. Antelope Valley population projections as reported by various agencies--Continued

\begin{tabular}{|c|c|c|c|c|c|c|c|c|}
\hline \multirow{2}{*}{ Year } & \multirow{2}{*}{ Source } & \multirow{2}{*}{ Lancaster } & \multirow{2}{*}{ Palmdale } & \multirow{2}{*}{$\begin{array}{c}\text { Antelope } \\
\text { Valley, } \\
\text { Kern } \\
\text { County } \\
\text { only } \\
\end{array}$} & \multirow{2}{*}{$\begin{array}{l}\text { Antelope } \\
\text { Valley } \\
\text { total }\end{array}$} & \multirow{2}{*}{$\begin{array}{l}\text { Antelope } \\
\text { Valley } \\
\text { "Planning } \\
\text { Subarea" }\end{array}$} & \multicolumn{2}{|c|}{$\begin{array}{c}\text { Antelope Valley } \\
\text { "Detailed Analyses Units" }\end{array}$} \\
\hline & & & & & & & $\begin{array}{l}\text { Los Angeles } \\
\text { County }\end{array}$ & $\begin{array}{l}\text { Kern } \\
\text { County }\end{array}$ \\
\hline 1989 & $\overline{D F}$ & 89,216 & 51,730 & - & - & -- & -- & -- \\
\hline 1989 & EDC & 82,182 & 45,859 & -- & -- & 224,230 & -- & -- \\
\hline 1990 & DF & 97,291 & 68,842 & 24,035 & -- & -- & -- & -- \\
\hline 1990 & DWR & 97,291 & 54,720 & -- & -- & ${ }^{2} 260,400$ & 234,100 & 26,300 \\
\hline 1990 & EDC & 88,700 & 56,500 & -- & 250,510 & -- & -- & -- \\
\hline 1990 & AGA & 97,291 & 68,389 & -- & 273,443 & -- & -- & -- \\
\hline 1990 & SCAG & ${ }^{2} 97,291$ & ${ }^{2} 68,842$ & -- & -- & -- & -- & -- \\
\hline 1990 & $\mathrm{KCG}$ & -- & -- & 23,806 & -- & -- & -- & -- \\
\hline 1991 & EDC & 102,026 & -- & -- & 270,000 & -- & -- & -- \\
\hline 1992 & EDC & 104,700 & - & -- & 282,500 & -- & -- & - \\
\hline 1993 & AGA & 140,412 & 110,590 & 35,363 & 309,528 & -- & -- & -. \\
\hline 1995 & EDC & 120,000 & -- & - & 314,500 & -- & -- & -- \\
\hline 1995 & KCG & -- & -- & 29,640 & -- & -- & -- & -- \\
\hline 1998 & AGA & 165,472 & 138,132 & 38,553 & 369,913 & -- & -- & -- \\
\hline 2000 & DF & -- & - & 53,008 & -- & -- & -- & -- \\
\hline 2000 & KCG & -- & -- & 36,650 & -- & -- & - & -. \\
\hline 2000 & DWR & -- & - & -- & -- & ${ }^{2} 504,600$ & 465,000 & 39,600 \\
\hline 2000 & $\mathrm{DWR}^{3}$ & -. & -- & -- & 499,000 & -- & -. & -- \\
\hline 2000 & SCAG & ${ }^{2} 152,279$ & ${ }^{2} 161,200$ & -- & -- & -- & -- & -- \\
\hline 2005 & $\mathrm{KCG}$ & -- & - & 45,268 & -- & -- & -- & -- \\
\hline 2010 & DF & -- & -- & -- & 690,000 & -- & -- & -- \\
\hline 2010 & DWR & -- & -- & -- & -- & ${ }^{2} 690,000$ & 633,800 & 56,200 \\
\hline 2010 & $\mathrm{DWR}^{3}$ & -- & - & -- & 738,000 & -- & -- & -- \\
\hline 2010 & KCG & -- & -- & 53,132 & -- & -- & -- & -- \\
\hline 2010 & SCAG & ${ }^{2} 212,140$ & ${ }^{2} 226,425$ & - & -- & -- & -- & -- \\
\hline 2015 & KCG & -- & -- & 64,866 & - & -- & -- & -- \\
\hline 2020 & $\mathrm{DF}$ & -- & - & -- & 812,000 & -- & -- & -- \\
\hline 2020 & DWR & -- & -- & -- & -- & 811,900 & 744,700 & 76,200 \\
\hline 2020 & $\mathrm{DWR}^{3}$ & -- & -- & -- & 986,000 & - & -- & -- \\
\hline 2020 & KCG & -- & -- & 73,296 & -- & -- & -- & -- \\
\hline
\end{tabular}

${ }^{1}$ California Department of Water Resources (1990b, p. 13).

${ }^{2}$ Data used in the MWD_MAIN model.

${ }^{3}$ California Department of Water Resources (1993a, p. 250).

\section{DATA-BASE DEVELOPMENT AND ANNUAL UPDATE PROCEDURE}

The data base for this study was compiled using ARC/INFO, a geographic information system, and Quatro Pro, a spreadsheet software. Site-specific and aggregated water-supply, land-use, socioeconomic, and demographic data make up the data base.

Data from various water agencies were obtained in computer-readable format or were entered manually if computer-readable versions were not available or were incompatible with software used for this study. Computerized dara were available from Antelope Valley-East Kern Water Agency, California State Water Resources Control Board, Metropolitan Water District of Southern California, Palmdale Water District, and the Southern California Association of Governments.

An annual update procedure could include contacting each water supplier, as well as the State Water Resources Control Board, for the most recent 
data for a calendar year. Annual updates to this data base would be greatly facilitated if each of the agencies supplying water in the valley used a common format for data storage or stored the same basic information in their data systems. A more formal agreement could be established with each water supplier and major water user to supply their annual updates as they become available. An annual review of the list of water suppliers and users would be needed to improve confidence in the adequacy of the data, and users might need to be added or removed each year.

\section{WATER-RESOURCES MANAGEMENT CONSIDERATIONS}

Demands on available water supplies for the Antelope Valley were reported to be 127,361 acre- $\mathrm{ft}$ in 1991 and, on the basis of recent forecasts, are projected to be between 127,000 and about 329,000 (tables 2 and 12) acre-ft by 2010. In 1991, reported water demands in the valley totaled about 127,361 acre-ft: 91,743 acre-ft came from ground-water supplies; 27,396 acre-ft came from imported surface-water supplies; 1,669 acre-ft came from local surface-water supplies; and 6,553 acre-ft came from reclaimed wastewater supplies (table 2). Imported water from the State Water Project normally would have been a larger percentage of the total supply, but the availability of that water was severely affected by the 1987-92 drought. Additional ground water was used to meet the demand.

The ground-water system in the Antelope Valley is a naturally stable, long-term, but finite source of water. Average ground-water recharge is estimated to be about 40,000 to 58,000 acre-ft/yr (Snyder, 1955; Bloyd, 1967; Durbin, 1978). When ground-water use exceeds replenishment, water levels decline and the source becomes depleted. Ground water in the Antelope Valley was depleted extensively during the peak agricultural period of the 1950's. Ground-water depletion in recent years can be estimated on the basis of ground-water pumpage data presented in figure 10 (assuming the true value for 1988 is the average of 1987 and 1989). Assuming that recharge averaged 40,000 to 58,000 acre- $\mathrm{ft} / \mathrm{yr}$, the average rate of ground-water depletion from 1983 to 1991 would have been about 8,000 to 26,000 acre-ft/yr. Recharge may have been less than the annual long-term average during that period because of below average precipitation (fig. 2) and related surface runoff during the drought. Ground-water depletion during 1983-91, therefore, could have been greater than that estimated above.

Adverse consequences of ground-water-level declines include increased pumping lifts, reduced well efficiency, and the potential for aquifer-system compaction and associated land subsidence that can result in damage to public infrastructures. The economic effects of increased pumping lifts and reduced well efficiency include increased power requirements to pump the same volume of water and the eventual need for deeper wells as water levels approach the bottom of existing screened intervals. Economic and environmental effects of aquifer-system compaction and associated land subsidence in the Antelope Valley include fissures, sinkholes, broken well casings, decreased hydraulic head in the aquifer system, and unstable vertical datum, which is used for constructing drainage and flood-control structures. Additional potential effects caused by subsidence include insurance and legal implications, flood-control problems, and damage to structures, transportation facilities, and agricultural land. Maximum measured land subsidence was $6.0 \mathrm{ft}$ from 1926-92, with about $4.7 \mathrm{ft}$ occurring after 1957 (Ikehara and Phillips, 1994, table 8).

Management of water supply and water demand (including conservation of available water resources) is becoming an increasingly popular option available to water-resource managers. Recent efforts throughout the arid west have indicated that great water savings are possible when best-management practices are used. Currently (1994), no water suppliers in the Antelope Valley have adopted local best-management waterconservation practices.

Blomquist (1992) writes "Groundwater basin management represents a deliberate effort to derive greater benefits from the use of this resource while avoiding its depletion and the associated human welfare costs." A deliberate management effort is needed to meet future water demands in the Antelope Valley without incurring the economic and environmental costs associated with overuse of the ground-water resource. Part of this effort could involve the conjunctive use of surface and ground water. When available, excess local or imported surface water can be stored underground for use during periods of peak demand, such as in 1991 when imported water supplies were severely reduced. The managed, conjunctive use of surface and ground water can serve to meet demands during 
periods of drought and to mitigate land subsidence and other potential adverse effects of ground-waterstorage depletion.

Some water suppliers in the Antelope Valley have adopted a conjunctive-use practice called the "in lieu of pumping" program as documented by the California Department of Water Resources (1980). This program involves the use of imported surface water in addition to (or instead of) ground-water pumpage. The net result is less ground water pumped within the valley. Ground-water pumpage still could continue to increase but at a lower rate than if ground water were the sole water source (fig. 8).

Efficient capture, storage, and management of local surface water, imported surface water, and reclaimed wastewater would be an integral part of a conjunctive-use program in the Antelope Valley. With the exception of reclaimed wastewater, the volume of water available from these sources is highly variable-minimal during periods of drought and abundant during storms or years of above average precipitation. The ability to capture or obtain and store water from these sources when it is available is limited by economic and physical factors. These factors include the costs and feasibility of building and maintaining facilities to capture, store, and treat these water resources.

\section{SUMMARY AND CONCLUSIONS}

Land use and water use in the Antelope Valley, California, have varied significantly since development of the valley began in the late 1800's. Ground water has been a major source of water supply in this area because of limited local surfacewater resources. Completion of the California Aqueduct to this area in the early 1970's imported water from the Sacramento-San Joaquin Delta, about $400 \mathrm{mi}$ to the north. Estimates of groundwater pumpage, which previously have been published, increased from about 29,000 acre- $\mathrm{ft}$ in 1919 to about 400,000 acre-ft in the 1950 's. Declines in ground-water levels and increased costs for electrical power in the 1970's decreased the quantity of ground water pumped annually for irrigation uses. Total annual reported ground-water pumpage decreased to about 53,200 acre-ft in 1983 and increased to about 91,700 acre-ft in 1991 as a result of the 1987-92 drought. Rapid urban development, coincidental with several years of drought, renewed concerns about a possible return to extensive ground-water-storage depletion and increased land subsidence. In 1992-93, a water-use survey was done in the Antelope Valley to identify current and historical quantities of water use.

Forecasts in this report indicate that increased water demands will continue with continued urban development. These forecasts are based on projections of population growth and other socioeconomic variables provided by various agencies. Although the availability of socioeconomic data is limited and many sources of error are inherent in the forecasting process, preliminary results indicate that water demands could increase from 127,361 acre-ft in 1991 to between 127,000 and about 329,000 acre-ft by 2010. Various forecasting options are identified. The reliability of forecasting results for the Antelope Valley is controlled by the availability of input data needed for the forecasting method selected and data on actual water demands. The level of detailed information needed to make decisions on local water-resources management is expected to be made by members of the Antelope Valley Water Group and other interested parties. Potential water-resource management actions for the Antelope Valley include (1) increasing artificial ground-water recharge when excess local runoff (or imported water supplies) are available, (2) implementing water-conservation best-management practices, and (3) optimizing ground-water pumpage and conjunctive-use throughout the basin.

\section{References Cited}

Aerial Information Systems, 1992, Southern California, 1990 Aerial land use study, land use level III/IV classification "long version": Aerial Information Systems report for the Los Angeles County Department of Regional Planning, 41 p.

Alfred Gobar and Associates, 1993, Antelope Valley labor market study: Placentia, Calif., 111 p.

Anderson, J.R., Hardy, E.E., Roach, J.T., and Witmer, R.E., 1976, A land use and land cover classification system for use with remote sensor data: U.S. Geological Survey Professional Paper 964, 28 p.

Antelope Valley Board of Trade, 1993, Antelope Valley the competitive edge: A demographic and economic study of north Los Angeles and East Kern Counties: Lancaster, Calif., Antelope Valley Board of Trade, unpaginated. 
Blodgett, J.C., and Nasseri, Iraj, 1993, Selected precipitation characteristics in Antelope Valley, Mojave Desert, California, in Kuo, C.Y., ed., Engineering hydrology--Proceedings of the symposium, San Francisco, July 25-30, 1993: New York, American Society of Civil Engineers, p. 7-12.

Blomquist, W.A., 1992, Dividing the water--Governing ground water in Southern California: San Francisco, International Center for Self-Governance Press, 415 p.

Bloyd, R.M., Jr., 1967, Water resources of the Antelope Valley-East Kern Water Agency area, California: U.S. Geological Survey Open-File Report, 69 p.

California Department of Finance, 1992, California annual population and housing data April 1, 1980, to April 1, 1990, for cities, counties, and the State: California Department of Finance Report E-8090, p. 59-88.

1993, Population projections by race/ethnicity for California and its counties, 1990-2040: California Department of Finance Report 93-1, unpaginated.

California Department of Public Works, 1955, Memorandum report on water conditions in Antelope Valley: Division of Water Resources, $27 \mathrm{p}$.

California Department of Water Resources, 1958, Desert areas of southeastern California land and water use survey, 1958: California Department of Water Resources Bulletin 101, 74 p.

1965, Southern Lahontan area land and water use survey, 1961: California Department of Water Resources Bulletin 121, 77 p.

1974, Desert area land and water use survey, 1972:

Southern District Report, 22 p.

1977, The California State Water Project-1976

Activities and future management plans: California Department of Water Resources Bulletin 132-77, 207 p.

1980, Planned utilization of water resources in Antelope Valley: Southern District, $70 \mathrm{p}$.

1983, The California water plan, projected use and available water supplies to 2010: California Department of Water Resources Bulletin 160-83, 268 p.

1985, Management of the California State Water

Project: California Department of Water Resources

Bulletin 132-85, 269 p.

1987, California Water, looking to the future:

California Department of Water Resources Bulletin

160-87, $122 \mathrm{p}$.

1988, Memorandum report--Additional information

for Bulletin 160-87: $85 \mathrm{p}$.

1990a, 1988 Annual water use--Water supply

balances: Memorandum Report, 59 p.

1990b, South Lahontan and northern Colorado

Desert land use survey, 1987: Southern District, $49 \mathrm{p}$.

1991a, Management of the California State Water

Project: California Department of Water Resources

Bulletin 132-91, 320 p.
California Department of Water Resources, 1991b, 1989 Annual water use--Water supply balances:

Memorandum Report, 28 p.

1993a, California water plan update: California

Department of Water Resources Bulletin 160-93

(draft), v. 1, 401 p., v. 2, 347 p.

1993b, Diskette containing demographic

information for the State of California: Sacramento,

Calif. (Diskette available from Marla Hambright,

California Department of Water Resources, 1416

Ninth Street, Sacramento, California 95814).

California State Water Resources Control Board, 1977,

Regulations and information pertaining to

appropriations of water in California: In

Administrative Code, Title 23, Waters, chap. 3: State

Water Resources Control Board, Subchapter 1,

General Provisions; Subchapter 2, Appropriation of Water, 74 p.

Cameron, T.A., Coffin, Lisa, and Mandapati, Bharati, 1993, User's guide, BMP water savings simulation program, version 2.2: Los Angeles, University of California, 58 p., 3 appendices.

City of Lancaster, 1993, Demographic information: Lancaster, Calif., Department of Community Development.

Davis, W.Y., Rodrigo, D.M., Opitz, E.M., Dziegielewski, Benedyct, and Boland, J.J., 1991, IWR_MAIN water use forecasting system, Version 5.1--User's manual and system description: U.S. Army Corps of Engineers, Institute for Water Resources, IWR Report 88-R-6.

Duell, L.F.W., Jr., 1987, Geohydrology of the Antelope Valley area, California, and design for a ground-water-quality monitoring network: U.S. Geological Survey Water-Resources Investigations Report 84-4081, 72 p.

Durbin, T.J., 1978, Calibration of a mathematical model of the Antelope Valley ground-water basin, California: U.S. Geological Survey Water-Supply Paper 2046, $51 \mathrm{p}$.

Ewing, P.A., 1945, The irrigation development of Antelope Valley, California: U.S. Department of Agriculture, Soil Conservation Service, Division of Irrigation.

Holland, T.W., and Baker, N.T., 1993, Evaluation of pumpage data furnished by selected public water suppliers in Arkansas, May 1990 through March 1991: U.S. Geological Survey Water-Resources Investigations Report 93-4104, $80 \mathrm{p}$.

Ikehara, M.E., and Phillips, S.P., 1994, Determination of land subsidence related to ground-water-level declines using global positioning system and leveling surveys in Antelope Valley, Los Angeles, and Kern Counties, California, 1992: U.S. Geological Survey Water-Resources Investigations Report 94-4184, 101 p.

Johnson, H.R., 1911, Water resources of Antelope Valley, California: U.S. Geological Survey Water-Supply Paper 278, 92 p. 
Kenny, J.F., 1986, Water demands in Kansas, 1944-84: U.S. Geological Survey Water-Resources Investigations Report 86-4038, $17 \mathrm{p}$.

Kern County Council of Governments, 1990, Computer file, Traffic analysis zones: Bakersfield, Calif. [Computer report available from Kern County Council of Governments, Bakersfield, CA 93301].

1991, Employees by Zip/SIC code for Antelope Valley in East Kern: Bakersfield, Calif., p. 1-6.

Law Environmental, 1991, Water supply evaluation, Antelope Valley, California: Palmdale Water District, 49 p., 4 appendices.

Los Angeles County Department of Public Works, 1991, Report on Lancaster Coalition of Neighborhood Organizations concerns with the Antelope Valley water supply: Michael D. Antonovich, Los Angeles County Board of Supervisors, $15 \mathrm{p}$.

Mann, J.F., Jr., 1989, Status report on the ground water resources near the Palmdale Regional Airport: Consultants report prepared for and in the files of the Los Angeles County, Department of Public Works, $36 \mathrm{p}$.

Metropolitan Water District of Southern California, 1993, Magnetic tape files containing water use information for the Metropolitan Water District's service area: [Computer tape available from Metropolitan Water District of Southern California, Los Angeles CA 90012].

National Oceanic and Atmospheric Administration, 1991, Station history listing, accumulation of 16 years of climatic data from 1974-1990, for Palmdale Flight Service Station, Lancaster State Highway, and Mojave, Temperature data 1974-1987, Rainfall data 1980-1990, Cooling degree data 1974-87: Asheville, N.C. [Computer tape available from U.S.

Department of Commerce, National Climatic Data Center, Asheville, NC 28801-2696].

Rantz, S.E., 1969, Mean annual precipitation in the California region: U.S. Geological Survey Open-File Report, 2 sheets, scale 1:1,000,000.

Snyder, J.H., 1955, Ground water in California, the experience of Antelope Valley: University of California Berkeley, Giannini Foundation Ground Water Studies No. 2, $156 \mathrm{p}$.

Southern California Association of Governments, 1993, Magnetic tape containing socioeconomic data of Southern California Association of Governments members: Los Angeles, Calif. [Computer tape available from Southern California Association of Governments, Los Angeles, CA 90017].
Suzuki, H.E., 1987, Feasibility report for proposed domestic water system improvements, additional sources of water supply, distribution and supply means, additions and replacements, water storage facilities: Application for loan from California Department of Water Resources, under the DavisGrounsky Act.

Templin, W.E., and Schluter, R.C., 1990, A waterresources data-network evaluation for Monterey County, California. Phase 3. Northern Salinas River Drainage basin: U.S. Geological Survey WaterResources Investigations Report 89-4123, 96 p.

Thompson, J.G., Parker, Michael, Templin, W.E., and Reynolds, R.R., Jr., 1993, A review of applications issues of the Metropolitan Water District-MAIN water forecasting systems: Water Resources Bulletin, v. 29 , no. 3, p. $425-433$.

U.S. Department of Commerce, 1960, Census of population and housing: Washington, D.C., Bureau of the Census, p. 27.

1970, Census of population and housing:

Washington, D.C., Bureau of the Census, Table P1, p. 3, Table P3, p. 273.

1980, Census of population and housing:

Washington, D.C., Bureau of the Census, Table P1, p. $235,824,897,898,957,958$; Table P10, p. 785 ;

Table H1, p. 43, 44, 116, 117, 157, 158.

1990 , Census of population and housing.

Summary tape files 1 and 3, magnetic tape and compact disk containing U.S. Census socioeconomic data: Washington, D.C., Bureau of the Census. [Computer tape and compact disk available from the U.S. Department of Commerce, Bureau of the Census, Washington, D.C. 20233].

U.S. Geological Survey, 1990, National Water Summary 1987--Hydrologic events and water supply use: U.S. Geological Survey Water-Supply Paper 2350, 553 p.

Weston, R.F., Inc., 1986, Water supply availability and distribution system evaluation, Edwards Air Force Base, California: Prepared for Edwards Air Force Base, Air Force Systems Command, Andrews Air Force Base, D.C.

1988, Work Plan--Water supply availability and distribution system evaluation, rocket site, Edwards Air Force Base, California: Prepared for Edwards Air Force Base, Air Force Systems Command, Andrews Air Force Base, D.C., various pagination. 
Table 18. Water-use information for public water suppliers in Antelope Valley by water-supply sources, $1946-92$

[Units are in acre-feet. Note: Purchased water may not agree with imported water because it may include purchases from other water suppliers within the Antelope Valley. All values may not add to totals because of independent rounding. --, no data available]

\begin{tabular}{|c|c|c|c|c|c|c|c|c|c|}
\hline \multirow{2}{*}{ Year } & \multirow{2}{*}{$\begin{array}{l}\text { Antelope Valley } \\
\text { High School } \\
\text { District } \\
\text { Ground water }\end{array}$} & \multicolumn{3}{|c|}{$\begin{array}{l}\text { Antelope Valley } \\
\text { Water Company }\end{array}$} & \multirow{2}{*}{$\begin{array}{c}\begin{array}{c}\text { Averydale } \\
\text { Municipal } \\
\text { Water Company }\end{array} \\
\text { Ground water }\end{array}$} & \multicolumn{3}{|c|}{$\begin{array}{l}\text { Boron Community } \\
\text { Service District }\end{array}$} & \multirow{2}{*}{$\begin{array}{c}\begin{array}{c}\text { Briarwood } \\
\text { Mobile } \\
\text { Home Park }\end{array} \\
\begin{array}{c}\text { Ground } \\
\text { water }\end{array}\end{array}$} \\
\hline & & $\begin{array}{l}\text { Ground } \\
\text { water }\end{array}$ & Purchased & 1 Total & & $\begin{array}{c}\text { Ground } \\
\text { water }\end{array}$ & Purchased & Total & \\
\hline$\overline{1946}$ & 0 & $\overline{0}$ & -- & $\overline{0}$ & 0 & 0 & .. & $\overline{0}$ & 0 \\
\hline 1947 & 100.0 & 0 & -- & 0 & 0 & 0 & -- & 0 & 0 \\
\hline 1948 & 411.0 & 26.0 & -- & 26.0 & 0 & 0 & -- & 0 & 0 \\
\hline 1949 & 123.0 & 27.0 & -- & 27.0 & 0 & 0 & -- & 0 & 0 \\
\hline 1950 & 124.0 & 28.0 & -- & 28.0 & 0 & 0 & -- & 0 & 0 \\
\hline 1951 & 132.0 & 162.0 & -- & 162.0 & 0 & 0 & -- & 0 & 0 \\
\hline 1952 & 140.0 & $1,161.0$ & -- & $1,161.0$ & 0 & 0 & -- & 0 & 0 \\
\hline 1953 & 61.0 & 772.0 & -- & 772.0 & 0 & 0 & -- & 0 & 0 \\
\hline 1954 & 9.0 & 244.0 & -- & 244.0 & 0 & 0 & -- & 0 & 0 \\
\hline 1955 & 165.0 & 134.0 & -- & 134.0 & 0 & 0 & -- & 0 & 0 \\
\hline 1956 & 45.0 & 808.0 & -- & 808.0 & 0 & 0 & -- & 0 & 0 \\
\hline 1957 & 261.0 & 523.0 & -- & 523.0 & 0 & 0 & -- & 0 & 0 \\
\hline 1958 & 11.0 & 62.0 & -- & 62.0 & 0 & 0 & -- & 0 & 0 \\
\hline 1959 & 347.0 & 336.0 & -- & 336.0 & 0 & 0 & -- & 0 & 0 \\
\hline 1960 & 0 & 76.0 & -- & 76.0 & 0 & 0 & -- & 0 & 0 \\
\hline 1961 & 155.0 & $1,017.0$ & -- & $1,017.0$ & 0 & 0 & -- & 0 & 0 \\
\hline 1962 & 92.0 & 509.0 & .- & 509.0 & 0 & 0 & -- & 0 & 0 \\
\hline 1963 & 157.0 & 99.0 & -- & 99.0 & 500.0 & 0 & -- & 0 & 0 \\
\hline 1964 & 20.0 & 316.0 & -- & 316.0 & 0 & 298.0 & -- & 298.0 & 0 \\
\hline 1965 & 219.0 & 108.0 & -- & 108.0 & 191.0 & 305.0 & -- & 305.0 & 0 \\
\hline 1966 & 568.0 & $1,149.0$ & -- & $1,149.0$ & 225.0 & 347.0 & -- & 347.0 & 0 \\
\hline 1967 & $1,602.0$ & 90.0 & -- & 90.0 & 551.0 & 347.0 & .. & 347.0 & 0 \\
\hline 1968 & 364.0 & 109.0 & -- & 109.0 & 247.0 & 472.0 & .- & 472.0 & 0 \\
\hline 1969 & $1,033.0$ & 338.0 & -- & 338.0 & 464.0 & 451.0 & .. & 451.0 & 0 \\
\hline 1970 & 500.0 & 242.0 & -. & 242.0 & 0 & 509.0 & .- & 509.0 & 0 \\
\hline 1971 & 420.0 & 346.0 & .- & 346.0 & 263.0 & 606.0 & .- & 606.0 & 0 \\
\hline 1972 & 422.0 & 625.0 & -- & 625.0 & 620.0 & 621.0 & -- & 621.0 & 0 \\
\hline 1973 & $1,888.0$ & 268.0 & -- & 268.0 & 236.0 & 592.0 & .. & 592.0 & 0 \\
\hline 1974 & 378.0 & 329.0 & -- & 329.0 & 243.0 & 620.0 & -- & 620.0 & 0 \\
\hline 1975 & 440.0 & 370.0 & -- & 370.0 & 204.0 & 630.0 & .- & 630.0 & 0 \\
\hline 1976 & 395.0 & 378.0 & 0 & 378.0 & 243.0 & 565.0 & 0 & 565.0 & 0 \\
\hline 1977 & 383.0 & 343.0 & 0 & 343.0 & 238.0 & 572.0 & 0 & 572.0 & 0 \\
\hline 1978 & 336.0 & 202.0 & 90.0 & 292.0 & 24.0 & 605.0 & 0 & 605.0 & 0 \\
\hline 1979 & 303.0 & 382.0 & 119.0 & 501.0 & 276.0 & 549.0 & 0 & 549.0 & 0 \\
\hline 1980 & 427.0 & 439.7 & 80.0 & 519.7 & 461.2 & 580.0 & 116.0 & 696.0 & 0 \\
\hline 1981 & 305.0 & 498.2 & 43.0 & 541.2 & 577.6 & 498.0 & 190.0 & 688.0 & 0 \\
\hline 1982 & 220.0 & 470.4 & 29.0 & 499.4 & 252.2 & 290.0 & 239.0 & 529.0 & 0 \\
\hline 1983 & 297.0 & 323.2 & 41.0 & 364.2 & 238.2 & 286.0 & 283.0 & 569.0 & 0 \\
\hline 1984 & 209.0 & 558.2 & 54.0 & 612.2 & 0 & 238.0 & 268.0 & 506.0 & 0 \\
\hline 1985 & 161.0 & 578.3 & 70.0 & 648.3 & 295.4 & 327.0 & 368.0 & 695.0 & 0 \\
\hline 1986 & 200.0 & 677.1 & 119.0 & 796.1 & 300.7 & 323.0 & 364.0 & 687.0 & 0 \\
\hline 1987 & 209.0 & 694.8 & 142.0 & 836.8 & 301.3 & 225.0 & 253.0 & 478.0 & 0 \\
\hline 1988 & 0 & 0 & 188.0 & 188.0 & 0 & 233.0 & 262.0 & 495.0 & 0 \\
\hline 1989 & 259.0 & $1,763.1$ & 241.0 & $2,004.1$ & 356.2 & 0 & 358.0 & 358.0 & 0 \\
\hline 1990 & 0 & 708.0 & 238.0 & 946.0 & 0 & 0 & 264.0 & 264.0 & 0 \\
\hline 1991 & 229.0 & 628.3 & 181.0 & 809.3 & 463.6 & 0 & 274.0 & 274.0 & 172.3 \\
\hline 1992 & 0 & 0 & 207.0 & 207.0 & 500.0 & 0 & 253.0 & 253.0 & 0 \\
\hline
\end{tabular}


Table 18. Water-use information for publlc water suppliers in Antelope Valley by water-supply sources, 1946-92--Continued

\begin{tabular}{|c|c|c|c|c|c|c|c|c|c|c|}
\hline \multirow{2}{*}{ Year } & \multicolumn{3}{|c|}{$\begin{array}{c}\text { California } \\
\text { Poppy Reserve }\end{array}$} & \multicolumn{3}{|c|}{$\begin{array}{l}\text { Desert Lake } \\
\text { Community } \\
\text { Services District }\end{array}$} & \multirow{2}{*}{$\begin{array}{c}\begin{array}{c}\text { Edgemont } \\
\text { Acres Mutual } \\
\text { Water Co. }\end{array} \\
\begin{array}{c}\text { Purchased } \\
\text { water }\end{array}\end{array}$} & \multirow{2}{*}{$\begin{array}{c}\text { Edwards } \\
\begin{array}{c}\text { Air Force } \\
\text { Base } \\
\text { (main base) }\end{array} \\
\begin{array}{c}\text { Ground } \\
\text { water }\end{array}\end{array}$} & \multirow{2}{*}{$\begin{array}{c}\begin{array}{c}\text { Edwards } \\
\text { Air Force } \\
\text { Base } \\
\text { (rocket site) }\end{array} \\
\begin{array}{c}\text { Ground } \\
\text { water }\end{array}\end{array}$} & \multirow{2}{*}{$\begin{array}{c}\begin{array}{c}\text { Evergreen } \\
\text { Mutual Water } \\
\text { Company }\end{array} \\
\begin{array}{c}\text { Ground } \\
\text { water }\end{array}\end{array}$} \\
\hline & $\begin{array}{l}\text { Ground } \\
\text { water }\end{array}$ & Purchased & Total & $\begin{array}{l}\text { Ground } \\
\text { water }\end{array}$ & Purchased & Total & & & & \\
\hline 1946 & 0 & -- & 0 & 0 & - & 0 & -- & 0 & 0.0 & 0 \\
\hline 1947 & 0 & -- & 0 & 0 & -- & 0 & -- & 600.0 & 0 & 240.0 \\
\hline 1948 & 0 & -- & 0 & 0 & -- & 0 & -- & 650.0 & 0 & 30.0 \\
\hline 1949 & 0 & -- & 0 & 0 & -- & 0 & $\therefore$ & 650.0 & 0 & 240.0 \\
\hline 1950 & 0 & -- & 0 & 0 & -- & 0 & -- & 650.0 & 0 & 240.0 \\
\hline 1951 & 0 & -- & 0 & 0 & -- & 0 & -- & 800.0 & 0 & 240.0 \\
\hline 1952 & 0 & -- & 0 & 0 & -- & 0 & -- & $1,000.0$ & 0 & 240.0 \\
\hline 1953 & 0 & -- & 0 & 0 & -- & 0 & -- & $1,800.0$ & 0 & 150.0 \\
\hline 1954 & 0 & -- & 0 & 0 & -- & 0 & -- & $1,950.0$ & 0 & 240.0 \\
\hline 1955 & 0 & -. & 0 & 0 & -- & 0 & -- & $2,200.0$ & 0 & 200.0 \\
\hline 1956 & 0 & -- & 0 & 0 & -- & 0 & -- & $2,450.0$ & 0 & 500.0 \\
\hline 1957 & 0 & - & 0 & 0 & -- & 0 & -- & $2,700.0$ & 0 & 200.0 \\
\hline 1958 & 0 & -- & 0 & 160.0 & -- & 160.0 & -- & $3,400.0$ & 0 & 4.0 \\
\hline 1959 & 0 & -- & 0 & 140.0 & -- & 140.0 & -- & $3,750.0$ & 100.0 & 0 \\
\hline 1960 & 0 & -- & 0 & 174.0 & -- & 174.0 & -- & $3,550.0$ & 800.0 & 0 \\
\hline 1961 & 0 & -- & 0 & 180.0 & -- & 180.0 & -- & $3,750.0$ & 950.0 & 203.0 \\
\hline 1962 & 0 & -- & 0 & 180.0 & -- & 180.0 & -- & $3,950.0$ & 900.0 & 0 \\
\hline 1963 & 0 & -- & 0 & 180.0 & - & 180.0 & -- & $4,100.0$ & 900.0 & 0 \\
\hline 1964 & 0 & -- & 0 & 180.0 & -- & 180.0 & -- & $4,900.0$ & $1,600.0$ & 0 \\
\hline 1965 & 0 & -- & 0 & 290.0 & -- & 290.0 & -- & $4,950.0$ & $1,750.0$ & 57.0 \\
\hline 1966 & 0 & -- & 0 & 300.0 & -- & 300.0 & -- & $4,725.0$ & $1,500.0$ & 500.0 \\
\hline 1967 & 0 & -- & 0 & 300.0 & -- & 300.0 & -- & $4,900.0$ & $1,100.0$ & 234.0 \\
\hline 1968 & 0 & -- & 0 & 367.0 & -- & 367.0 & -- & 0 & 0 & 57.0 \\
\hline 1969 & 0 & -- & 0 & 275.0 & -- & 275.0 & -- & 0 & 0 & 322.0 \\
\hline 1970 & 0 & - & 0 & 194.0 & - & 194.0 & -- & 0 & 0 & 60.0 \\
\hline 1971 & 0 & -- & 0 & 305.0 & -- & 305.0 & -- & 0 & 0 & 75.0 \\
\hline 1972 & 0 & -- & 0 & 300.0 & -- & 300.0 & -- & 0 & 0 & $1,000.0$ \\
\hline 1973 & 0 & -- & 0 & 329.0 & -- & 329.0 & -- & 0 & 0 & 65.0 \\
\hline 1974 & 0 & -- & 0 & 331.0 & -- & 331.0 & -- & 0 & 0 & 75.0 \\
\hline 1975 & 0 & -- & 0 & 335.0 & -- & 335.0 & -- & 0 & 0 & 75.0 \\
\hline 1976 & 0 & 0 & 0 & 318.0 & 0 & 318.0 & 0 & $6,300.0$ & 0 & 125.0 \\
\hline 1977 & 0 & 0 & 0 & 320.0 & 0 & 320.0 & 0 & $5,900.0$ & 0 & 125.0 \\
\hline 1978 & 0 & 0 & 0 & 322.0 & 0 & 322.0 & 0 & $6,275.0$ & 0 & 36.0 \\
\hline 1979 & 0 & 0 & 0 & 330.0 & 0 & 330.0 & 0 & 0 & 0 & 0 \\
\hline 1980 & 0 & 0 & 0 & 225.0 & 0 & 225.0 & 0 & 0 & 0 & 0 \\
\hline 1981 & 0 & 0 & 0 & 260.0 & 62.0 & 322.0 & 4.0 & $5,225.0$ & 0 & 0 \\
\hline 1982 & 0 & 0 & 0 & 270.0 & 54.0 & 324.0 & 45.0 & $4,900.0$ & 0 & 0 \\
\hline 1983 & 0 & 0 & 0 & 300.0 & 85.0 & 385.0 & 14.0 & $5,500.0$ & 0 & 32.0 \\
\hline 1984 & 0 & 0 & 0 & 180.0 & 72.0 & 252.0 & 6.0 & $5,300.0$ & 500.0 & 51.0 \\
\hline 1985 & 0 & 0 & 0 & 193.0 & 58.0 & 251.0 & 18.0 & $3,722.4$ & 0 & 53.0 \\
\hline 1986 & 0 & 12.0 & 12.0 & 213.0 & 44.0 & 257.0 & 63.0 & $5,792.9$ & 0 & 55.0 \\
\hline 1987 & 0 & 7.0 & 7.0 & 195.0 & 31.0 & 226.0 & 185.0 & $5,545.1$ & 0 & 70.0 \\
\hline 1988 & 0 & 5.0 & 5.0 & 177.0 & 82.0 & 259.0 & 79.0 & $5,643.8$ & 426.1 & 0 \\
\hline 1989 & 0 & 6.0 & 6.0 & 0 & 80.0 & 80.0 & 185.0 & $5,030.3$ & 65.5 & 70.0 \\
\hline 1990 & 0 & 7.0 & 7.0 & 0 & 30.0 & 30.0 & 111.0 & $5,330.6$ & 359.0 & 85.0 \\
\hline 1991 & .2 & 6.0 & 6.2 & 406.2 & 30.0 & 436.2 & 64.0 & $3,466.3$ & 453.3 & 70.0 \\
\hline 1992 & 0 & 16.0 & 16.0 & 0 & 24.0 & 24.0 & 70.0 & $3,144.7$ & 414.0 & 0 \\
\hline
\end{tabular}


Table 18. Water-use information for public water suppliers in Antelope Valley by water-supply sources, 1946-92--Continued

\begin{tabular}{|c|c|c|c|c|c|c|c|c|c|c|}
\hline \multirow[t]{2}{*}{ Year } & \multicolumn{3}{|c|}{$\begin{array}{c}\text { Los Angeles } \\
\text { County Waterworks } \\
\text { District No. } 4\end{array}$} & \multicolumn{3}{|c|}{$\begin{array}{c}\text { Los Angeles } \\
\text { County Waterworks } \\
\text { District No. } 24\end{array}$} & \multirow{2}{*}{$\begin{array}{c}\text { Los Angeles } \\
\text { County Waterworks } \\
\text { District No. 27 } \\
\begin{array}{c}\text { Ground } \\
\text { water }\end{array}\end{array}$} & \multicolumn{3}{|c|}{$\begin{array}{c}\text { Los Angeles } \\
\text { County Waterworks } \\
\text { District No. } 33\end{array}$} \\
\hline & $\begin{array}{l}\text { Ground } \\
\text { water }\end{array}$ & Purchased & d Total & $\begin{array}{c}\text { Ground } \\
\text { water }\end{array}$ & Purchased & Total & & $\begin{array}{c}\text { Ground } \\
\text { water }\end{array}$ & Purchased & Total \\
\hline 1946 & 200.0 & -- & 200.0 & 0 & -- & 0 & 400.0 & 0 & - & $\overline{0}$ \\
\hline 1947 & 200.0 & -- & 200.0 & 0 & -- & 0 & 0 & 0 & -- & 0 \\
\hline 1948 & 839.0 & -- & 839.0 & 0 & -- & 0 & 200.0 & 0 & -- & 0 \\
\hline 1949 & $1,137.0$ & -- & $1,137.0$ & 0 & -- & 0 & 0 & 0 & -- & 0 \\
\hline 1950 & 585.0 & -- & 585.0 & 0 & -- & 0 & 0 & 0 & -- & 0 \\
\hline 1951 & 298.0 & -- & 298.0 & 0 & -- & 0 & 400.0 & 306.0 & -- & 306.0 \\
\hline 1952 & $1,087.0$ & -- & $1,087.0$ & 0 & -- & 0 & 0 & 0 & -- & 0 \\
\hline 1953 & $3,136.0$ & -- & $3,136.0$ & 0 & -- & 0 & 399.0 & 214.0 & -- & 214.0 \\
\hline 1954 & $1 ; 515.0$ & -- & $1,515.0$ & 455.0 & - & 455.0 & 0 & 160.0 & -- & 160.0 \\
\hline 1955 & $1,762.0$ & -- & $1,762.0$ & 0 & -- & 0 & 208.0 & 160.0 & -- & 160.0 \\
\hline 1956 & $2,463.0$ & -- & $2,463.0$ & 0 & -- & 0 & $1,017.0$ & 160.0 & -- & 160.0 \\
\hline 1957 & $4,333.0$ & -- & $4,333.0$ & 0 & -- & 0 & 782.0 & 53.0 & -- & 53.0 \\
\hline 1958 & $3,405.0$ & -- & $3,405.0$ & 0 & -- & 0 & 550.0 & 878.0 & -- & 878.0 \\
\hline 1959 & $4,157.0$ & -- & $4,157.0$ & 0 & -- & 0 & $1,320.0$ & 147.0 & -- & 147.0 \\
\hline 1960 & $5,387.0$ & -- & $5,387.0$ & 6.0 & -- & 6.0 & 194.0 & 192.0 & -- & 192.0 \\
\hline 1961 & $3,649.0$ & -- & $3,649.0$ & 884.0 & -- & 884.0 & $1,081.0$ & $4,800.0$ & -- & $4,800.0$ \\
\hline 1962 & $9,945.0$ & -- & $9,945.0$ & 819.0 & -- & 819.0 & 219.0 & 197.0 & -- & 197.0 \\
\hline 1963 & $7,760.0$ & -- & $7,760.0$ & 227.0 & -- & 227.0 & 283.0 & 125.0 & -- & 125.0 \\
\hline 1964 & $8,097.0$ & -- & $8,097.0$ & 241.0 & - & 241.0 & 246.0 & 244.0 & -- & 244.0 \\
\hline 1965 & $8,223.0$ & -- & $8,223.0$ & 145.0 & -- & 145.0 & 330.0 & 60.0 & -- & 60.0 \\
\hline 1966 & $7,979.0$ & -- & $7,979.0$ & 152.0 & - & 152.0 & 403.0 & 20.0 & -- & 20.0 \\
\hline 1967 & $8,365.0$ & - & $8,365.0$ & 948.0 & -- & 948.0 & 362.0 & 417.0 & -- & 417.0 \\
\hline 1968 & $10,750.0$ & -- & $10,750.0$ & 170.0 & -- & 170.0 & 443.0 & 0 & -- & 0 \\
\hline 1969 & $10,978.0$ & -- & $10,978.0$ & 147.0 & -- & 147.0 & 730.0 & $1,103.0$ & -- & $1,103.0$ \\
\hline 1970 & $12,572.0$ & -- & $12,572.0$ & 186.0 & -- & 186.0 & 674.0 & 0 & -- & 0 \\
\hline 1971 & $12,462.0$ & -- & $12,462.0$ & 270.0 & -- & 270.0 & 502.0 & 22.0 & -- & 22.0 \\
\hline 1972 & $13,206.0$ & -- & $13,206.0$ & 117.0 & -- & 117.0 & 846.0 & 0 & -- & 0 \\
\hline 1973 & $13,890.0$ & -- & $13,890.0$ & 123.0 & -- & 123.0 & 468.0 & 0 & -- & 0 \\
\hline 1974 & $13,252.0$ & -- & $13,252.0$ & 130.0 & -- & 130.0 & 504.0 & 0 & -- & 0 \\
\hline 1975 & $12,207.0$ & -- & $12,207.0$ & 96.0 & -- & 96.0 & 453.0 & 0 & -. & 0 \\
\hline 1976 & $11,875.0$ & 0 & $11,875.0$ & 139.0 & 0 & 139.0 & 728.0 & 0 & 0 & 0 \\
\hline 1977 & $10,038.0$ & 0 & $10,038.0$ & 119.0 & 0 & 119.0 & 657.0 & 0 & 0 & 0 \\
\hline 1978 & $15,574.1$ & $4,266.0$ & $19,840.1$ & 163.0 & 0 & 163.0 & 654.0 & 0 & 0 & 0 \\
\hline 1979 & $7,535.2$ & $5,750.0$ & $13,285.2$ & 179.3 & 0 & 179.3 & 656.1 & 0 & 0 & 0 \\
\hline 1980 & $7,773.9$ & $4,732.0$ & $12,505.9$ & 109.0 & 0 & 109.0 & 726.7 & 0 & 0 & 0 \\
\hline 1981 & $8,096.0$ & $6,359.0$ & $14,455.0$ & 93.1 & 0 & 93.1 & 550.4 & 0 & 0 & 0 \\
\hline 1982 & $9,382.6$ & $4,359.0$ & $13,741.6$ & 101.3 & 0 & 101.3 & 716.8 & 0 & 66.0 & 66.0 \\
\hline 1983 & $5,972.3$ & $3,978.0$ & $9,950.3$ & 114.0 & 0 & 114.0 . & 500.9 & 0 & 193.0 & 193.0 \\
\hline 1984 & $10,346.5$ & $7,088.0$ & $17,434.5$ & 134.4 & 0 & 134.4 & 426.7 & 0 & 391.0 & 391.0 \\
\hline 1985 & $8,852.5$ & 7,959.0 & $16,811.5$ & 189.2 & 45.0 & 234.2 & 518.3 & 0 & 664.0 & 664.0 \\
\hline 1986 & $11,125.7$ & $9,709.0$ & $20,834.7$ & 164.9 & 191.0 & 355.9 & 535.0 & 0 & 656.0 & 656.0 \\
\hline 1987 & $12,199.1$ & $10,148.0$ & $22,347.1$ & 111.6 & 232.0 & 343.6 & 611.5 & 0 & 705.0 & 705.0 \\
\hline 1988 & $11,371.9$ & $12,759.0$ & $24,130.9$ & 106.1 & 360.0 & 466.1 & 630.4 & 0 & 703.0 & 703.0 \\
\hline 1989 & $14,390.7$ & $13,593.0$ & $27,983.7$ & 95.2 & 386.0 & 481.2 & 590.4 & 0 & 773.0 & 773.0 \\
\hline 1990 & $11,820.1$ & $16,257.0$ & $28,077.1$ & 173.6 & 488.0 & 661.6 & 859.5 & 0 & 465.0 & 465.0 \\
\hline 1991 & $14,404.8$ & $9,518.0$ & $23,922.8$ & 96.1 & 186.0 & 282.1 & 634.7 & 2.0 & 642.0 & 644.0 \\
\hline 1992 & $8,835.8$ & $12,691.0$ & $21,526.8$ & 117.3 & 219.0 & 336.3 & 366.8 & 0 & 823.0 & 823.0 \\
\hline
\end{tabular}


Table 18. Water-use information for public water suppliers in Antelope Valley by water-supply sources, 1946-92--Continued

\begin{tabular}{|c|c|c|c|c|c|c|c|c|}
\hline \multirow[t]{2}{*}{ Year } & \multicolumn{3}{|c|}{$\begin{array}{c}\text { Los Angeles } \\
\text { County Waterworks } \\
\text { District No. } 34\end{array}$} & \multirow{2}{*}{$\begin{array}{c}\text { Los Angeles } \\
\text { County Waterworks } \\
\text { District No. } 35 \\
\begin{array}{c}\text { Ground } \\
\text { water }\end{array}\end{array}$} & \multicolumn{3}{|c|}{$\begin{array}{c}\text { Los Angeles } \\
\text { County Waterworks } \\
\text { District No. } 38\end{array}$} & \multirow{2}{*}{$\begin{array}{c}\text { Los Angeles } \\
\text { County Waterworks } \\
\text { District No. } 39\end{array}$} \\
\hline & $\begin{array}{c}\text { Ground } \\
\text { water }\end{array}$ & Purchased & Total & & $\begin{array}{c}\text { Ground } \\
\text { water }\end{array}$ & Purchased & Total & \\
\hline 1946 & 0 & $\ldots$ & 0 & 0 & 0 & - & 0 & 0 \\
\hline 1947 & 0 & -- & 0 & 0 & 0 & -- & 0 & 0 \\
\hline 1948 & 0 & - & 0 & 0 & 188.0 & - & 188.0 & 0 \\
\hline 1949 & 0 & -- & 0 & 0 & 0 & -- & 0 & 0 \\
\hline 1950 & 0 & -- & 0 & 0 & 0 & -- & 0 & 0 \\
\hline 1951 & 0 & -- & 0 & 0 & 0 & -- & 0 & 0 \\
\hline 1952 & 0 & -- & 0 & 0 & 0 & - & 0 & 0 \\
\hline 1953 & 0 & -. & 0 & 316.0 & 0 & -- & 0 & 0 \\
\hline 1954 & 0 & - & 0 & 0 & 0 & - & 0 & 0 \\
\hline 1955 & 0 & -- & 0 & 0 & 0 & -- & 0 & 0 \\
\hline 1956 & 0 & 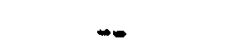 & 0 & 0 & 0 & - & 0 & 0 \\
\hline 1957 & 0 & -- & 0 & 0 & 21.0 & -- & 21.0 & 0 \\
\hline 1958 & 0 & -- & 0 & 0 & 403.0 & -- & 403.0 & 0 \\
\hline 1959 & 0 & -- & 0 & 0 & 10.0 & -- & 10.0 & 0 \\
\hline 1960 & 0 & - & 0 & 0 & 0 & -- & 0 & 0 \\
\hline 1961 & 0 & -- & 0 & 37.0 & 585.0 & - & 585.0 & 0 \\
\hline 1962 & 0 & - & 0 & $0^{\circ}$ & 355.0 & -- & 355.0 & 0 \\
\hline 1963 & 0 & - & 0 & 0 & $1,772.0$ & -- & $1,772.0$ & 0 \\
\hline 1964 & 0 & - & 0 & 1.0 & $1,204.0$ & $-\infty$ & $1,204.0$ & 0 \\
\hline 1965 & 0 & - & 0 & 0 & $3,002.0$ & - & $3,002.0$ & 0 \\
\hline 1966 & 0 & - & 0 & 10.0 & $2,227.0$ & -- & $2,227.0$ & 0 \\
\hline 1967 & 0 & - & 0 & 17.0 & 289.0 & $m$ & 289.0 & 0 \\
\hline 1968 & 0 & - & 0 & 23.0 & $1,150.0$ & - & $1,150.0$ & 0 \\
\hline 1969 & 0 & -- & 0 & 35.0 & $2,600.0$ & -. & $2,600.0$ & 0 \\
\hline 1970 & 0 & - & 0 & 72.0 & 579.0 & - & 579.0 & 0 \\
\hline 1971 & 0 & -- & 0 & 79.0 & 672.0 & .. & 672.0 & 0 \\
\hline 1972 & 0 & - & 0 & $1,630.0$ & 94.0 & -- & 94.0 & 0 \\
\hline 1973 & 0 & - & 0 & 138.0 & 558.0 & - & 558.0 & 0 \\
\hline 1974 & 0 & -- & 0 & 92.0 & 590.0 & -- & 590.0 & 0 \\
\hline 1975 & 0 & -- & 0 & 104.0 & 680.0 & -. & 680.0 & 0 \\
\hline 1976 & 0 & 0 & 0 & 69.0 & 742.0 & 0 & 742.0 & 0 \\
\hline 1977 & 0 & 0 & 0 & 86.0 & 604.0 & 0 & 604.0 & 0 \\
\hline 1978 & 0 & 0 & 0 & $2,055.0$ & 593.0 & 0 & 593.0 & 0 \\
\hline 1979 & 0 & 0 & 0 & 16.7 & 800.1 & 0 & 800.1 & 0 \\
\hline 1980 & 0 & 0 & 0 & .4 & 980.6 & 0 & 980.6 & 0 \\
\hline 1981 & 0 & 0 & 0 & 5.6 & 666.9 & 0 & 666.9 & 0 \\
\hline 1982 & 0 & 0 & 0 & 64.5 & 723.9 & 0 & 723.9 & 0 \\
\hline 1983 & 0 & 0 & 0 & 53.4 & 575.4 & 0 & 575.4 & 0 \\
\hline 1984 & 0 & 0 & 0 & 7.8 & 754.2 & 53.0 & 807.2 & 0 \\
\hline 1985 & 0 & 0 & 0 & 68.2 & 162.5 & 916.0 & $1,078.5$ & 0 \\
\hline 1986 & 0 & 0 & 0 & 42.8 & 961.7 & 673.0 & $1,634,7$ & 0 \\
\hline 1987 & 0 & 0 & 0 & 56.6 & $1,147.8$ & 883.0 & $2,030.8$ & 0 \\
\hline 1988 & 0 & 0 & 0 & 7.5 & $1,029.2$ & $1,260.0$ & $2,289.2$ & 165.2 \\
\hline 1989 & 0 & $1,278.0$ & $1,278.0$ & 2.2 & $1,373.7$ & $1,596.0$ & $2,969.7$ & 167.0 \\
\hline 1990 & 299.4 & $1,607.0$ & $1,906.4$ & 8.1 & 740.2 & $2,100.0$ & $2,840.2$ & 151.5 \\
\hline 1991 & $1,048.7$ & $1,140.0$ & $2,188.7$ & 61.7 & 726.1 & $1,454.0$ & $2,180.1$ & 118.6 \\
\hline 1992 & 258.5 & $2,738.0$ & $2,996.5$ & 86.8 & 200.5 & $2,230.0$ & $2,430.5$ & 239.0 \\
\hline
\end{tabular}


Table 18. Water-use information for public water suppllers in Antelope Valley by water-supply sources, 1946-92--Continued

\begin{tabular}{|c|c|c|c|c|c|c|c|c|c|}
\hline \multirow{2}{*}{ Year } & \multirow{2}{*}{$\begin{array}{c}\text { Land Project } \\
\text { Mutual Water } \\
\text { Company } \\
\text { Ground water }\end{array}$} & \multicolumn{3}{|c|}{$\begin{array}{l}\text { Landale Mutual } \\
\text { Water Company }\end{array}$} & \multirow{2}{*}{$\begin{array}{c}\begin{array}{c}\text { Little Baldy } \\
\text { Water } \\
\text { Company }\end{array} \\
\begin{array}{c}\text { Surface } \\
\text { water }\end{array}\end{array}$} & \multicolumn{4}{|c|}{ Littlerock Creek Irrigation District } \\
\hline & & $\begin{array}{l}\text { Ground } \\
\text { water }\end{array}$ & Purchased & Total & & $\begin{array}{c}\text { Ground } \\
\text { water }\end{array}$ & $\begin{array}{l}\text { Surface } \\
\text { water }\end{array}$ & Purchased & Total \\
\hline$\overline{1946}$ & 0 & 0 & $\overline{--}$ & 0 & $\overline{--}$ & 0 & $2,219.3$ & -- & $2,219.3$ \\
\hline 1947 & 0 & 0 & -- & 0 & 21.7 & $2,966.0$ & $3,583.5$ & -- & $6,549.5$ \\
\hline 1948 & 0 & 0 & -- & 0 & 21.7 & $2,166.0$ & $2,732.3$ & -- & $4,898.3$ \\
\hline 1949 & 0 & 0 & -- & 0 & 21.7 & $2,941.0$ & $1,306.0$ & -- & $4,247.0$ \\
\hline 1950 & 0 & 0 & -- & 0 & 21.7 & $2,495.0$ & 978.0 & -- & $3,473.0$ \\
\hline 1951 & 0 & 0 & -- & 0 & 21.7 & $1,587.0$ & $1,005.0$ & -- & $2,592.0$ \\
\hline 1952 & 0 & 0 & -- & 0 & 21.7 & $1,367.0$ & -- & -- & $1,367.0$ \\
\hline 1953 & 0 & 0 & -- & 0 & 21.7 & $1,687.0$ & -- & -- & $1,687.0$ \\
\hline 1954 & 0 & 0 & -- & 0 & 21.7 & $4,005.0$ & -- & .. & $4,005.0$ \\
\hline 1955 & 0 & 0 & -- & 0 & 21.7 & $4,285.0$ & $2,564.6$ & -- & $6,849.6$ \\
\hline 1956 & 0 & 0 & -. & 0 & 21.7 & $4,902.0$ & $1,868.3$ & -. & $6,770.3$ \\
\hline 1957 & 0 & 0 & -- & 0 & 21.7 & $2,240.0$ & $1,888.4$ & -- & $4,128.4$ \\
\hline 1958 & 0 & 0 & -- & 0 & 21.7 & $1,425.0$ & $2,436.3$ & -- & $3,861.3$ \\
\hline 1959 & 0 & 0 & -- & 0 & 21.7 & $4,037.0$ & $2,040.7$ & -- & $6,077.7$ \\
\hline 1960 & 0 & 0 & -- & 0 & 21.7 & $2,496.0$ & 604.5 & 0 & $3,100.5$ \\
\hline 1961 & 0 & 500.0 & -- & 500.0 & 21.7 & $4,165.0$ & 511.0 & 0 & $4,676.0$ \\
\hline 1962 & 0 & 0 & -- & 0 & 21.7 & $5,461.0$ & $2,142.0$ & 0 & $7,603.0$ \\
\hline 1963 & 0 & 20.0 & -- & 20.0 & 21.7 & $2,122.0$ & 979.0 & 0 & $3,101.0$ \\
\hline 1964 & 0 & 302.0 & -- & 302.0 & 21.7 & $3,693.0$ & $2,018.0$ & 0 & $5,711.0$ \\
\hline 1965 & 0 & 252.0 & -- & 252.0 & 21.7 & $2,967.0$ & $4,704.0$ & 0 & $7,671.0$ \\
\hline 1966 & 0 & 649.0 & .- & 649.0 & 21.7 & $4,357.0$ & 189.0 & 0 & $4,546.0$ \\
\hline 1967 & 0 & 293.0 & -- & 293.0 & -- & $3,505.0$ & $2,357.0$ & 0 & $5,862.0$ \\
\hline 1968 & 0 & 171.0 & -- & 171.0 & 21.7 & $3,227.0$ & $4,878.0$ & 0 & $8,105.0$ \\
\hline 1969 & 0 & 144.0 & -- & 144.0 & 21.7 & $2,630.0$ & $4,663.0$ & 0 & $7,293.0$ \\
\hline 1970 & 0 & 141.0 & -- & 141.0 &.- & $1,350.0$ & $3,208.3$ & 0 & $4,558.3$ \\
\hline 1971 & 0 & 120.0 & -- & 120.0 & 21.7 & $2,897.0$ & $3,052.0$ & 0 & $5,949.0$ \\
\hline 1972 & 0 & 746.0 & -. & 746.0 & 21.7 & $3,566.0$ & $2,857.3$ & 338.0 & $6,761.3$ \\
\hline 1973 & 0 & 278.0 & -- & 278.0 & 21.7 & $2,557.0$ & $3,717.5$ & 290.0 & $6,564.5$ \\
\hline 1974 & 0 & 0 & -- & 0 & 21.7 & $2,369.0$ & $3,302.9$ & 400.0 & $6,071.9$ \\
\hline 1975 & 0 & 251.0 & -- & 251.0 & 21.7 & $2,145.0$ & $3,791.4$ & 520.0 & $6,456.4$ \\
\hline 1976 & 0 & 0 & 0 & 0 & 21.7 & 0 & $2,569.2$ & 589.0 & $3,158.2$ \\
\hline 1977 & 0 & 0 & 0 & 0 & 21.7 & 0 & $2,412.9$ & 111.0 & $2,523.9$ \\
\hline 1978 & 0 & 0 & 0 & 0 & 21.7 & $2,444.3$ & $1,989.9$ & 208.0 & $4,642.2$ \\
\hline 1979 & 0 & 0 & 0 & 0 & 21.7 & $2,480.0$ & $1,932.4$ & 133.0 & $4,545.4$ \\
\hline 1980 & 0 & 245.0 & 0 & 245.0 & 21.7 & $2,515.0$ & $1,718.6$ & 191.0 & $4,424.6$ \\
\hline 1981 & 0 & 245.0 & 0 & 245.0 & 21.7 & $1,385.6$ & $1,806.2$ & $1,270.0$ & $4,461.8$ \\
\hline 1982 & 0 & 0 & 0 & 0 & 21.7 & $2,060.8$ & $1,603.6$ & 0 & $3,664.4$ \\
\hline 1983 & 0 & 255.0 & 0 & 255.0 & 21.7 & $1,672.6$ & $1,199.2$ & 38.0 & $2,909.8$ \\
\hline 1984 & 0 & 0 & 0 & 0 & 21.7 & $2,141.1$ & $1,464.4$ & 1.0 & $3,606.5$ \\
\hline 1985 & 558.5 & 271.0 & 0 & 271.0 & 21.7 & $1,830.0$ & $1,337.3$ & 0 & $3,167.3$ \\
\hline 1986 & 0 & 211.9 & 0 & 211.9 & 21.7 & $2,042.0$ & 903.0 & 163.0 & $3,108.0$ \\
\hline 1987 & 0 & 0 & 0 & 0 & 21.7 & $1,601.0$ & $1,545.0$ & $1,080.0$ & $4,226.0$ \\
\hline 1988 & 0 & 0 & 0 & 0 & 10.0 & 65.7 & $1,445.0$ & 419.0 & $1,929.7$ \\
\hline 1989 & 0 & 229.1 & 0 & 229.1 & 10.0 & $1,593.0$ & $1,145.0$ & 971.0 & $3,709.0$ \\
\hline 1990 & 0 & 206.5 & 0 & 206.5 & 10.0 & $1,526.0$ & -- & $1,747.0$ & $3,273.0$ \\
\hline 1991 & 0 & 0 & 11.0 & 11.0 & - & $1,991.0$ & -- & 858.0 & $2,849.0$ \\
\hline 1992 & 0 & 0 & 1.0 & 1.0 & -- & 0 & -- & -. & 0 \\
\hline
\end{tabular}


Table 18. Water-use information for public water suppliers in Antelope Valley by water-supply sources, 1946-92-Continued

\begin{tabular}{|c|c|c|c|c|c|c|c|c|c|}
\hline \multirow[t]{2}{*}{ Year } & \multicolumn{3}{|c|}{$\begin{array}{l}\text { Mojave Public } \\
\text { Utility District }\end{array}$} & \multirow{2}{*}{$\begin{array}{c}\text { North Edwards } \\
\text { Water } \\
\text { District }\end{array}$} & \multirow{2}{*}{$\begin{array}{c}\begin{array}{c}\text { Northrop } \\
\text { Corporation } \\
\text { B-2 Division }\end{array} \\
\begin{array}{c}\text { Ground } \\
\text { water }\end{array}\end{array}$} & \multirow{2}{*}{$\begin{array}{c}\begin{array}{c}\text { Oak Springs } \\
\text { Valley Water } \\
\text { Company }\end{array} \\
\begin{array}{c}\text { Ground } \\
\text { water }\end{array}\end{array}$} & \multicolumn{3}{|c|}{$\begin{array}{l}\text { Palm Ranch } \\
\text { Irrigation District }\end{array}$} \\
\hline & $\begin{array}{c}\text { Ground } \\
\text { water }\end{array}$ & Purchased & Total & & & & $\begin{array}{c}\text { Ground } \\
\text { water }\end{array}$ & Purchased & Total \\
\hline$\overline{1946}$ & 0 & -- & 0 & 0 & 0 & 0 & 0 & -- & 0 \\
\hline 1947 & 0 & -- & 0 & 0 & 0 & 0 & 307.0 & -- & 307.0 \\
\hline 1948 & 0 & -- & 0 & 0 & 0 & 0 & 307.0 & -- & 307.0 \\
\hline 1949 & 0 & -- & 0 & 0 & 0 & 0 & 935.0 & -- & 935.0 \\
\hline 1950 & 0 & -- & 0 & 0 & 0 & 0 & 307.0 & -- & 307.0 \\
\hline 1951 & 0 & $\ldots$ & 0 & 0 & 0 & 0 & 307.0 & .- & 307.0 \\
\hline 1952 & 0 & - & 0 & 0 & 0 & 0 & 307.0 & -- & 307.0 \\
\hline 1953 & 0 & -. & 0 & 0 & 0 & 0 & 210.0 & -- & 210.0 \\
\hline 1954 & 0 & - & 0 & 0 & 0 & 0 & 307.0 & -- & 307.0 \\
\hline 1955 & 0 & .. & 0 & 0 & 0 & 0 & 320.0 & -- & 320.0 \\
\hline 1956 & 0 & - & 0 & 0 & 0 & 0 & 56.0 & - & 56.0 \\
\hline 1957 & 0 & -. & 0 & 0 & 0 & 0 & 384.0 & -. & 384.0 \\
\hline 1958 & 0 & -- & 0 & 67.0 & 0 & 0 & 472.0 & -- & 472.0 \\
\hline 1959 & 0 & -. & 0 & 108.0 & 0 & 0 & 898.0 & -- & 898.0 \\
\hline 1960 & 0 & - & 0 & 108.0 & 0 & 0 & 483.0 & -- & 483.0 \\
\hline 1961 & 0 & -- & 0 & 106.0 & 0 & 0 & 310.0 & -- & 310.0 \\
\hline 1962 & 0 & -- & 0 & 106.0 & 0 & 0 & 418.0 & -- & 418.0 \\
\hline 1963 & 0 & -. & 0 & 108.0 & 0 & 0 & $1,431.0$ & -. & $1,431.0$ \\
\hline 1964 & 0 & -- & 0 & 110.0 & 0 & 1.0 & 675.0 & -- & 675.0 \\
\hline 1965 & 0 & -- & 0 & 100.0 & 0 & 1.0 & 675.0 & -- & 675.0 \\
\hline 1966 & 0 & -- & 0 & 115.0 & 0 & 1.0 & 466.0 & -. & 466.0 \\
\hline 1967 & 0 & -- & 0 & 120.0 & 0 & 9.0 & 598.0 & .. & 598.0 \\
\hline 1968 & 0 & - & 0 & 127.0 & 0 & 11.0 & 916.0 & -- & 916.0 \\
\hline 1969 & 0 & -- & 0 & 152.0 & 0 & 20.0 & 857.0 & -- & 857.0 \\
\hline 1970 & 0 & -- & 0 & 177.0 & 0 & 23.0 & 815.0 & .- & 815.0 \\
\hline 1971 & 0 & -- & 0 & 180.0 & 0 & 24.0 & 747.0 & -- & 747.0 \\
\hline 1972 & 0 & .. & 0 & 180.0 & 0 & 562.0 & 5.0 & .. & 5.0 \\
\hline 1973 & 0 & -- & 0 & 180.0 & 0 & 24.0 & 953.0 & -- & 953.0 \\
\hline 1974 & 0 & -- & 0 & 188.0 & 0 & 34.0 & $1,021.0$ & -- & $1,021.0$ \\
\hline 1975 & 0 & -- & 0 & 190.0 & 0 & 29.0 & $1,053.0$ & -- & $1,053.0$ \\
\hline 1976 & 0 & 0 & 0 & 190.0 & 0 & 31.0 & $1,101.0$ & 0 & $1,101.0$ \\
\hline 1977 & 0 & 0 & 0 & 190.0 & 0 & 33.0 & $1,007.0$ & 0 & $1,007.0$ \\
\hline 1978 & 0 & 0 & 0 & 190.0 & 0 & 35.0 & 815.0 & 217.0 & $1,032.0$ \\
\hline 1979 & 0 & 150.0 & 150.0 & 190.0 & 0 & 0 & 0 & 307.0 & 307.0 \\
\hline 1980 & 0 & 137.0 & 137.0 & 190.0 & 0 & 40.0 & 322.2 & 779.0 & $1,101.2$ \\
\hline 1981 & 0 & 316.0 & 316.0 & 190.0 & 0 & 0 & 223.7 & 992.0 & $1,215.7$ \\
\hline 1982 & 0 & 358.0 & 358.0 & 190.0 & 0 & 0 & 0 & 591.0 & 591.0 \\
\hline 1983 & 0 & 612.0 & 612.0 & 190.0 & 0 & 0 & 402.3 & 338.0 & 740.3 \\
\hline 1984 & 0 & 563.0 & 563.0 & 275.0 & 0 & 0 & 569.7 & 339.0 & 908.7 \\
\hline 1985 & 0 & 516.0 & 516.0 & 250.0 & 0 & 0 & 753.8 & 407.0 & $1,160.8$ \\
\hline 1986 & 0 & 735.0 & 735.0 & 259.0 & 0 & 0 & 183.5 & 979.0 & $1,162.5$ \\
\hline 1987 & 0 & 696.0 & 696.0 & 245.0 & 0 & 0 & 244.5 & $1,057.0$ & $1,301.5$ \\
\hline 1988 & 0 & 462.0 & 462.0 & 187.0 & 0 & 0 & 0 & 790.0 & 790.0 \\
\hline 1989 & $1,322.0$ & 401.0 & $1,723.0$ & 0 & 0 & 0 & 582.0 & 969.0 & $1,551.0$ \\
\hline 1990 & $1,286.0$ & 288.0 & $1,574.0$ & 0 & 0 & 0 & 451.0 & $1,070.0$ & $1,521.0$ \\
\hline 1991 & $1,213.9$ & 468.0 & $1,681.9$ & 113.4 & 66.9 & 0 & 887.3 & 409.0 & $1,296.3$ \\
\hline 1992 & 0 & 433.0 & 433.0 & 0 & 0 & 0 & 0 & 679.0 & 679.0 \\
\hline
\end{tabular}


Table 18. Water-use information for public water suppilers in Anteiope Valley by water-supply sources, 1946-92-Continued

\begin{tabular}{|c|c|c|c|c|c|c|c|c|c|c|}
\hline \multirow[b]{2}{*}{ Year } & \multicolumn{4}{|c|}{$\begin{array}{c}\text { Palmdale } \\
\text { Water District }\end{array}$} & \multicolumn{3}{|c|}{$\begin{array}{c}\text { Quartz Hill } \\
\text { Water District }\end{array}$} & \multicolumn{3}{|c|}{$\begin{array}{l}\text { Rosamond Community } \\
\text { Service District }\end{array}$} \\
\hline & $\begin{array}{l}\text { Ground } \\
\text { water }\end{array}$ & $\begin{array}{c}\text { Surface } \\
\text { water }\end{array}$ & Purchased & Total & $\begin{array}{l}\text { Ground } \\
\text { water }\end{array}$ & Purchased & Total & $\begin{array}{l}\text { Ground } \\
\text { water }\end{array}$ & Purchased & Total \\
\hline 1946 & 0 & $\overline{--}$ & -- & 0 & $\overline{0}$ & - & 0 & 0 & - & 0 \\
\hline 1947 & $1,865.0$ & -- & -- & $1,865.0$ & 480.0 & -- & 480.0 & 0 & -- & 0 \\
\hline 1948 & $5,478.0$ & -- & -. & $5,478.0$ & 729.0 & -- & 729.0 & 0 & -- & 0 \\
\hline 1949 & $2,747.0$ & -- & -- & $2,747.0$ & 645.0 & .- & 645.0 & 0 & -- & 0 \\
\hline 1950 & $1,732.0$ & -- & -- & $1,732.0$ & 480.0 & -- & 480.0 & 0 & -- & 0 \\
\hline 1951 & $1,259.0$ & -- & -- & $1,259.0$ & 480.0 & .- & 480.0 & 0 & -. & 0 \\
\hline 1952 & $7,107.0$ & -- & -- & $7,107.0$ & 43.0 & -- & 43.0 & 0 & - & 0 \\
\hline 1953 & $2,732.0$ & -- & -- & $2,732.0$ & 480.0 & -- & 480.0 & 0 & - & 0 \\
\hline 1954 & $7,134.0$ & -- & -- & $7,134.0$ & 28.0 & -- & 28.0 & 0 & -- & 0 \\
\hline 1955 & $5,499.0$ & -- & -- & $5,499.0$ & 480.0 & -- & 480.0 & 0 & -- & 0 \\
\hline 1956 & $4,388.0$ & -- & -. & $4,388.0$ & 480.0 & -- & 480.0 & 0 & -- & 0 \\
\hline 1957 & $4,609.0$ & -- & -- & $4,609.0$ & 816.0 & _- & 816.0 & 0 & - & 0 \\
\hline 1958 & $4,244.0$ & - & -- & $4,244.0$ & 170.0 & -- & 170.0 & 0 & - & 0 \\
\hline 1959 & $3,141,0$ & -. & -- & $3,141.0$ & $1,125.0$ & -- & $1,125.0$ & 0 & - & 0 \\
\hline 1960 & $2,993.0$ & -- & 0 & $2,993.0$ & 385.0 & -- & 385.0 & 0 & -- & 0 \\
\hline 1961 & $2,868.0$ & -- & 0 & $2,868.0$ & $1,085.0$ & -- & $1,085.0$ & 0 & - & 0 \\
\hline 1962 & $10,527.0$ & -- & 0 & $10,527.0$ & 334.0 & -- & 334.0 & 0 & -- & 0 \\
\hline 1963 & $2,851.0$ & -- & 0 & $2,851.0$ & $1,037.0$ & -- & $1,037.0$ & 0 & -- & 0 \\
\hline 1964 & $5,883.0$ & -- & 0 & $5,883.0$ & $3,134.0$ & -- & $3,134.0$ & 0 & -- & 0 \\
\hline 1965 & $5,000.0$ & -- & 0 & $5,000.0$ & 605.0 & -- & 605.0 & 0 & -- & 0 \\
\hline 1966 & $5,645.0$ & -- & 0 & $5,645.0$ & 811.0 & -- & 811.0 & 0 & -- & 0 \\
\hline 1967 & $5,394.0$ & -- & 0 & $5,394.0$ & 610.0 & -- & 610.0 & 0 & -- & 0 \\
\hline 1968 & $8,634.0$ & -- & 0 & $8,634.0$ & 212.0 & -- & 212.0 & 0 & -- & 0 \\
\hline 1969 & $6,922.0$ & -- & 0 & $6,922.0$ & $2,914.0$ & -- & $2,914.0$ & 0 & -- & 0 \\
\hline 1970 & $6,144.0$ & -- & 0 & $6,144.0$ & 917.0 & -- & 917.0 & 0 & -- & 0 \\
\hline 1971 & $6,107.0$ & -- & 0 & $6,107.0$ & 922.0 & -- & 922.0 & 0 & -- & 0 \\
\hline 1972 & $5,436.0$ & -- & 0 & $5,436.0$ & 138.0 & -- & 138.0 & 0 & -- & 0 \\
\hline 1973 & $6,041.0$ & -- & 0 & $6,041.0$ & $1,281.0$ & -- & $1,281.0$ & 0 & - & 0 \\
\hline 1974 & $6,030.0$ & -- & 0 & $6,030.0$ & $1,167.0$ & -- & $1,167.0$ & 0 & -- & 0 \\
\hline 1975 & $6,458.0$ & -- & 0 & $6,458.0$ & 0 & -- & 0 & 0 & -- & 0 \\
\hline 1976 & $6,092.0$ & -- & 0 & $6,092.0$ & $1,474.0$ & 0 & $1,474.0$ & 0 & 0 & 0 \\
\hline 1977 & $5,102.0$ & -- & 0 & $5,102.0$ & $1,353.0$ & 0 & $1,353.0$ & 0 & 0 & 0 \\
\hline 1978 & $6,911.1$ & -- & 0 & $6,911.1$ & $1,015.0$ & 568.0 & $1,583.0$ & 0 & 0 & 0 \\
\hline 1979 & $5,999.4$ & -- & 0 & $5,999.4$ & 732.0 & 872.0 & $1,604.0$ & 0 & 21.0 & 21.0 \\
\hline 1980 & $6,125.7$ & -- & 0 & $6,125.7$ & 752.0 & 992.0 & $1,744.0$ & 0 & 3.0 & 3.0 \\
\hline 1981 & $8,092.9$ & -- & 0 & $8,092.9$ & 848.4 & $1,154.0$ & $2,002.4$ & 0 & 6.0 & 6.0 \\
\hline 1982 & $6,713.7$ & -- & 0 & $6,713.7$ & 658.3 & $1,131.0$ & $1,789.3$ & 0 & 11.0 & 11.0 \\
\hline 1983 & $5,059.4$ & -- & 0 & $5,059.4$ & 752.0 & 930.0 & $1,682.0$ & 0 & 64.0 & 64.0 \\
\hline 1984 & $6,177.2$ & -- & 0 & $6,177.2$ & $1,147.0$ & $1,247.0$ & $2,394.0$ & 0 & 76.0 & 76.0 \\
\hline 1985 & $8,296.4$ & -- & $1,558.0$ & $9,854.4$ & 826.2 & $1,601.0$ & $2,427.2$ & 0 & 50.0 & 50.0 \\
\hline 1986 & $7,811.5$ & -- & $3,096.0$ & $10,907.5$ & $1,332.1$ & $1,220.0$ & $2,552.1$ & 0 & 14.0 & 14.0 \\
\hline 1987 & $7,971.4$ & -- & $5,379.0$ & $13,350.4$ & 900.0 & $1,407.0$ & $2,307.0$ & 0 & 20.0 & 20.0 \\
\hline 1988 & 844.0 & -- & $1,770.0$ & $2,614.0$ & 900.0 & $1,133.0$ & $2,033.0$ & 0 & 79.0 & 79.0 \\
\hline 1989 & $10,002.0$ & -- & $9,009.0$ & $19,011.0$ & $1,661.0$ & $1,369.0$ & $3,030.0$ & 775.0 & 159.0 & 934.0 \\
\hline 1990 & $10,208.9$ & -- & $8,608.0$ & $18,816.9$ & $1,190.0$ & $1,950.0$ & $3,140.0$ & 780.0 & 498.0 & $1,278.0$ \\
\hline 1991 & $12,720.1$ & -- & $6,525.0$ & $19,245.1$ & $1,311.0$ & $1,543.0$ & $2,854.0$ & $1,235.4$ & 535.0 & $1,770.4$ \\
\hline 1992 & $10,266.0$ & $3,288.0$ & $4,007.0$ & $17,561.0$ & $1,373.9$ & $1,646.0$ & $3,019.9$ & 0 & 898.0 & 898.0 \\
\hline
\end{tabular}


Table 18. Water-use information for public water suppliers in Antelope Valley by water-supply sources, 1946-92-Continued

\begin{tabular}{|c|c|c|c|c|c|c|c|c|c|}
\hline \multirow{3}{*}{ Year } & \multicolumn{3}{|c|}{$\begin{array}{c}\text { San Bernardino County } \\
\text { Service Area No. } 70 \mathrm{~L}\end{array}$} & \multirow{3}{*}{$\begin{array}{c}\begin{array}{c}\text { Shadow Acres } \\
\text { Mutual Water } \\
\text { Company }\end{array} \\
\text { Purchased }\end{array}$} & \multirow{3}{*}{$\begin{array}{c}\begin{array}{c}\text { Saint } \\
\text { Andrews } \\
\text { Priory }\end{array} \\
\begin{array}{c}\text { Ground } \\
\text { water }\end{array}\end{array}$} & \multirow{3}{*}{$\begin{array}{c}\begin{array}{c}\text { Sunnyside Farms } \\
\text { Mutual Water } \\
\text { Company }\end{array} \\
\text { Purchased }\end{array}$} & \multicolumn{3}{|c|}{$\begin{array}{c}\text { U.S. Borax and } \\
\text { Chemical Corporation }\end{array}$} \\
\hline & \multirow{2}{*}{$\begin{array}{l}\text { Ground } \\
\text { water }\end{array}$} & \multirow{2}{*}{$\begin{array}{l}\text { Surface } \\
\text { water }\end{array}$} & \multirow{2}{*}{ Total } & & & & Ground & Purchased & Total \\
\hline & & & & & & & water & Fuctiased & 10tal \\
\hline 1946 & 0 & -- & 0 & - & 0 & -- & -- & -- & 0 \\
\hline 1947 & 0 & -- & 0 & -- & 0 & -- & -- & -- & 0 \\
\hline 1948 & 0 & -- & 0 & -- & 0 & -- & -- & -- & 0 \\
\hline 1949 & 0 & 17.9 & 17.9 & -- & 550.0 & -- & .- & .- & 0 \\
\hline 1950 & 0 & 17.9 & 17.9 & -- & 0 & -- & -- & -- & 0 \\
\hline 1951 & 0 & 17.9 & 17.9 & -- & 0 & -- & -- & -- & 0 \\
\hline 1952 & 0 & 17.9 & 17.9 & -- & 8.0 & -- & -- & -- & 0 \\
\hline 1953 & 0 & 17.9 & 17.9 & -- & 496.0 & - & -- & -- & 0 \\
\hline 1954 & 0 & 17.9 & 17.9 & -- & 734.0 & -- & -- & -- & 0 \\
\hline 1955 & 0 & 17.9 & 17.9 & -- & 0 & -- & -- & .- & 0 \\
\hline 1956 & 0 & 17.9 & 17.9 & -- & $1,071.0$ & -- & -- & -. & 0 \\
\hline 1957 & 0 & 17.9 & 17.9 & -- & 75.0 & -- & -- & -- & 0 \\
\hline 1958 & 0 & 17.9 & 17.9 & -- & 305.0 & -- & 160.0 & -- & 160.0 \\
\hline 1959 & 0 & 17.9 & 17.9 & -- & 149.0 & -- & $1,015.0$ & -- & $1,015.0$ \\
\hline 1960 & 0 & 17.9 & 17.9 & -- & 103.0 & -- & 865.0 & -- & 865.0 \\
\hline 1961 & 0 & 17.9 & 17.9 & -- & 220.0 & -. & $1,167.0$ & -- & $1,167.0$ \\
\hline 1962 & 0 & 17.9 & 17.9 & -- & 60.0 & -- & $1,294.0$ & -- & $1,294.0$ \\
\hline 1963 & 0 & 24.1 & 24.1 & -- & 308.0 & -- & $1,216.0$ & -- & $1,216.0$ \\
\hline 1964 & 0 & 23.7 & 23.7 & -. & 448.0 & -- & $1,248.0$ & -- & $1,248.0$ \\
\hline 1965 & 0 & 17.9 & 17.9 & -- & 71.0 & -- & $1,397.0$ & -- & $1,397.0$ \\
\hline 1966 & 0 & 10.0 & 10.0 & -- & 65.0 & -- & $1,506.0$ & -- & $1,506.0$ \\
\hline 1967 & 0 & 11.0 & 11.0 & -- & 65.0 & -- & $1,494.0$ & -- & $1,494.0$ \\
\hline 1968 & 0 & 17.0 & 17.0 & -- & 24.0 & -- & $1,525.0$ & -- & $1,525.0$ \\
\hline 1969 & 0 & 22.0 & 22.0 & -- & 10.0 & -- & $1,890.0$ & -- & $1,890.0$ \\
\hline 1970 & 0 & 25.4 & 25.4 & -- & 60.0 & -- & $1,801.0$ & -- & $1,801.0$ \\
\hline 1971 & 0 & 29.0 & 29.0 & -- & 75.0 & -- & $1,762.0$ & .. & $1,762.0$ \\
\hline 1972 & 0 & 28.8 & 28.8 & -- & 0 & .- & $1,770.0$ & -- & $1,770.0$ \\
\hline 1973 & 0 & 27.1 & 27.1 & .- & 102.0 & -- & $2,166.0$ & -- & $2,166.0$ \\
\hline 1974 & 0 & 29.1 & 29.1 & -- & 98.0 & -- & $2,202.0$ & -- & $2,202.0$ \\
\hline 1975 & 0 & 24.5 & 24.5 & -- & 96.0 & -- & $2,619.0$ & -- & $2,619.0$ \\
\hline 1976 & 0 & 17.9 & 17.9 & 0 & 92.0 & 0 & $2,956.0$ & 0 & $2,956.0$ \\
\hline 1977 & 0 & 20.3 & 20.3 & 0 & 69.0 & 0 & $2,970.0$ & 0 & $2,970.0$ \\
\hline 1978 & 0 & 12.4 & 12.4 & 0 & 68.0 & 111.0 & $2,924.0$ & 0 & $2,924.0$ \\
\hline 1979 & 0 & 23.0 & 23.0 & 0 & 0 & 148.0 & $2,726.0$ & 0 & $2,726.0$ \\
\hline 1980 & 0 & 32.0 & 32.0 & 0 & 63.0 & 159.0 & $2,476.0$ & 935.0 & $3,411.0$ \\
\hline 1981 & 0 & 35.9 & 35.9 & 0 & 135.0 & 182.0 & $2,248.0$ & $1,415.0$ & $3,663.0$ \\
\hline 1982 & 0 & 35.9 & 35.9 & 0 & 143.0 & 150.0 & $1,729.0$ & $1,039.0$ & $2,768.0$ \\
\hline 1983 & 0 & 35.9 & 35.9 & 0 & 0 & 129.0 & $1,448.0$ & 841.0 & $2,289.0$ \\
\hline 1984 & 0 & 35.9 & 35.9 & 0 & 199.2 & 273.0 & $1,285.0$ & $1,109.0$ & $2,394.0$ \\
\hline 1985 & 0 & 35.9 & 35.9 & 0 & 236.9 & 183.0 & $1,555.0$ & 651.0 & $2,206.0$ \\
\hline 1986 & 336.0 & 35.9 & 371.9 & 0 & 147.7 & 196.0 & $1,697.0$ & 605.0 & $2,302.0$ \\
\hline 1987 & 247.6 & 35.9 & 283.5 & 0 & 163.0 & 207.0 & $1,789.0$ & 678.0 & $2,467.0$ \\
\hline 1988 & 280.4 & 35.9 & 316.3 & 13.0 & 0 & 227.0 & $1,954.0$ & 735.0 & $2,689.0$ \\
\hline 1989 & 261.8 & 35.9 & 297.7 & 93.0 & 218.0 & 258.0 & $1,722.0$ & 682.0 & $2,404.0$ \\
\hline 1990 & 578.2 & 35.9 & 614.1 & 131.0 & 0 & 223.0 & $1,682.0$ & 865.0 & $2,547.0$ \\
\hline 1991 & 672.0 & 35.9 & 707.9 & 123.0 & 0 & 184.0 & $1,214.0$ & $1,261.0$ & $2,475.0$ \\
\hline 1992 & 0 & 35.9 & 35.9 & 133.0 & 0 & 226.0 & -- & $1,084.0$ & $1,084.0$ \\
\hline
\end{tabular}


Table 18. Water-use information for publlc water suppliers in Antelope Vailey by water-supply sources, 1946-92-Continued

\begin{tabular}{|c|c|c|c|c|c|c|c|c|c|c|}
\hline \multirow{3}{*}{ Year } & \multirow{3}{*}{$\begin{array}{c}\text { USAF } \\
\text { Plant 42 } \\
\text { (Rockwell) } \\
\begin{array}{c}\text { Ground } \\
\text { water }\end{array}\end{array}$} & \multirow{3}{*}{$\frac{\begin{array}{c}\text { West Side Park } \\
\text { Mutual Water } \\
\text { Company }\end{array}}{\begin{array}{c}\text { Ground } \\
\text { water }\end{array}}$} & \multirow{2}{*}{\multicolumn{3}{|c|}{$\begin{array}{l}\text { White Fence Farms } \\
\text { Mutual Water Company }\end{array}$}} & \multicolumn{4}{|c|}{ Public water suppliers } & \multirow{3}{*}{$\begin{array}{l}\text { No. of } \\
\text { suppliers } \\
\text { (of } 40 \text { ) }\end{array}$} \\
\hline & & & & & & \multirow{2}{*}{$\begin{array}{l}\text { Total } \\
\text { ground } \\
\text { water }\end{array}$} & \multirow{2}{*}{$\begin{array}{l}\text { Total } \\
\text { surface } \\
\text { water }\end{array}$} & \multirow[b]{2}{*}{$\begin{array}{c}\text { Total } \\
\text { purchased }\end{array}$} & \multirow[b]{2}{*}{$\begin{array}{l}\text { Grand } \\
\text { total }\end{array}$} & \\
\hline & & & $\begin{array}{c}\text { Ground } \\
\text { water }\end{array}$ & Purchased & Total & & & & & \\
\hline$\overline{1946}$ & 0 & 0 & 0 & $\overline{--}$ & $\overline{0}$ & 600.0 & $2,219.3$ & 0 & $2,819.3$ & 3 \\
\hline 1947 & 0 & 0 & 0 & -- & 0 & $6,758.0$ & $3,605.2$ & 0 & $10,363.2$ & 9 \\
\hline 1948 & 0 & 0 & 0 & -- & 0 & $11,024.0$ & $2,754.0$ & 0 & $13,778.0$ & 12 \\
\hline 1949 & 0 & 0 & 0 & -- & 0 & $9,995.0$ & $1,345.6$ & 0 & $11,340.6$ & 12 \\
\hline 1950 & 0 & 0 & 0 & -- & 0 & $6,641.0$ & $1,017.6$ & 0 & $7,658.6$ & 12 \\
\hline 1951 & 0 & 0 & 0 & -- & 0 & $5,971.0$ & $1,044.6$ & 0 & $7,015.6$ & 13 \\
\hline 1952 & 0 & 0 & 0 & -- & 0 & $12,460.0$ & 39.6 & 0 & $12,499.6$ & 12 \\
\hline 1953 & 0 & 0 & 0 & -- & 0 & $12,453.0$ & 39.6 & 0 & $12,492.6$ & 15 \\
\hline 1954 & 0 & 0 & 0 & -- & 0 & $16,781.0$ & 39.6 & 0 & $16,820.6$ & 14 \\
\hline 1955 & 0 & 0 & 0 & -- & 0 & $15,413.0$ & $2,604.3$ & 0 & $18,017.3$ & 13 \\
\hline 1956 & 0 & 0 & 0 & -- & 0 & $18,340.0$ & $1,908.0$ & 0 & $20,248.0$ & 14 \\
\hline 1957 & 0 & 0 & 0 & -- & 0 & $16,997.0$ & $1,928.0$ & 0 & $18,925.0$ & 15 \\
\hline 1958 & 0 & 0 & 0 & -- & 0 & $15,716.0$ & $2,475.9$ & 0 & $18,191.9$ & 18 \\
\hline 1959 & 0 & 0 & 211.0 & .- & 211.0 & $20,991.0$ & $2,080.4$ & 0 & $23,071.4$ & 19 \\
\hline 1960 & 0 & 0 & 225.0 & -- & 225.0 & $18,037.0$ & 644.1 & 0 & $18,681.1$ & 18 \\
\hline 1961 & 0 & 0 & 87.0 & -- & 87.0 & $27,799.0$ & 550.6 & 0 & $28,349.6$ & 23 \\
\hline 1962 & 0 & 0 & 736.0 & -- & 736.0 & $36,102.0$ & $2,181.6$ & 0 & $38,283.6$ & 20 \\
\hline 1963 & 0 & 0 & 213.0 & -- & 213.0 & $25,409.0$ & $1,024.8$ & 0 & $26,433.8$ & 22 \\
\hline 1964 & 0 & 0 & 206.0 & -- & 206.0 & $33,047.0$ & $2,063.4$ & 0 & $35,110.4$ & 24 \\
\hline 1965 & 0 & 0 & 526.0 & .- & 526.0 & $31,224.0$ & $4,743.6$ & 0 & $35,967.6$ & 25 \\
\hline 1966 & 0 & 0 & 174.0 & -- & 174.0 & $33,894.0$ & 220.7 & 0 & $34,114.7$ & 25 \\
\hline 1967 & 0 & 0 & $1,084.0$ & -- & $1,084.0$ & $32,694.0$ & $2,368.0$ & 0 & $35,062.0$ & 25 \\
\hline 1968 & 0 & 0 & 640.0 & -- & 640.0 & $30,239.0$ & $4,916.7$ & 0 & $35,155.7$ & 23 \\
\hline 1969 & 0 & 0 & $1,333.0$ & -- & $1,333.0$ & $35,348.0$ & $4,706.7$ & 0 & $40,054.7$ & 24 \\
\hline 1970 & 0 & 0 & 561.0 & -- & 561.0 & $27,577.0$ & $3,233.7$ & 0 & $30,810.7$ & 21 \\
\hline 1971 & 0 & 0 & 526.0 & -- & 526.0 & $29,382.0$ & $3,102.8$ & 0 & $32,484.8$ & 24 \\
\hline 1972 & 0 & 0 & $1,012.0$ & -- & $1,012.0$ & $32,896.0$ & $2,907.8$ & 338.0 & $36,141.8$ & 22 \\
\hline 1973 & 0 & 0 & 559.0 & -- & 559.0 & $32,696.0$ & $3,766.3$ & 290.0 & $36,752.3$ & 23 \\
\hline 1974 & 0 & 0 & 596.0 & -- & 596.0 & $30,249.0$ & $3,353.7$ & 400.0 & $34,002.7$ & 22 \\
\hline 1975 & 0 & 0 & 501.0 & -- & 501.0 & $28,936.0$ & $3,837.6$ & 520.0 & $33,293.6$ & 22 \\
\hline 1976 & 0 & 0 & 540.0 & 0 & 540.0 & $34,353.0$ & $2,608.8$ & 589.0 & $37,550.8$ & 23 \\
\hline 1977 & 0 & 0 & 433.0 & 9.0 & 442.0 & $30,542.0$ & $2,454.9$ & 120.0 & $33,116.9$ & 23 \\
\hline 1978 & 0 & 0 & 470.0 & 110.0 & 580.0 & $41,711.5$ & $2,024.0$ & $5,570.0$ & $49,305.5$ & 24 \\
\hline 1979 & 0 & 104.0 & 0 & 150.0 & 150.0 & $23,258.8$ & $1,977.1$ & $7,650.0$ & $32,886.0$ & 23 \\
\hline 1980 & 0 & 113.3 & 256.8 & 160.0 & 416.8 & $24,822.5$ & $1,772.3$ & $8,284.0$ & $34,878.8$ & 26 \\
\hline 1981 & 0 & 117.8 & 552.3 & 185.0 & 737.3 & $30,814.5$ & $1,863.8$ & $12,178.0$ & $44,856.3$ & 27 \\
\hline 1982 & 0 & 113.9 & 491.6 & 181.0 & 672.6 & $29,492.0$ & $1,661.2$ & $8,253.0$ & $39,406.2$ & 27 \\
\hline 1983 & 0 & 120.8 & 518.8 & 390.0 & 908.8 & $24,611.3$ & $1,256.8$ & $7,936.0$ & $33,804.1$ & 28 \\
\hline 1984 & 0 & 139.1 & 401.2 & 510.0 & 911.2 & $31,040.3$ & $1,522.0$ & $12,050.0$ & $44,612.3$ & 28 \\
\hline 1985 & 0 & 149.1 & 462.0 & 470.0 & 932.0 & $30,309.7$ & $1,394.8$ & $15,534.0$ & $47,238.5$ & 30 \\
\hline 1986 & 0 & 160.6 & 671.8 & 325.0 & 996.8 & $35,244.9$ & 960.6 & $19,164.0$ & $55,369.5$ & 30 \\
\hline 1987 & 0 & 158.8 & 742.0 & 438.0 & $1,180.0$ & $35,429.1$ & $1,602.6$ & $23,548.0$ & $60,579.7$ & 29 \\
\hline 1988 & 0 & 163.3 & 729.8 & 419.0 & $1,148.8$ & $24,914.3$ & $1,490.9$ & $21,745.0$ & $48,150.2$ & 28 \\
\hline 1989 & 0 & 200.8 & 367.6 & 891.0 & $1,258.6$. & $43,097.6$ & $1,190.9$ & $33,298.0$ & $77,586.0$ & 33 \\
\hline 1990 & 0 & 168.9 & 787.6 & 775.0 & 1.562 .6 & $39,400.0$ & 45.9 & $37,722.0$ & $77,167.9$ & 30 \\
\hline 1991 & 159.2 & 186.0 & 455.8 & 482.0 & 937.8 & $45,207.7$ & 35.9 & $25,894.0$ & $71,137.6$ & 35 \\
\hline 1992 & 0 & 0 & 0 & 413.0 & 413.0 & 25.803 .3 & $3,323.9$ & $28,791.0$ & 57.918 .2 & 27 \\
\hline
\end{tabular}


Table 19. Water-use information for self-supplied water users in Antelope Valley by water-supply sources, 1946-92

[Units are in acre-feet. Note: Purchased water may not agree with imported water because it may include purchases from other water suppliers within the Antelope Valley. All values may not add to totals because of independent rounding, --, no data available]

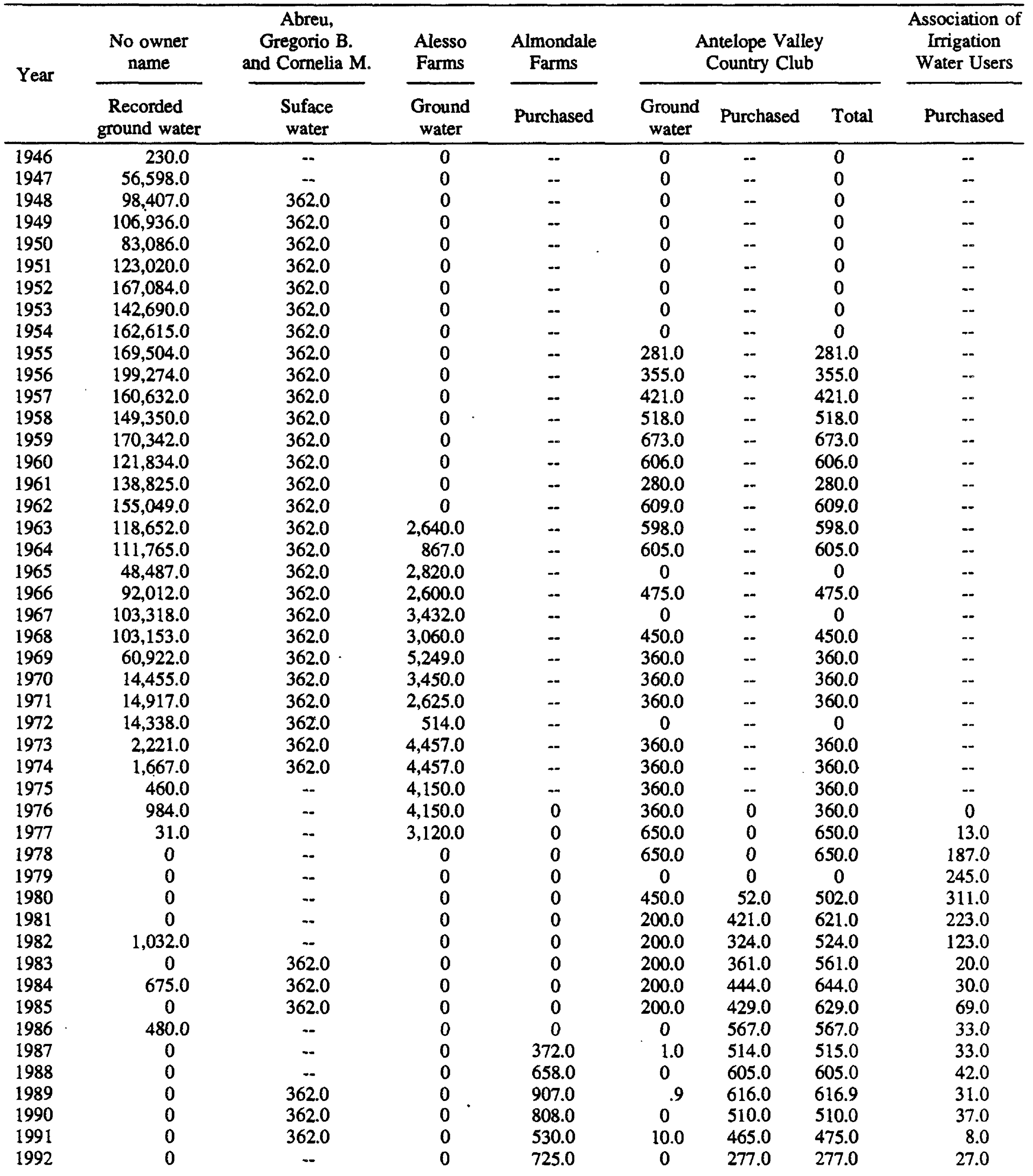


Table 19. Water-use information for seif-supplled water users in Antelope Valley by water-supply sources, 1946-92--Continued

\begin{tabular}{|c|c|c|c|c|c|c|c|c|c|}
\hline \multirow{2}{*}{ Year } & \multicolumn{3}{|c|}{$\begin{array}{l}\text { Baicy, } \\
\text { John }\end{array}$} & \multirow{2}{*}{$\begin{array}{c}\text { Ball, } \\
\begin{array}{c}\text { William C., Junior, } \\
\text { and Mildred P. }\end{array} \\
\begin{array}{c}\text { Surface } \\
\text { water }\end{array}\end{array}$} & \multicolumn{3}{|c|}{$\begin{array}{l}\text { Berry } \\
\text { Ranch }\end{array}$} & \multirow{2}{*}{$\begin{array}{c}\begin{array}{c}\text { Bispaichipy } \\
\text { Ranch }\end{array} \\
\text { Purchased }\end{array}$} & \multirow{2}{*}{$\begin{array}{c}\begin{array}{c}\text { Bio Gro } \\
\text { Systems, } \\
\text { Incorporated }\end{array} \\
\text { Purchased }\end{array}$} \\
\hline & $\begin{array}{c}\text { Ground } \\
\text { water }\end{array}$ & Purchased & Total & & $\begin{array}{c}\text { Ground } \\
\text { water }\end{array}$ & Purchased & Total & & \\
\hline 1946 & -- & - & 0 & -- & - & -- & $\overline{0}$ & -- & -- \\
\hline 1947 & -- & -- & 0 & -. & -- & -- & 0 & -- & .- \\
\hline 1948 & -- & -- & 0 & -- & -- & -- & 0 & -- & -- \\
\hline 1949 & -- & -- & 0 & 22.4 & -- & -- & 0 & -- & -- \\
\hline 1950 & -- & -- & 0 & 22.4 & -- & -- & 0 & -- & -- \\
\hline 1951 & -- & -- & 0 & 22.4 & -- & -- & 0 & -- & -- \\
\hline 1952 & -- & -- & 0 & 22.4 & -- & -- & 0 & -- & -- \\
\hline 1953 & -- & -- & 0 & 22.4 & -- & -- & 0 & -- & -- \\
\hline 1954 & -- & -- & 0 & 22.4 & -- & -- & 0 & -- & -- \\
\hline 1955 & -- & -- & 0 & 22.4 & -- & -- & 0 & -- & -- \\
\hline 1956 & -- & -. & 0 & 22.4 & -. & -- & 0 & -- & -- \\
\hline 1957 & -- & -- & 0 & 22.4 & -- & -- & 0 & -- & -- \\
\hline 1958 & -- & -- & 0 & 22.4 & -- & -- & 0 & -- & -- \\
\hline 1959 & -- & -- & 0 & 22.4 & -- & -- & 0 & -- & -. \\
\hline 1960 & -- & -- & 0 & 22.4 & -- & -- & 0 & -- & -- \\
\hline 1961 & -- & -- & 0 & 22.4 & -- & -- & 0 & -- & -- \\
\hline 1962 & -- & -- & 0 & 22.4 & -- & -- & 0 & -- & -- \\
\hline 1963 & - & -- & 0 & 22.4 & -- & -- & 0 & -- & -- \\
\hline 1964 & -. & -. & 0 & 22.4 & -. & -. & 0 & -- & -- \\
\hline 1965 & -- & -- & 0 & 22.4 & -- & -- & 0 & -- & -- \\
\hline 1966 & .- & .. & 0 & 22.4 & .- & .- & 0 & .- & -- \\
\hline 1967 & -- & -- & 0 & - & -- & $\ldots$ & 0 & - & -- \\
\hline 1968 & .- & .. & 0 & 22.4 & .- & .- & 0 & .- & -- \\
\hline 1969 & -- & -- & 0 & 22.4 & -- & -- & 0 & -- & -- \\
\hline 1970 & .- & .- & 0 & 22.4 & .- & .- & 0 & .- & -- \\
\hline 1971 & -. &.- & 0 & 22.4 & -- & -- & 0 & - & -- \\
\hline 1972 & -- & -- & 0 & 22.4 & .- & -- & 0 & -- & -- \\
\hline 1973 & -- & -- & 0 & 22.4 & -- & -- & 0 & -- & -- \\
\hline 1974 & -- & -- & 0 & 22.4 & -- & -- & 0 & -- & -- \\
\hline 1975 & -- & -- & 0 & 22.4 & -- & -- & 0 & -- & -- \\
\hline 1976 & -- & 0 & 0 & 22.4 & -- & 0 & 0 & 0 & 0 \\
\hline 1977 & -- & 490.0 & 490.0 & 22.4 & -- & 0 & 0 & 575.0 & 567.0 \\
\hline 1978 & -- & $1,506.0$ & $1,506.0$ & 22.4 & -- & $1,679.0$ & $1,679.0$ & $1,053.0$ & $1,946.0$ \\
\hline 1979 & -- & $1,595.0$ & $1,595.0$ & $m$ & -- & $2,329.0$ & $2,329.0$ & $2,096.0$ & $2,468.0$ \\
\hline 1980 & .- & $1,472.0$ & $1,472.0$ & 22.4 & .- & $2,523.0$ & $2,523.0$ & $1,839.0$ & $2,584.0$ \\
\hline 1981 & -- & $2,083.0$ & $2,083.0$ & 22.4 & -- & $3,257.0$ & $3,257.0$ & $3,076.0$ & $3,176.0$ \\
\hline 1982 & -- & $1,418.0$ & $1,418.0$ & 22.4 & -- & $2,644.0$ & $2,644.0$ & $1,703.0$ & $2,420.0$ \\
\hline 1983 & -- & 994.0 & 994.0 & 22.4 & -- & $1,856.0$ & $1,856.0$ & $2,266.0$ & $1,851.0$ \\
\hline 1984 & -- & 651.0 & 651.0 & 22.4 & -- & 139.0 & 139.0 & $1,795.0$ & $2,358.0$ \\
\hline 1985 & -- & 600.0 & 600.0 & 22.4 & -- & $1,954.0$ & $1,954.0$ & $1,059.0$ & $1,863.0$ \\
\hline 1986 & -- & 50.0 & 50.0 & 22.4 & -- & $2,148.0$ & $2,148.0$ & $1,270.0$ & 595.0 \\
\hline 1987 & -- & 0 & 0 & 22.4 & -- & $1,902.0$ & $1,902.0$ & 667.0 & 804.0 \\
\hline 1988 & -- & 229.0 & 229.0 & 22.4 & -- & $2,057.0$ & $2,057.0$ & $1,781.0$ & 975.0 \\
\hline 1989 & -- & 0 & 0 & 22.4 & -- & $2,189.0$ & $2,189.0$ & $2,104.0$ & 676.0 \\
\hline 1990 & -- & 0 & 0 & 22.4 & -- & $2,099.0$ & $2,099.0$ & $2,437.0$ & 0 \\
\hline 1991 & $1,799.0$ & $-1,799.0$ & 0 & 0 & $2,161.0$ & $-2,161.0$ & 0 & 0 & 0 \\
\hline 1992 & -- & 0 & 0 & -- & -- & 0 & 0 & 0 & 253.0 \\
\hline
\end{tabular}


Table 19. Water-use information for self-supplied water users in Antelope Valley by water-supply sources, 1946-92-Continued

\begin{tabular}{|c|c|c|c|c|c|c|c|c|c|c|c|}
\hline \multirow{2}{*}{ Year } & \multirow{2}{*}{$\begin{array}{c}\begin{array}{c}\text { Blalock-Eddy } \\
\text { Ranch } \\
\text { Corporation }\end{array} \\
\begin{array}{c}\text { Surface } \\
\text { water }\end{array}\end{array}$} & \multirow{2}{*}{$\frac{\begin{array}{c}\text { Blua, } \\
\text { Andrew }\end{array}}{\begin{array}{c}\text { Ground } \\
\text { water }\end{array}}$} & \multicolumn{3}{|c|}{ Bonnie AC Ranch } & \multirow{2}{*}{$\begin{array}{c}\text { Boy } \\
\begin{array}{c}\text { Scouts of } \\
\text { America }\end{array} \\
\begin{array}{c}\text { Surface } \\
\text { water }\end{array}\end{array}$} & \multicolumn{3}{|c|}{ Bozigian Ranch } & \multirow{2}{*}{$\begin{array}{c}\begin{array}{c}\text { Bryden, } \\
\text { Lloyd } \\
\text { W. }\end{array} \\
\begin{array}{c}\text { Ground } \\
\text { water }\end{array}\end{array}$} & \multirow{2}{*}{$\begin{array}{c}\text { Buchanan, } \\
\text { Thomas J. \& } \\
\text { Virginia A. } \\
\begin{array}{c}\text { Surface } \\
\text { water }\end{array}\end{array}$} \\
\hline & & & $\begin{array}{l}\text { Ground } \\
\text { water }\end{array}$ & $\begin{array}{c}\text { Surface } \\
\text { water }\end{array}$ & Total & & $\begin{array}{c}\text { Ground } \\
\text { water }\end{array}$ & $\begin{array}{l}\text { Pur- } \\
\text { chased }\end{array}$ & Total & & \\
\hline 1946 & -. & 0 & 0 & -- & 0 & -- & -. & $\cdots$ & 0 & 0 & 0.5 \\
\hline 1947 & -- & 0 & 0 & -- & 0 & -- & -- & -- & 0 & 6.0 & .5 \\
\hline 1948 & -- & 480.0 & 0 & -- & 0 & -- & -- & -- & 0 & 5.0 & .5 \\
\hline 1949 & -- & 0 & 591.0 & $3,388.2$ & $3,979.2$ & -- & -- & -- & 0 & 4.0 & .5 \\
\hline 1950 & -- & 0 & 0 & $3,388.2$ & $3,388.2$ & -- & -- & -- & 0 & 2.0 & .5 \\
\hline 1951 & -- & 0 & 0 & $3,388.2$ & $3,388.2$ & -- & -- & -- & 0 & 2.0 & .5 \\
\hline 1952 & -- & 660.0 & 0 & $1,500.0$ & $1,500.0$ & -- & -- & -- & 0 & 2.0 & .5 \\
\hline 1953 & -- & 658.0 & 130.0 & $1,200.0$ & $1,330.0$ & 23.2 & -- & -- & 0 & 3.0 & .5 \\
\hline 1954 & 800.0 & 640.0 & 0 & $1,200.0$ & $1,200.0$ & 23.2 & -- & -- & 0 & 471.0 & .5 \\
\hline 1955 & 800.0 & 651.0 & 960.0 & $1,200.0$ & $2,160.0$ & 23.2 & -- & -- & 0 & 2.0 & .5 \\
\hline 1956 & 800.0 & 43.0 & 960.0 & $1,600.0$ & $2,560.0$ & 23.2 & -- & -- & 0 & 196.0 & .5 \\
\hline 1957 & 800.0 & 620.0 & $1,111.0$ & $1,600.0$ & $2,711.0$ & 23.2 & -- & -- & 0 & 655.0 & .5 \\
\hline 1958 & 800.0 & 780.0 & 960.0 & $1,600.0$ & $2,560.0$ & 23.2 & -- & -- & 0 & $1,294.0$ & .5 \\
\hline 1959 & $1,000.0$ & 809.0 & 960.0 & $1,500.0$ & $2,460.0$ & 23.2 & $\therefore-$ & -- & 0 & $1,104.0$ & .5 \\
\hline 1960 & 850.0 & $2,700.0$ & 960.0 & $1,500.0$ & $2,460.0$ & 23.2 & -- & -- & 0 & 801.0 & .5 \\
\hline 1961 & $1,100.0$ & 20.0 & 960.0 & $1,500.0$ & $2,460.0$ & 23.2 & -- & -- & 0 & 515.0 & .5 \\
\hline 1962 & 900.0 & 960.0 & $1,796.0$ & $1,500.0$ & $3,296.0$ & 23.2 & -- & -- & 0 & 953.0 & .5 \\
\hline 1963 & -- & $3,220.0$ & 960.0 & $1,500.0$ & $2,460.0$ & 23.2 & -- & -- & 0 & $2,441.0$ & .5 \\
\hline 1964 & 680.0 & $1,100.0$ & 960.0 & $1,500.0$ & $2,460.0$ & 23.2 & -- & -- & 0 & $1,248.0$ & .5 \\
\hline 1965 & 690.0 & $1,210.0$ & 960.0 & $1,500.0$ & $2,460.0$ & 23.2 & -- & -- & 0 & 0 & .5 \\
\hline 1966 & 700.0 & $1,797.0$ & 960.0 & $1,500.0$ & $2,460.0$ & 23.2 & -- & -- & 0 & $1,250.0$ & .5 \\
\hline 1967 & $2,171.9$ & 0 & $1,380.0$ & $1,500.0$ & $2,880.0$ & 23.2 & -- & -- & 0 & 985.0 & .5 \\
\hline 1968 & $2,171.9$ & $4,630.0$ & 960.0 & $3,388.2$ & $4,348.2$ & 23.2 & -- & -- & 0 & $2,162.0$ & .5 \\
\hline 1969 & $2,171.9$ & $3,330.0$ & 960.0 & $3,388.2$ & $4,348.2$ & 23.2 & -- & -- & 0 & 943.0 & .5 \\
\hline 1970 & $2,171.9$ & $4,650.0$ & 960.0 & $3,388.2$ & $4,348.2$ & 23.2 & - & -- & 0 & 761.0 & .5 \\
\hline 1971 & $2,171.9$ & $4,650.0$ & 940.0 & $3,388.2$ & $4,328.2$ & 23.2 & -- & -- & 0 & 0 & .5 \\
\hline 1972 & $2,171.9$ & 764.0 & $1,018.0$ & $3,388.2$ & $4,406.2$ & 23.2 & -- & -- & 0 & 0 & -- \\
\hline 1973 & $2,171.9$ & 0 & 960.0 & $3,388.2$ & $4,348.2$ & 23.2 & -- & -- & 0 & 0 & -- \\
\hline 1974 & $2,171.9$ & 0 & 960.0 & $3,388.2$ & $4,348.2$ & 23.2 & -- & -- & 0 & 0 & -- \\
\hline 1975 & $2,171.9$ & $4,700.0$ & 480.0 & $3,388.2$ & $3,868.2$ & 30.0 & -. & .- & 0 & 0 & -- \\
\hline 1976 & $2,171.9$ & $4,700.0$ & 960.0 & $3,388.2$ & $4,348.2$ & -- & -- & 0 & 0 & 0 & -- \\
\hline 1977 & $2,171.9$ & $4,700.0$ & 960.0 & $3,388.2$ & $4,348.2$ & -- & -- & 192.0 & 192.0 & 80.0 & -- \\
\hline 1978 & $2,171.9$ & 0 & 960.0 & $3,388.2$ & $4,348.2$ & 23.2 & -- & $1,328.0$ & $1,328.0$ & 0 & 0 \\
\hline 1979 & 374.0 & 0 & 960.0 & -- & 960.0 & 23.2 & -- & $1,634.0$ & $1,634.0$ & 0 & -. \\
\hline 1980 & 375.0 & 0 & 960.0 & 375.0 & $1,335.0$ & 23.2 & -- & $1,582.0$ & $1,582.0$ & 0 & -- \\
\hline 1981 & 638.0 & 0 & 960.0 & 638.0 & $1,598.0$ & 23.2 & -- & $1,853.0$ & $1,853.0$ & 0 & -- \\
\hline 1982 & 869.0 & 0 & 960.0 & 869.0 & $1,829.0$ & 23.2 & -- & $1,570.0$ & $1,570.0$ & 0 & -- \\
\hline 1983 & 934.0 & 0 & 960.0 & 934.0 & $1,894.0$ & 23.2 & .. & $1,220.0$ & $1,220.0$ & 0 & -. \\
\hline 1984 & $1,104.0$ & 0 & 0 & $1,104.0$ & $1,104.0$ & 23.2 & -- & $1,007.0$ & $1,007.0$ & 0 & -- \\
\hline 1985 & $1,184.0$ & 0 & 960.0 & $1,184.0$ & $2,144.0$ & -- & -. & $1,075.0$ & $1,075.0$ & 0 & -- \\
\hline 1986 & $1,065.0$ & 0 & 480.0 & $1,065.0$ & $1,545.0$ & -- & -- & 607.0 & 607.0 & 0 & -- \\
\hline 1987 & 880.0 & 0 & 0 & 692.0 & 692.0 & -- & -- & 2.0 & 2.0 & 0 & -- \\
\hline 1988 & 979.0 & 0 & 0 & 979.0 & 979.0 & 23.2 & -- & 2.0 & 2.0 & 0 & -- \\
\hline 1989 & 692.0 & 0 & 0 & 880.0 & 880.0 & 23.2 & -- & 0 & 0 & 0 & -- \\
\hline 1990 & -- & 0 & 0 & 582.0 & 582.0 & 23.2 & -- & 0 & 0 & 0 & -- \\
\hline 1991 & -- & 0 & 0 & 378.0 & 378.0 & -- & 896.0 & -896.0 & 0 & 0 & -- \\
\hline 1992 & -- & 0 & 0 & - & 0 & -- & -- & 0 & 0 & 0 & -- \\
\hline
\end{tabular}


Table 19. Water-use information for self-supplied water users in Antelope Valley by water-supply sources, 1946-92-Continued

\begin{tabular}{|c|c|c|c|c|c|c|c|c|c|c|}
\hline \multirow{2}{*}{ Year } & \multirow{2}{*}{$\begin{array}{c}\begin{array}{c}\text { Bushnell, } \\
\text { David P. }\end{array} \\
\begin{array}{c}\text { Ground } \\
\text { water }\end{array}\end{array}$} & \multicolumn{3}{|c|}{ Calandri Ranch } & \multicolumn{3}{|c|}{$\begin{array}{l}\text { California } \\
\text { Portland Cement } \\
\text { Company }\end{array}$} & \multirow{2}{*}{$\begin{array}{c}\text { California } \\
\text { Resources } \\
\text { Enterprises } \\
\text { Incorporated } \\
\begin{array}{c}\text { Ground } \\
\text { water }\end{array} \\
\end{array}$} & \multirow{2}{*}{$\begin{array}{c}\text { Calmat } \\
\text { Company }\end{array}$} & \multirow{2}{*}{$\begin{array}{c}\text { Cameo } \\
\text { Ranching } \\
\text { Company }\end{array}$} \\
\hline & & $\begin{array}{l}\text { Ground } \\
\text { water }\end{array}$ & $\begin{array}{c}\text { Pur- } \\
\text { chased }\end{array}$ & Total & $\begin{array}{l}\text { Ground } \\
\text { water }\end{array}$ & $\begin{array}{c}\text { Surface } \\
\text { water }\end{array}$ & Total & & & \\
\hline 1946 & 0 & - & $\cdots$ & 0 & 0 & -- & 0 & 0 & 0 & 0 \\
\hline 1947 & 600.0 & -- & -- & 0 & 0 & -- & 0 & 0 & 0 & 500.0 \\
\hline 1948 & 26.0 & -- & -- & 0 & 0 & -- & 0 & 0 & 0 & 150.0 \\
\hline 1949 & 245.0 & -- & -- & 0 & 0 & -- & 0 & 0 & 0 & $1,820.0$ \\
\hline 1950 & 600.0 & -- & - & 0 & 0 & -- & 0 & 0 & 0 & 356.0 \\
\hline 1951 & 613.0 & -- & -- & 0 & 0 & -- & 0 & 45.0 & 0 & 25.0 \\
\hline 1952 & 600.0 & -- & -- & 0 & 0 & -- & 0 & 0 & $\mathbf{0}$ & $1,752.0$ \\
\hline 1953 & $1,362.0$ & -- & -- & 0 & 0 & -- & 0 & 183.0 & 0 & 426.0 \\
\hline 1954 & 8.0 & -- & -- & 0 & 0 & -- & 0 & 0 & 0 & $1,065.0$ \\
\hline 1955 & 570.0 & -- & -- & 0 & 0 & -- & 0 & 0 & 0 & $1,731.0$ \\
\hline 1956 & 358.0 & -- & -- & 0 & 0 & -- & 0 & $1,349.0$ & 0 & $1,640.0$ \\
\hline 1957 & 744.0 & -- & -- & 0 & 0 & 579.2 & 579.2 & 752.0 & 0 & 476.0 \\
\hline 1958 & 140.0 & -- & $\cdots$ & 0 & 0 & 579.2 & 579.2 & 16.0 & 9.0 & 651.0 \\
\hline 1959 & 425.0 & -- & -. & 0 & 0 & 579.2 & 579.2 & 575.0 & 100.0 & 73.0 \\
\hline 1960 & 471.0 & -- & -- & 0 & 0 & 579.2 & 579.2 & $1,251,0$ & 0 & $1,329.0$ \\
\hline 1961 & 161.0 & -- & -- & 0 & 0 & 579.2 & 579.2 & $1,317.0$ & 0 & $1,672.0$ \\
\hline 1962 & 168.0 & -. & -- & 0 & 0 & 579.2 & 579.2 & 0 & 0 & 669.0 \\
\hline 1963 & 794.0 & -- & -- & 0 & 0 & 579.2 & 579.2 & 656.0 & 0 & 594.0 \\
\hline 1964 & 573.0 & -- & -. & 0 & 0 & 579.2 & 579.2 & $1,158.0$ & 406.0 & $1,663.0$ \\
\hline 1965 & $1,729.0$ & - & -- & 0 & 0 & 579.2 & 579.2 & $2,630.0$ & 418.0 & $1,614.0$ \\
\hline 1966 & 1.0 & -- & - & 0 & 0 & 438.2 & 438.2 & 75.0 & $1,553.0$ & 607.0 \\
\hline 1967 & 584.0 & -- & -- & 0 & 0 & 502.9 & 502.9 & $2,175.0$ & $1,000.0$ & $2,003.0$ \\
\hline 1968 & $1,409.0$ & -- & -- & 0 & 0 & -- & 0 & $3,281.0$ & 60.0 & $1,512.0$ \\
\hline 1969 & 0 & -- & -- & 0 & 0 & -- & 0 & 620.0 & 462.0 & $1,571.0$ \\
\hline 1970 & $1,287.0$ & -- & -- & 0 & 0 & -- & 0 & $1,223.0$ & 150.0 & $1,706.0$ \\
\hline 1971 & $1,287.0$ & -- & -- & 0 & 0 & 272.0 & 272.0 & $1,673.0$ & 266.0 & $1,791.0$ \\
\hline 1972 & 0 & -- & -- & 0 & 0 & 276.0 & 276.0 & $3,616.0$ & 21.0 & $1,189.0$ \\
\hline 1973 & 863.0 & -. & - & 0 & 0 & 416.3 & 416.3 & $2,408.0$ & 207.0 & 704.0 \\
\hline 1974 & 863.0 & -. & -- & 0 & 0 & 457.2 & 457.2 & $2,556.0$ & 199.0 & $1,612.0$ \\
\hline 1975 & 863.0 & .- & $\cdots$ & 0 & 0 & 337.5 & 337.5 & $2,737.0$ & 193.0 & $1,594.0$ \\
\hline 1976 & 0 & .- & 0 & 0 & 0 & $\cdots$ & 0 & $2,638.0$ & 150.0 & $1,754.0$ \\
\hline 1977 & 863.0 & .. & 0 & 0 & 0 & -- & 0 & $2,863.0$ & 202.0 & $1,756.0$ \\
\hline 1978 & 862.0 & - & 0 & 0 & 0 & -- & 0 & $2,566.0$ & 211.0 & $3,551.0$ \\
\hline 1979 & 862.0 & .. & 0 & 0 & 550.0 & 669.0 & $1,219.0$ & $2,566.4$ & 273.0 & $1,827.0$ \\
\hline 1980 & 862.0 & -. & 0 & 0 & 0 & 615.6 & 615.6 & $2,174.6$ & 303.5 & $1,779.0$ \\
\hline 1981 & 862.5 & -- & 522.0 & 522.0 & 0 & 475.6 & 475.6 & $2,020.0$ & 276.3 & $1,629.6$ \\
\hline 1982 & 862.5 & -- & 0 & 0 & 0 & 288.4 & 288.4 & $2,706.0$ & 316.7 & $1,525.0$ \\
\hline 1983 & 860.0 & $-\cdot$ & 1.0 & 1.0 & 0 & 220.3 & 220.3 & $2,400.0$ & 565.7 & $1,265.4$ \\
\hline 1984 & 862.5 & -- & 455.0 & 455.0 & 0 & 204.1 & 204.1 & $3,640.0$ & 34.8 & $1,750.8$ \\
\hline 1985 & 862.5 & - & 0 & 0 & 0 & 191.8 & 191.8 & $3,399.0$ & 560.4 & $1,636.9$ \\
\hline 1986 & 862.5 & -- & 0 & 0 & 0 & 172.8 & 172.8 & $3,560.6$ & 552.5 & 0 \\
\hline 1987 & 862.5 & -- & 0 & 0 & 0 & 175.5 & 175.5 & $3,633.2$ & 313.1 & $1,339.8$ \\
\hline 1988 & 0 & -- & 177.0 & 177.0 & 0 & 170.3 & 170.3 & $2,050.0$ & 0 & 0 \\
\hline 1989 & 0 & - & 0 & 0 & 0 & 180.7 & 180.7 & 0 & 278.3 & 0 \\
\hline 1990 & 0 & -. & 0 & 0 & 0 & 168.2 & 168.2 & 0 & 0 & $1,365.1$ \\
\hline 1991 & 0 & $1,074.0$ & $-1,074.0$ & 0 & 0 & -. & 0 & 0 & 397.4 & $1,248.3$ \\
\hline 1992 & 0 & -- & 0 & 0 & 0 & -- & 0 & 0 & 0 & 0 \\
\hline
\end{tabular}


Table 19. Water-use information for self-suppiied water users in Antelope Valley by water-supply sources, 1946-92--Continued

\begin{tabular}{|c|c|c|c|c|c|c|c|c|}
\hline \multirow{2}{*}{ Year } & \multirow{2}{*}{ 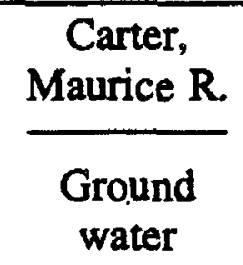 } & \multirow{2}{*}{$\begin{array}{c}\begin{array}{c}\text { Castronova, } \\
\text { Daniel }\end{array} \\
\text { Purchased }\end{array}$} & \multirow{2}{*}{$\begin{array}{c}\begin{array}{c}\text { Caton, Robert } \\
\text { and Richard }\end{array} \\
\begin{array}{c}\text { Ground } \\
\text { water }\end{array}\end{array}$} & \multirow{2}{*}{$\begin{array}{c}\text { Christoff, } \\
\text { Chris A. } \\
\begin{array}{c}\text { Ground } \\
\text { water }\end{array}\end{array}$} & \multirow{2}{*}{ 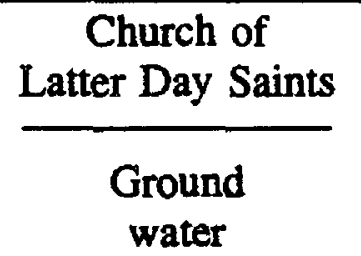 } & \multirow{2}{*}{$\begin{array}{c}\begin{array}{c}\text { Circle JM } \\
\text { Ranch }\end{array} \\
\begin{array}{c}\text { Ground } \\
\text { water }\end{array}\end{array}$} & \multirow{2}{*}{$\begin{array}{c}\begin{array}{c}\text { City } \\
\text { Ranch }\end{array} \\
\text { Purchased }\end{array}$} & \multirow{2}{*}{$\begin{array}{c}\begin{array}{c}\text { Clark, } \\
\text { Dick }\end{array} \\
\text { Purchased }\end{array}$} \\
\hline & & & & & & & & \\
\hline 1946 & 0 & -- & 0 & $\overline{0}$ & $\overline{0}$ & 0 & -- & -. \\
\hline 1947 & 0 & -- & 0 & 0 & 0 & 0 & -- & -- \\
\hline 1948 & 0 & -- & 960 & 0 & 0 & 0 & -- & .- \\
\hline 1949 & 0 & .. & 7.0 & 0 & 0 & 0 & -- & -. \\
\hline 1950 & 0 & -- & 729.0 & 0 & 0 & 270.0 & -- & -- \\
\hline 1951 & 0 & .- & 786.0 & 0 & 85.0 & 270.0 & .- & -- \\
\hline 1952 & 0 & -- & 541.0 & 0 & 85.0 & 270.0 & .. & -- \\
\hline 1953 & $1,140.0$ & .- & 317.0 & 0 & 550.0 & 313.0 & .- & .- \\
\hline 1954 & 0 & -- & 154.0 & 0 & 662.0 & 410.0 & -- & -. \\
\hline 1955 & 100 & -- & 657.0 & 0 & 85.0 & 270.0 & -- & -- \\
\hline 1956 & 100 & -- & 463.0 & 0 & 85.0 & 270.0 & -- & .- \\
\hline 1957 & $1,278.0$ & -- & 968.0 & 0 & 85.0 & 270.0 & -- & -- \\
\hline 1958 & 0 & -- & 572.0 & 0 & 80.0 & 268.0 & -- & -- \\
\hline 1959 & 0 & $\ldots$ & 106.0 & 0 & 56.0 & 270.0 & .- & .- \\
\hline 1960 & 0 & -- & $1,212.0$ & 0 & 38.0 & 270.0 & -- & -- \\
\hline 1961 & 0 & -. & 14.0 & 0 & 64.0 & 612.0 & .- & .- \\
\hline 1962 & 0 & $\ldots$ & 0 & 0 & 300.0 & $1,080.0$ & $\ldots$ & -. \\
\hline 1963 & 63.0 & -. & 478.0 & 0 & 97.0 & $1,080.0$ & -- & -- \\
\hline 1964 & 0 & -- & 625.0 & 0 & 97.0 & $1,080.0$ & .. & -- \\
\hline 1965 & 0 & -. & $1,009.0$ & 0 & 97.0 & $1,080.0$ & .- & -. \\
\hline 1966 & 0 & -- & 917.0 & 0 & 100.0 & $1,080.0$ & -- & -- \\
\hline 1967 & 691.0 & -. & 209.0 & 0 & 117.0 & $1,080.0$ & .- & -- \\
\hline 1968 & 67.0 & -- & 860.0 & 0 & 125.0 & 297.0 & -- & -- \\
\hline 1969 & 0 & -. & $1,276.0$ & 10 & 62.0 & $1,080.0$ & .. & -. \\
\hline 1970 & 0 & -- & 264.0 & 0 & 90.0 & $1,080.0$ & -- & .. \\
\hline 1971 & 0 & .- & 250.0 & 0 & 90.0 & $1,080.0$ & .- & -. \\
\hline 1972 & 0 & -- & 0 & 0 & 0 & 446.0 & -- & -- \\
\hline 1973 & 0 & .- & 0 & 905.0 & 125.0 & $1,050.0$ & -- & -- \\
\hline 1974 & 0 & -. & 100.0 & 935.0 & 125.0 & $1,050.0$ & .- & -- \\
\hline 1975 & 0 & -. & 120.0 & 904.0 & 0 & $1,050.0$ & -- & -- \\
\hline 1976 & 0 & 0 & 130.0 & 936.0 & 10.0 & $1,050.0$ & 405.0 & 0 \\
\hline 1977 & 0 & 0 & 140.0 & 905.0 & 300.0 & $1,050.0$ & 997.0 & 0 \\
\hline 1978 & 0 & 0 & 110.0 & 962.0 & 300.0 & 991.0 & 934.0 & 0 \\
\hline 1979 & 0 & 0 & 0 & 990.0 & 300.0 & 0 & 930.0 & 0 \\
\hline 1980 & 0 & 0 & 0 & $1,193.0$ & 360.0 & 0 & 655.0 & 0 \\
\hline 1981 & 0 & 0 & 0 & 954.0 & 360.0 & 0 & 966.0 & 0 \\
\hline 1982 & 0 & 0 & 0 & 328.0 & 180.0 & 0 & 8.0 & 0 \\
\hline 1983 & 0 & 0 & 0 & 0 & 200.0 & 0 & 20.0 & 0 \\
\hline 1984 & 0 & 0 & 0 & 0 & 200.0 & 0 & 2.0 & 0 \\
\hline 1985 & 0 & 0 & 0 & 0 & 135.0 & 0 & 218.0 & 0 \\
\hline 1986 & 0 & 0 & 0 & 75.0 & 150.0 & 0 & 0 & 0 \\
\hline 1987 & 0 & 0 & 0 & 77.0 & 150.0 & 0 & 0 & 0 \\
\hline 1988 & 0 & 0 & 0 & 0 & 0 & 0 & 0 & 0 \\
\hline 1989 & 0 & 2.0 & 0 & 129.0 & 150.0 & 0 & 0 & 0 \\
\hline 1990 & 0 & 7.0 & 0 & 121.0 & 150.0 & 0 & 0 & 4.0 \\
\hline 1991 & 0 & 7.0 & 0 & 131.0 & 150.0 & 0 & 0 & 6.0 \\
\hline 1992 & 0 & 7.0 & 0 & 0 & 0 & 0 & 0 & 6.0 \\
\hline
\end{tabular}


Table 19. Water-use information for self-supplied water users in Antelope Valley by water-supply sources, 1946-92--Continued

\begin{tabular}{|c|c|c|c|c|c|c|c|}
\hline \multirow{2}{*}{ Year } & $\begin{array}{c}\text { Clayton, } \\
\text { Richard M. }\end{array}$ & $\begin{array}{l}\text { Cole, J.G., } \\
\text { and Sons }\end{array}$ & $\begin{array}{c}\text { Coor-Pender, } \\
\text { R.L. and Ruth B. }\end{array}$ & $\begin{array}{l}\text { Corpus, Cenon } \\
\text { and Regina }\end{array}$ & $\begin{array}{l}\text { Davis, } \\
\text { Shelton }\end{array}$ & $\begin{array}{c}\text { Delia, } \\
\text { Joseph E. }\end{array}$ & $\begin{array}{l}\text { Derosier, Lionel P. } \\
\text { and Patricia }\end{array}$ \\
\hline & $\begin{array}{c}\text { Ground } \\
\text { water }\end{array}$ & $\begin{array}{l}\text { Ground } \\
\text { water }\end{array}$ & $\begin{array}{c}\text { Ground } \\
\text { water }\end{array}$ & $\begin{array}{l}\text { Ground } \\
\text { water }\end{array}$ & $\begin{array}{l}\text { Ground } \\
\text { water }\end{array}$ & $\begin{array}{l}\text { Ground } \\
\text { water }\end{array}$ & $\begin{array}{c}\text { Ground } \\
\text { water }\end{array}$ \\
\hline 1946 & 0 & 0 & 0 & 0 & 0 & 0 & 0 \\
\hline 1947 & 0 & 784.0 & 0 & 548.0 & 0 & 239.0 & 0 \\
\hline 1948 & 0 & 420.0 & 0 & 548.0 & 0 & 239.0 & 0 \\
\hline 1949 & 0 & 503.0 & 0 & 440.0 & 0 & 239.0 & 0 \\
\hline 1950 & 0 & 780.0 & 0 & 548.0 & 0 & 239.0 & 0 \\
\hline 1951 & 0 & 950.0 & 0 & 388.0 & 0 & 876.0 & 0 \\
\hline 1952 & 0 & $1,470.0$ & 0 & 548.0 & 0 & 239.0 & 0 \\
\hline 1953 & 0 & 965.0 & 0 & $1,498.0$ & 0 & 239.0 & 0 \\
\hline 1954 & 0 & 272.0 & 0 & $1,120.0$ & 0 & 90.0 & 0 \\
\hline 1955 & 0 & $1,125.0$ & 0 & 548.0 & 0 & 239.0 & 0 \\
\hline 1956 & 0 & 844.0 & 0 & 367.0 & 0 & 387.0 & 0 \\
\hline 1957 & 0 & 85.0 & 0 & 480.0 & 0 & 239.0 & 0 \\
\hline 1958 & 0 & 128.0 & 0 & 480.0 & 0 & 239.0 & 0 \\
\hline 1959 & 0 & 700.0 & 0 & .480 .0 & 0 & 0 & 0 \\
\hline 1960 & 0 & $1,492.0$ & 0 & 480.0 & $1,307.0$ & 120.0 & 0 \\
\hline 1961 & 0 & $1,475.0$ & 0 & 0 & 800.0 & 120.0 & 0 \\
\hline 1962 & 0 & $1,496.0$ & 0 & $1,919.0$ & $1,168.0$ & 450.0 & 0 \\
\hline 1963 & 0 & 460.0 & 0 & 400.0 & 674.0 & 0 & 0 \\
\hline 1964 & 0 & $1,172.0$ & 0 & 480.0 & 674.0 & 0 & 0 \\
\hline 1965 & 0 & 700.0 & 0 & 480.0 & $13,000.0$ & 0 & 0 \\
\hline 1966 & 0 & 79.0 & 0 & 0 & $1,167.0$ & 525.0 & 0 \\
\hline 1967 & 0 & 660.0 & 8.0 & 480.0 & $1,167.0$ & 89.0 & 0 \\
\hline 1968 & 0 & $1,235.0$ & 10.0 & 480.0 & 952.0 & $1,690.0$ & 0 \\
\hline 1969 & 0 & $1,200.0$ & 18.0 & 480.0 & 907.0 & 14.0 & 0 \\
\hline 1970 & 0 & $1,175.0$ & 20.0 & 480.0 & 831.0 & 0 & 0 \\
\hline 1971 & 0 & 500.0 & 14.0 & 480.0 & $1,002.0$ & $1,114.0$ & 0 \\
\hline 1972 & 0 & 120.0 & 46.0 & 0 & 214.0 & 0 & 0 \\
\hline 1973 & 0 & 420.0 & 30.0 & 480.0 & 995.0 & 646.0 & 0 \\
\hline 1974 & 0 & 410.0 & 33.0 & 400.0 & 540.0 & 565.0 & 0 \\
\hline 1975 & 0 & 400.0 & 36.0 & 480.0 & 976.0 & 400.0 & 0 \\
\hline 1976 & 0 & 380.0 & 0 & 480.0 & 955.0 & 636.0 & 0 \\
\hline 1977 & 0 & 950.0 & 33.0 & 480.0 & 830.0 & 636.0 & 0 \\
\hline 1978 & 0 & 900.0 & 37.0 & 180.0 & 893.0 & 2.0 & 0 \\
\hline 1979 & 3.1 & 400.0 & 0 & 935.3 & 760.0 & 3.0 & 0 \\
\hline 1980 & 2.3 & 0 & 0 & 0 & 960.0 & 0 & 0 \\
\hline 1981 & 2.3 & 0 & 0 & 0 & 0 & 0 & 0 \\
\hline 1982 & 2.3 & 0 & 0 & 0 & 0 & 0 & 0 \\
\hline 1983 & 2.3 & 0 & 0 & 0 & 0 & .7 & 0 \\
\hline 1984 & 2.3 & 0 & 0 & 0 & 0 & 0 & 0 \\
\hline 1985 & 2.3 & 0 & 0 & 0 & 0 & 1.7 & 0 \\
\hline 1986 & 2.3 & 0 & 0 & 0 & 0 & 2.2 & 0 \\
\hline 1987 & 2.3 & 0 & 0 & 0 & 0 & 4.5 & 0 \\
\hline 1988 & 2.3 & 0 & 0 & 0 & 0 & 0 & 1.5 \\
\hline 1989 & 0 & 0 & 0 & 0 & 0 & 2.2 & 0 \\
\hline 1990 & 0 & 0 & 0 & .2 & 0 & 0 & 0 \\
\hline 1991 & 1.5 & 0 & 0 & 0 & 0 & 32.4 & 0 \\
\hline 1992 & 0 & 0 & 0 & 0 & 0 & 0 & 0 \\
\hline
\end{tabular}


Table 19. Water-use information for self-supplied water users in Antelope Valley by water-supply sources, 1946-92-Continued

\begin{tabular}{|c|c|c|c|c|c|c|c|c|}
\hline \multirow{2}{*}{ Year } & \multirow{2}{*}{$\begin{array}{l}\text { Derrick, } \\
\text { Olin E. } \\
\begin{array}{c}\text { Ground } \\
\text { water }\end{array}\end{array}$} & \multirow{2}{*}{$\begin{array}{c}\begin{array}{c}\text { Dustin, } \\
\text { Doug }\end{array} \\
\frac{\begin{array}{c}\text { Ground } \\
\text { water }\end{array}}{}\end{array}$} & \multirow{2}{*}{ 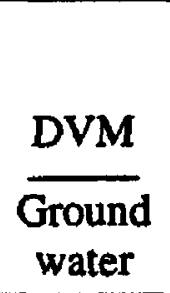 } & \multirow{2}{*}{$\begin{array}{c}\begin{array}{c}\text { Elliott, } \\
\text { Jay E., } \\
\text { and others }\end{array} \\
\begin{array}{c}\text { Surface } \\
\text { water }\end{array}\end{array}$} & \multirow{2}{*}{$\begin{array}{c}\begin{array}{c}\text { EPIC/Smith } \\
\text { Development } \\
\text { Company }\end{array} \\
\begin{array}{c}\text { Ground } \\
\text { water }\end{array}\end{array}$} & \multirow{2}{*}{$\frac{\text { Fabe }}{\text { Purchased }}$} & \multirow{2}{*}{$\begin{array}{c}\begin{array}{c}\text { Fattaminia Family } \\
\text { Trust, and others }\end{array} \\
\begin{array}{c}\text { Surface } \\
\text { water }\end{array}\end{array}$} & \multirow{2}{*}{$\begin{array}{c}\begin{array}{c}\text { Freund, } \\
\text { Jerry }\end{array} \\
\text { Purchased }\end{array}$} \\
\hline & & & & & & & & \\
\hline 1946 & 0 & 0 & 0 & 0.2 & 0 & -- & -- & -- \\
\hline 1947 & 0 & 240.0 & 0 & .2 & 0 & -- & -- & -- \\
\hline 1948 & 0 & 895.0 & 300.0 & .6 & 0 & -- & -- & -- \\
\hline 1949 & 0 & 240.0 & 490.0 & .6 & 0 & -- & -- & -- \\
\hline 1950 & 0 & 240.0 & $1,200.0$ & .5 & 0 & -- & -- & -- \\
\hline 1951 & 515.0 & 240.0 & 480.0 & .5 & 72.0 & -- & -- & -- \\
\hline 1952 & 257.0 & 28.0 & $1,440.0$ & .5 & 30.0 & -- & -- & -- \\
\hline 1953 & 70.0 & 240.0 & $1,970.0$ & .5 & 190.0 & -- & -- & -- \\
\hline 1954 & 0 & 55.0 & $1,780.0$ & .5 & 56.0 & -- & -- & -- \\
\hline 1955 & 520.0 & 185.0 & $1,780.0$ & .5 & 72.0 & -- & -- & -- \\
\hline 1956 & 520.0 & 171.0 & $1,800.0$ & .5 & 480.0 & -. & -- & -- \\
\hline 1957 & 337.0 & 212.0 & 738.0 & .5 & 201.0 & -. & -- & -- \\
\hline 1958 & 520.0 & 180.0 & $1,038.0$ & .5 & 806.0 & .- & -- & -- \\
\hline 1959 & 0 & 195.0 & 287.0 & .5 & 25.0 & -- & -- & -- \\
\hline 1960 & 290.0 & 248.0 & $1,925.0$ & .5 & 76.0 & -- & -- & -- \\
\hline 1961 & $1,089.0$ & 203.0 & $1,485.0$ & .5 & 100.0 & -- & -- & -- \\
\hline 1962 & 903.0 & 232.0 & $1,450.0$ & .5 & 13.0 & -- & -- & -- \\
\hline 1963 & 237.0 & 228.0 & 826.0 & .4 & 37.0 & -- & $1,498.8$ & -- \\
\hline 1964 & 903.0 & 234.0 & $1,100.0$ & .4 & 35.0 & -- & $1,498.8$ & -- \\
\hline 1965 & 560.0 & 234.0 & $1,925.0$ & .4 & 8.0 & -- & $1,498.8$ & -- \\
\hline 1966 & $15,985.0$ & 0 & $1,383.0$ & .5 & 0 & -- & -- & -- \\
\hline 1967 & 0 & 234.0 & $1,200.0$ & .5 & 0 & -- & -- & -- \\
\hline 1968 & 299.0 & 283.0 & $1,594.0$ & .5 & 0 & -- & -- & -- \\
\hline 1969 & 201.0 & 308.0 & $2,400.0$ & 1.6 & 0 & -. & -- & -- \\
\hline 1970 & $1,000.0$ & 234.0 & $2,400.0$ & 1.6 & 38.0 & -- & -- & -- \\
\hline 1971 & 0 & 0 & 0 & 1.6 & 41.0 & -- & .. & -- \\
\hline 1972 & 6.0 & 57.0 & $1,153.0$ & -- & 628.0 & -- & -- & -- \\
\hline 1973 & 0 & 0 & 0 & -- & 45.0 & .- & -- & .. \\
\hline 1974 & 0 & 0 & 0 & -- & 36.0 & -- & -- & -- \\
\hline 1975 & $1,000.0$ & 0 & 0 & -- & 0 & -- & -- & -- \\
\hline 1976 & $1,000.0$ & 0 & 0 & -- & 0 & 0 & -- & 0 \\
\hline 1977 & $1,200.0$ & 0 & 0 & -- & 0 & 0 & -- & 0 \\
\hline 1978 & 0 & 0 & 0 & -- & 0 & 196.0 & -- & 0 \\
\hline 1979 & 0 & 0 & 0 & 1.6 & 30.0 & 408.0 & -- & 0 \\
\hline 1980 & 0 & 0 & 0 & 1.6 & 10.0 & 410 & $1,809.9$ & 0 \\
\hline 1981 & 0 & 0 & 0 & 1.6 & 75.0 & 534.0 & $1,809.9$ & 0 \\
\hline 1982 & 0 & 0 & 0 & -- & 75.0 & 536.0 & $1,809.9$ & 0 \\
\hline 1983 & 0 & 0 & 0 & -- & 75.0 & 0 & -- & 0 \\
\hline 1984 & 0 & 0 & 0 & -- & 0 & 405.0 & -- & 0 \\
\hline 1985 & 0 & 0 & 0 & -- & 0 & 0 & -- & 0 \\
\hline 1986 & 0 & 0 & 0 & -- & 75.0 & 0 & -- & 0 \\
\hline 1987 & 0 & 0 & 0 & -- & 75.0 & 0 & -- & 4.0 \\
\hline 1988 & 0 & 0 & 0 & -- & 0 & 0 & -- & 9.0 \\
\hline 1989 & 0 & 0 & 0 & -- & 0 & 0 & -- & 14.0 \\
\hline 1990 & 0 & 0 & 0 & -. & 0 & 0 & -- & 6.0 \\
\hline 1991 & 0 & 0 & 0 & -- & 0 & 0 & -- & 7.0 \\
\hline 1992 & 0 & 0 & 0 & -- & 0 & 0 & -- & 1.0 \\
\hline
\end{tabular}


Table 19. Water-use information for seif-supplied water users in Antelope Vailey by water-supply sources, 1946-92-Continued

\begin{tabular}{|c|c|c|c|c|c|c|c|}
\hline \multirow{2}{*}{ Year } & $\begin{array}{l}\text { Frisella, } \\
\text { Josef }\end{array}$ & Fuson & $\begin{array}{l}\text { Gagik, Galstian, } \\
\text { Trustee }\end{array}$ & $\begin{array}{c}\text { Gallin, Leo } \\
\text { and Ruth Morton }\end{array}$ & $\begin{array}{c}\text { Gateway Triangle } \\
\text { Properties }\end{array}$ & $\begin{array}{c}\text { Gaviota } \\
\text { Incorporated }\end{array}$ & $\begin{array}{l}\text { Graham, } \\
\text { John, } \\
\text { and others }\end{array}$ \\
\hline & $\begin{array}{l}\text { Ground } \\
\text { water }\end{array}$ & Purchased & $\begin{array}{l}\text { Ground } \\
\text { water }\end{array}$ & $\begin{array}{l}\text { Ground } \\
\text { water }\end{array}$ & $\begin{array}{l}\text { Surface } \\
\text { water }\end{array}$ & $\begin{array}{c}\text { Surface } \\
\text { water }\end{array}$ & $\begin{array}{c}\text { Surface } \\
\text { water }\end{array}$ \\
\hline 1946 & 0 & - & 0 & 0 & 39.1 & 11.2 & - \\
\hline 1947 & 0 & -- & 0 & 0 & 39.1 & 11.2 & -- \\
\hline 1948 & 0 & -- & 0 & 0 & 39.1 & 11.2 & -- \\
\hline 1949 & 0 & -- & 250.0 & 0 & 39.1 & 11.2 & -- \\
\hline 1950 & 0 & -. & 0 & 0 & 39.1 & 11.2 & -- \\
\hline 1951 & 0. & -- & 0 & 480.0 & 39.1 & 11.2 & -. \\
\hline 1952 & 0 & -- & 606.0 & 0 & 39.1 & 11.2 & -. \\
\hline 1953 & 0 & -- & 70.0 & $1,288.0$ & 39.1 & 11.2 & -- \\
\hline 1954 & 0 & -- & 948.0 & $1,250.0$ & 39.1 & 11.2 & -. \\
\hline 1955 & 0 & -- & 0 & $1,200.0$ & 39.1 & 11.2 & .. \\
\hline 1956 & 0 & -- & 0 & $1,200.0$ & 39.1 & 11.2 & -- \\
\hline 1957 & 0 & -- & 701.0 & 156.0 & 39.1 & 11.2 & -- \\
\hline 1958 & 0 & -- & 77.0 & 0 & 39.1 & 11.2 & -- \\
\hline 1959 & 0 & -- & 36.0 & 0 & 39.1 & 11.2 & -- \\
\hline 1960 & 0 & -- & $1,170.0$ & 6.0 & 39.1 & 11.2 & -- \\
\hline 1961 & 0 & -- & $1,170.0$ & 0 & 39.1 & 11.2 & -- \\
\hline 1962 & 0 & -- & 433.0 & 0 & 39.1 & 14.5 & -- \\
\hline 1963 & 0 & -- & 377.0 & 0 & 39.1 & 14.5 & -- \\
\hline 1964 & 0 & -- & 120.0 & 360.0 & 39.1 & 14.5 & -- \\
\hline 1965 & 0 & -- & $1,170.0$ & 360.0 & 39.1 & 11.2 & 5.1 \\
\hline 1966 & 0 & -- & $1,170.0$ & 0 & 39.1 & 11.2 & 5.1 \\
\hline 1967 & 0 & -- & $1,170.0$ & 851.0 & 39.1 & 11.2 & 5.1 \\
\hline 1968 & 0 & -- & $1,170.0$ & $1,575.0$ & 39.1 & -- & 5.1 \\
\hline 1969 & 0 & -- & $1,170.0$ & 0 & 39.1 & -- & 5.1 \\
\hline 1970 & 0 & -- & $1,300.0$ & 0 & 39.1 & -- & 5.1 \\
\hline 1971 & 0 & - & $1,300.0$ & 0 & 39.1 & -- & 5.1 \\
\hline 1972 & 0 & -- & $1,122.0$ & 0 & 39.1 & -- & 5.1 \\
\hline 1973 & 0 & -- & $1,300.0$ & 0 & 39.1 & -- & 5.1 \\
\hline 1974 & 0 & -- & $1,300.0$ & 0 & 39.1 & -. & 5.1 \\
\hline 1975 & 0 & -- & $1,000.0$ & 0 & 39.1 & -- & 5.1 \\
\hline 1976 & 0 & $8,814.0$ & $1,000.0$ & 0 & 39.1 & -- & 5.1 \\
\hline 1977 & 0 & $5,760.0$ & $1,000.0$ & 0 & 39.1 & -- & 5.1 \\
\hline 1978 & 0 & $5,569.0$ & 950.0 & 0 & 39.1 & -. & 5.1 \\
\hline 1979 & 0 & $5,467.0$ & 950.0 & 0 & 39.1 & -- & 5.1 \\
\hline 1980 & 0 & $6,527.0$ & 950.0 & 0 & 39.1 & -- & -- \\
\hline 1981 & 0 & $6,985.0$ & $1,000.0$ & 0 & 39.1 & 11.2 & 1.1 \\
\hline 1982 & 0 & $2,742.0$ & $1,100.0$ & 0 & 39.1 & 11.2 & 1.1 \\
\hline 1983 & 0 & 8.0 & $1,100.0$ & 0 & 39.1 & 11.2 & 1.1 \\
\hline 1984 & 0 & 0 & 708.0 & 0 & 39.1 & 10.2 & 5.1 \\
\hline 1985 & 0 & 0 & 708.0 & 0 & 39.1 & 10.2 & 5.1 \\
\hline 1986 & 0 & 0 & 740.0 & 0 & 39.1 & 10.2 & 5.1 \\
\hline 1987 & 0 & 0 & 860.0 & 0 & -- & 11.2 & 5.1 \\
\hline 1988 & 0 & 0 & 740.0 & 0 & -- & 11.2 & 5.1 \\
\hline 1989 & 0 & 0 & $1,050.0$ & 0 & -- & 11.2 & 5.1 \\
\hline 1990 & 0 & 0 & 960.0 & 0 & -- & 11.2 & -- \\
\hline 1991 & 11.4 & $-5,065.0$ & 0 & 0 & -- & -- & -- \\
\hline 1992 & 0 & 0 & 0 & 0 & -- & -- & -- \\
\hline
\end{tabular}


Table 19. Water-use information for self-supplied water users in Antelope Valley by. water-supply sources, 1946-92--Continued

\begin{tabular}{|c|c|c|c|c|c|c|c|c|c|}
\hline Year & $\begin{array}{c}\begin{array}{c}\text { Grainger, } \\
\text { Donald L. }\end{array} \\
\begin{array}{c}\text { Ground } \\
\text { water }\end{array}\end{array}$ & $\begin{array}{c}\begin{array}{c}\text { Griffen, } \\
\text { Laura }\end{array} \\
\begin{array}{c}\text { Ground } \\
\text { water }\end{array}\end{array}$ & $\begin{array}{c}\begin{array}{c}\text { Groven, } \\
\text { Dennis L. } \\
\begin{array}{c}\text { Ground } \\
\text { water }\end{array}\end{array}\end{array}$ & $\begin{array}{c}\text { Harter, } \\
\text { Leo A. } \\
\begin{array}{c}\text { Ground } \\
\text { water }\end{array}\end{array}$ & $\begin{array}{c}\begin{array}{c}\text { Hathaway } \\
\text { Ranch }\end{array} \\
\begin{array}{c}\text { Ground } \\
\text { water }\end{array}\end{array}$ & $\begin{array}{c}\text { Healy } \\
\text { Enterprises } \\
\text { Incorporated }\end{array}$ & $\begin{array}{c}\text { Hee, } \\
\text { Thorton, } \\
\text { and Patti } \\
\begin{array}{c}\text { Ground } \\
\text { water }\end{array}\end{array}$ & $\begin{array}{c}\begin{array}{c}\text { Hicks, } \\
\text { David R. }\end{array} \\
\begin{array}{c}\text { Ground } \\
\text { water }\end{array}\end{array}$ & $\begin{array}{c}\begin{array}{c}\text { Heiner, } \\
\text { Lucius B. }\end{array} \\
\begin{array}{c}\text { Ground } \\
\text { water }\end{array}\end{array}$ \\
\hline 1946 & 0 & 0 & 0 & 0 & 0 & 0 & 0 & 0 & 0 \\
\hline 1947 & 0 & 0 & 0 & 0 & 0 & 0 & 0 & 0 & 0 \\
\hline 1948 & 0 & $1,820.0$ & 0 & 0 & 0 & 0 & 258.0 & 0 & 0 \\
\hline 1949 & 0 & 420.0 & 0 & 0 & 0 & 794.0 & 730.0 & 0 & 0 \\
\hline 1950 & 0 & $3,360.0$ & 0 & 0 & 0 & 0 & 0 & 0 & 0 \\
\hline 1951 & 0 & $3,360.0$ & 0 & 250.0 & 0 & 0 & 560.0 & 0 & 0 \\
\hline 1952 & 0 & $3,360.0$ & 0 & 500.0 & 0 & $1,560.0$ & 220.0 & 0 & 0 \\
\hline 1953 & 0 & 840.0 & 0 & 500.0 & 0 & 350.0 & 220.0 & 0 & 476.0 \\
\hline 1954 & 0 & $3,360.0$ & 0 & 500.0 & $1,304.0$ & 100.0 & 672.0 & 0 & 0 \\
\hline 1955 & 0 & $2,880.0$ & 0 & 500.0 & $1,304.0$ & 0 & 140.0 & 0 & 34.0 \\
\hline 1956 & 0 & $2,820.0$ & 0 & 550.0 & $1,304.0$ & 656.0 & 840.0 & 0 & 0 \\
\hline 1957 & 375.0 & 500.0 & 0 & 678.0 & $1,304.0$ & 278.0 & 84.0 & 0 & 39.0 \\
\hline 1958 & 375.0 & 150.0 & 0 & 630.0 & 548.0 & 19.0 & 84.0 & 0 & 42.0 \\
\hline 1959 & 0 & 420.0 & 500.0 & 650.0 & 228.0 & 491.0 & 270.0 & 0 & 3.0 \\
\hline 1960 & 0 & 420.0 & 500.0 & 650.0 & $1,304.0$ & 14.0 & 84.0 & 0 & 43.0 \\
\hline 1961 & 0 & 600.0 & 8.0 & 615.0 & $1,304.0$ & 575.0 & 900.0 & 0 & 200.0 \\
\hline 1962 & 0 & 480.0 & 20.0 & 762.0 & $1,304.0$ & 480.0 & 84.0 & 0 & 40.0 \\
\hline 1963 & 0 & 480.0 & $500.0^{\circ}$ & 490.0 & 0 & 3.0 & 84.0 & 0 & 40.0 \\
\hline 1964 & 882.0 & 550.0 & 500.0 & 28.0 & $2,443.0$ & 583.0 & 175.0 & 0 & 0 \\
\hline 1965 & $1,200.0$ & 420.0 & 500.0 & 650.0 & 651.0 & 0 & 84.0 & 0 & 35.0 \\
\hline 1966 & $1,155.0$ & 450.0 & 123.0 & 650.0 & $1,306.0$ & 0 & 84.0 & 0 & 35.0 \\
\hline 1967 & 419.0 & 444.0 & 20.0 & 618.0 & $1,920.0$ & 0 & 84.0 & 0 & 30.0 \\
\hline 1968 & 0 & 450.0 & 500.0 & 515.0 & 709.0 & 1 & 84.0 & 0 & 20.0 \\
\hline 1969 & 0 & 450.0 & 11.0 & 980.0 & $2,827.0$ & 0 & 84.0 & 0 & 20.0 \\
\hline 1970 & 0 & 450.0 & 0 & 430.0 & 754.0 & 0 & 84.0 & 0 & 15.0 \\
\hline 1971 & 0 & 450.0 & 500.0 & 20.0 & 803.0 & 0 & 84.0 & 0 & 15.0 \\
\hline 1972 & 0 & 0 & 465.0 & 12.0 & 401.0 & 0 & 0 & 0 & 499.0 \\
\hline 1973 & 0 & 450.0 & $2,250.0$ & 0 & 841.0 & 0 & 84.0 & 0 & 15.0 \\
\hline 1974 & 0 & 450.0 & 500.0 & 0 & 888.0 & 0 & 190.0 & 0 & 0 \\
\hline 1975 & 0 & 450.0 & 500.0 & 0 & 891.0 & 0 & 102.0 & 0 & 10.0 \\
\hline 1976 & 0 & 450.0 & 500.0 & 0 & 890.0 & 0 & 84.0 & 0 & 0 \\
\hline 1977 & 0 & 450.0 & 500.0 & 0 & 892.0 & 0 & 84.0 & .1 & 0 \\
\hline 1978 & 0 & 450.0 & 500.0 & 0 & 868.0 & 0 & 84.0 & .1 & 10.0 \\
\hline 1979 & 0 & 450.0 & 500.0 & 0 & 0 & 0 & 0 & .1 & 0 \\
\hline 1980 & 0 & 450.0 & 500.0 & 0 & 789.0 & 0 & 0 & .1 & 0 \\
\hline 1981 & 0 & 450.0 & 600.0 & 0 & 790.0 & 0 & 0 & .1 & 10.0 \\
\hline 1982 & 0 & 450.0 & 600.0 & 0 & 785.0 & 0 & 0 & .1 & 25.0 \\
\hline 1983 & 0 & 450.0 & 600.0 & 0 & 5.0 & 0 & 0 & .1 & 0 \\
\hline 1984 & 0 & 450.0 & 600.0 & 0 & 5.0 & 0 & 0 & .1 & 0 \\
\hline 1985 & 0 & 450.0 & 600.0 & 0 & 5.0 & 0 & 0 & .1 & 9.5 \\
\hline 1986 & 0 & 450.0 & 600.0 & 0 & 0 & 0 & 0 & .1 & 0 \\
\hline 1987 & 0 & 450.0 & 700.0 & 0 & 0 & 0 & 0 & .1 & 0 \\
\hline 1988 & 0 & 450.0 & 600.0 & 0 & 0 & 0 & 0 & .1 & 0 \\
\hline 1989 & 0 & 450.0 & 600.0 & 0 & 0 & 0 & 0 & 0 & 0 \\
\hline 1990 & 0 & 450.0 & 600.0 & 0 & 0 & 0 & 0 & 0 & 20.0 \\
\hline 1991 & 0 & 450.0 & 600.0 & 0 & 0 & 0 & 0 & 0 & 0 \\
\hline 1992 & 0 & 0 & 0 & 0 & 0 & 0 & 0 & 0 & 0 \\
\hline
\end{tabular}


Table 19. Water-use information for self-supplied water users in Antelope Valley by water-supply sources, 1946-92-Continued

\begin{tabular}{|c|c|c|c|c|c|c|c|c|c|c|c|}
\hline \multirow{2}{*}{ Year } & \multirow{2}{*}{$\frac{\begin{array}{c}\text { Hines, } \\
\text { Robert G. }\end{array}}{\begin{array}{c}\text { Ground } \\
\text { water }\end{array}}$} & \multirow{2}{*}{$\frac{\text { Hughes }}{\begin{array}{c}\text { Pur- } \\
\text { chased }\end{array}}$} & \multirow{2}{*}{$\begin{array}{c}\begin{array}{c}\text { Hughes } \\
\text { Development } \\
\text { Corporation }\end{array} \\
\begin{array}{c}\text { Pur- } \\
\text { chased }\end{array}\end{array}$} & \multirow{2}{*}{$\begin{array}{l}\begin{array}{c}\text { Hughes, } \\
\text { Rodger }\end{array} \\
\begin{array}{c}\text { Pur- } \\
\text { chased }\end{array}\end{array}$} & \multirow{2}{*}{$\frac{\begin{array}{c}\text { Iarussi, } \\
\text { Armando }\end{array}}{\begin{array}{c}\text { Pur- } \\
\text { chased }\end{array}}$} & \multirow{2}{*}{$\frac{\begin{array}{c}\text { Johnson, } \\
\text { Malachi S. }\end{array}}{\begin{array}{c}\text { Ground } \\
\text { water }\end{array}}$} & \multirow{2}{*}{$\begin{array}{c}\begin{array}{c}\text { Johnson, } \\
\text { Arch D. }\end{array} \\
\begin{array}{c}\text { Ground } \\
\text { water }\end{array}\end{array}$} & \multirow{2}{*}{$\frac{\begin{array}{c}\text { Kadivar, } \\
\text { Steve }\end{array}}{\begin{array}{c}\text { Ground } \\
\text { water }\end{array}}$} & \multicolumn{3}{|c|}{$\begin{array}{l}\text { Kaufman and Broad } \\
\text { Land Company }\end{array}$} \\
\hline & & & & & & & & & $\begin{array}{l}\text { Ground } \\
\text { water }\end{array}$ & $\begin{array}{l}\text { Pur- } \\
\text { chased }\end{array}$ & Total \\
\hline 1946 & 0 & -- & -- & -- & -. & 0 & 0 & 0 & 0 & -. & 0 \\
\hline 1947 & 268.0 & -- & .- & .- & .- & 0 & 0 & 0 & 0 & .- & 0 \\
\hline 1948 & 268.0 & -- & -- & -- & -- & 0 & 0 & 0 & 0 & -- & 0 \\
\hline 1949 & 480.0 & -- & -- & -- & .- & 0 & 0 & 0 & 0 & -- & 0 \\
\hline 1950 & 520.0 & -- & -. & -- & -- & 0 & 0 & 0 & 0 & -- & 0 \\
\hline 1951 & 569.0 & -- & -- & -- & -- & 0 & 0 & 0 & 0 & -- & 0 \\
\hline 1952 & 789.0 & .. & .. & -- & -- & 0 & 0 & 0 & 0 & -. & 0 \\
\hline 1953 & 643.0 & -. & -- & -- & -- & 0 & 0 & 0 & 0 & -- & 0 \\
\hline 1954 & 697.0 & - & .- & .. & -- & 0 & 0 & 0 & 0 & -- & 0 \\
\hline 1955 & 750.0 & $\ldots$ & -- & -- & -- & 0 & 0 & 0 & 0 & -- & 0 \\
\hline 1956 & 750.0 & $\ldots$ & -- & -- & -- & 0 & 0 & 0 & 0 & -- & 0 \\
\hline 1957 & 720.0 & -- & -- & -- & .- & 0 & 0 & 0 & 0 & -- & 0 \\
\hline 1958 & 712.0 & -- & -- & -- & -- & 0 & 0 & 0 & 0 & -- & 0 \\
\hline 1959 & 705.0 & -- & -- & -. & -- & 0 & 0 & 0 & 0 & -- & 0 \\
\hline 1960 & 733.0 & -- & -- & -- & .- & 0 & 0 & 0 & 0 & -- & 0 \\
\hline 1961 & 250.0 & -- & -- & -- & -- & 0 & 0 & 0 & 0 & -- & 0 \\
\hline 1962 & 707.0 & -. & .- & .- & .- & 0 & 0 & 0 & 0 & .- & 0 \\
\hline 1963 & 680.0 & -- & -- & -- & -- & 0 & 0 & 0 & 0 & -. & 0 \\
\hline 1964 & $1,264.0$ & -- & -- & .- & .. & 0 & 0 & 0 & 0 & -- & 0 \\
\hline 1965 & $1,320.0$ & -- & -- & -- & -- & 0 & 0 & 0 & 0 & -- & 0 \\
\hline 1966 & 500.0 & .. & .- & -- & -- & 0 & 0 & 0 & 0 & .- & 0 \\
\hline 1967 & 660.0 & -- & -- & -- & -- & 0 & 0 & $1,080.0$ & 0 & -- & 0 \\
\hline 1968 & 654.0 & -- & -- & -- & -. & 0 & 10.0 & $1,080.0$ & 0 & -- & 0 \\
\hline 1969 & 625.0 & -- & -- & -- & -- & 0 & 10.0 & $1,080.0$ & 0 & -- & 0 \\
\hline 1970 & 600.0 & -- & -- & -- & -- & 35.0 & 10.0 & $1,452.0$ & 0 & -- & 0 \\
\hline 1971 & $1,100.0$ & -- & .. & -- & -- & 0 & 10.0 & $1,452.0$ & 0 & -- & 0 \\
\hline 1972 & 0 & -- & -- & -- & -- & 654.0 & 10.0 & 0 & 0 & -- & 0 \\
\hline 1973 & $1,005.0$ & -- & -- & -- & -- & 10.0 & 10.0 & 0 & 0 & -- & 0 \\
\hline 1974 & 990.0 & -- & -- & $\therefore$ & -- & 10.0 & 10.0 & 0 & 0 & -- & 0 \\
\hline 1975 & $1,020.0$ & -- & -- & -- & -- & 0 & 10.0 & 540.0 & 0 & -- & 0 \\
\hline 1976 & $1,000.0$ & $1,712.0$ & 0 & 0 & 0 & 0 & 10.0 & 240.0 & 0 & 0 & 0 \\
\hline 1977 & 350.0 & $1,633.0$ & 606.0 & 0 & $1,188.0$ & 0 & 106.0 & 745.0 & 145.7 & 0 & 145.7 \\
\hline 1978 & 0 & 512.0 & 646.0 & 0 & $1,291.0$ & 0 & 67.0 & 745.0 & 92.7 & 0 & 92.7 \\
\hline 1979 & 0 & $1,897.0$ & $1,136.0$ & 0 & $1,435.0$ & 0 & 67.7 & 745.0 & 138.7 & 0 & 138.7 \\
\hline 1980 & 0 & $2,455.0$ & $1,768.0$ & 0 & $1,393.0$ & 0 & 55.3 & 0 & 147.7 & 0 & 147.7 \\
\hline 1981 & 0 & $3,072.0$ & $1,838.0$ & 0 & $1,468.0$ & 0 & 67.7 & 495.0 & 224.7 & 0 & 224.7 \\
\hline 1982 & 0 & 0 & 0 & 0 & $1,213.0$ & 0 & 67.7 & 0 & 423.7 & 0 & 423.7 \\
\hline 1983 & 0 & 0 & 0 & 0 & 748.0 & 0 & 0 & 0 & 0 & 0 & 0 \\
\hline 1984 & 0 & 0 & 806.0 & 0 & 381.0 & 0 & 67.4 & 0 & 0 & 0 & 0 \\
\hline 1985 & 0 & 0 & 746.0 & 4.0 & 339.0 & 0 & 67.7 & 0 & 0 & 0 & 0 \\
\hline 1986 & 0 & 0 & 584.0 & 8.0 & 10.0 & 0 & 67.7 & 0 & 0 & 0 & 0 \\
\hline 1987 & 0 & 0 & 634.0 & 11.0 & 12.0 & 0 & 84.9 & 0 & 19.0 & 0 & 19.0 \\
\hline 1988 & 0 & 0 & 641.0 & 8.0 & 12.0 & 0 & 84.9 & 0 & 0 & 156.0 & 156.0 \\
\hline 1989 & 0 & 0 & 637.0 & 12.0 & 11.0 & 0 & 84.9 & 0 & 0 & 213.0 & 213.0 \\
\hline 1990 & 0 & 0 & 0 & 12.0 & 11.0 & 0 & 84.9 & 0 & 0 & 61.0 & 61.0 \\
\hline 1991 & 0 & $-1,398.0$ & 0 & 6.0 & 0 & 0 & 84.9 & 0 & 0 & 1.0 & 1.0 \\
\hline 1992 & 0 & 0 & 0 & 7.0 & 2.0 & 0 & 0 & 0 & 0 & 0 & 0 \\
\hline
\end{tabular}


Table 19. Water-use information for self-supplied water users in Antelope Valley by water-supply sources, 1946-92-Continued

\begin{tabular}{|c|c|c|c|c|c|c|c|c|c|}
\hline \multirow{2}{*}{ Year } & $\begin{array}{l}\text { Kellerman, } \\
\text { Pat }\end{array}$ & $\begin{array}{l}\text { Kelly } \\
\text { Ranch }\end{array}$ & $\begin{array}{c}\text { Kindig, } \\
\text { George B. }\end{array}$ & $\begin{array}{l}\text { Kindig, } \\
\text { Paul S. }\end{array}$ & $\begin{array}{c}\text { Kieksted } \\
\text { Tree } \\
\text { Farm }\end{array}$ & $\begin{array}{l}\text { Kuete, } \\
\text { Les }\end{array}$ & $\begin{array}{c}\text { Kungl, } \\
\text { Karl }\end{array}$ & $\begin{array}{l}\text { Kyle, J.W. } \\
\text { and G.W. }\end{array}$ & $\begin{array}{l}\text { Lade, R.M.I } \\
\text { Hartford } \\
\text { Management } \\
\text { Company }\end{array}$ \\
\hline & Purchased & Purchased & $\begin{array}{c}\text { Ground } \\
\text { water }\end{array}$ & $\begin{array}{l}\text { Ground } \\
\text { water }\end{array}$ & Purchased & Purchased & $\begin{array}{c}\text { Ground } \\
\text { water }\end{array}$ & $\begin{array}{l}\text { Ground } \\
\text { water }\end{array}$ & $\begin{array}{c}\text { Ground } \\
\text { water }\end{array}$ \\
\hline 1946 & - & - & 0 & 0 & -- & $\overline{-}$ & 0 & 0 & 0 \\
\hline 1947 & - & -- & 0 & 0 & .- & -- & 577.0 & $3,857.0$ & 520.0 \\
\hline 1948 & -. & -- & 0 & 0 & -- & -- & 560.0 & $3,494.0$ & 520.0 \\
\hline 1949 & .. & -. & $1,230.0$ & 0 & -. & .. & 570.0 & $3,173.0$ & 702.0 \\
\hline 1950 & .. & -- & 0 & 0 & .. & .. & 540.0 & $3,857.0$ & 702.0 \\
\hline 1951 & -- & -- & 409.0 & 0 & -- & -- & 578.0 & $2,484.0$ & 702.0 \\
\hline 1952 & -- & -- & 0 & 0 & -- & -- & 740.0 & $2,878.0$ & 116.0 \\
\hline 1953 & - & -- & $1,269.0$ & 0 & -- & -- & 220.0 & $3,326.0$ & 561.0 \\
\hline 1954 & _- & .. & 473.0 & 0 & -. & -- & 563.0 & $3,290.0$ & 702.0 \\
\hline 1955 & -- & -- & 638.0 & 0 & -- & -- & 578.0 & $4,656.0$ & 702.0 \\
\hline 1956 & -- & -- & 347.0 & 435.0 & -. & -- & 672.0 & $3,023.0$ & 654.0 \\
\hline 1957 & -- & -- & 425.0 & 402.0 & -- & -- & 336.0 & 817.0 & 839.0 \\
\hline 1958 & .- & -- & 44.0 & 479.0 & -- & -- & 229.0 & $2,534.0$ & 714.0 \\
\hline 1959 & -- & -. & 0 & 480.0 & -- & -. & 605.0 & $4,793.0$ & 694.0 \\
\hline 1960 & -- & .- & 600.0 & 518.0 & .- & .- & 582.0 & $3,993.0$ & 820.0 \\
\hline 1961 & -- & -. & $1,008.0$ & 512.0 & -- & -- & 260.0 & $3,685.0$ & 756.0 \\
\hline 1962 & -- & -- & 93.0 & 511.0 & -- & .- & 140.0 & $3,431.0$ & 793.0 \\
\hline 1963 & -- & -- & 36.0 & 502.0 & -. & -- & 254.0 & $3,185.0$ & 710.0 \\
\hline 1964 & -- & -- & 756.0 & 486.0 & -. & -. & 636.0 & $4,591.0$ & 671.0 \\
\hline 1965 & -. & -- & 478.0 & 492.0 & -- & -- & 550.0 & $4,164.0$ & 695.0 \\
\hline 1966 & -- & -. & 490.0 & 406.0 & .- & .. & 630.0 & $4,200.0$ & 684.0 \\
\hline 1967 & -- & -- & 510.0 & 540.0 & -- & -- & 84.0 & $3,120.0$ & $1,178.0$ \\
\hline 1968 & -- & .- & 550.0 & 528.0 & .- & --. & 585.0 & $5,012.0$ & 0 \\
\hline 1969 & -- & -- & 550.0 & 492.0 & -- & -- & 580.0 & $4,460.0$ & 560.0 \\
\hline 1970 & -. & -- & 500.0 & 506.0 & -- & .. & 570.0 & $2,254.0$ & 898.0 \\
\hline 1971 & - & .. & 550.0 & 478.0 & -- & -. & 490.0 & $5,111.0$ & 895.0 \\
\hline 1972 & -- & -. & 0 & 0 & -- & .. & 0 & $1,593.0$ & 0 \\
\hline 1973 & .- & $\therefore$ & 520.0 & 615.0 & .. & .. & 400.0 & $4,862.0$ & 560.0 \\
\hline 1974 & -. & -- & 540.0 & 496.0 & .. & .. & 400.0 & $4,028.0$ & 560.0 \\
\hline 1975 & -. & -- & 560.0 & 514.0 & .. & .. & 400.0 & $3,959.0$ & 600.0 \\
\hline 1976 & 0 & 0 & 500.0 & 478.0 & 0 & 0 & 400.0 & $3,696.0$ & 0 \\
\hline 1977 & 0 & $1,707.0$ & $1,020.0$ & 416.0 & 0 & 0 & 420.0 & $4,689.0$ & 0 \\
\hline 1978 & 0 & $3,795.0$ & $1,050.0$ & 437.0 & 0 & 0 & 300.0 & $4,938.0$ & 0 \\
\hline 1979 & 0 & $4,654.0$ & 0 & 416.0 & 0 & 0 & 0 & $5,550.0$ & 0 \\
\hline 1980 & 0 & $4,819.0$ & 730.0 & 440.0 & 0 & 1.0 & 270.0 & $5,697.4$ & 0 \\
\hline 1981 & 0 & $4,929.0$ & 680.0 & 390.0 & 0 & 4.0 & 270.0 & $5,058.2$ & 0 \\
\hline 1982 & 0 & $4,613.0$ & 0 & 392.0 & 0 & $9.0^{\circ}$ & 200.0 & $6,024.8$ & 0 \\
\hline 1983 & 0 & $2,972.0$ & 385.0 & 392.0 & 0 & 6.0 & 50.0 & $7,108.8$ & 0 \\
\hline 1984 & 0 & $2,440.0$ & 600.0 & 395.0 & 0 & 6.0 & 0 & $6,023.2$ & 0 \\
\hline 1985 & 0 & $2,377.0$ & 620.0 & 385.0 & 23.0 & 6.0 & 25.0 & $6,939.6$ & 0 \\
\hline 1986 & 0 & $1,267.0$ & 600.0 & 390.0 & 56.0 & 6.0 & 20.0 & $6,939.6$ & 0 \\
\hline 1987 & 0 & $1,992.0$ & 620.0 & 390.0 & 75.0 & 6.0 & 15.0 & $7,128.6$ & 0 \\
\hline 1988 & 0 & $1,900.0$ & 0 & 0 & 90.0 & 6.0 & 0 & 795.6 & 0 \\
\hline 1989 & 0 & $2,166.0$ & 590.0 & 150.0 & 122.0 & 6.0 & 15.0 & $7,179.0$ & 0 \\
\hline 1990 & 5.0 & $1,708.0$ & 20.0 & 10.0 & 0 & 6.0 & 15.0 & $6,927.8$ & 0 \\
\hline 1991 & 6.0 & 0 & 0 & 0 & 0 & 6.0 & 15.0 & $7,294.0$ & 0 \\
\hline 1992 & 6.0 & 0 & 0 & 0 & 0 & 6.0 & 0 & 0 & 0 \\
\hline
\end{tabular}


Table 19. Water-use information for self-supplied water users in Antelope Vailey by water-supply sources, 1946-92--Continued

\begin{tabular}{|c|c|c|c|c|c|c|c|c|c|c|c|}
\hline \multirow{2}{*}{ Year } & \multirow{2}{*}{$\begin{array}{c}\text { Lake, Twyla } \\
\text { and Larry } \\
\begin{array}{c}\text { Ground } \\
\text { water }\end{array}\end{array}$} & \multicolumn{3}{|c|}{ Lane, Frank A. } & \multicolumn{3}{|c|}{ Larsen Brothers } & \multirow{2}{*}{$\begin{array}{c}\text { Leona Valley } \\
\text { Estates } \\
\text { Limited } \\
\text { Management } \\
\text { Purchased }\end{array}$} & \multirow{2}{*}{ 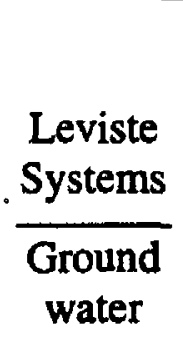 } & \multirow{2}{*}{$\begin{array}{c}\text { Littlerock } \\
\text { Aggregate } \\
\text { Company }\end{array}$} & \multirow{2}{*}{$\begin{array}{c}\begin{array}{c}\text { Llarena, } \\
\text { Albert }\end{array} \\
\begin{array}{c}\text { Ground } \\
\text { water }\end{array}\end{array}$} \\
\hline & & $\begin{array}{l}\text { Ground } \\
\text { water }\end{array}$ & $\begin{array}{c}\text { Pur- } \\
\text { chased }\end{array}$ & Total & $\begin{array}{l}\text { Ground } \\
\text { water }\end{array}$ & $\begin{array}{c}\text { Pur- } \\
\text { chased }\end{array}$ & Total & & & & \\
\hline 1946 & 0 & 0 & -- & 0 & 0 & -- & 0 & -- & 0 & 0 & 0 \\
\hline 1947 & 0 & 0 & -- & 0 & 18.0 & -- & 18.0 & -- & 0 & 0 & $1,786.0$ \\
\hline 1948 & $1,329.0$ & 0 & -- & 0 & 22.0 & -- & 22.0 & -- & 266.0 & 0 & $1,303.0$ \\
\hline 1949 & 539.0 & 0 & -. & 0 & 21.0 & -- & 21.0 & -- & 75.0 & 0 & $1,447.0$ \\
\hline 1950 & 882.0 & 0 & -- & 0 & 276.0 & -- & 276.0 & -- & 546.0 & 0 & $1,786.0$ \\
\hline 1951 & $1,628.0$ & 0 & -- & 0 & 261.0 & -- & 261.0 & -- & 36.0 & 0 & $1,952.0$ \\
\hline 1952 & $1,512.0$ & 0 & -- & 0 & 254.0 & -_ & 254.0 & -- & 26.0 & 0 & $1,786.0$ \\
\hline 1953 & $1,769.0$ & 0 & -- & 0 & 250.0 & -- & 250.0 & -- & 161.0 & 0 & $1,786.0$ \\
\hline 1954 & $1,545.0$ & 0 & -- & 0 & 322.0 & -- & 322.0 & -- & $1,252.0$ & 30.0 & $1,164.0$ \\
\hline 1955 & $2,856.0$ & 0 & -- & 0 & 244.0 & -- & 244.0 & -- & 0 & 0 & $1,786.0$ \\
\hline 1956 & $1,580.0$ & 0 & -- & 0 & 231.0 & -- & 231.0 & -- & 100.0 & 205.0 & $1,862.0$ \\
\hline 1957 & $2,418.0$ & 0 & -- & 0 & 92.0 & -- & 92.0 & -- & 18.0 & 191.0 & $1,910.0$ \\
\hline 1958 & $2,530.0$ & 0 & -- & 0 & 455.0 & -- & 455.0 & -- & 100.0 & 148.0 & $2,012.0$ \\
\hline 1959 & 496.0 & 0 & -- & 0 & 126.0 & -- & 126.0 & -- & 10.0 & 30.0 & 985.0 \\
\hline 1960 & $2,912.0$ & 0 & -- & 0 & 95.0 & -- & 95.0 & -- & $1,008.0$ & 124.0 & $2,010.0$ \\
\hline 1961 & $2,837.0$ & 0 & -- & 0 & 108.0 & -- & 108.0 & -- & 0 & 22.0 & $2,017.0$ \\
\hline 1962 & $1,301.0$ & 0 & -- & 0 & 102.0 & -- & 102.0 & -- & $1,008.0$ & 128.0 & 439.0 \\
\hline 1963 & $2,060.0$ & 0 & -- & 0 & 90.0 & -- & 90.0 & -- & $1,008.0$ & 172.0 & 920.0 \\
\hline 1964 & $1,920.0$ & 0 & -- & 0 & 697.0 & -- & 697.0 & -- & $1,008.0$ & 172.0 & $1,015.0$ \\
\hline 1965 & $2,584.0$ & 0 & -- & 0 & 691.0 & -- & 691.0 & -- & 0 & 172.0 & 0 \\
\hline 1966 & $1,328.0$ & 0 & -- & 0 & 570.0 & -- & 570.0 & -. & 0 & 172.0 & 500.0 \\
\hline 1967 & $2,342.0$ & 0 & -- & 0 & 317.0 & -- & 317.0 & -- & 0 & 172.0 & 927.0 \\
\hline 1968 & $1,124.0$ & 0 & -- & 0 & 148.0 & -- & 148.0 & -- & 9.0 & 172.0 & 0 \\
\hline 1969 & 260.0 & 0 & -- & 0 & 170.0 & -- & 170.0 & -- & 600.0 & $1,034.0$ & 762.0 \\
\hline 1970 & $2,674.0$ & 411.0 & -- & 411.0 & 272.0 & -- & 272.0 & -- & 600.0 & $1,034,0$ & $1,120.0$ \\
\hline 1971 & $2,671.0$ & 411.0 & -- & 411.0 & 291.0 & -- & 291.0 & -- & 0 & $1,034.0$ & 0 \\
\hline 1972 & $1,341.0$ & 22.0 & -. & 22.0 & 0 & -- & 0 & -- & 600.0 & 0 & 0 \\
\hline 1973 & 0 & 380.0 & -- & 380.0 & 775.0 & -- & 775.0 & -- & 600.0 & $1,034.0$ & 0 \\
\hline 1974 & 0 & 365.0 & -- & 365.0 & 500.0 & -- & 500.0 & .- & 350.0 & $1,034.0$ & 0 \\
\hline 1975 & 0 & 365.0 & -- & 365.0 & 83.0 & -- & 83.0 & -- & 350.0 & $1,034.0$ & 0 \\
\hline 1976 & $1,960.0$ & 250.0 & 0 & 250.0 & 432.0 & 0 & 432.0 & 0 & 350.0 & $1,034.0$ & 0 \\
\hline 1977 & $1,962.0$ & 250.0 & 0 & 250.0 & 828.0 & $2,580.0$ & $3,408.0$ & 0 & 350.0 & $1,034.0$ & 0 \\
\hline 1978 & $1,962.0$ & 0 & 0 & 0 & 847.0 & $1,151.0$ & $1,998.0$ & 0 & 350.0 & $1,034.0$ & 0 \\
\hline 1979 & $1,818.0$ & 0 & 0 & 0 & 833.0 & $1,579.0$ & $2,412.0$ & 2.0 & 350.0 & $1,034.0$ & 0 \\
\hline 1980 & $2,058.0$ & 0 & 17.0 & 17.0 & 835.0 & $2,066.0$ & $2,901.0$ & 2.0 & 350.0 & $1,034.0$ & 0 \\
\hline 1981 & $2,058.0$ & 0 & 28.0 & 28.0 & 854.0 & $2,965.0$ & $3,819.0$ & 16.0 & 350.0 & $1,034.0$ & 0 \\
\hline 1982 & $2,058.0$ & 0 & 29.0 & 29.0 & 620.0 & $1,996.0$ & $2,616.0$ & 7.0 & 350.0 & 131.4 & 0 \\
\hline 1983 & $2,058.0$ & 0 & 37.0 & 37.0 & 657.0 & $1,029.0$ & $1,686.0$ & 6.0 & 350.0 & 132.0 & 0 \\
\hline 1984 & $2,058.0$ & 0 & 41.0 & 41.0 & 545.0 & 136.0 & 681.0 & 7.0 & 350.0 & 132.0 & 0 \\
\hline 1985 & $2,058.0$ & 0 & 42.0 & 42.0 & 594.0 & $2,114.0$ & $2,708.0$ & 4.0 & 350.0 & 132.0 & 0 \\
\hline 1986 & $2,058.0$ & 0 & 48.0 & 48.0 & 355.0 & 785.0 & $1,140.0$ & 3.0 & 0 & 132.0 & 0 \\
\hline 1987 & $2,058.0$ & 0 & 53.0 & 53.0 & 75.0 & 0 & 75.0 & 6.0 & 0 & 0 & 0 \\
\hline 1988 & 0 & 960.0 & 76.0 & $1,036.0$ & 0 & 0 & 0 & 9.0 & 0 & 0 & 0 \\
\hline 1989 & $2,058.0$ & 0 & 74.0 & 74.0 & 0 & 0 & 0 & 35.0 & 0 & 132.0 & 0 \\
\hline 1990 & $2,052.0$ & 960.0 & 73.0 & $1,033.0$ & 0 & 0 & 0 & 10.0 & 0 & 132.0 & 0 \\
\hline 1991 & 12.0 & 0 & 34.0 & 34.0 & 0 & 0 & 0 & 6.0 & 0 & 307.0 & 0 \\
\hline 1992 & 0 & 0 & 31.0 & 31.0 & 0 & 0 & 0 & 4.0 & 0 & 0 & 0 \\
\hline
\end{tabular}


Table 19. Water-use information for self-supplied water users in Antelope Valley by water-supply sources, 1946-92--Continued

\begin{tabular}{|c|c|c|c|c|c|c|}
\hline \multirow{2}{*}{ Year } & $\begin{array}{l}\text { Los Angeles } \\
\text { Department } \\
\text { of Airports }\end{array}$ & $\begin{array}{l}\text { Los Angeles } \\
\text { Firemen's Relief } \\
\text { Association }\end{array}$ & $\begin{array}{l}\text { Margaretten, } \\
\text { Joel }\end{array}$ & $\begin{array}{l}\text { Mc Cormick, } \\
\text { Raymond W. }\end{array}$ & $\begin{array}{l}\text { Mescal Creek } \\
\text { Water Trust }\end{array}$ & $\begin{array}{l}\text { Miccolis, F.P./ } \\
\text { Adele Bruno }\end{array}$ \\
\hline & $\begin{array}{l}\text { Ground } \\
\text { water }\end{array}$ & $\begin{array}{c}\text { Ground } \\
\text { water }\end{array}$ & $\begin{array}{c}\text { Surface } \\
\text { water }\end{array}$ & $\begin{array}{l}\text { Ground } \\
\text { water }\end{array}$ & $\begin{array}{c}\text { Surface } \\
\text { water }\end{array}$ & $\begin{array}{c}\text { Ground } \\
\text { water }\end{array}$ \\
\hline 1946 & 0 & 0 & 3.4 & 0 & -- & 0 \\
\hline 1947 & 0 & 366.0 & 3.4 & 0 & -- & 600.0 \\
\hline 1948 & 0 & $1,745.0$ & 3.4 & 705.0 & -- & 600.0 \\
\hline 1949 & 251.0 & 731.0 & -- & 705.0 & -- & 190.0 \\
\hline 1950 & 0 & 616.0 & -- & 705.0 & -- & . 600.0 \\
\hline 1951 & 0 & $1,825.0$ & - & 705.0 & -- & 600.0 \\
\hline 1952 & 0 & 790.0 & 1.1 & 705.0 & -- & 595.0 \\
\hline 1953 & 764.0 & $1,357.0$ & 1.1 & 705.0 & -- & $1,312.0$ \\
\hline 1954 & 157.0 & $1,580.0$ & 1.1 & 705.0 & -- & 57.0 \\
\hline 1955 & 0 & 766.0 & -- & 705.0 & -- & 600.0 \\
\hline 1956 & 42.0 & $2,398.0$ & -- & 705.0 & -- & $1,105.0$ \\
\hline 1957 & 73.0 & 618.0 & 9.7 & 480.0 & -- & 183.0 \\
\hline 1958 & $1,859.0$ & $1,712.0$ & -- & 480.0 & .- & 140.0 \\
\hline 1959 & 102.0 & $2,020.0$ & -- & 480.0 & -- & 960.0 \\
\hline 1960 & 123.0 & 850.0 & 1.6 & 480.0 & -- & 80.0 \\
\hline 1961 & 1.0 & 1055.0 & 1.6 & 0 & -- & 198.0 \\
\hline 1962 & 48.0 & 238.0 & 1.6 & 480.0 & - & 31.0 \\
\hline 1963 & 553.0 & $1,070.0$ & 1.6 & 400.0 & 868.8 & 150.0 \\
\hline 1964 & 875.0 & 335.0 & 1.6 & 0 & 868.8 & 645.0 \\
\hline 1965 & 446.0 & 0 & 1.6 & 400.0 & 868.8 & 150.0 \\
\hline 1966 & 933.0 & $1,093.0$ & 19.7 & 400.0 & 868.8 & 100.0 \\
\hline 1967 & $3,595.0$ & 5.0 & 19.7 & 400.0 & 868.8 & 0 \\
\hline 1968 & $4,574.0$ & $1,300.0$ & 19.7 & 400.0 & 868.8 & $1,078.0$ \\
\hline 1969 & $4,528.0$ & $1,385.0$ & 19.7 & 400.0 & 868.8 & 0 \\
\hline 1970 & $3,784.0$ & 200.0 & 19.7 & 963.0 & 868.8 & 0 \\
\hline 1971 & $4,354.0$ & 0 & 19.7 & 240.0 & 868.8 & 0 \\
\hline 1972 & $2,792.0$ & 0 & 19.7 & 769.0 & 868.8 & 0 \\
\hline 1973 & $4,447.0$ & $1,692.0$ & 19.7 & 963.0 & 868.8 & 0 \\
\hline 1974 & $4,637.0$ & $1,692.0$ & 19.7 & 963.0 & 868.8 & 0 \\
\hline 1975 & $3,915.0$ & $1,692.0$ & 19.7 & 963.0 & 868.8 & 0 \\
\hline 1976 & $3,957.0$ & $1,982.0$ & 19.7 & 963.0 & 868.8 & 0 \\
\hline 1977 & $4,002.0$ & $1,982.0$ & 19.7 & $1,280.0$ & 868.8 & 0 \\
\hline 1978 & 181.0 & $2,100.0$ & 18.1 & $1,280.0$ & 868.8 & 0 \\
\hline 1979 & 181.0 & $5,882.2$ & 19.7 & $1,280.0$ & 868.8 & 0 \\
\hline 1980 & 173.5 & 0 & 19.7 & 0 & 868.8 & 0 \\
\hline 1981 & 0 & 325.0 & 19.7 & 240.0 & 868.8 & 0 \\
\hline 1982 & 4.6 & 0 & 19.7 & 0 & 868.8 & 0 \\
\hline 1983 & 25.0 & 325.0 & 19.7 & 0 & 868.8 & 0 \\
\hline 1984 & 56.0 & 325.0 & 19.7 & 0 & 868.8 & 0 \\
\hline 1985 & 343.4 & 0 & 19.7 & 0 & 868.8 & 0 \\
\hline 1986 & 355.4 & $2,405.7$ & 19.7 & 0 & 868.8 & 0 \\
\hline 1987 & 370.8 & $2,413.1$ & 19.7 & 0 & 868.8 & 0 \\
\hline 1988 & 362.4 & 0 & 19.7 & 0 & 868.8 & 0 \\
\hline 1989 & 0 & 969.5 & 19.7 & 0 & 868.8 & 0 \\
\hline 1990 & 370.4 & 0 & 19.7 & 0 & 868.8 & 0 \\
\hline 1991 & $2,876.8$ & 700.1 & 18.1 & 0 & 868.8 & 0 \\
\hline 1992 & 0 & 0 & 18.1 & 0 & 868.8 & 0 \\
\hline
\end{tabular}


Table 19. Water-use information for self-supplied water users in Antelope Valley by water-supply sources, 1946-92--Continued

\begin{tabular}{|c|c|c|c|c|c|c|c|c|}
\hline \multirow{2}{*}{ Year } & \multirow{2}{*}{$\begin{array}{c}\begin{array}{c}\text { Milford, } \\
\text { Terry }\end{array} \\
\text { Purchased }\end{array}$} & \multirow{2}{*}{$\begin{array}{c}\begin{array}{c}\text { Miller, } \\
\text { Kieth }\end{array} \\
\text { Purchased }\end{array}$} & \multirow{2}{*}{$\begin{array}{c}\begin{array}{c}\text { Mitchel } \\
\text { and } \\
\text { Gunning }\end{array} \\
\text { Purchased }\end{array}$} & \multirow{2}{*}{$\frac{\begin{array}{c}\text { Monsello, } \\
\text { Andrew }\end{array}}{\begin{array}{c}\text { Ground } \\
\text { water }\end{array}}$} & \multirow{2}{*}{$\begin{array}{c}\text { Morgan, } \\
\text { Carlos M., } \\
\text { Estate of } \\
\begin{array}{c}\text { Ground } \\
\text { water }\end{array}\end{array}$} & \multirow{2}{*}{$\begin{array}{c}\text { Morris, } \\
\text { Wayne F. and } \\
\text { Annette L. } \\
\begin{array}{c}\text { Surface } \\
\text { water }\end{array}\end{array}$} & \multirow{2}{*}{$\begin{array}{c}\begin{array}{c}\text { Mountain } \\
\text { Glen } \\
\text { Ranch }\end{array} \\
\begin{array}{c}\text { Ground } \\
\text { water }\end{array}\end{array}$} & \multirow{2}{*}{$\begin{array}{c}\begin{array}{c}\text { Mountain } \\
\text { High-Holiday }\end{array} \\
\text { Hill Company } \\
\begin{array}{c}\text { Ground } \\
\text { water }\end{array}\end{array}$} \\
\hline & & & & & & & & \\
\hline$\overline{1946}$ & -- & -- & -- & 0 & 0 & 1.6 & 0 & 0 \\
\hline 1947 & -- & -- & -- & 0 & 0 & 1.6 & 0 & 0 \\
\hline 1948 & -- & .- & .. & 0 & 0 & 1.6 & 0 & 0 \\
\hline 1949 & -- & .- &.-- & 0 & 100.0 & 1.6 & 0 & 0 \\
\hline 1950 & -- & -- & -- & 0 & 0 & 1.6 & 0 & 0 \\
\hline 1951 & -- & -- & .- & 0 & 19.0 & 1.6 & 0 & 0 \\
\hline 1952 & -- & -- & -- & 290.0 & 44.0 & 1.6 & 0 & 0 \\
\hline 1953 & -- & .- & .. & 290.0 & $1,825.0$ & 1.6 & 0 & 0 \\
\hline 1954 & -- & -- & .- & 290.0 & 311.0 & 1.6 & 0 & 0 \\
\hline 1955 & -- & -- & -- & 280.0 & 41.0 & 1.6 & 0 & 0 \\
\hline 1956 & .- & -- & -- & 280.0 & 12.0 & 1.6 & 30.0 & 0 \\
\hline 1957 & -- & -- & .- & 70.0 & 4.0 & 1.6 & 0 & 0 \\
\hline 1958 & .- & .- & .. & 164.0 & 75.0 & 1.6 & 0 & 0 \\
\hline 1959 & .- & .. & .- & 0 & 650.0 & 1.6 & 29.0 & 0 \\
\hline 1960 & -- & -- & -- & 0 & 14.0 & 1.6 & 223.0 & 0 \\
\hline 1961 & -. & .. & -. & 0 & 176.0 & 1.6 & 448.0 & 0 \\
\hline 1962 & -- & .- & -. & 0 & 50.0 & 1.6 & 376.0 & 0 \\
\hline 1963 & -- & .. & .- & 0 & 27.0 & 1.6 & 185.0 & 0 \\
\hline 1964 & -- & -- & -- & 0 & 286.0 & 1.6 & 208.0 & 0 \\
\hline 1965 & .. & -- & -- & 0 & 55.0 & 1.6 & 0 . & 0 \\
\hline 1966 & .- & .. & $\therefore$ & 0 & 46.0 & 1.6 & $3,453.0$ & 0 \\
\hline 1967 & -- & -- & -- & 0 & 66.0 & 1.6 & $1,000.0$ & 0 \\
\hline 1968 & -- & -- & -- & 190.0 & 70.0 & 1.6 & 65.0 & 0 \\
\hline 1969 & -- & -- & -- & 290.0 & 388.0 & 1.6 & $1,154.0$ & 0 \\
\hline 1970 & -- & -- & -- & 0 & 0 & 1.6 & 50.0 & 0 \\
\hline 1971 & -- & -- & -- & 190.0 & 150.0 & 1.6 & 50.0 & 0 \\
\hline 1972 & -- & -- & -- & 0 & 0 & 1.6 & 472.0 & 13.0 \\
\hline 1973 & -- & -- & -- & 198.0 & 165.0 & 1.6 & 50.0 & 569.0 \\
\hline 1974 & -- & -- & -- & 190.0 & 165.0 & 1.6 & 0 & 560.0 \\
\hline 1975 & -- & -- & -- & 160.0 & 165.0 & 1.6 & 0 & 560.0 \\
\hline 1976 & 0 & 0 & 0 & 100.0 & 165.0 & 1.6 & 0 & 560.0 \\
\hline 1977 & 0 & 0 & 0 & 100.0 & 18.0 & 1.6 & 64.0 & 51.0 \\
\hline 1978 & 0 & 0 & $1,304.0$ & 0 & 18.0 & 1.6 & 0 & 55.0 \\
\hline 1979 & 0 & 3.0 & $1,698.0$ & 0 & 0 & 1.6 & 0 & 0 \\
\hline 1980 & 0 & 2.0 & $1,933.0$ & 0 & 165.0 & 1.6 & 0 & 41.0 \\
\hline 1981 & 0 & 3.0 & $1,481.0$ & 0 & 165.0 & 1.6 & 0 & 25.0 \\
\hline 1982 & 3.0 & 4.0 & $1,316.0$ & 0 & 25.0 & 1.6 & 0 & 180.0 \\
\hline 1983 & 6.0 & 9.0 & $1,281.0$ & 0 & 25.0 & 1.6 & 0 & 0 \\
\hline 1984 & 6.0 & 11.0 & 0 & 0 & 27.0 & 1.6 & 0 & 27.0 \\
\hline 1985 & 7.0 & 11.0 & 0 & 0 & 25.0 & 1.6 & 0 & 24.0 \\
\hline 1986 & 7.0 & 10.0 & 0 & 0 & 12.0 & 1.6 & 0 & 49.0 \\
\hline 1987 & 6.0 & 14.0 & 0 & 0 & 20.0 & 1.6 & 0 & 9.0 \\
\hline 1988 & 6.0 & 13.0 & 0 & 0 & 12.0 & 1.6 & 0 & 0 \\
\hline 1989 & 6.0 & 14.0 & 0 & 0 & 9.9 & 1.6 & 0 & 180.0 \\
\hline 1990 & 7.0 & 14.0 & 0 & 0 & 0 & 1.6 & 0 & 30.0 \\
\hline 1991 & 6.0 & 10.0 & 0 & 0 & 0 & 1.6 & 0 & 14.0 \\
\hline 1992 & 6.0 & 11.0 & 46.0 & 0 & 0 & 1.6 & 0 & 0 \\
\hline
\end{tabular}


Table 19. Water-use information for self-supplied water users in Antelope Valley by water-supply sources, 1946-92--Continued

\begin{tabular}{|c|c|c|c|c|c|c|c|}
\hline Year & $\begin{array}{c}\begin{array}{c}\text { Nakasone } \\
\text { Development } \\
\text { Company }\end{array} \\
\begin{array}{c}\text { Ground } \\
\text { water }\end{array}\end{array}$ & $\begin{array}{c}\text { Nebeker, E.A., } \\
\text { and others, } \\
\text { Estate of } \\
\begin{array}{c}\text { Ground } \\
\text { water }\end{array}\end{array}$ & $\begin{array}{c}\begin{array}{c}\text { Nishimoto, } \\
\text { Jimmie } M .\end{array} \\
\begin{array}{c}\text { Ground } \\
\text { water }\end{array}\end{array}$ & $\begin{array}{c}\begin{array}{c}\text { Nishimoto, } \\
\text { Roy }\end{array} \\
\begin{array}{c}\text { Ground } \\
\text { water }\end{array}\end{array}$ & $\begin{array}{c}\begin{array}{c}\text { Ordway, } \\
\text { Ben F. }\end{array} \\
\begin{array}{c}\text { Surface } \\
\text { water }\end{array}\end{array}$ & $\begin{array}{c}\begin{array}{c}\text { Pablo, Mr. } \\
\text { and } \\
\text { Mrs. Pastor }\end{array} \\
\begin{array}{c}\text { Ground } \\
\text { water }\end{array}\end{array}$ & $\begin{array}{l}\text { Peachland } \\
\text { Farms } \\
\text { Purchased }\end{array}$ \\
\hline$\overline{1946}$ & 0 & 0 & 0 & 0 & 29.0 & 0 & -- \\
\hline 1947 & $1,344.0$ & $2,906.0$ & 410.0 & 0 & 29.0 & 0 & -- \\
\hline 1948 & $1,120.0$ & $1,805.0$ & 54.0 & 0 & 29.0 & 748.0 & -- \\
\hline 1949 & $1,120.0$ & $1,374.0$ & 9.0 & 0 & 29.0 & 748.0 & -- \\
\hline 1950 & $1,120.0$ & $3,042.0$ & 410.0 & 0 & 29.0 & 748.0 & -- \\
\hline 1951 & 600.0 & $3,775.0$ & 629.0 & 0 & 29.0 & 805.0 & -- \\
\hline 1952 & $1,649.0$ & $2,984.0$ & 370.0 & 0 & 29.0 & 748.0 & -- \\
\hline 1953 & 600.0 & $1,079.0$ & $1,006.0$ & 0 & 29.0 & 625.0 & -- \\
\hline 1954 & $1,350.0$ & $2,540.0$ & $1,214.0$ & 0 & 29.0 & 697.0 & -- \\
\hline 1955 & $1,800.0$ & $3,905.0$ & 377.0 & 0 & 29.0 & 695.0 & -- \\
\hline 1956 & $1,800.0$ & $3,520.0$ & 190.0 & 528.0 & 29.0 & $2,135.0$ & - \\
\hline 1957 & 990.0 & $3,870.0$ & 318.0 & 0 & 29.0 & $2,135.0$ & -- \\
\hline 1958 & $2,433.0$ & $1,851.0$ & 129.0 & 0 & 29.0 & $2,130.0$ & -- \\
\hline 1959 & $1,363.0$ & $1,768.0$ & 13.0 & 0 & 29.0 & $2,587.0$ & -- \\
\hline 1960 & $1,800.0$ & $3,433.0$ & 260.0 & 0 & 29.0 & $2,040.0$ & $\ldots$ \\
\hline 1961 & $2,000.0$ & $4,145.0$ & 250.0 & 36.0 & 29.0 & $1,560.0$ & -- \\
\hline 1962 & $2,471.0$ & $2,224.0$ & 920.0 & 0 & 29.0 & $1,620.0$ & -- \\
\hline 1963 & $2,492.0$ & $2,544.0$ & 71.0 & 0 & 29.0 & $2,961.0$ & -- \\
\hline 1964 & $1,691.0$ & $3,112.0$ & 24.0 & 7.0 & 29.0 & $2,244.0$ & -- \\
\hline 1965 & $2,000.0$ & $3,225.0$ & 330.0 & 0 & 29.0 & 0 & -- \\
\hline 1966 & $3,600.0$ & $4,010.0$ & 684.0 & 520.0 & 29.0 & $1,072.0$ & $\cdots$ \\
\hline 1967 & $2,601.0$ & $2,665.0$ & 20.0 & 479.0 & 29.0 & 50.0 & $\cdots$ \\
\hline 1968 & $3,885.0$ & $4,431.0$ & 286.0 & 900.0 & 29.0 & 657.0 & -- \\
\hline 1969 & $2,663.0$ & $4,464.0$ & 284.0 & 930.0 & 29.0 & 862.0 & -- \\
\hline 1970 & $3,850.0$ & $4,089.0$ & 330.0 & 960.0 & 29.0 & 0 & -- \\
\hline 1971 & $3,850.0$ & $2,705.0$ & 330.0 & 6.0 & 29.0 & 0 & -- \\
\hline 1972 & 175.0 & 129.0 & 0 & 0 & 29.0 & 0 & -. \\
\hline 1973 & $3,850.0$ & $2,514.0$ & 315.0 & 6.0 & 29.0 & 0 & -- \\
\hline 1974 & $3,850.0$ & $2,161.0$ & 315.0 & 6.0 & 29.0 & 0 & -- \\
\hline 1975 & $3,850.0$ & $2,307.0$ & 315.0 & 6.0 & 29.0 & 0 & -- \\
\hline 1976 & $3,850.0$ & $2,498.0$ & 315.0 & 960.0 & 29.0 & 0 & 0 \\
\hline 1977 & $3,850.0$ & $2,364.0$ & 315.0 & 6.0 & 29.0 & 0 & 0 \\
\hline 1978 & $3,850.0$ & $2,364.0$ & 315.0 & 6.0 & 29.0 & 0 & 0 \\
\hline 1979 & $3,850.0$ & $2,364.0$ & 500.0 & 0 & 29.0 & 0 & 0 \\
\hline 1980 & $1,800.0$ & $1,973.0$ & 342.0 & 0 & 29.0 & 0 & 0 \\
\hline 1981 & $1,350.0$ & $2,216.0$ & 340.0 & 0 & 29.0 & 0 & 0 \\
\hline 1982 & 0 & $2,216.0$ & 340.0 & 0 & 29.0 & 0 & 0 \\
\hline 1983 & 0 & $2,216.0$ & 320.0 & 0 & 29.0 & 0 & 0 \\
\hline 1984 & 0 & $2,083.0$ & 0 & 0 & $29.0^{\circ}$ & 0 & 0 \\
\hline 1985 & 0 & $2,218.0$ & 0 & 0 & 29.0 & 0 & 0 \\
\hline 1986 & 0 & $2,218.0$ & 0 & 0 & 29.0 & 0 & 0 \\
\hline 1987 & 0 & $2,218.0$ & 0 & 0 & 29.0 & 0 & 0 \\
\hline 1988 & 0 & 0 & 0 & 0 & 29.0 & 0 & 66.0 \\
\hline 1989 & 0 & 219.0 & 0 & 0 & -- & 0 & 179.0 \\
\hline 1990 & 0 & 91.0 & 0 & 0 & -- & 0 & 274.0 \\
\hline 1991 & 0 & 190.0 & 0 & 0 & -. & 0 & 280.0 \\
\hline 1992 & 0 & 0 & 0 & 0 & -- & 0 & 288.0 \\
\hline
\end{tabular}


Table 19. Water-use information for self-supplled water users in Antelope Valley by water-supply sources, 1946-92-Continued

\begin{tabular}{|c|c|c|c|c|c|c|c|c|}
\hline \multirow{2}{*}{ Year } & \multirow{2}{*}{$\frac{\begin{array}{c}\text { Piani, } \\
\text { Gino }\end{array}}{\begin{array}{c}\text { Ground } \\
\text { water }\end{array}}$} & \multirow{2}{*}{$\begin{array}{c}\begin{array}{c}\text { Poncedelon, } \\
\text { Modesto }\end{array} \\
\text { Purchased }\end{array}$} & \multirow{2}{*}{$\frac{\text { Portanova }}{\text { Purchased }}$} & \multirow{2}{*}{$\begin{array}{l}\text { Pratt, } \\
\text { Doctor } \\
\text { W.H. }\end{array}$} & \multirow{2}{*}{$\begin{array}{c}\begin{array}{c}\text { Proctor, } \\
\text { Carl }\end{array} \\
\begin{array}{c}\text { Ground } \\
\text { water }\end{array}\end{array}$} & \multirow{2}{*}{$\begin{array}{c}\begin{array}{c}\text { Pulsipher } \\
\text { Enterprises }\end{array} \\
\text { Purchased }\end{array}$} & \multirow{2}{*}{$\begin{array}{c}\begin{array}{c}\text { Punchbowl } \\
\text { Canyon Water } \\
\text { Association }\end{array} \\
\begin{array}{c}\text { Surface } \\
\text { water }\end{array}\end{array}$} & \multirow{2}{*}{$\begin{array}{c}\mathrm{R} \text { and } \mathrm{M} \\
\text { Ranch } \\
\text { Incorporated } \\
\begin{array}{c}\text { Ground } \\
\text { water }\end{array}\end{array}$} \\
\hline & & & & & & & & \\
\hline 1946 & 0 & -- & -- & 0 & 0 & -- & -- & 0 \\
\hline 1947 & 0 & -. & -- & 0 & 640.0 & -- & -- & 0 \\
\hline 1948 & 525.0 & -- & -- & 960.0 & 640.0 & -- & -- & 347.0 \\
\hline 1949 & 525.0 & -- & -- & 865.0 & 600.0 & -- & -- & 27.0 \\
\hline 1950 & 525.0 & -- & -- & 0 & 600.0 & -- & -- & 0 \\
\hline 1951 & $1,320.0$ & -- & -- & 750.0 & 575.0 & -- & -- & 79.0 \\
\hline 1952 & 525.0 & -- & -- & 314.0 & 560.0 & -- & -- & 480.0 \\
\hline 1953 & 780.0 & -- & -- & 532.0 & 560.0 & -- & -- & $1,347.0$ \\
\hline 1954 & 780.0 & -- & -- & 169.0 & 540.0 & -- & -- & 411.0 \\
\hline 1955 & 600.0 & -- & -- & 150.0 & 500.0 & -- & -- & $1,380.0$ \\
\hline 1956 & 780.0 & -- & -- & 357.0 & 480.0 & -- & -- & $1,099.0$ \\
\hline 1957 & 11.0 & -- & -- & 826.0 & 460.0 & -- & -- & $3,144.0$ \\
\hline 1958 & 500.0 & -- & -- & 343.0 & 436.0 & -- & -- & $1,078.0$ \\
\hline 1959 & 670.0 & -- & -- & 36.0 & 670.0 & -- & -- & $2,170.0$ \\
\hline 1960 & 0 & -- & -- & 343.0 & 0 & -- & -- & $2,170.0$ \\
\hline 1961 & $1,200.0$ & -. & -- & 343.0 & 0 & -- & -. & $1,088.0$ \\
\hline 1962 & $1,200.0$ & - & -- & 43.0 & 484.0 & -- & -- & $2,170.0$ \\
\hline 1963 & 0 & .- & -- & 400.0 & 0 & -- & -- & $1,035.0$ \\
\hline 1964 & $1,250.0$ & -- & -- & 746.0 & 508.0 & -- & -- & $2,980.0$ \\
\hline 1965 & $1,250.0$ & -- & -. & 343.0 & 0 & -- & -- & $3,670.0$ \\
\hline 1966 & $1,250.0$ & -- & -- & 250.0 & 0 & -- & -- & $3,670.0$ \\
\hline 1967 & 400.0 & -- & -- & 630.0 & 0 & -- & -- & $3,670.0$ \\
\hline 1968 & $1,300.0$ & -- & -- & 0 & 0 & -- & -- & $3,670.0$ \\
\hline 1969 & 800.0 & .- & -- & 20.0 & $2,150.0$ & .- & -. & $3,500.0$ \\
\hline 1970 & $1,300.0$ & -- & -- & 0 & $2,150.0$ & -- & -- & $2,400.0$ \\
\hline 1971 & 0 & -- & -- & 0 & 500.0 & -- & 27.5 & $2,000.0$ \\
\hline 1972 & 25.0 & -- & -- & 343.0 & 800.0 & -- & 27.5 & $4,053.0$ \\
\hline 1973 & 0 & -- & -- & 330.0 & 0 & -- & 27.5 & $3,800.0$ \\
\hline 1974 & 0 & .- & -- & 330.0 & 0 & .- & 27.5 & $3,800.0$ \\
\hline 1975 & 0 & -- & -- & 400.0 & 0 & -- & 27.5 & $2,710.0$ \\
\hline 1976 & 0 & 0 & 0 & 480.0 & 0 & 0 & 27.5 & $3,200.0$ \\
\hline 1977 & 0 & 0 & 0 & 0 & 0 & 0 & 27.5 & $3,450.0$ \\
\hline 1978 & 0 & 0 & 0 & 480.0 & 0 & 0 & 27.5 & $3,500.0$ \\
\hline 1979 & 0 & 0 & 0 & 480.0 & 0 & 0 & 27.5 & $2,500.0$ \\
\hline 1980 & 0 & 1.0 & 0 & 480.0 & $2,150.0$ & 0 & 27.5 & $2,450.0$ \\
\hline 1981 & 0 & 6.0 & 0 & 9.4 & 0 & -- & 27.5 & $3,500.0$ \\
\hline 1982 & 0 & 6.0 & 0 & 420.0 & 0 & 0 & 27.5 & $3,750.0$ \\
\hline 1983 & 0 & 6.0 & 0 & 420.0 & 0 & 0 & 27.5 & $2,300.0$ \\
\hline 1984 & 0 & 6.0 & 0 & 0 & 0 & 0 & 27.5 & $2,676.0$ \\
\hline 1985 & 0 & 6.0 & 0 & 480.0 & 0 & 5.0 & 27.5 & $2,683.0$ \\
\hline 1986 & 0 & 6.0 & 0 & 880.0 & 0 & 8.0 & 27.5 & $2,979.0$ \\
\hline 1987 & 0 & 6.0 & 0 & 0 & 300.0 & 8.0 & 27.5 & $2,989.0$ \\
\hline 1988 & 0 & 6.0 & 4.0 & 0 & 0 & 10.0 & 27.5 & $2,980.0$ \\
\hline 1989 & 0 & 6.0 & 0 & 0 & 80.0 & 8.0 & 27.5 & $2,670.0$ \\
\hline 1990 & 0 & 6.0 & 0 & 0 & 80.0 & 8.0 & 27.5 & $2,785.0$ \\
\hline 1991 & 0 & 6.0 & 0 & 0 & 380.0 & 7.0 & -- & $2,780.0$ \\
\hline 1992 & 0 & 6.0 & 0 & 0 & 0 & 8.0 & -- & 0 \\
\hline
\end{tabular}


Table 19. Water-use information for self-supplied water users in Antelope Valley by water-supply sources, 1946-92--Continued

\begin{tabular}{|c|c|c|c|c|c|c|c|c|c|}
\hline \multirow{2}{*}{ Year } & \multirow{2}{*}{$\begin{array}{c}\text { Rancho } \\
\text { Corona } \\
\text { Del Valle } \\
\text { Corporation } \\
\begin{array}{c}\text { Ground } \\
\text { water }\end{array}\end{array}$} & \multirow{2}{*}{$\begin{array}{c}\text { Rabinov, } \\
\text { David, } \\
\text { Medical } \\
\text { Doctor } \\
\begin{array}{c}\text { Surface } \\
\text { water }\end{array}\end{array}$} & \multirow{2}{*}{$\frac{\begin{array}{c}\text { Rancho } \\
\text { Vista } \\
\text { Development }\end{array}}{\text { Purchased }}$} & \multirow{2}{*}{ 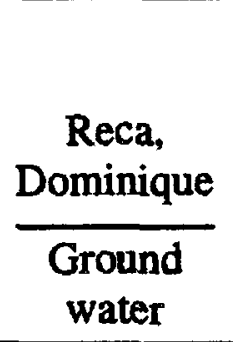 } & \multirow{2}{*}{$\begin{array}{c}\begin{array}{c}\text { Retlaw } \\
\text { Enterprises } \\
\text { Incorporated }\end{array} \\
\begin{array}{c}\text { Ground } \\
\text { water }\end{array}\end{array}$} & \multicolumn{3}{|c|}{ Ritter and Godde } & \multirow{2}{*}{$\begin{array}{c}\begin{array}{c}\text { Robbins, } \\
\text { David }\end{array} \\
\text { Purchased }\end{array}$} \\
\hline & & & & & & $\begin{array}{c}\text { Ground } \\
\text { water }\end{array}$ & $\begin{array}{c}\text { Pur- } \\
\text { chased }\end{array}$ & Total & \\
\hline 1946 & $\overline{0}$ & -- & -- & 0 & 0 & 0 & - & 0 & - \\
\hline 1947 & 0 & -- & -- & 0 & 0 & $1,767.0$ & -. & $1,767.0$ & -- \\
\hline 1948 & 560.0 & -- & -- & 0 & 0 & $2,027.0$ & -. & $2,027.0$ & -- \\
\hline 1949 & $1,344.0$ & -. & .- & 0 & 0 & $1,382.0$ & -- & $1,382.0$ & -- \\
\hline 1950 & 0 & -- & -- & 0 & 0 & $1,833.0$ & -- & $1,833.0$ & -- \\
\hline 1951 & 798.0 & .- & .- & 0 & 0 & $1,140.0$ & .. & $1,140.0$ & -- \\
\hline 1952 & 548.0 & -- & -- & 480.0 & 0 & $4,927.0$ & .. & $4,927.0$ & -. \\
\hline 1953 & 0 & .- & .- & 600.0 & 0 & $2,531.0$ & .- & $2,531.0$ & -- \\
\hline 1954 & 748.0 & -- & -- & 600.0 & 0 & $2,447.0$ & -. & $2,447.0$ & -- \\
\hline 1955 & 0 & -- & -- & 600.0 & 0 & $2,327.0$ & .- & $2,327.0$ & .- \\
\hline 1956 & $2,141.0$ & -- & .- & 600.0 & 0 & $2,349.0$ & .- & $2,349.0$ & -- \\
\hline 1957 & $3,118.0$ & -. & -- & $1,020.0$ & 0 & $4,345.0$ & -. & $4,345.0$ & -- \\
\hline 1958 & $2,726.0$ & -- & -- & 600.0 & 0 & $3,569.0$ & -- & $3,569.0$ & -- \\
\hline 1959 & $2,053.0$ & -- & .- & 600.0 & 0 & $3,676.0$ & -. & $3,676.0$ & -- \\
\hline 1960 & $2,528.0$ & -- & $\ldots$ & 600.0 & 0 & $4,399.0$ & -. & $4,399.0$ & -- \\
\hline 1961 & $2,854.0$ & 4.0 & -- & 600.0 & 0 & $6,477.0$ & -- & $6,477.0$ & -- \\
\hline 1962 & $5,278.0$ & 4.0 & -- & 600.0 & 0 & $5,391.0$ & -- & $5,391.0$ & - \\
\hline 1963 & $4,848.0$ & 4.0 & -- & 600.0 & 0 & $4,358.0$ & -- & $4,358.0$ & -. \\
\hline 1964 & $3,792.0$ & 4.0 & -- & 600.0 & 0 & $6,130.0$ & -- & $6,130.0$ & -. \\
\hline 1965 & 0 & 4.0 & -- & 600.0 & 0 & $7,136.0$ & -- & $7,136.0$ & -. \\
\hline 1966 & $1,676.0$ & 4.0 & -- & 800.0 & 0 & $6,582.0$ & -- & $6,582.0$ & -- \\
\hline 1967 & $5,278.0$ & 1.6 & -- & 800.0 & 0 & $6,167.0$ & .- & $6,167.0$ & -- \\
\hline 1968 & $5,808.0$ & 1.6 & -- & 850.0 & 0 & $11,234.0$ & -- & $11,234.0$ & -- \\
\hline 1969 & $4,523.0$ & 1.6 & -- & 850.0 & 0 & $11,582.0$ & -- & $11,582.0$ & -- \\
\hline 1970 & $6,025.0$ & 1.6 & -- & 850.0 & 0 & $12,124.0$ & -- & $12,124.0$ & -- \\
\hline 1971 & 0 & 1.6 & -- & 850.0 & 0 & $10,708.0$ & .. & $10,708.0$ & -- \\
\hline 1972 & 159.0 & 3.4 & $-\infty$ & 0 & 0 & $9,247.0$ & -- & $9,247.0$ & -- \\
\hline 1973 & 0 & 3.4 & -- & 850.0 & 0 & $10,069.0$ & .- & $10,069.0$ & -- \\
\hline 1974 & 0 & 3.4 & -- & 850.0 & 0 & $8,952.0$ & -- & $8,952.0$ & -- \\
\hline 1975 & 0 & -. & -- & 850.0 & 0 & $1,259.0$ & .- & $1,259.0$ & -- \\
\hline 1976 & 0 & .- & 0 & 850.0 & 0 & $11,067.0$ & 0 & $11,067.0$ & 0 \\
\hline 1977 & 0 & -. & 0 & 850.0 & 0 & $8,626.0$ & 914.0 & $9,540.0$ & 0 \\
\hline 1978 & 0 & -- & 0 & 850.0 & 0 & $13,094.0$ & $2,086.0$ & $15,180.0$ & 0 \\
\hline 1979 & 0 & -- & 0 & 850.0 & 0 & $2,460.6$ & $4,918.0$ & $7,378.6$ & 0 \\
\hline 1980 & 0 & 3.4 & 0 & 600.0 & 0 & $2,902.1$ & $1,876.0$ & $4,778.1$ & 0 \\
\hline 1981 & 0 & 3.4 & 0 & 600.0 & 0 & $4,778.0$ & $5,868.0$ & $10,646.0$ & 0 \\
\hline 1982 & 0 & 3.4 & 0 & 600.0 & $3,728.6$ & $2,610.0$ & $4,616.0$ & $7,226.0$ & 0 \\
\hline 1983 & 0 & 4.0 & 0 & 600.0 & 0 & $2,038.7$ & $2,881.0$ & $4,919.7$ & 0 \\
\hline 1984 & 0 & 4.0 & 0 & 600.0 & $6,602.0$ & 0 & $3,357.0$ & $3,357.0$ & 0 \\
\hline 1985 & 0 & 4.0 & 0 & 0 & $7,285.5$ & $2,333.2$ & $4,291.0$ & $6,624.2$ & 0 \\
\hline 1986 & 0 & 4.0 & 0 & 0 & $6,576.0$ & 0 & $2,894.0$ & $2,894.0$ & 0 \\
\hline 1987 & 0 & 4.0 & 155.0 & 0 & $7,306.0$ & $3,765.2$ & $3,645.0$ & $7,410.2$ & 0 \\
\hline 1988 & 0 & $\ldots$ & 225.0 & 0 & 0 & 0 & $2,939.0$ & $2,939.0$ & 0 \\
\hline 1989 & 0 & 4.0 & 11.0 & 0 & $6,914.0$ & $3,887.5$ & $2,911.0$ & $6,798.5$ & 0 \\
\hline 1990 & 0 & 4.0 & 0 & 0 & $6,904.0$ & $3,161.6$ & $3,843.0$ & $7,004.6$ & 0 \\
\hline 1991 & 0 & 4.0 & 0 & 0 & $6,914.0$ & $6,082.8$ & 0 & $6,082.8$ & 4.0 \\
\hline 1992 & 0 & -- & 0 & 0 & 0 & 0 & $1,124.0$ & $1,124.0$ & 8.0 \\
\hline
\end{tabular}


Table 19. Water-use information for self-supplied water users in Antelope Vailey by water-supply sources, 1946-92-Continued

\begin{tabular}{|c|c|c|c|c|c|c|c|c|}
\hline \multirow{2}{*}{ Year } & \multirow{2}{*}{$\begin{array}{l}\text { Robinson, } \\
\text { F. Willard, } \\
\text { and others } \\
\begin{array}{c}\text { Surface } \\
\text { water }\end{array}\end{array}$} & \multirow{2}{*}{$\begin{array}{c}\begin{array}{c}\text { Rosen, } \\
\text { Sandee }\end{array} \\
\text { Purchased }\end{array}$} & \multirow{2}{*}{$\begin{array}{c}\begin{array}{c}\text { RR } \\
\text { Ranch }\end{array} \\
\text { Purchased }\end{array}$} & \multirow{2}{*}{$\frac{S \& D}{\text { Purchased }}$} & \multirow{2}{*}{$\begin{array}{c}\begin{array}{c}\text { Sasland } \\
\text { Farms/ } \\
\text { Spivak-Brown }\end{array} \\
\begin{array}{c}\text { Ground } \\
\text { water }\end{array}\end{array}$} & \multirow{2}{*}{$\begin{array}{c}\begin{array}{c}\text { Schnaidt, } \\
\text { Harold }\end{array} \\
\text { Purchased }\end{array}$} & \multirow{2}{*}{$\begin{array}{c}\begin{array}{c}\text { Searcy, } \\
\text { Travis }\end{array} \\
\text { Purchased }\end{array}$} & \multirow{2}{*}{$\begin{array}{c}\begin{array}{c}\text { Seiki } \\
\text { Investment } \\
\text { Corporation }\end{array} \\
\begin{array}{c}\text { Ground } \\
\text { water }\end{array}\end{array}$} \\
\hline & & & & & & & & \\
\hline 1946 & 18.8 & -. & -- & -- & 0 & 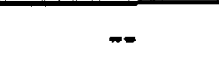 & -- & 0 \\
\hline 1947 & 18.8 & -- & -- & -- & 220.0 & .. & -- & 0 \\
\hline 1948 & 18.8 & -. & -. & -- & 220.0 & -- & -- & 150.0 \\
\hline 1949 & 18.8 & -- & -- & .- & 375.0 & -- & -- & 750.0 \\
\hline 1950 & 18.8 & -- & -. & -- & 375.0 & -- & -- & $1,500.0$ \\
\hline 1951 & 18.8 & -. & -- & -- & 375.0 & -- & -- & $1,500.0$ \\
\hline 1952 & 18.8 & .. & .- & .. & 324.0 & .- & -. & 611.0 \\
\hline 1953 & 18.8 & - & -- & -. & 375.0 & -- & - & 624.0 \\
\hline 1954 & 18.8 & -- & -- & -- & 375.0 & .- & -- & 135.0 \\
\hline 1955 & 18.8 . & -- & -- & -- & 375.0 & -- & -- & 240.0 \\
\hline 1956 & 18.8 & $\therefore$ & .- & .- & 375.0 & .- & .- & 240.0 \\
\hline 1957 & 18.8 & -- & -- & -. & 359.0 & -- & -. & 589.0 \\
\hline 1958 & 18.8 & -. & -- & -- & 630.0 & _- & -- & $2,163.0$ \\
\hline 1959 & 18.8 & -- & -- & .- & 315.0 & -- & -- & 30.0 \\
\hline 1960 & 18.8 & .. & .- & .. & 420.0 & .- & -. & 240.0 \\
\hline 1961 & 18.8 & - & - & -- & 350.0 & -- & -- & 765.0 \\
\hline 1962 & 18.8 & .- & .- & .- & 259.0 & .- & -- & 240.0 \\
\hline 1963 & 18.8 & -- & -- & .. & 450.0 & -- & -. & $2,312.0$ \\
\hline 1964 & 18.8 & .- & .- & .- & 375.0 & -. & -. & 64.0 \\
\hline 1965 & 18.8 & -- & -- & -- & 320.0 & -- & -- & 68.0 \\
\hline 1966 & 18.8 & .- & .- & .- & 360.0 & .- & -. & 0 \\
\hline 1967 & 18.8 & -- & -- & -- & 400.0 & -- & -- & 68.0 \\
\hline 1968 & 18.8 & .- & .- & .- & 600.0 & .- & .- & 68.0 \\
\hline 1969 & 18.8 & -. & -- & -- & 600.0 & -- & -. & $2,335.0$ \\
\hline 1970 & 18.8 & -- & -. & .- & 900.0 & -- & -- & 0 \\
\hline 1971 & 18.8 & -- & -- & -- & 900.0 & -. & -- & 0 \\
\hline 1972 & 18.8 & -- & -- & .- & 775.0 & -- & -- & 0 \\
\hline 1973 & 18.8 & -- & -- & -- & $1,200.0$ & -- & -- & 0 \\
\hline 1974 & 18.8 & -- & -- & - & $1,200.0$ & .. & -- & 0 \\
\hline 1975 & -. & -- & -- & -- & $1,200.0$ & .- & -- & 0 \\
\hline 1976 & -. & 0 & 0 & $2,575.0$ & $1,200.0$ & $1,655.0$ & 0 & 0 \\
\hline 1977 & -. & 0 & 169.0 & $1,514.0$ & 0 & $3,519.0$ & 0 & 0 \\
\hline 1978 & - & 0 & 839.0 & $1,906.0$ & 0 & $1,913.0$ & 0 & 0 \\
\hline 1979 & -. & 0 & $1,085.0$ & $2,561.0$ & 0 & $2,513.0$ & 0 & 0 \\
\hline 1980 & -. & 0 & $1,085.0$ & $2,148.0$ & 0 & $2,759.0$ & 0 & 0 \\
\hline 1981 & -- & 0 & $1,390.0$ & $2,316.0$ & 0 & $1,559.0$ & 0 & 0 \\
\hline 1982 & - & 0 & $1,192.0$ & $2,272.0$ & 0 & 47.0 & 0 & 0 \\
\hline 1983 & -- & 2.0 & $1,083.0$ & 0 & 0 & 11.0 & 0 & 0 \\
\hline 1984 & -- & 3.0 & $1,233.0$ & 0 & 0 & 28.0 & 0 & 0 \\
\hline 1985 & -- & 3.0 & $1,573.0$ & 0 & 300.0 & 31.0 & 3.0 & 0 \\
\hline 1986 & -- & 3.0 & $1,638.0$ & 0 & 0 & 59.0 & 7.0 & 0 \\
\hline 1987 & .- & 3.0 & 889.0 & 0 & 0 & 107.0 & 6.0 & 0 \\
\hline 1988 & 4.4 & 3.0 & 872.0 & 0 & 0 & 89.0 & 6.0 & 0 \\
\hline 1989 & 4.4 & 3.0 & $1,156.0$ & 0 & 0 & 117.0 & 7.0 & 0 \\
\hline 1990 & 4.4 & 3.0 & $1,188.0$ & 0 & 0 & 119.0 & 6.0 & 0 \\
\hline 1991 & -- & 6.0 & 0 & 0 & 0 & 80.0 & 6.0 & 0 \\
\hline 1992 & -- & 6.0 & 479.0 & 0 & 0 & 65.0 & 6.0 & 0 \\
\hline
\end{tabular}


Table 19. Water-use information for self-supplied water users in Antelope Valley by water-supply sources, 1946-92--Continued

\begin{tabular}{|c|c|c|c|c|c|c|c|c|}
\hline \multirow{2}{*}{ Year } & \multirow{2}{*}{$\begin{array}{c}\begin{array}{c}\text { Silva, } \\
\text { Don }\end{array} \\
\text { Purchased }\end{array}$} & \multirow{2}{*}{$\begin{array}{c}\begin{array}{c}\text { Simi, } \\
\text { Roy }\end{array} \\
\text { Purchased }\end{array}$} & \multirow{2}{*}{$\begin{array}{l}\text { Southern California } \\
\text { Edison Company } \\
\text { Ground water }\end{array}$} & \multirow{2}{*}{$\begin{array}{c}\begin{array}{c}\text { Stevens, } \\
\text { William E. }\end{array} \\
\begin{array}{c}\text { Ground } \\
\text { water }\end{array}\end{array}$} & \multirow{2}{*}{$\frac{\text { Stoner }}{\text { Purchased }}$} & \multirow{2}{*}{$\begin{array}{c}\text { Sundown Ranch } \\
\text { Company }\end{array}$} & \multirow{2}{*}{$\frac{\begin{array}{c}\text { Tapia } \\
\text { Brothers }\end{array}}{\text { Purchased }}$} & \multirow{2}{*}{$\begin{array}{c}\begin{array}{c}\text { Tauton, } \\
\text { Windsor } \mathrm{P} .\end{array} \\
\begin{array}{c}\text { Ground } \\
\text { water }\end{array}\end{array}$} \\
\hline & & & & & & & & \\
\hline 1946 & -- & - & 0 & 0 & -- & $\overline{0}$ & -- & 0 \\
\hline 1947 & -- & -- & 0 & 0 & -- & 0 & -- & 0 \\
\hline 1948 & -- & -- & 0 & 0 & -- & 4.0 & -- & 0 \\
\hline 1949 & -- & -- & 0 & 569.0 & - & 0 & -- & 0 \\
\hline 1950 & .- & -- & 0 & 0 & -- & 0 & -- & 0 \\
\hline 1951 & .. & -- & 0 & 0 & -- & 226.0 & -- & 0 \\
\hline 1952 & -. & -- & 0 & 0 & -- & 0 & $\ldots$ & 0 \\
\hline 1953 & -- & -- & 0 & 244.0 & -- & 0 & -. & 0 \\
\hline 1954 & -- & -- & 0 & 235.0 & -- & 0 & -- & 0 \\
\hline 1955 & -- & -- & 0 & 240.0 & -- & 0 & -- & 0 \\
\hline 1956 & -- & -- & 5.0 & $1,176.0$ & -- & 20.0 & -- & 0 \\
\hline 1957 & - & -- & 9.0 & 454.0 & -- & 0 & -- & 0 \\
\hline 1958 & -- & -- & 540.0 & 516.0 & -- & 149.0 & -- & 0 \\
\hline 1959 & -- & -- & 0 & 502.0 & -- & 408.0 & -- & 0 \\
\hline 1960 & - & -- & 9.0 & 473.0 & -- & 399.0 & -- & 0 \\
\hline 1961 & -- & -- & 8.0 & 540.0 & -- & 943.0 & -- & 0 \\
\hline 1962 & -- & -- & 660.0 & 557.0 & -- & 132.0 & -- & 0 \\
\hline 1963 & -- & -- & 856.0 & 511.0 & -- & 77.0 & -- & 0 \\
\hline 1964 & -- & -- & 7.0 & 543.0 & -- & 78.0 & -- & 0 \\
\hline 1965 & -- & -- & 6.0 & 520.0 & -- & 501.0 & - & 0 \\
\hline 1966 & -- & -- & 89.0 & 505.0 & -- & 956.0 & -- & 0 \\
\hline 1967 & -- & -- & 13.0 & 515.0 & -- & 911.0 & -- & 0 \\
\hline 1968 & -- & -- & 7.0 & 510.0 & -- & 0 & -- & 0 \\
\hline 1969 & -- & -. & 575.0 & 370.0 & -- & 128.0 & -- & 0 \\
\hline 1970 & -- & -- & 13.0 & 480.0 & -- & 364.0 & -- & 0 \\
\hline 1971 & -- & -- & 17.0 & 528.0 & -- & 0 & -- & 0 \\
\hline 1972 & -- & -- & 30.0 & 0 & -- & 0 & -- & 0 \\
\hline 1973 & -- & -- & 15.0 & 0 & .- & 0 & -- & 0 \\
\hline 1974 & - & -- & 9.0 & 0 & -- & 0 & -- & 0 \\
\hline 1975 & -- & .- & 11.0 & 648.0 & .- & 0 & -- & 0 \\
\hline 1976 & 0 & 0 & 10.0 & 823.0 & 0 & 0 & 0 & 0 \\
\hline 1977 & 0 & 0 & 11.0 & 989.0 & 0 & 0 & 0 & 0 \\
\hline 1978 & 0 & 0 & 11.0 & 936.0 & 136.0 & 0 & $1,010.0$ & 0 \\
\hline 1979 & 0 & 59.0 & 0 & 950.0 & $1,824.0$ & 0 & 701.0 & 0 \\
\hline 1980 & 0 & 650.0 & 9.2 & 0 & $2,150.0$ & 0 & $2,041.0$ & .3 \\
\hline 1981 & 0 & $1,154.0$ & 9.5 & 0 & $1,961.0$ & 0 & $2,423.0$ & .3 \\
\hline 1982 & 0 & 989.0 & 9.0 & 0 & $1,591.0$ & 0 & $2,521.0$ & .3 \\
\hline 1983 & 0 & 787.0 & 7.9 & 0 & $2,438.0$ & 0 & $1,967.0$ & .3 \\
\hline 1984 & 0 & $1,372.0$ & 16.5 & 0 & 0 & 0 & $1,487.0$ & 1.8 \\
\hline 1985 & 0 & $1,093.0$ & 2.7 & 0 & 0 & 0 & $2,183.0$ & 1.8 \\
\hline 1986 & 0 & 955.0 & 8.2 & 0 & 0 & 0 & $1,405.0$ & 1.8 \\
\hline 1987 & 0 & $1,188.0$ & 8.2 & 0 & 0 & 0 & $1,573.0$ & 1.8 \\
\hline 1988 & 2.0 & 994.0 & 0 & 0 & 0 & 0 & 599.0 & 1.8 \\
\hline 1989 & 11.0 & $1,150.0$ & 0 & 0 & 0 & 0 & $1,707.0$ & 0 \\
\hline 1990 & 12.0 & 925.0 & .1 & 0 & 0 & .1 & $1,294.0$ & 0 \\
\hline 1991 & 9.0 & 0 & 20.0 & 0 & 0 & 0 & 0 & 0 \\
\hline 1992 & 10 & 0 & 0 & 0 & 0 & 0 & 402.0 & 0 \\
\hline
\end{tabular}


Table 19. Water-use information for self-supplied water users in Antelope Valley by water-supply sources, 1946-92--Continued

\begin{tabular}{|c|c|c|c|c|c|c|c|c|c|c|c|}
\hline \multirow{2}{*}{ Year } & \multicolumn{3}{|c|}{$\begin{array}{l}\text { Tejon } \\
\text { Ranch }\end{array}$} & \multirow{2}{*}{$\begin{array}{c}\text { Thompson, } \\
\text { Jerome H. } \\
\begin{array}{c}\text { Surface } \\
\text { water }\end{array}\end{array}$} & \multirow{2}{*}{ 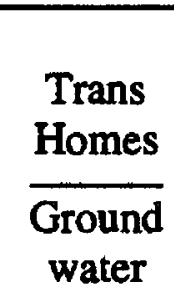 } & \multirow{2}{*}{$\begin{array}{c}\begin{array}{c}\text { Traweek, } \\
\text { S.V. }\end{array} \\
\begin{array}{c}\text { Ground } \\
\text { water }\end{array}\end{array}$} & \multicolumn{3}{|c|}{$\begin{array}{l}\text { United States } \\
\text { Angeles } \\
\text { National Forest }\end{array}$} & \multirow{2}{*}{$\begin{array}{c}\begin{array}{c}\text { Union } \\
\text { Wilshire } \\
\text { Incorporated }\end{array} \\
\begin{array}{c}\text { Ground } \\
\text { water }\end{array}\end{array}$} & \multirow{2}{*}{$\frac{\text { Vandereyk }}{\text { Purchased }}$} \\
\hline & $\begin{array}{l}\text { Ground } \\
\text { water }\end{array}$ & $\begin{array}{c}\text { Pur- } \\
\text { chased }\end{array}$ & Total & & & & $\begin{array}{c}\text { Ground } \\
\text { water }\end{array}$ & $\begin{array}{c}\text { Surface } \\
\text { water }\end{array}$ & Total & & \\
\hline 1946 & -- & $\overline{--}$ & 0 & - & 0 & 0 & 0 & $\overline{--}$ & 0 & 0 & -- \\
\hline 1947 & .- & -. & 0 & .- & 0 & 0 & 0 & _- & 0 & 0 & -- \\
\hline 1948 & -. & -. & 0 & -- & $4,871.0$ & 0 & 0 & -- & 0 & 0 & -- \\
\hline 1949 & -- & $\cdots$ & 0 & -- & 0 & 765.0 & 0 & .. & 0 & 105.0 & -- \\
\hline 1950 & -. & -- & 0 & -. & 0 & 0 & 0 & -- & 0 & 0 & -- \\
\hline 1951 & .- & .- & 0 & .- & 0 & 480.0 & 0 & -- & 0 & 948.0 & -. \\
\hline 1952 & -- & -- & 0 & -- & 13.0 & 375.0 & 0 & 4.5 & 4.5 & 275.0 & -- \\
\hline 1953 & .. & .- & 0 & .- & 590.0 & 420.0 & 0 & 4.5 & 4.5 & $1,200.0$ & -. \\
\hline 1954. & -- & -- & 0 & -- & 580.0 & $1,319.0$ & 0 & 4.5 & 4.5 & $1,724.0$ & -. \\
\hline 1955 & .- & .- & 0 & .- & 560.0 & 560.0 & 0 & 4.5 & 4.5 & 979.0 & -- \\
\hline 1956 & -- & -- & 0 & - & 540.0 & 126.0 & 0 & 4.5 & 4.5 & 686.0 & -- \\
\hline 1957 & .- & .- & 0 & ..- & 436.0 & 565.0 & 0 & 4.5 & 4.5 & 444.0 & -- \\
\hline 1958 & -- & -- & 0 & -- & 0 & 449.0 & 0 & 4.5 & 4.5 & 762.0 & -- \\
\hline 1959 & -- & -- & 0 & -- & 0 & 390.0 & 0 & 4.5 & 4.5 & $1,276.0$ & -- \\
\hline 1960 & -- & -- & 0 & -- & 0 & 390.0 & 0 & 4.5 & 4.5 & 846.0 & -- \\
\hline 1961 & -- & -- & 0 & 3.1 & 478.0 & 53.0 & 0 & 4.5 & 4.5 & 632.0. & -- \\
\hline 1962 & -- & -- & 0 & 3.1 & 0 & 13.0 & 0 & 4.5 & 4.5 & 813.0 & -- \\
\hline 1963 & -- & .- & 0 & 3.1 & 0 & $1,074.0$ & 0 & 4.5 & 4.5 & 820.0 & -- \\
\hline 1964 & -- & -- & 0 & 3.1 & 0 & 525.0 & 0 & 4.5 & 4.5 & 693.0 & -- \\
\hline 1965 & -- & -. & 0 & 3.1 & 0 & 525.0 & 0 & 4.5 & 4.5 & $1,273.0$ & -- \\
\hline 1966 & -- & -- & 0 & 3.1 & 0 & 125.0 & 0 & 4.5 & 4.5 & $1,183.0$ & -- \\
\hline 1967 & -- & -- & 0 & 3.1 & 0 & 58.0 & 0 & 4.5 & 4.5 & $1,139.0$ & -- \\
\hline 1968 & -- & -- & 0 & 3.1 & 0 & $1,397.0$ & 0 & 4.5 & 4.5 & $1,594.0$ & -- \\
\hline 1969 & -- & -- & 0 & 3.1 & 0 & 650.0 & 0 & 4.5 & 4.5 & 569.0 & -. \\
\hline 1970 & -- & -- & 0 & 3.1 & 0 & 520.0 & 0 & 4.5 & 4.5 & $1,602.0$ & -- \\
\hline 1971 & -- & -- & 0 & 3.1 & 0 & 515.0 & 0 & 4.5 & 4.5 & $1,505.0$ & -- \\
\hline 1972 & .. & -- & 0 & 3.1 & 0 & 0 & 24.3 & 4.5 & 28.8 & 973.0 & -- \\
\hline 1973 & -- & -- & 0 & 3.1 & 0 & 500.0 & 21.2 & 4.5 & 25.7 & $1,791.0$ & -- \\
\hline 1974 & -- & -- & 0 & 3.1 & 0 & 500.0 & 17.5 & 4.5 & 22.0 & $1,620.0$ & -- \\
\hline 1975 & -- & -- & 0 & 3.1 & 0 & 500.0 & 21.0 & 4.5 & 25.5 & $1,229.0$ & -- \\
\hline 1976 & -- & $11,677.0$ & $11,677.0$ & 3.1 & 0 & 500.0 & 20.9 & 4.5 & 25.4 & $1,774.0$ & 457.0 \\
\hline 1977 & -- & $9,268.0$ & $9,268.0$ & 3.1 & 0 & 500.0 & 32.2 & 4.5 & 36.7 & 0 & 953.0 \\
\hline 1978 & -- & $5,690.0$ & $5,690.0$ & 3.1 & 0 & 500.0 & 28.9 & 4.5 & 33.4 & 0 & 893.0 \\
\hline 1979 & -- & $5,970.0$ & $5,970.0$ & 3.1 & 0 & 450.0 & 37.9 & 0.8 & 38.7 & 0 & $1,100.0$ \\
\hline 1980 & -. & $8,860.0$ & $8,860.0$ & 3.1 & 0 & 450.0 & 25.7 & 0.8 & 26.5 & 0 & $1,093.0$ \\
\hline 1981 & -- & $8,158.0$ & $8,158.0$ & 3.1 & 0 & 450.0 & 42.1 & 0.8 & 42.9 & 0 & 0 \\
\hline 1982 & -- & $3,714.0$ & $3,714.0$ & 3.1 & 0 & 450.0 & 24.0 & 4.5 & 28.5 & 0 & 0 \\
\hline 1983 & -- & 55.0 & 55.0 & 3.1 & 0 & 450.0 & 43.1 & 4.5 & 47.6 & 0 & 0 \\
\hline 1984 & -- & 93.0 & 93.0 & 3.1 & 0 & 450.0 & 0 & 4.5 & 4.5 & 0 & 0 \\
\hline 1985 & -- & 8.0 & 8.0 & 3.1 & 0 & 0 & 105.0 & 3.6 & 108.6 & 0 & 0 \\
\hline 1986 & -- & 6.0 & 6.0 & 3.1 & 0 & 0 & 0 & 3.6 & 3.6 & 0 & 0 \\
\hline 1987 & -- & 0 & 0 & 3.1 & 0 & 0 & 44.0 & 3.6 & 47.6 & 0 & 0 \\
\hline 1988 & -- & 0 & 0 & 3.1 & 0 & 0 & 41.0 & 20.6 & 61.6 & 0 & 0 \\
\hline 1989 & -. & 0 & 0 & 3.1 & 0 & 0 & 95.0 & 20.6 & 115.6 & 0 & 0 \\
\hline 1990 & -- & 0 & 0 & 3.1 & 0 & 0 & 0 & 20.6 & 20.6 & 0 & 0 \\
\hline 1991 & $9,728.0$ & $-3,265.0$ & $6,463.0$ & - & 0 & 0 & 127.3 & - & 127.3 & 0 & 0 \\
\hline 1992 & $1,006.0$ & 0 & $1,006.0$ & -. & 0 & 0 & 0 & -. & 0 & 0 & 0 \\
\hline
\end{tabular}


Table 19. Water-use information for self-supplied water users in Antelope Valley by water-supply sources, 1946-92-Continued

\begin{tabular}{|c|c|c|c|c|c|c|c|c|}
\hline \multirow{2}{*}{ Year } & \multirow{2}{*}{$\begin{array}{l}\begin{array}{c}\text { Vaught, } \\
\text { Amelia }\end{array} \\
\text { Purchased }\end{array}$} & \multirow{2}{*}{$\begin{array}{c}\text { Wade, } \\
\frac{\text { Thomas H. }}{\text { Ground }} \\
\text { water }\end{array}$} & \multirow{2}{*}{$\frac{\begin{array}{c}\text { Ward, J.W.I } \\
\text { Lyman Champlain }\end{array}}{\text { Ground water }}$} & \multirow{2}{*}{$\frac{\text { Weaver }}{\text { Purchased }}$} & \multirow{2}{*}{$\begin{array}{l}\text { White, J.F. JR., } \\
\frac{\text { H.B. and D.B. }}{c} \\
\begin{array}{c}\text { Surface } \\
\text { water }\end{array}\end{array}$} & \multirow{2}{*}{$\begin{array}{c}\begin{array}{c}\text { White, James B. } \\
\text { or Dee Ann }\end{array} \\
\begin{array}{c}\text { Ground } \\
\text { water }\end{array}\end{array}$} & \multirow{2}{*}{$\begin{array}{c}\begin{array}{c}\text { White, } \\
\text { Michael G. }\end{array} \\
\begin{array}{c}\text { Ground } \\
\text { water }\end{array}\end{array}$} & \multirow{2}{*}{$\begin{array}{c}\begin{array}{c}\text { White, } \\
\text { Richard A. }\end{array} \\
\begin{array}{c}\text { Ground } \\
\text { water }\end{array}\end{array}$} \\
\hline & & & & & & & & \\
\hline 1946 & -- & 0 & 0 & -. & 0.8 & 0 & 0 & 0 \\
\hline 1947 & -- & 0 & 280.0 & -- & .8 & 0 & 0 & 0 \\
\hline 1948 & -- & 0 & 280.0 & -- & .8 & 0 & 0 & 0 \\
\hline 1949 & -- & 0 & 30.0 & -- & .8 & 0 & 0 & 0 \\
\hline 1950 & -- & 0 & 280.0 & -- & .8 & 0 & 0 & 0 \\
\hline 1951 & -- & 0 & 322.0 & -- & .8 & 0 & 0 & 0 \\
\hline 1952 & -- & 0 & 370.0 & -- & .8 & 0 & 0 & 0 \\
\hline 1953 & -- & 0 & 280.0 & -- & .8 & 0 & 0 & 0 \\
\hline 1954 & -- & 0 & 49.0 & -- & .8 & 0 & 0 & 0 \\
\hline 1955 & -- & 0 & 280.0 & -- & .8 & 0 & 0 & 0 \\
\hline 1956 & -- & 0 & 280.0 & -- & .8 & 0 & 0 & 0 \\
\hline 1957 & -- & 0 & 132.0 & -- & .8 & 0 & 0 & 0 \\
\hline 1958 & -- & 0 & 0 & -- & .8 & 0 & 0 & 0 \\
\hline 1959 & -- & 0 & 1.0 & -- & .8 & 0 & 0 & 0 \\
\hline 1960 & -- & 0 & 2.0 & -- & .8 & 0 & 0 & 0 \\
\hline 1961 & .- & 0 & 138.0 & -- & 1.0 & 0 & 0 & 0 \\
\hline 1962 & -- & 0 & 2.0 & -. & 1.0 & 0 & 0 & 0 \\
\hline 1963 & -- & 0 & 1.0 & -- & 1.0 & 0 & 0 & 0 \\
\hline 1964 & -- & 0 & 0 & -- & .8 & 0 & 0 & 0 \\
\hline 1965 & -- & 0 & 1.0 & -- & .8 & 0 & 0 & 0 \\
\hline 1966 & -- & 0 & 502.0 & -- & .8 & 0 & 0 & 0 \\
\hline 1967 & -- & 0 & 1.0 & -- & 1.1 & 0 & 0 & 0 \\
\hline 1968 & -- & 0 & 1.0 & -- & 1.1 & 0 & 0 & 0 \\
\hline 1969 & -- & 0 & 1.0 & -- & 1.1 & 0 & 0 & 0 \\
\hline 1970 & -- & 0 & 1.0 & -- & 53.8 & 0 & 0 & 0 \\
\hline 1971 & -- & 0 & 1.0 & -- & 53.8 & 0 & 0 & 0 \\
\hline 1972 & -- & 0 & 246.0 & -- & 53.8 & 0 & 0 & 0 \\
\hline 1973 & -- & 0 & 1.0 & -- & 53.8 & 0 & 0 & 0 \\
\hline 1974 & -- & 0 & 1.0 & .. & 53.8 & 0 & 0 & 0 \\
\hline 1975 & -- & 0 & 0 & -. & 53.8 & 0 & 0 & 0 \\
\hline 1976 & 0 & 0 & 0 & 0 & .8 & 0 & 0 & 0 \\
\hline 1977 & 0 & 0 & 0 & 1.0 & .8 & 0 & 0 & 0 \\
\hline 1978 & 0 & 0 & 0 & 45.0 & .8 & 0 & 0 & 0 \\
\hline 1979 & 0 & 0 & 0 & 859.0 & 2.1 & 0 & 0 & 0 \\
\hline 1980 & 0 & 0 & 0 & 354.0 & 2.1 & 0 & 0 & 0 \\
\hline 1981 & 0 & 0 & 0 & 835.0 & 2.1 & 0 & 0 & 0 \\
\hline 1982 & 0 & 0 & 0 & 1.0 & .8 & 0 & 0 & 0 \\
\hline 1983 & 0 & 0 & 0 & 1.0 & .8 & 0 & 0 & 0 \\
\hline 1984 & 0 & 0 & 0 & 0 & .8 & 0 & 0 & 0 \\
\hline 1985 & 0 & 0 & 0 & 0 & .8 & 0 & 0 & 1.2 \\
\hline 1986 & 5.0 & 0 & 0 & 0 & .8 & .2 & 0 & 1.2 \\
\hline 1987 & 6.0 & 0 & 0 & 0 & .8 & .2 & .1 & 1.3 \\
\hline 1988 & 7.0 & 0 & 0 & 0 & .8 & .2 & .1 & 1.4 \\
\hline 1989 & 7.0 & 1.8 & 0 & 0 & .8 & 24.0 & 0 & 0 \\
\hline 1990 & 6.0 & 0 & 0 & 0 & .8 & 14.0 & 0 & 2.2 \\
\hline 1991 & 6.0 & 3.3 & 0 & 0 & .8 & 43.0 & 0 & 1.1 \\
\hline 1992 & 6.0 & 0 & 0 & 0 & .8 & 0 & 0 & 0 \\
\hline
\end{tabular}


Table 19. Water-use information for self-supplled water users in Antelope Valley by water-supply sources, 1946-92--Continued

\begin{tabular}{|c|c|c|c|c|c|c|c|}
\hline \multirow{2}{*}{ Year } & \multirow{2}{*}{$\begin{array}{c}\text { Williams, } \\
\text { Claude } \\
\text { Ground water }\end{array}$} & \multirow{2}{*}{$\begin{array}{c}\begin{array}{c}\text { Zamrzla, } \\
\text { Johnny }\end{array} \\
\text { Ground water }\end{array}$} & \multirow{2}{*}{$\begin{array}{c}\begin{array}{c}\text { Total self- } \\
\text { supplied water }\end{array} \\
\text { Ground water }\end{array}$} & \multirow{2}{*}{$\begin{array}{c}\begin{array}{c}\text { Total self- } \\
\text { supplied water }\end{array} \\
\text { Surface water }\end{array}$} & \multirow{2}{*}{$\frac{\text { Total }}{\text { Purchased }}$} & \multirow{2}{*}{$\begin{array}{l}\text { Grand } \\
\text { total }\end{array}$} & \multirow{2}{*}{$\begin{array}{l}\text { No. of users } \\
\text { reporting } \\
\text { (of } 156 \text { ) }\end{array}$} \\
\hline & & & & & & & \\
\hline 1946 & 0 & 0 & 230.0 & 104.6 & 0 & 334.6 & 8 \\
\hline 1947 & 569.0 & 240.0 & $75,883.0$ & 104.6 & 0 & $75,987.6$ & 33 \\
\hline 1948 & $2,240.0$ & 147.0 & $132,018.0$ & 466.9 & 0 & $132,484.9$ & 50 \\
\hline 1949 & 569.0 & 90.0 & $135,170.0$ & $3,874.1$ & 0 & $139,044.1$ & 55 \\
\hline 1950 & 569.0 & 240.0 & $113,682.0$ & $3,874.0$ & 0 & $117,556.0$ & 45 \\
\hline 1951 & 896.0 & 240.0 & $160,243.0$ & $3,874.0$ & 0 & $164,117.0$ & 60 \\
\hline 1952 & 86.0 & 240.0 & $207,656.0$ & $1,991.4$ & 0 & $209,647.4$ & 64 \\
\hline 1953 & 355.0 & 116.0 & $186,790.0$ & $1,714.6$ & 0 & $188,504.6$ & 71 \\
\hline 1954 & $1,089.0$ & 101.0 & $207,773.0$ & $2,514.6$ & 0 & $210,287.6$ & 71 \\
\hline 1955 & 569.0 & 240.0 & $216,317.0$ & $2,513.5$ & 0 & $218,830.5$ & 68 \\
\hline 1956 & 569.0 & 308.0 & $251,767.0$ & $2,913.5$ & 0 & $254,680.5$ & 78 \\
\hline 1957 & $1,371.0$ & 172.0 & $208,783.0$ & $3,502.3$ & 0 & $212,285.3$ & 80 \\
\hline 1958 & 665.0 & 205.0 & $196,215.0$ & $3,492.6$ & 0 & $199,707.6$ & 77 \\
\hline 1959 & $2,000.0$ & 132.0 & $213,603.0$ & $3,592.6$ & 0 & $21,195.6$ & 74 \\
\hline 1960 & 569.0 & 360.0 & $178,047.0$ & $3,444.3$ & 0 & $181,491.3$ & 77 \\
\hline 1961 & 77.0 & 650.0 & $193,604.0$ & $3,701.6$ & 0 & $197,305.6$ & 79 \\
\hline 1962 & $1,611.0$ & 125.0 & $209,507.0$ & $3,504.9$ & 0 & $213,011.9$ & 79 \\
\hline 1963 & 784.0 & 96.0 & $175,401.0$ & $4,972.4$ & 0 & $180,373.4$ & 80 \\
\hline 1964 & $1,279.0$ & 112.0 & $174,711.0$ & $5,652.2$ & 0 & $180,363.2$ & 84 \\
\hline 1965 & 0 & 240.0 & $118,236.0$ & $5,664.0^{\circ}$ & 0 & $123,900.0$ & 75 \\
\hline 1966 & 829.0 & 0 & $171,707.0$ & $4,052.4$ & 0 & $175,759.4$ & 80 \\
\hline 1967 & 829.0 & 675.0 & $169,733.0$ & $5,564.5$ & 0 & $175,297.5$ & 82 \\
\hline 1968 & 93.0 & 280.0 & $188,713.0$ & $6,961.0$ & 0 & $195,674.0$ & 83 \\
\hline 1969 & $2,196.0$ & 280.0 & $147,575.0$ & $6,962.2$ & 0 & $154,537.2$ & 85 \\
\hline 1970 & 829.0 & 280.0 & $96,647.0$ & $7,014.8$ & 0 & $103,661.8$ & 81 \\
\hline 1971 & 829.0 & 0 & $80,973: 0$ & $7,314.4$ & 0 & $88,287.4$ & 75 \\
\hline 1972 & 0 & 0 & $51,874.3$ & $7,318.0$ & 0 & $59,192.3$ & 58 \\
\hline 1973 & 829.0 & 0 & $66,762.2$ & $7,458.2$ & 0 & $74,220.4$ & 72 \\
\hline 1974 & 829.0 & 280.0 & $62,406.5$ & $7,499.2$ & 0 & $69,905.7$ & 72 \\
\hline 1975 & 0 & 280.0 & $56,332.0$ & $7,002.2$ & 0 & $63,334.2$ & 69 \\
\hline 1976 & 0 & 280.0 & $70,101.9$ & $6,581.6$ & $27,295.0$ & $103,978.5$ & 72 \\
\hline 1977 & 0 & 0 & $65,481.0$ & $6,581.6$ & $32,646.0$ & $104,708.6$ & 84 \\
\hline 1978 & 0 & 0 & $57,428.7$ & $6,603.2$ & $37,615.0$ & $101,646.9$ & 84 \\
\hline 1979 & 0 & 0 & $45,098.0$ & $2,064.6$ & $51,166.0$ & $98,328.6$ & 77 \\
\hline 1980 & 0 & 0 & $36,922.7$ & $4,217.7$ & $55,428.0$ & $96,568.4$ & 85 \\
\hline 1981 & 0 & 0 & $35,721.7$ & $4,616.1$ & $64,570.0$ & $104,907.8$ & 87 \\
\hline 1982 & 0 & 0 & $35,772.7$ & $4,891.7$ & $39,627.0$ & $80,291.4$ & 81 \\
\hline 1983 & 0 & 0 & $28,588.0$ & $3,506.3$ & $23,922.0$ & $56,016.3$ & 78 \\
\hline 1984 & 0 & 0 & $32,163.4$ & $3,833.0$ & $18,699.0$ & $54,695.4$ & 74 \\
\hline 1985 & 0 & 0 & $36,504.5$ & $3,956.7$ & $22,136.0$ & $62,597.2$ & 77 \\
\hline 1986 & 0 & 0 & $34,079.0$ & $3,337.7$ & $15,040.0$ & $52,456.7$ & 76 \\
\hline 1987 & 0 & 0 & $38,305.7$ & $2,744.4$ & $14,693.0$ & $55,743.1$ & 78 \\
\hline 1988 & 0 & 0 & $9,083.3$ & $3,165.7$ & $15,274.0$ & $27,523.0$ & 67 \\
\hline 1989 & 0 & 0 & $27,920.0$ & $3,127.1$ & $17,108.0$ & $48,155.1$ & 72 \\
\hline 1990 & 0 & 0 & $27,306.4$ & $2,119.5$ & $15,499.0$ & $44,924.9$ & 70 \\
\hline 1991 & 0 & 0 & $46,535.3$ & $1,633.3$ & $2,769.0$ & $50,937.6$ & 64 \\
\hline 1992 & 0 & 0 & $1,006.0$ & 889.3 & $3,823.0$ & $5,718.3$ & 32 \\
\hline
\end{tabular}

